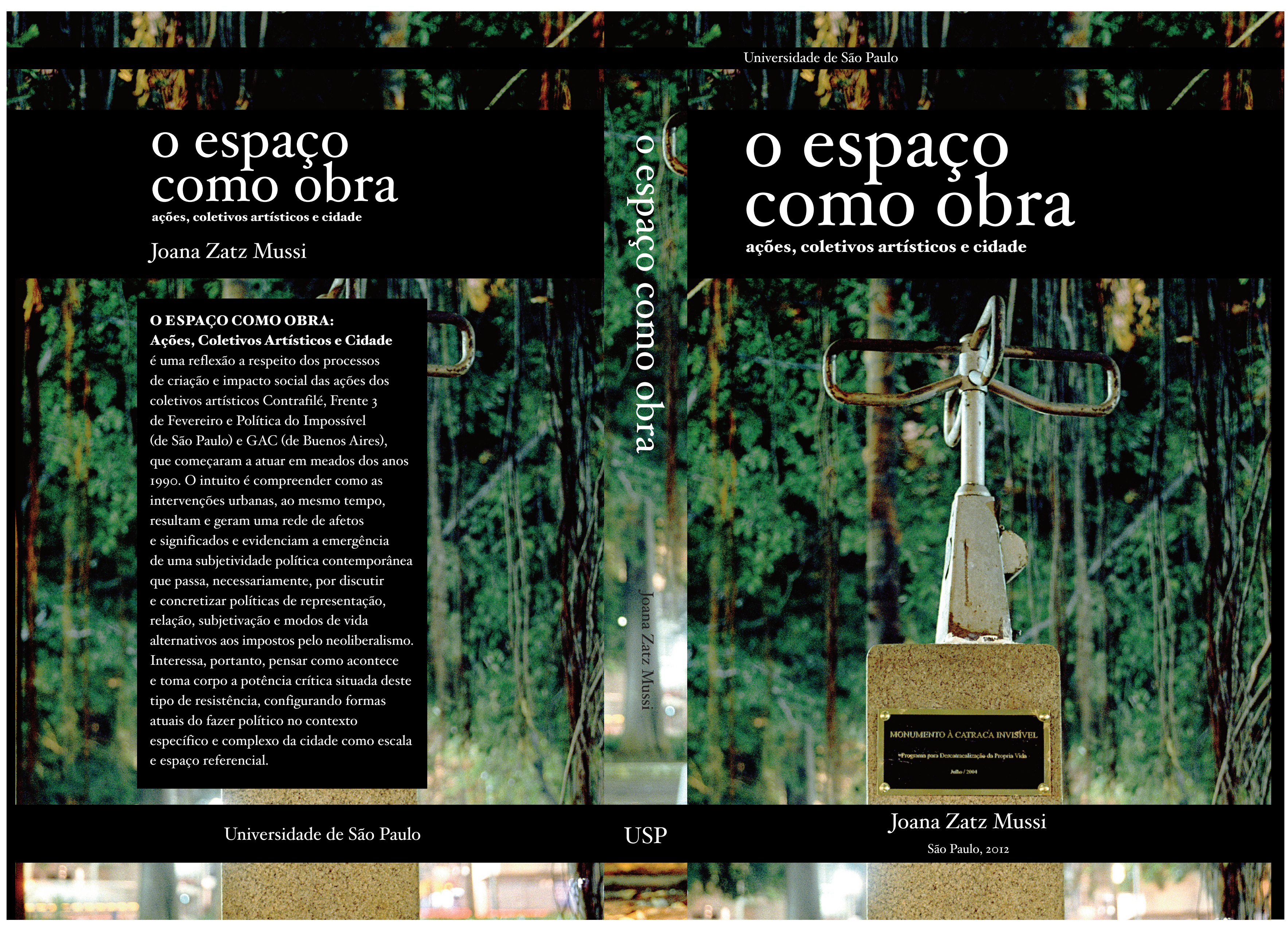


PROJETO JO 08:Layout 1 7/25/12 11:43 AM Pagse 2 


\section{O ESPAÇO COMO OBRA}

ações, coletivos artísticos e cidade

São Paulo

2012

Joana Zatz Mussi

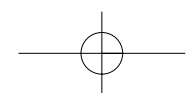


PROJETO JO 08:Layout 1 7/25/12 11:43 AM Pagse 4 


\section{O ESPAÇO COMO OBRA}

ações, coletivos artísticos e cidade

Dissertação apresentada à Faculdade de Arquitetura e Urbanismo da Universidade de São Paulo para obtenção do título de Mestre em Arquitetura e Urbanismo Área de Concentração: Projeto, Espaço e Cultura

Orientadora: Profa. Dra. Vera Pallamin

São Paulo

$2 \mathrm{OI} 2$ 
Mussi, Joana Zatz

M989 O espaço como obra : ações, coletivos artísticos e cidade / Joana Zatz Mussi. - São

Paulo, 2012.

326 p. : il.

Dissertação (Mestrado - Área de Concentração: Projeto, Espaço e Cultura FAUUSP.

Orientadora: Vera Pallamin

1. Arte pública 2. Performance 3. Artes (Aspectos políticos, culturais, urbanísticos, sociais) América Latina 4. Artes - Século 21 5. Coletivos artísticos I.Título

CDU 7.067.3

AUTORIZO A REPRODUÇÃO E DIVULGAÇÃO TOTAL OU PARCIAL DESTE TRABALHO, POR QUALQUER MEIO CONVENCIONAL OU ELETRÔNICO, PARA FINS DE ESTUDO E PESQUISA, DESDE QUE CITADA A FONTE.

E-MAIL: joanazatzmussi@gmail.com 


\section{Agradecimentos}

Essa dissertação é resultado de doze anos de trabalho junto a diversas pessoas e coletivos, brasileiros e estrangeiros, implicados em refletir e agir eticamente para que a vida adquira sentidos compartilhados, mais justos e interessantes. Não tenho nem palavras para agradecer a tantas pessoas e grupos com os quais fiz tantas coisas, conversei tanto e que me fizeram entender as formas e forças do mundo, em muitos aspectos, mais profundamente: Contrafilé, GAC, PI, Frente 3 de Fevereiro, Bijari, Rodrigo Araújo, Casa de Cultura Tainã e Rede Mocambos, Brian Holmes, Colectivo Situaciones, Er roristas, Marcelo Expósito, WHW, Zanny Beg, Keg de Souza, Cobaia, What's to be Done?, Coringa, Gavin Adams (que também fez o Abstract "na faixa”, valeu Gavin!), André Mesquita, entre muitos outros.

Vera Pallamin, minha orientadora, é também uma dessas pessoas. De dentro da Universidade e sendo sobretudo uma acadêmica, é dos poucos que, desse universo, efetivamente dialoga com todo o movimento cultural e artístico aqui analisado, de forma séria, competente e implicada. Ao longo desses quatro anos desde que comecei a escrever o projeto inicial para concorrer a uma vaga no Programa de Mestrado da FAU-USP, ela me ensinou diversas coisas, mas talvez a mais importante tenha sido essa: poder unir o rigor acadêmico com as minhas urgências para refletir sobre aquilo que fizemos ao longo desses doze anos, enquanto artistas-interventores no espaço urbano, ajudando-me a entrar em contato com as "dobras" do pensamento, necessárias para que ele adquira sinceridade e consistência.

Cibele Lucena, Peetssa (Fábio Invamoto) e Jerusa Messina, que começaram essa jornada comigo. Lembro das primeiras vezes 
em que nos encontramos, simplesmente para pensar juntos sobre o que estávamos sentindo, sempre partindo, em nossas conversas, das sensaçôes que tínhamos em relação à vida na cidade, da falta de conexão com o corpo, da falta de possibilidade de diálogo, do vazio de espaços de compartilhamento. Juntos, como corpo coletivo, pudemos sair do isolamento e começar a agir. Fizemos tantas coisas juntos, viajamos a tantos lugares, conhecemos tantas pessoas, tantas histórias e lutas. Esses são meus irmãos de "alma".

Agradeço ao TC (Antonio Carlos Santos da Silva), Suely Rolnik, Osvaldo e D. Mauri (Maurinete Lima), mestres. Desses mestres ancestrais, que ensinam muito além das palavras, mas com uma sabedoria fluida e generosa, que ocupa todos os espaços da vida. Verdadeiros professores.

Ao Rafael Leona, meu companheiro e grande parceiro de trabalho. Foi ele quem me introduziu em todo um universo de pensamento e ação argentino, em uma forma de sentir e fazer política, presente nesse país tão próximo ao nosso, mas que, às vezes, por nossa falta de conhecimento do que se passa ali, se torna tão distante. Com ele, pude conhecer muitos lugares e pessoas em Buenos Aires. Também é, atualmente, meu maior interlocutor, a pessoa com quem mais converso sobre as dúvidas e incertezas do pensamento e da vida. À minha querida mãe, Lia, única pessoa, além da minha orientadora, que leu e releu o meu trabalho todo, revisando, comentando, exigindo que a linguagem ficasse mais acessível para aqueles "de fora" desse universo reflexivo. Além disso, se não fosse o seu carinho e cuidado com o Sebastian, meu filho, certamente não teria conseguido chegar ao final deste trabalho. Quanto a isso, também agradeço a outras pessoas que foram fundamentais para que o Seba se sentisse acolhido, mesmo com as minhas ausências, necessárias, 
ao longo desse processo: Rafael, o pai; Breno, o avô; Diana e Chico, tios; a sua prima querida, Alice; aos bisavós Lygia e Nelson; à sua tiaprima Ruby (que também fez a primeira versão do abstract na faixa!), à tia-avó Cláudia e ao priminho Gabriel.

Ao Daniel Lima, parceiro de trabalho desde sempre e responsável pelo projeto gráfico desta dissertação. Foi das poucas pessoas com quem pude conversar sobre pontos que ainda não estavam muito claros e que me ajudou a entender imageticamente o trabalho.

À Regina Favre, que me ensinou a me desvincular de uma relação com o trabalho intelectual e acadêmico como "obrigação" e "busca de prestígio", para dar um mergulho necessário e verdadeiro na reflexão, tornando-a muito mais prazerosa e urgente. Sem isso, certamente o trabalho não teria sido concluído ou teria ficado bem menos colado às minhas verdadeiras necessidades de elaboração.

À Wilma Araújo Costa (in memorian), que sempre me incentivou a voltar para a Universidade, retomar os estudos, levar a sério esse caminho do pensamento. Obrigada Wilma, agora vejo o quanto valeu a pena. 
PROJETO JO 08:Layout 1 7/25/12 11:43 AM Pagse 10 
PROJETO JO 08:Layout 1 7/25/12 11:43 AM Paqge 11

para Seba e Rafa, meus amores

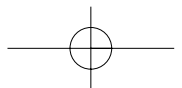




\section{Resumo}

\section{O E SPAÇO COMO OBRA: Ações, Coletivos Artís-} ticos e Cidade é uma reflexão a respeito dos processos de criação e impacto social das ações dos coletivos artísticos Contrafilé, Frente 3 de Fevereiro e Política do Impossível (de São Paulo) e GAC (de Buenos Aires), que começaram a atuar em meados dos anos I990. A dissertação foi desenvolvida a partir de diversas vozes, que se complementam e entrecruzam: uma voz narrativa, que vai apresentando descobertas feitas em minha atuação como artista no espaço urbano e que surge de uma dimensão local, inclusive íntima, chegando a uma voz mais "reflexiva e acadêmica"; vozes da grande mídia; as vozes dos próprios trabalhos artísticos apresentados; vozes dos coletivos, quando são utilizados como referências teóricas; e, por último, vozes de pensadores que de alguma forma influenciam o meu pensamento e o do movimento cultural do qual fazem parte as práticas urbanas aqui analisadas. O intuito é compreender como as intervenções urbanas, ao mesmo tempo, resultam e geram uma rede de afetos e significados e evidenciam a emergência de uma subjetividade política contemporânea que passa, necessariamente, por discutir e concretizar políticas de representação, relação, subjetivação e modos de vida alternativos aos impostos pelo neoliberalismo. Interessa, portanto, pensar como acontece e toma corpo a potência crítica situada deste tipo de resistência, configurando formas atuais do fazer político no contexto específico e complexo da cidade como escala e espaço referencial. O estudo se desenvolve como uma investigação ativa e participante de diversos trabalhos realizados pelos coletivos e através da qual me interessa observar essas ações/intervenções em seu poder dis- 
ruptivo, ou seja, em sua capacidade de presentificar acontecimentos que de alguma forma desestabilizem representaçôes sociais e sensações prévias. E que, ao evidenciar a possibilidade de fazê-lo, trazem à tona um saber circulatório que difunde a imagem produzida em situação (representação direta) e a experiência do "público" como obra.

palavras-chave: intervenção urbana, coletivos artísticos, subjetividade política, cidade, espaço, representação direta, práticas situadas, potência crítica, performance, imagem, arte contemporânea, artes (aspectos políticos, culturais, urbanos e sociais), artes século 2I, artes América Latina, arte pública, mídia e cultura, público, ativismo. 


\section{Abstract}

\section{The Space as the Work: Actions, Art Collectives and}

City is a reflection on creation processes and social impact of actions carried out by art collectives Contrafilé, Frente 3 de Fevereiro and Política do Impossível (from São Paulo), as well as GAC (Buenos Aires). These collectives have began work in the 1990's. The dissertation stems from multiple voices, which cross over and complement each other: a narrative voice that unravel discoveries made in my work as an artist in the urban space, emerging from a local and also intimate dimension, arriving at a "more reflexive and academic" voice; voices of the mainstream media; voices of the works studied; voices of the collectives, when they are mobilised as theoretical references and, lastly, voices of the thinkers who somehow influenced my thinking and voices of the cultural movement of which the urban practices under scrutiny are part of. The aim is to understand how the urban interventions at once result from and generate a network of affects and meanings, as they render evident the emergence of a contemporary political subjectivity. This subjectivity necessarily involves discussing and carrying out a politics of representation, relation, subjectivation and modes of life alternative to those imposed by neoliberalism. Under this light, the dissertation seeks to think how the critical potency situated in this kind of resistance can be embodied and takes place at all, configuring current forms of political making, in the specific and complex context of the city as scale and as referential space. This study developed as an active and participating investigation of several works carried out by the collectives. I seek to observe the actions/interventions in their disruptive power, i.e., in their capacity to render present events that somehow desta- 
bilise social representations and previous sensations. And which, as they evidence the possibility of being carried out, they bring to the surface a circulatory knowledge that diffuses the image produced in situation (direct representation) and the experience of the "public" as work.

keywords: urban intervention, art collectives, political subjectivity, city, space, direct representation, public, situated practices, critical potency, performance, image, contemporary art, art (political, cultural, urban and social aspects), 2I century art, Latin American art, public art, media and culture, public, activism. 
PROJETO JO 08:Layout $1 \quad 7 / 25 / 12 \quad 11: 43$ AM Passe 16 


\section{Índice}

Introdução

$2 \mathbf{I}$

Conversa introdutória

Capítulo I - nada é mais importante do que essa nuança fugidia

Aprendendo a se entregar ao risco

Não estamos em rebelião:

notando na hegemonia a diferença

Mídia Tática

Enunciação e emancipação

Metáforas do Confinamento

\section{Capítulo 2 - a cidade em disputa}

A cidade enquanto espaço referencial I54

Espacialização da norma e da invenção

Circulação: encontro do GAC com coletivos de São Paulo e contaminaçôes 


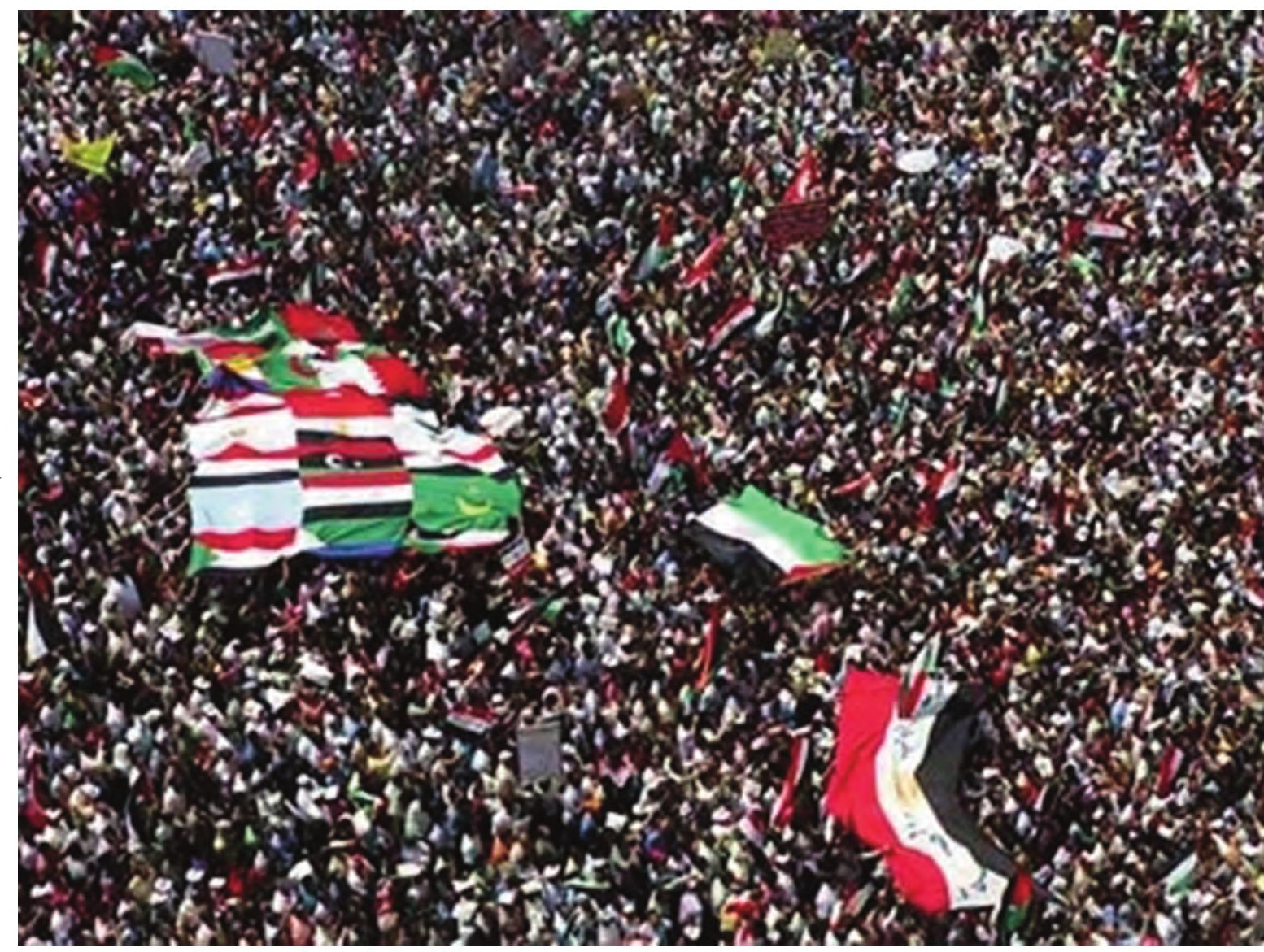

Primavera Árabe, Egito, 2011. 
A urgência não é uma bandeira, é uma necessidade que se impõe. ${ }^{I}$

1. Contrafilé, Lucas Bambozzi, Ricardo Rosas, Artigo Urgência in: Revista Parachute número 116 (São Paulo). Editora: Suely Rolnik, Montreal, Canadá, 2003. 
PROJETO JO 08:Layout 1 7/25/12 11:43 AM Pagse 20 


\section{INTRODUÇÃO}

Se existe algo a esboçar no atual ciclo de protestos (que, apenas para descrevê-lo rapidamente, tem períodos de máxima visibilidade com o contexto compreendido entre Seattle e Gênova ou a manifestação mundial contra a guerra do Iraque, momentos fundantes como a insur reição zapatista de 1994, efeitos em escala macropolítica como os processos de mudança institucional na América Latina, etc.), é seguramente a maneira como a inovação constitui uma característica estrutural das novas formas de ação e construção política que estão na base deste ciclo. Parece dar-se nesses anos uma verificação da imagem da máquina que Guattari e Deleuze utilizaram para denominar a necessidade de formas organizativas abertas e flexíveis para a criatividade política, para as quais as $\mathrm{di}^{-}$ mensões molar e molecular, micro e macro da política, puderam deixar de ser, como em outros momentos foram, mutuamente excludentes (Marcelo Expósito) ${ }^{2}$.

[...] O Manifesto do Movimento de 15 -M afirma muito claramente: As prioridades de qualquer sociedade avançada devem ser a igualdade, o progresso, a solidariedade, o livre acesso à cultura, a sustentabilidade ecológica e o desenvolvimento, o bem-estar social e a felicidade das pessoas'. [...] A cidadania hoje se constitui como tendência à auto-representação. Migrantes, mulheres, pessoas afetadas pelas hipotecas, pela destruição do meio ambiente ou pela degradação dos serviços públicos, comunidades agrupadas em torno de modos de vida sin- 


\begin{abstract}
gulares, redes sociais e um longo etcetera de composiçôes emergentes têm encontrado formas de falar por si mesmos, sem as formas calcificadas de mediação por parte do aparato institucional ou representativo. Tudo indica que a esquerda partidária será obrigada a atravessar, não apenas na Espanha, mas em toda a Europa, uma longa jornada através do deserto. É hora de assumir a obrigação de ensaiar, para um futuro próximo, novas abordagens que só podem passar pela aceitação dos limites de sua representatividade e pela cooperação com os movimentos e as formas de associação que crescem nas novas texturas urbanas [...] (Marcelo Expósito, Tomas Herreros e Emmanuel Rodriguez) ${ }^{3}$.
\end{abstract}

Nos últimos doze anos, ao longo dos quais estive permanentemente envolvida com práticas artísticas que encontram no espaço urbano um dos seus grandes referenciais, uma necessidade que sempre volta a se colocar para mim é a de pensar o lugar da cidade nessas práticas e, inversamente, o lugar dessas práticas na cidade; ao mesmo tempo, de compreender em que sentidos essa relação diz respeito ao mundo contemporâneo. Portanto, de fazer esse exercício de espelhamento em que a compreensão das problemáticas que se colocam hoje permite um entendimento mais profundo daquilo que gera esse tipo de experiência de produção e usufruto do espaço, no qual coletivos e artistas trabalham a partir da cidade, se vendo efetivamente como produtores dela.

Essa produção da cidade pelas práticas artísticas aqui analisadas é discutida como sendo um fenômeno não apenas macropolítico, mas também micropolítico, na medida em que acontece como 
um trabalho de elaboração da experiência de embate pela construção do espaço público. O estudo dos processos de criação e impacto social das açóes de coletivos artísticos que atuam desde meados dos anos 1990, auge das políticas neoliberais globalizadas, quando surgiram em distintas partes do mundo, evidencia que estes têm como uma de suas práticas mais contundentes a imersão em problemáticas situacionais e é daí que partem para apoderar-se da construção de discursos alternativos, criando com isso uma multiplicidade de for mas, representaçôes, soluçōes criativas e performáticas.

Focarei a prática de quatro coletivos: Contrafilé4, com o qual trabalho desde que iniciei, em 200I, as minhas pesquisas e práticas nesse campo de atuação (passarei pelo MICO, grupo a partir do qual o Contrafilé nasceu, para mostrar o surgimento de problemáticas que depois seriam aprofundadas de diferentes formas pelos outros grupos); Política do Impossível' , coletivo formado em 2005 que tem como foco a prática educativa como prática artística e do qual também faço parte; Frente 3 de Fevereiro ${ }^{6}$, coletivo de São Paulo que trabalha com a atualização das formas de compreensão do racismo na sociedade brasileira; e Grupo de Arte Callejero (GAC)7, de Buenos Aires, Argentina, que me permite abordar o problema a partir de uma perspectiva, ao mesmo tempo, local e (mesmo que minimamente) deslocada.

O critério usado para a escolha tem em vista a dimensão crítica do trabalho desses coletivos (ou seja, sua capacidade de pro-

\footnotetext{
4. "Formado em São Paulo, Brasil, no ano 2000, o Contrafilé é um grupo de investigação e produção de arte que trabalha a partir de sua experiência cotidiana, implicado na realização da vida pública, o que é, ao mesmo tempo, ponto de partida e território de proliferação do seu trabalho". In: A Rebelião das Crianças, publicação apoiada pelo VAI (Valorização de Iniciativas Culturais), São Paulo, 2007. O Contrafilé surgiu como decorrência do fim do grupo MICO, formado por cerca de 20 jovens no ano 2000 na cidade de São Paulo.

5. "O coletivo Política do Impossível - PI realiza projetos de educação e produção coletiva de arte desde 2004. Cria projetos de investigação e ação no espaço urbano que colocam os participantes como ativos na dinâmica da cidade, contra sua perpetuação como espaço dissociado da vida, tornando visíveis possibilidades e desejos de transformação no sentido da criação de vida pública. $O$ coletivo entende que é no exercício cotidiano de um olhar íntegro, capaz de relacionar informações e intervir na realidade, que se constitui a possibilidade de produzir sentidos, e não apenas reproduzi-los". In: Cidade Luz - Uma investigação-ação no centro de São Paulo, publicação realizada com o apoio do Minc/Funarte, São Paulo, 2008.
} 
duzir novos sentidos no e para o espaço urbano), em contraposição a outras práticas que são capturadas apenas como "produtos culturais". Além disso, conheço a história dos quatro grupos em profundidade e tenho acesso a um número extensivo de documentação sobre todos os trabalhos por eles realizados e às discussões sobre seus processos internos de produção e de decisões. O que é fundamental, já que esse tipo de reflexão, que tem como foco a teia micropolítica que se forma para que uma ação artística seja inscrita no espaço visível, macropolítico, conta, necessariamente, com esse tipo de material, nem sempre disponível ou objetualizado.

A relação de certo afastamento, que não chega a se configurar como uma negação, dos coletivos em relação às questôes do circuito mercantil da arte contemporânea, e o desconforto que possuem quanto às estratégias (institucionais) de sedução mercantil são outro ponto chave, pois permite uma leitura sobre o tipo de crítica institucional que desenvolvem, o que torna mais clara também a compreensão que têm em relação à produção dos espaços urbanos.

O que impulsiona a atuação dessa rede de colaboração na qual estão envolvidos os coletivos mencionados, é a possibilidade de disputar territórios materiais e simbólicos com os poderes hegemônicos. A prática artística se dá como uma tentativa de fazer emergir, como ao menos a "imagem da experiência de um devir", outros pro-

6. “A Frente 3 de Fevereiro é um grupo de pesquisa e intervenção artística acerca do racismo na sociedade brasileira. Sua abordagem cria novas leituras e coloca em contexto dados que chegam à população de maneira fragmentada através dos meios de comunicação. As intervenções artísticas criam novas formas de manifestação sobre as questões raciais. Para pensar e agir em uma realidade em constante mudança, permeada por transformações culturais de diversas escalas e sentidos, se fazem necessárias novas estratégias. A Frente 3 de Fevereiro associa o legado artístico de gerações que pensaram maneiras de interagir com o espaço urbano à histórica luta e resistência da cultura afro-brasileira". In: Zumbi Somos Nós - Cartografia do Racismo para o Jovem Urbano, publicação apoiada pelo VAI, São Paulo, 2006.

7. “EI GAC / GRUPO DE ARTE CALLEJERO se formó en 1997, a partir de la necesidad de crear un espacio donde lo artístico y lo político formen parte de un mismo mecanismo de producción. Es por eso que a la hora de definir nuestro trabajo se desdibujan los límites establecidos entre los conceptos de militancia y arte, y adquieren un valor mayor los mecanismos de confrontación real que están dados dentro de un contexto determinado". In: http://grupodeartecallejero.blogspot.com.br, acessado em junho de 2012. 
jetos de sociedade, sendo a cidade o domínio no qual as múltiplas escalas em jogo na disputa por esse projeto se evidenciam, se encontram, se sobrepóem, se atualizam e se confrontam. Essas imagens, que surgem a partir de determinadas situaçôes e problemáticas locais têm, por sua vez, um potencial de iluminar questôes em outros contextos situados, na medida em que tanto nomeiam - criando formas de tornar visíveis e legíveis - acontecimentos estratégicos na produção do espaço social contemporâneo, quanto ampliam a visibilidade e legibilidade deles, transformando-os em imagens que circulam e, assim, inserindo-os efetivamente em um "território circulatório" mais amplo.

Nesse processo, podemos dizer que se cria um tipo específico de "território circulatório estético e simbólico", no qual as imagens surgem da colaboração e mostram um uso alternativo, crítico e subversivo do espaço urbano, uma alternativa de produção do espaço social. Neste sentido, os símbolos, discursos, intervençôes criados pelas práticas artísticas situadas, podem ser entendidos como formas de forçar a entrada de dizeres dissonantes como produtores no/do espaço urbano.

Nos coletivos analisados, as formas de comunicação que articulam a própria cidade como mídia partem do princípio de que somente uma investigação situada é capaz de criar dispositivos estético-políticos com potencialidade de reinvenção do espaço social. Em relação à criação de uma perspectiva que dê conta da dimensão de acontecimento contida nesses trabalhos:

\section{[...] a teoria crítica estética, atualmente, abre outrasperspectivas de entendimento e atuação por meio da investigação das práticas e manifestaçôes como esferas de representação, nas quais os sujeitos sociais envolvidos e os sentidos são produzidos em situação (Pallamin, 2002, p. I07)}


Por isso, não pretendo realizar a análise do "movimento" ou uma cartografia para identificar grupos e circunscrever "tipos de ação". Mas sim, dar corpo conceitual para questôes que permeiam as discussóes e práticas aqui analisadas, tais como: como acontece e se expressa este tipo de resistência, no contexto específico e complexo da cidade como referencial; em que sentidos estas experiências, em sua potência ${ }^{8}$, podem ser entendidas como políticas; por quê estas formas do fazer político são vividas, entendidas e elaboradas em conexão indissociável com a dimensão do corpo; o que permitiu, antes de virtual ou presencialmente se conhecerem, que essas práticas ur banas surgissem e atuassem de forma semelhante em diversas partes do mundo; como se atualiza a noção de "comunidade" a partir da multiplicidade presente nessas práticas; que políticas de subjetivação estão sendo inventadas nesse movimento; como esse movimento cultural atualiza as formas de pensar e experimentar a crítica institucional; o que terá levado ao rompimento com disciplinas específicas ${ }^{9}$ e caminhos institucionalizados?

O enfrentamento deste campo problemático impõe a convocação de um olhar transdisciplinar, já que estão aí imbricadas inúmeras camadas da realidade, no plano tanto macropolítico (fatos e modos de vida em sua exterioridade formal, sociológica), quanto micropolítico (forças que agitam a realidade, dissolvendo suas formas e engendrando outras, num processo que envolve o desejo e a subjetividade) (Rolnik, 2006).

Vamos aqui compreender a "cidade" como esse "campo problemático". Portanto, em nenhum momento o espaço urbano será aqui colocado de forma "temática" mas, sobretudo, como espaço vivo

8. “[...] A saber: as ações e as paixões de que algo é capaz. Não o que a coisa é, senão o que é capaz de suportar e fazer. E se não há essência geral é porque neste nível, ao nível da potência, tudo é singular." Deleuze, Gilles. En Medio de Spinoza. Buenos Aires, Editora Cactus, 2004, p. 50.

9. Os coletivos artísticos, em sua maioria, são compostos por profissionais de diversas áreas: artistas plásticos, sociólogos, geógrafos, arquitetos, músicos, urbanistas, psicanalistas, etc. 
que se transforma na matéria prima de criação de todo um movimento cultural que pretende criar modos de vida alternativos, colocando em xeque diversos tipos de estruturas de poder.

O contato com universos de pensamento como o da sociologia e antropologia contemporâneas, foi fundamental já que trazem reflexôes sobre o que leva a cidade a ser a escala privilegiada para a compreensão das formas de produção social. Muitas questôes rever beram as estratégias através das quais as práticas artísticas situadas no espaço urbano discutem e disputam o projeto de cidade em curso, pois estas desafiam a pensar os limites entre o legal e o ilegal, o lícito e o ilícito, na medida em que se propóem a disputar a própria definição do que é legal e ilegal na produção do espaço. A partir do momento em que pensamos a cidade como um "campo problemático" no qual operam múltiplas situações de disputa, cabe lançar um olhar reflexivo para entender como ela aparece efetivamente nos trabalhos que serão aqui apresentados e por que é muitas vezes compreendida como espaço por excelência de experiência, reflexão, ação e de percepção de si e do outro; espaço no qual a invenção de uma outra forma de estar no mundo, de conviver e de construir os próprios valores e critérios de beleza e riqueza se torna viável. Será que podemos encontrar uma pista na ideia de Don Mitchell segundo a qual "Ao reclamar o espaço público em público, ao criar espaços públicos, os próprios grupos sociais tornam-se públicos" (Mitchell, 2003 apud Harvey, 2008, p. I6 ${ }^{\mathrm{r}}{ }^{\mathrm{O}}$ ? E, assim, aprender a produzir modos de deixar-se afetar pelo entorno e pelo outro somente seria possível em situação?

Uma questão que então se coloca é a de quais seriam as condiçóes para que a "representação direta" consiga condensar uma experiência crítica do conflito de forma esteticamente potente. 
A ideia de "representação direta" foi lançada pelo crítico de arte Brian Holmes em 200o, em Barcelona, durante o workshop "De la acción directa como una de las bellas artes":

Marcelo Expósito: Si te parece bien, comencemos por el término "representación directa". Consistía en una especie de mediación en el debate sobre las nuevas prácticas artísticas activistas que a finales de la década de los noventa, en algunos ambientes, se encontraba inútilmente polarizado entre dos extremos: 'representación' vs. 'acción directa'. [...] Martha Rosler habla de " $r e^{-}$ presentación participativa" para defender la necesidad de seguir produciendo representaciones no alienantes ni explotadoras en las que el sujeto representado tome parte activa, sin ser cosificado; $y$ tú propones este concepto, 'representación directa', en términos no muy alejados de los de Rosler.

Brian Holmes: Lancé esta idea de "representación directa" en el 2000, aquí mismo, en Barcelona, durante el taller "De la acción directa como una de las bellas artes". Era una provocación contra la vieja idea anarcosituacionista de que toda acción simbólica se encuentra alienada respecto al espectáculo unificado de la representación política y el imaginario comercial, de tal manera que la única respuesta solo podría consistir en un acto secreto, denso, invisible y rigurosamente material: bloquear algo, un tren, una autopista, una cumbre. Por supuesto que este tipo de acción puede ser extremadamente efectiva, pero desde el punto de vista artístico se puede hablar también de otras cosas. En el contexto del movimiento antiglobalización, que ha operado tan decididamente a través de Internet, e incluso a través de los medios de masas, la idea de una acción directa 'pura' está tan alejada de la 
realidad que parece absurda. Yo, por aquel entonces, trabajaba con Ne Pas Plier en proyectos que intervenían en la calle. Se trataba de distribuir 'medios de representación', de coger pegatinas u otros materiales impresos, y repartirlos en medio de la gente para que millares de personas pudieran llevarlos en su propio cuerpo y darles voz: usarlos, regalarlos a otras personas con el fin de cualificar una manifestación para que no fuera una mera masa de cuerpos, sino una colectividad que pretende decir algo. La gente podia hablar mediante esas imágenes, a la vez que la prensa y los fotógrafos que formaban parte del movimiento realizaban nuevas imágenes a partir de estos usos. De esa manera el evento transmitía un mensaje de multiplicidad: interpretaciones personales de ideas colectivas que se filtran a través de las diversas capas de la comunicación mediática, posibilitando diferentes tipos de efectos. [...] (Brian Holmes entrevistado por Marcelo Expósito, 2006, p. 345).

O estudo dos processos e trabalhos em pauta passa, portanto, por entender como, quando e por que as intervençóes artísticas têm um poder disruptivo, ou seja, são capazes de desestabilizar representaçôes sociais e sensações prévias; ao evidenciar a possibilidade de fazê-lo, trazem à tona a produção compartilhada de um novo imaginário a respeito do espaço e, com isso, a experiência do "público" como obra.

A intervenção na vida pública, para nós, é uma prática que permite - seja no âmbito da denúncia ou do anúncio - trazer à superfície e colocar em discussão o que estava presente em um determinado 
contexto, mas por algum motivo não estava sendo dito ou visto. Possibilita gerar um estranbamento de situações normalizadas dando lugar, nesse movimento, a uma mudança da chave de leitura sobre essas situaçöes. As formas a partir das quais estas intervenções são criadas, são singulares a cada contexto, já que este é necessariamente o ponto de partida e de chegada. A intervenção nos permite encarar de forma criativa os problemas sociais, politicos, culturais que nos atravessam todos os dias. Acreditamos que apenas a elaboração coletiva dos conflitos com todas as suas contradições e mistérios, possa ampliar as possibilidades de sua compreensão ao criar um espaço de fala, escuta, ação e reflexão. Para nós, esta tem sido uma forma de construir um posicionamento mais efetivo e consciente e de resistir à apropriação automática dos fatos - que os torna formas fixas e esvaziadas de experiência, estratégia clara de controle que contribui para a estabilização e reprodução de toda a estrutura bistórica de desigualdade e segregação social. Reinventar, a todo o momento, as formas de denúncia e anúncio dos fatos é, então, parte fundamental deste percurso (Contrafilé, 2007, p. 7).

O fato de que estejam contidas nestes modos de ação no espaço público tanto a dimensão coletiva quanto a dimensão estética não é, portanto, um apêndice deste processo. A dimensão coletiva, por um lado, é intrínseca ao próprio esforço por reivindicar o direi- 
to à cidade. Neste aspecto, para David Harvey:

\section{O direito à cidade não pode ser concebido simplesmente como um} direito individual. Ele demanda um esforço coletivo e a formaçāo de direitos políticos coletivos ao redor de solidariedades sociais (2008, p. 15).

Nos coletivos artísticos, este esforço está contido no ato de auto-organizar-se, estabelecer regras e condições de convivência e produção e, por fim, no gesto estético que intervêm no âmbito do público. A dimensão estética, por sua vez, tem profunda relação com a força de um corpo que se coloca em risco ${ }^{\text {II }}$ para tornar visível e legível o instante de invenção de um espaço social com determinadas qualidades.

Um componente a ser observado nas ações dos grupos em pauta e que é determinante na maior ou menor potência do gesto estético, é a escolha do contexto onde a intervenção é feita em relação às qualidades do espaço denunciado e anunciado. Interessa pensar como se dá o complexo cruzamento entre uma intervenção artística e o espaço social para que a construção simbólica tenha a potência de "interferir na narrativa social, de gerar, por mais mínimos que sejam, deslocamentos na configuração estabelecida do possivel" (Política do Impossível, 2006).

É importante também destacar alguns aspectos que marcam o trabalho. Apresenta-se a construção de uma narrativa que partiu daquilo que movia as preocupaçóes de um determinado grupo, como base para uma interpretação de caráter mais conceitual. Assim, ao mesmo tempo em que existe um fio cronológico no trabalho, este é

11. Essa ideia de um "corpo que se coloca em risco" é bastante utilizada nessa dissertação e diz respeito à forma acionada pelo tipo de trabalho que será aqui analisado, na qual o "sujeito" se coloca no centro de situações sociais conflitivas para denunciar e anunciar aquilo que está vendo, pensando e sentindo. Esse tipo de fazer político-artístico resulta em soluções imagéticas nas quais captar o corpo em confronto com o espaço, ou o indício desse enfrentamento, se torna fundamental. 
a todo momento interrompido por inflexôes que representam descobertas do pensamento conforme a memória é ativada. Saltos e sobressaltos são dados, criando uma teia de ideias que opera a partir de diversas temporalidades sobrepostas.

Ao longo da pesquisa há uma tentativa de privilegiar a idéia de "investigação-ação", na qual a própria investigação é compreendida como intervenção. Trata-se do exercício de dar corpo conceitual a experiências que são de fato relevantes para aquele que as pensa, acarretando novas experiências. Como diz o coletivo argentino Situaciones:

Se nos referimos ao compromisso e ao caráter 'militante' da investigação, of fazemos em um sentido preciso, ligado a quatro condições: a) o caráter da motivação que sustenta a investigação; b) o caráter prático da investigação (elaboração de hipóteses práticas situadas); c) o valor do investigado: o resultado da investigação só se dimensiona em sua totalidade em situações que compartilham tanto a problemática investigada quanto a constelação de condições e preocupações; e d) o seu procedimento efetivo: seu desenvolvimento éjá resultado, e o seu resultado redunda em uma imediata intensifícação dos procedimentos efetivos. (Colectivo Situaciones e MTD Solano, 2002, p. 13-14)

O plano teórico de forma alguma pretende se descolar da experiência para tornar-se uma espécie de voz racional da verdade. Esse exercício de fortalecimento da reflexão a partir da prática tem, no 
entanto, uma série de conseqüências. Uma delas consiste na opção em apresentar, em alguns momentos, vozes, imagens e reflexôes que no andamento processual de certos trabalhos evidenciam certa ingenuidade. A menção a estes momentos tem por objetivo mostrar como se deu, em diversas ocasiōes, essa passagem do desejo, da fragilidade, da incerteza, do confronto, para a produção de trabalhos e reflexôes com forte impacto simbólico - já que é justamente nesse movimento que encontramos a potência dos gestos artísticos aqui apresentados.

Por último, uma das tantas dificuldades que se apresentaram ao longo deste trabalho de elaboração foi diferenciar as diversas vozes que o compõem. A minha voz como "estudante e pesquisadora"; a minha voz enquanto artista e as vozes dos outros artistas (coletivos) aqui apresentados enquanto citaçóes; as vozes teóricas e da mídia que, em diferentes sentidos, são referências para a construção do pensamento aqui desenvolvido; as vozes dos coletivos, tanto dos quais eu faço parte, quanto dos que eu não faço, quando essas são interpretadas por mim enquanto textos-obras ${ }^{12}$. $\mathrm{O}$ critério utilizado para entender que o texto dessa dissertação deveria evidenciar o aspecto múltiplo dele mesmo, foi a característica comum tanto dos coletivos aqui acionados, como de tantos outros que compõem essa rede de colaboração, de refletir sobre a própria prática, produzindo textos, livros, manifestos que são, de fato, compreendidos como obras, assim como o são, obviamente, as imagens, performances, intervençôes.

12. Nesse sentido, a produção de imagens adquire um caráter amplo, pois diz respeito à invenção e/ou subversão de imaginários, o que pode ser feito através de estratégias distintas (texto, fotografia, intervenção urbana, leituras críticas de jornais, etc.) e muitas vezes sobrepostas. 


\section{Vozes:}

I.

a minha voz como "estudante e pesquisadora".

2. a minba voz enquanto artista e as vozes dos outros artistas (coletivos) aqui apresentados enquanto citações.

3. as vozes teóricas e da mídia que, em diferentes sentidos, são referências para a construçäo do pensamento aqui desenvolvido.

4 . as vozes dos coletivos enquanto textos-obras.

5 .

os textos-obras dos coletivos enquanto documentos. 


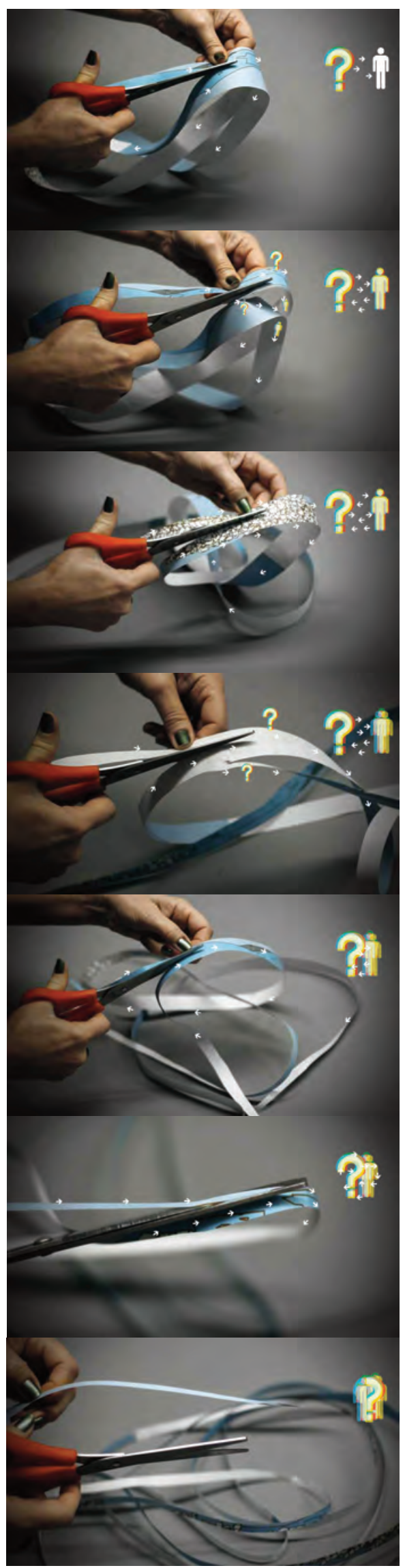

Sequência de imagens concebidas por Suely Rolnik e realizadas pelo coletivo Bijari, assim denominada pela autora: "Caminhando pela fita de Moebius com Lygia, os Tupinambá e alguns franceses para rastrear 0 processo de produção da subjetividade e da cultura".

Parte de sua apresentação

"Para além do inconsciente colonial", 2012. 


\section{Conversa Introdutória}

Abaixo, reproduzo alguns trechos da "conversa" ocorrida no meu exame de qualificação de mestrado ${ }^{13}$ que lançam questôes para mim fundamentais e que serão tratadas ao longo do trabalho. Não opto por colocá-la aqui de forma arbitrária, mas porque, ouvindo a gravação, percebi que contribuiu para que eu pudesse, mais uma vez, retomar alguns aspectos daquilo que venho construindo enquanto prática e pensamento nos últimos doze anos.

Suely Rolnik, não sem razão amplamente citada neste trabalho reflexivo, foi também parte da banca e as ideias trocadas com ela naquele dia específico ganham uma forma legível para presentificar o tipo de interlocução que tem sido construído entre muitos artistas e coletivos e essa pensadora. A partir de seu olhar interessado e de seu corpo aberto, sempre trouxe de forma vibrante para nós, como importante base de sustentação de nossas indagações, dúvidas, reflexões e, claro, ações, uma forma de pensar abrangente, crítica e sensível às forças do mundo.

Além de tudo isso, a conversa, como forma de elaboração de espaço social, é de onde nascem os trabalhos que serão aqui apresentados. É no embate pela produção de um pensamento vivo e compartilhado, que os coletivos artísticos partem para inscrever novas configurações de mundo.

Joana Zatz Mussi: Quando iniciei o mestrado, me interessava aprofundar teoricamente as práticas dos coletivos artísticos dos quais faço parte ou sou colaboradora, mas o projeto de pesquisa ainda estava muito vago. Cursando as disciplinas, lendo novos autores, me distanciando minimamente do turbilhão do fazer, pude ter uma relação

13. Estavam presentes Joana Zatz Mussi, mestranda, Vera Pallamin (Área de Projeto, Espaço e Cultura da FAU-USP), orientadora desta dissertação, e, como membros da banca examinadora, Suely Rolnik (Núcleo de Estudos da Subjetividade - Programa de Pós-Graduação em Psicologia Clínica da PUC-SP) e Sérgio Regis Moreira Martins (Departamento de Projeto da FAU-USP). São Paulo, 16 de janeiro de 2012. 
mais reflexiva com os trabalhos, o que me permitiu entender qual é a questão fundamental para mim, que é a da atuação na cidade e como essas práticas urbanas evidenciam, na produção imagética e simbólica que realizam, as formas e mecanismos de produção e reprodução do espaço social na contemporaneidade.

Em alguns momentos, a atuação ocorre em processos sociais já em curso, dando visibilidade e legibilidade para eles, em outros, há a invenção de processos; nos dois casos, é o corpo em risco, o embate entre o corpo e o espaço urbano evidenciando as formas e mecanismos contemporâneos de produção, o que gera um entendimento da dimensão estética nesses trabalhos. Nesse sentido, é importante realizar uma interpretação do que é "a cidade" nessas e para essas práticas, como lugar de partida e de chegada, como lugar físico e simbólico, como presença e também como devir.

A interpretação de como "a cidade" aparece e é acionada em alguns trabalhos artísticos a partir dos quais proponho uma reflexão, de como um corpo individual ou coletivo se constitui no embate com a escala urbana, além de ser um problema estético e político, também tem a ver com toda uma discussão feita pelas ciências sociais contemporâneas na tentativa de entender a cidade como espaço referencial em um momento histórico no qual não há mais nada que possa ser pensado estando fora do marco do urbano.

A partir disso, muitas questôes emergem e uma delas é o tipo de crítica institucional feita pela geração de coletivos artísticos que começou a atuar em meados da década de r990 e aprofundou a sua prática nos anos 2000. Alguns autores, como o crítico norte-americano Brian Holmes, o artista e pensador espanhol Marcelo Expósito 
e mesmo Suely Rolnik, aqui presente, dizem que essa geração tende a "entrar e sair da instituiçãa", entendida não apenas como uma instituição artística. Isso significa que as formas de relação institucional se transformaram, e que dependem também da compreensão que as práticas aqui abordadas têm sobre o que é o marco do urbano. E se concordamos que hoje não é mais possível pensar em um espaço que esteja fora desse marco, fica evidente que as instituições também estão operando a partir dele, portanto, em múltiplas escalas simultaneamente, e que é possível disputar a produção e a re-produção do espaço social mesmo de dentro de uma dimensão institucional mais formalizada.

E o que é o "espaço social"? Porque se me interessa entender como, nessa produção imagética, se cria legibilidade e visibilidade para as formas pelas quais o espaço social é produzido e reproduzido, é preciso ao menos iniciar uma tentativa de definição de como estou entendendo o que é esse espaço. Aqui, começo essa tentativa, por exemplo, quando a partir das práticas percebo uma dimensão física e uma dimensão simbólica operando simultaneamente em justaposição; quando percebo que ele pode ser entendido prioritariamente a partir do marco do urbano e que isso não significa rua ou prédio, mas uma forma que atravessa tudo e que pode ser definida a partir da disputa pela definição do que é legal e ilegal, lícito e ilícito, formal e informal, na produção do espaço. Outros pontos importantes a serem olhados criticamente na definição do que seria o espaço social compreendido a partir dessas práticas são os atravessamentos, as redes, as conexóes, que geram uma grande mobilidade daquilo que é produzido e o encontro de um espaço comum e compartilhado.

As práticas artísticas aqui analisadas aparecem nesse contexto, portanto, como parte fundamental da disputa pela produção 
do espaço na contemporaneidade e tendo como papel principal a criação das imagens de como isso está se dando; porque o know how e a expertise que foi sendo criada é essa, de um saber circulatório que nasce a partir da potência dessa representação. E como definir a potência, como entendê-la?

O saber circulatório pode ser entendido como um indício da potência de uma imagem. No momento em que essa imagem está sendo elaborada, a sua potência e a possibilidade de que circule não são conscientes, mas é possível sentir a sua consistência pelo quanto carrega de uma experiência real. É isso o que vai fazer com que se prolifere a produção crítica de imagens que tornam visível e legível como a produção do espaço social está se dando em diversos contextos. Sabemos que essas imagens ensinam alguma coisa justamente quando guardam a experiência de um possível como memória das potências sociais dessas imagens.

Suely Rolnik: Você é uma testemunha viva desse movimento cultural $^{\mathrm{I} 4}$, por isso a importância de registrar, conceituar o que se passou, fazer proliferar. Existe aí uma inquietação. Quando você diz que a cidade se produz em mil camadas e dimensóes e que as instituiçóes também, o Felix Guattari tem um conceito interessante para falar disso, que é o conceito de "transversalidade". Através desse conceito, ele fala como a gente é composto do que é imediatamente visível e de muitas outras camadas invisíveis e que é essa dinâmica que vai nos formatando, nos constituindo.

Considero essa uma questão central do seu trabalho e vou falar agora um pouco sobre ela. Quando você diz que os grupos trabalham em situações de tensão que já estão lá, nomeadas de alguma

14. A ideia de que os coletivos artísticos aqui apresentados fazem parte de um movimento cultural mais amplo, aparece em diversos momentos desta dissertação e se refere ao fato de que eles estão inseridos em um conjunto de práticas políticas e estéticas que surgiram a partir dos anos 1990 tendo como mote a luta contra o capitalismo contemporâneo, a precarização da vida de modo geral, a reapropriação do espaço público pelas pessoas, a invenção de novas formas de sociabilidade e contestação frente à chamada "sociedade de controle". Ao longo do texto, algumas das características que marcam este como um "movimento cultural e artístico", serão analisadas e ficarão mais clara. 
forma, e em outras que vocês "inventam" - eu diria que vocês nomeiam a partir de uma dimensão micropolítica -, é isso o que para mim significa colocar o corpo em risco. Por que, afinal, que corpo é esse que se entrega ao risco?

Você está falando sobre a introdução desse conhecimento do corpo na avaliação do estado das coisas e na condução das ações; a introdução e o desenvolvimento do conhecimento de como dar corpo sensível para essas sensações; o que é um ato de resistência fundamental ao pensamento inventado pela Europa Ocidental e que recalca o corpo e restringe o pensamento à percepção e à razão.

Não inventamos porque somos inspirados por Deus, mas porque nesse conhecimento corporal, das forças ambientes, os afetos do corpo já estão indicando essa necessidade... Uma coisa é denunciar, outra é anunciar... Já está se anunciando nesse conhecimento corporal uma dinâmica tensional que convoca você a dar corpo para isso, no caso das práticas das quais estamos falando, através de uma proposta de intervenção na cidade. Não é que algumas situações existem e outras ainda não existem, é que algumas ainda não estão no campo do visível, ainda não estão operando como tensão macropolítica, mas já estão presentes no corpo.

Quando você fala em "colocar o corpo em risco", eu entendo muito mais esse anunciar do que o denunciar. Se você levasse somente em conta o fato de ser filha de militante ${ }^{15}$, esse colocar-se em risco significaria se matar para denunciar; como você é de uma geração que está tentando ampliar o campo da política, até para honrar os seus ancestrais, sabe que hoje, o que faz sentido, é o corpo estar ali implicado para anunciar.

Nós, como fomos estruturados pela cultura inventada na $\mathrm{Eu}^{-}$ ropa Ocidental, pelo processo de colonização, capitalismo, subje-

15. Os meus pais fizeram parte do movimento político contra a última ditadura militar, sendo filiados aos grupos VAR - Palmares e Ala Vermelha do PCdoB. Foram perseguidos e, para não serem presos, se exilaram em países europeus. 
tividade burguesa, etc., funcionamos no registro da percepção, da consciência, da vontade, da representação, do sentimento, e do sensorial também. E o sensível também faz parte do regime da percepção, porque nele tem um sujeito percebendo um objeto. E o que está recalcado na nossa cultura e está, por outro lado, muito presente nas culturas que nos constituem no Brasil, as culturas africanas, indígenas e culturas mediterrâneas, árabes, judaicas e o cristianismo pré-igreja católica apostólica romana, é essa dimensão da subjetividade ativa. Porque o próprio da subjetividade burguesa, capitalista, é o recalque do corpo na cotidianidade, no modo de aprender, na produção cognitiva, na condução do pensamento e da existência. Nessas culturas, que também nos constituem, isso não está apenas presente, como é ritualizado na cotidianidade.

Posso olhar as situaçóes e as tensões próprias da cartografia do presente, como estão organizados os conflitos de raça, de classe, de gênero; mas têm situações nas quais existe uma tensão paradoxal entre o que o seu corpo está captando e a cartografia do presente, o que te coloca em crise. Então, a intervenção será a invenção de algo que vai dar corpo para isso que está se anunciando, mas ainda não está na dimensão do visível. A denúncia e o anúncio são fundamentais, o que não podemos é reduzir o que fazemos a uma coisa ou outra. Por exemplo, se ficamos só na dimensão do desejo e não fazemos o movimento de dar corpo ao que está acontecendo em uma ação, um conceito, no que for, construindo uma representação que se inscreva na realidade visível, não acontece nada e essa pulsão vira pura esterilidade também.

Deleuze e Guattari falam em perceptos, um modo de percepção que não passa pela linguagem e que é essa experiência do mundo como corpo vivo, como campo de forças. E a sensação, para 
Deleuze e Guattari, não tem a ver com o sensorial, é a sensação da tensão, do paradoxo, entre isso que o corpo vivo já está captando e o modo como as coisas estão formatadas. E é essa sensação que dispara a criação, então não é a experiência sensível que vai ganhando corpo, é a experiência do vivo que vai ganhando corpo sensível e se atualizando.

E por que as imagens produzidas nessas práticas urbanas ensinam? Não é só porque eu vou imitar, tem isso também... Mas, principalmente, porque essa ação é portadora de uma experiência de algo que está se anunciando e que eu compartilho. Se eu consigo fazer algo bom, com rigor e disciplina, e que carregue isso que se anuncia, essa ação imediatamente reverbera. A sua ação ensina porque é por tadora de uma experiência real. Uma coisa é então descrever o que se passou ali, outra coisa é mergulhar na memória dessa dimensão da experiência e tentar fazer uma ação conceitual, criar conceitos para tornar dizível o que está ali.

Mas acho importante tocarmos aqui nessa potência, tendo como indício o saber circulatório do qual você fala. É preciso deixar clara uma visão crítica da mobilidade, portanto, nem resistir a ela e nem celebrá-la. No Brasil, tendemos a idealizar a mobilidade, a antropofagia, com uma falta de visão crítica em relação a essas ideias, tão presentes hoje no sistema da arte em sua identificação com o neoliberalismo.

Por isso, vejo um problema fundamental aqui para desenvolver, que é discriminar melhor esses dois campos nos trabalhos analisados, principalmente o conceito de micropolítica, porque macropolítica todos nós dominamos. Isso implica de fato, como você disse, em circunscrever melhor o que entende por "espaço social", porque é fundamental tentar elaborar como o espaço se produz nesse 
movimento do micro ao macro e não apenas no espaço macropolítico.

No meu entender, o conhecimento estético é exatamente esse conhecimento da passagem do micro ao macro, de colocar o corpo em risco para performatizar o invisível, aquilo que já é vivido como real mas ainda não encontra representação na realidade. É o conhecimento desse corpo, vulnerável às forças do mundo, que desencadeia a necessidade de pensar como sinônimo de criar e que não vale somente para a arte. Mas como falar dessa experiência do corpo?

Uma coisa é falar dessa experiência como um encontro com o outro, como um sujeito que "interage" com outro sujeito, ainda na lógica de sujeito e objeto. Outra é falar a partir dessa lógica na qual já não há sujeito e objeto, mas um corpo mergulhado em um campo de forças que desencadeia nesse corpo a sua potência de criação, o que vai resultar em uma reconfiguração tanto do sujeito quanto do ambiente. Essa história de interagir com o outro é o mínimo que você espera de um ser humano, reconhecer a existência do outro e os seus direitos civis, mas temos que agregar a dimensão da vulnerabilidade de um corpo a esse campo de forças, que tem a ver com a transversalidade do Guattari, quando ele entende a subjetividade como a dinâmica de todos esses atravessamentos.

Nesse caso, já não dá para falar em um "outro”. Existe esse "outro" do direito civil, mas existe uma alteridade que nos habita, que é aquilo que escapa do outro como representação, e mesmo da representação de nós mesmos. Essa alteridade é esse campo de forças atravessado pelas forças do mundo e que está o tempo inteiro colocando em xeque as formas do presente. Essa alteridade, nesse sentido, não é o outro que está fora, é uma alteridade que me constitui, que não para de me fazer, desfazer, me desmanchar, e que não para 
de me obrigar a pensar no sentido de criar e agir. E eu penso nisso como um grande ponto de interrogação, porque coloca um problema a cada momento na medida em que coloca problemas que obrigam a pensar.

Quando você fala que a dimensão estética está na constituição de um "possível", é importante distinguir bem essa ideia, porque o "possível" está na dimensão do visível, da representação, mas dentro do campo da micropolítica, do invisível, não se fala em possível. Aí tem um virtual que já está se anunciando e que vai se atualizar em uma outra coisa, que não tem a ver com o possível, pois esse está contido no modo como está constituído o presente. Importa então que fique claro isso, não importa tanto o nome que você vai dar, mas que fique claro o lugar de cada coisa. Mas como você chamaria isso, se não é possível, de devirír? Eu chamo cada hora de um jeito, mas agora estou chamando de imanência. ${ }^{17}$

$\mathrm{Na}$ dimensão do visível, podemos falar em oposição, contradição, dialética, porque de fato entre preto e branco, homem e mulher, ricos e pobres, classe dominante e classe dominada, existem interesses que são opostos mesmo. Mas não podemos dizer que o que está se anunciando a partir do campo da imanência, do que ainda não é visível, é o contrário do que é visível; isso que se anuncia é uma outra coisa, é um deslocamento, não tem síntese, ele pode mudar a configuração do presente, mas não é a negação do presente e nem está contido nele como possibilidade.

Esse movimento, quando estou tomada pela urgência das forças que me atravessam e elas ficam me azucrinando enquanto eu

16. No livro Cartografias do Desejo, Félix Guattari e Suely Rolnik definem "devir" da seguinte forma: "Devir: termo relativo à economia do desejo. Os fluxos de desejo procedem por afetos e devires, independentemente do fato de que possam ou não ser rebatidos sobre pessoas, sobre imagens, sobre identificações. Assim um indivíduo, etiquetado antropologicamente como masculino, pode ser atravessado por devires múltiplos e, aparentemente, contraditórios: devirfeminino que coexiste com um devir-criança, um devir-animal, um devir-invisível, etc. [...]" (2005, p. 382). Em O Vocabulário de Deleuze, François Zourabichvili define da seguinte forma o significado de "devir" para Deleuze, com o qual Suely Rolnik também opera aqui: "Devir é o conteúdo próprio do desejo (máquinas desejantes ou agenciamentos): desejar é passar por devires" (2004, p. 24). 
não invento alguma coisa, esse movimento, que seria uma ação do pensamento, é a produção de um devir, uma sublime ação, algo que dê corpo para o que nos atravessa. É sublime porque é uma ação ética por excelência: se responsabiliza pela possibilidade de afirmação da vida e não de um sistema de valores. Então, quando a gente inventa alguma coisa nesse sentido, estamos produzindo um devir em nós mesmos e no ambiente.

Por isso, um grande deslocamento é o de uma concepção tanto de tempo quanto de espaço restrita à dimensão da representação, para uma outra concepção, que é do tempo como devir, porque aí ele é a própria constituição de espaço, ele não existe se não se atualizar como outra forma de espaço. Nesse sentido, não dá simplesmente para passar do tempo histórico para o espaço social como referencial para entender o contemporâneo, pois a temporalidade é indissociável do engendramento de espaço, não há como separar uma coisa da outra.

Joana Zatz Mussi: E você acha que é possível pensar esse engendramento do tempo-espaço social a partir da micropolítica?

Suely Rolnik: Tanto eu acredito que dedico a minha vida inteira a isso. Eu acredito plenamente, essa é a minha maior convicção. Hoje em dia eu acho que essa é a atitude de resistência política mais fundamental, do ponto de vista micropolítico, a toda a história colonial, do império da Europa Ocidental sobre o planeta, que inibiu e recalcou essa capacidade cognitiva que é nossa bússola vital, diferente de uma bússola moral, ligada à justiça social, por exemplo. Eu posso defender os valores de justiça, mas estar super reativa ao que a vida está pedindo, porque estou com a bússola vital danifi- 
cada, recalcada, sendo que é ela que nos dá a noção de onde a vida está totalmente estrangulada e onde tem que colocar energia para ela deslanchar.

A Lygia Clark, quando chamava os objetos que fazia de "objetos relacionais", o que estava tentando com a obra dela, na minha leitura, era ativar essa dimensão "micro" da subjetividade, tanto que no último trabalho, em que ela traz essa dimensão terapêutica, não é que ela virou terapeuta, é que ela incluiu uma dimensão clínica na proposta artística dela porque ela se deu conta de que você pode estrebuchar e virar do avesso para que o espectador viva uma experiência que vá convocar isso - essa dimensão da potência, da micropolítica, da imanência -, mas a barreira neurótica de recalque disso é tão poderosa em todos nós que não adianta... Então, ela faz um trabalho no qual justamente está explorando essa barreira.

Tudo isso nos faz pensar o que estamos aqui chamando de política. Estamos acostumados com o conflito entre o poético e o político. O que eu gosto dessas histórias, é poder entender que a experiência do mundo como corpo vivo que nos atravessa é política, é micropolítica. Você sair do recalque, dar conta do que o corpo vivo está anunciando e fazer a sublime-ação, é ético e é político...

Vera Pallamin: Merleau-Ponty critica a relação entre sujeito e objeto, rompendo com essa dicotomia que você comentou. Desde o começo isto está presente em sua filosofia, e depois, em textos como "O Olho e o Espírito" e outros, em direção à etapa final do seu trabalho, isso se evidencia reiteradamente. Isso implicou em sua revisão da noção de alteridade - ele diz: "Sou eu mesmo sendo sempre outro"... Pode-se estabelecer um diálogo entre a filosofia dele e várias coisas que você falou. No artigo em que falo da Frente 3 de Fevereiro 
como um corpo coletivo segurando aquela imensa bandeira ${ }^{18}, \mathrm{Mer}^{-}$ leau-Ponty me ajudou a pensar aquela ação enquanto vontade e corpo coletivos. Estou dizendo isso, porque fico pensando se seria possível entender o que você está dizendo a partir de um outro referencial teórico, que não necessariamente o da psicanálise...

Suely Rolnik: É sim possível entender tudo isso sem ser "psicanalista”. Alguém que tenha uma experiência psicanalítica pode entender muito bem, porque não depende apenas de uma experiência teórica, eu acho que alguém que freqüente um candomblé bom, que tenha a experiência do transe, que tenha alguma relação com a cultura africana, é tão capaz de entender quanto alguém que encontrou um bom analista. No fundo, tudo isso que fazemos e sobre o que falamos hoje aqui são intervenções políticas na cultura, formas de reativar essa dimensão da imanência na cultura, essa dimensão do corpo, das pulsões e do desejo. 
PROJETO JO 08:Layout $1 \quad 7 / 25 / 12 \quad 11: 43$ AM Pagse 48 
CAPÍTULO I

Nada é mais importante do que essa nuança fugidia 


\section{Aprendendo a se entregar ao risco}

Durante a montagem da exposição "Brasil + 500 - Mostra do Redescobrimento" em abril de 2000 (na qual a Fundação Bienal de São Paulo "celebrava" os 500 anos da chegada dos portugueses ao Brasil e o início do país como a nação que conhecemos), alguns jovens que se preparavam para trabalhar como monitores perceberam o que consideraram algumas "inconsistências" no evento. Em documento escrito na época, o grupo, depois batizado de "Grupo MICO”, diz:
I. É um megaevento que envolve milhões dos cofres públicos;
2. Os trabalhos quase somem diante de cenários, colocados para "facilitar" a sua assimilação pelo público;
3. A exposição será levada a muitos países para servir de "vitrine" do Brasil diante do mundo- enquanto milhares de instituiçб̄es de arte e artistas brasileiros estão falindo por falta de incentivo; 4. Não há a promoção de uma discussão pública sobre o significado dos "50o anos", mas sim uma visão espetacularizada do genocídio e da colonização. ${ }^{\prime \prime}$

Em reuniōes para discutir estes e outros aspectos da $\mathrm{ex}^{-}$ posição, chegou-se à conclusão de que era necessário demonstrar a insatisfação com a leitura histórica ali contida e com as distorções que as políticas públicas de incentivo à cultura e à arte sofrem no Brasil. 
Os jovens que estavam ligados à Fundação Bienal pediram demissão e junto a amigos com quem iniciaram essa discussão (for mando um grupo de estudantes universitários que estavam concluindo cursos diversos - geografia, ciências sociais, artes visuais, arquitetura, jornalismo), resolveram problematizá-la indo para a rua e intervindo no espaço público a partir de estratégias diversas (manifesto escrito, performance e intervenção urbana). O grupo via ali a oportunidade de tornar nítida a falta de aprofundamento e revisão crítica da memória social brasileira em uma exposição com tanta visibilidade.

Estavam reconhecendo o direito de interferir no pensamento cultural dominante que toma para si por completo o espaço simbólico de construção da identidade nacional. Nesse sentido, o grupo iniciou um movimento de gestação de formas para re-nomear e deslocar simbolicamente experiências e imagens produtoras de identidade, portanto, de subjetividade, ao questionar essa suposta "identidade nacional". Buscava produzir um espaço de auto-reconhecimento por não se reconhecer no que nomeou como uma "celebração estereotipada". A expectativa do MICO era de uma atualização da discussão que pudesse trazer à tona a experiência de confronto e crise presentes em nosso cotidiano, de abertura para uma reflexão social coletiva que permitisse a construção de significados alternativos e compartilhados.

Segundo Agnes Heller, a passagem da aceitação do estereótipo para um sadio mergulho na crise está ligada ao processo de singularização e de construção de um espaço de aspiração humana no qual se deseja conhecer melhor aquilo que nos constitui. 
$O$ aparecimento de estereótipos dificulta extraordinariamente a tarefa do conbecimento dos homens. Pois, quando o homem desempenha um papel, é perfeitamente possivel que não se "manifeste" de modo algum naquilo que faz e que suas relaçôes sociais não aumentem a variedade de sua substância. Na estrutura própria do papel, degradam-se as relaçôes sociais, que deixam progressivamente de ser elementos qualitativos para serem apenas quantitativos. Por muitos que sejam os papéis desempenhadospelo sujeito, sua essência se empobrecerá. [...] Também aqui estamos diante da alienação de uma propriedade característica do homem. [...] A recusa do papel é característica daqueles que não se sentem à vontade na alienação. Mas o conflito moral é inevitável [...]. Os'representantes da teoria do papel' são inimigos irreconciliáveis de todo conflito. Interpretam o conflito como 'defeitos de organizaçâa', 'perturbaçôes funcionais corrigiveis', alguns chegam a interpretá-los como 'complexos', perturbaçôes psíquicas. Mas o conflito é a rebeliāo das sadias aspiraçôes humanas contra o conformismo: é uma insurreição moral, consciente ou inconsciente (Heller, 2004, p. 87-IIо).

Uma exposição daquele porte, para a qual foram editados I4 catálogos e que percorreu o país em 43 diferentes exibições, que ocupou a OCA, o Pavilhão da Bienal que é hoje o Museu Afro Brasileiro evidenciava, para o grupo, a arte como espetacularização da vida, subjugada e colocada a serviço da expansão do sistema capitalista contemporâneo. O esvaziamento do sentido crítico em tal situação, fica claro na fala de Edemar Cid Ferreira, à época presidente da Fundação Bienal:

Decidimos incluir na mostra um elemento revolucionário que mu- 

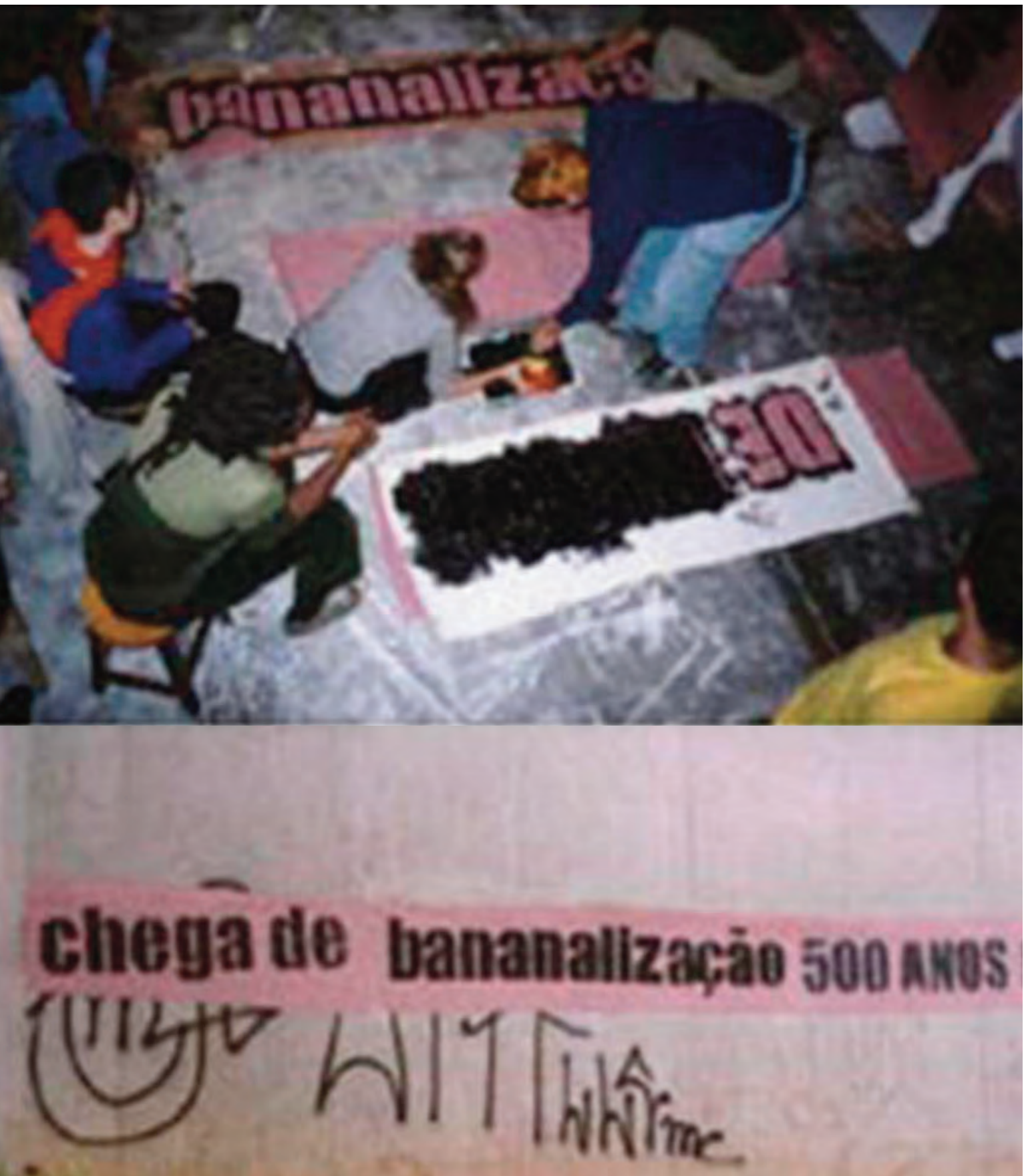

Frase "Chega de Bananalização, 500 anos de Mico" na rua, MICO, São Paulo, 2000. 


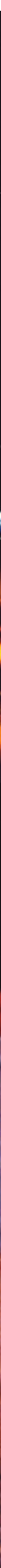

Cobertores cobrindo o Monumento às Bandeiras, MICO, São Paulo, 2000. 

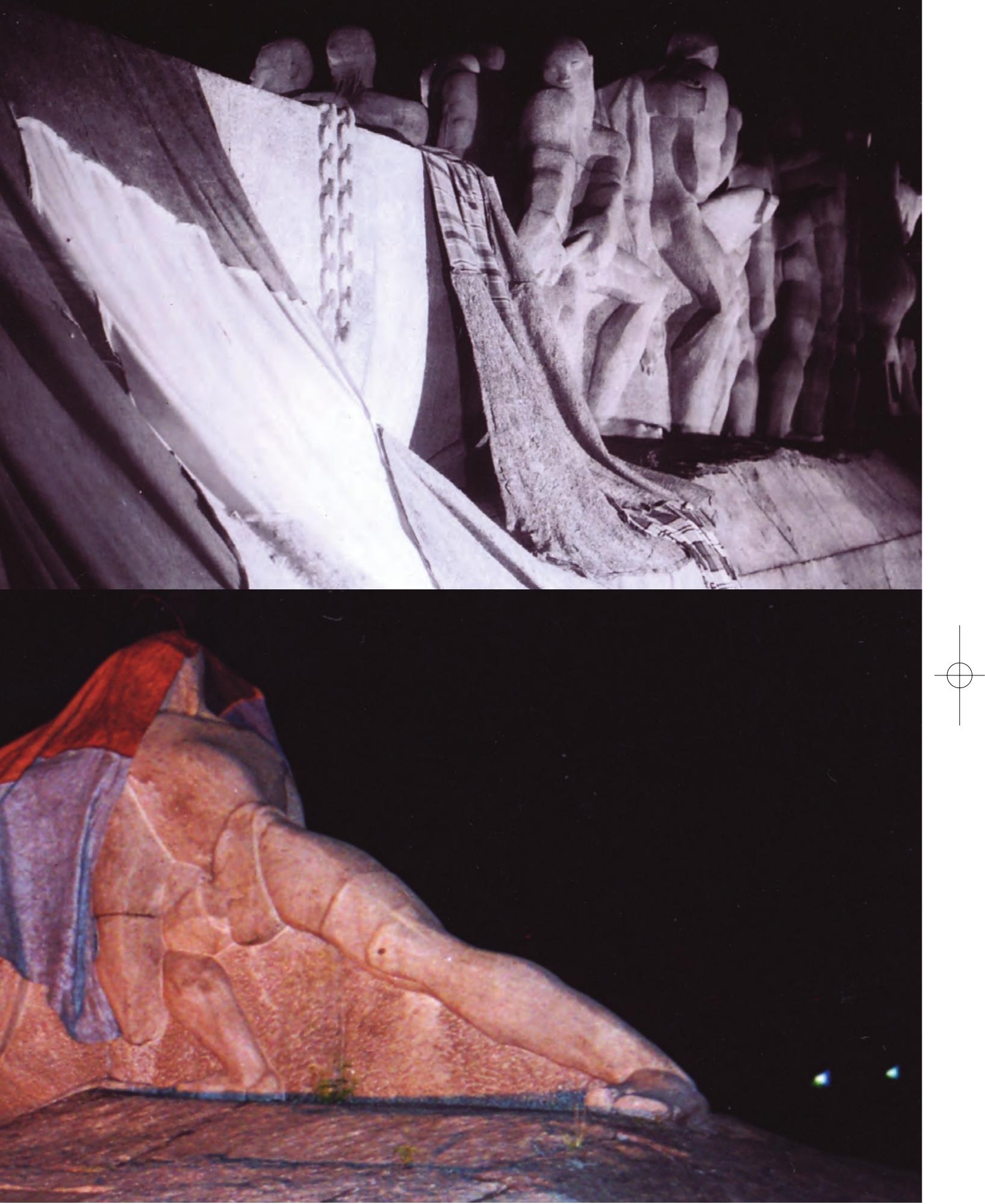


\begin{abstract}
dasse, definitivamente, a história das exposiçöes no Brasil: em vez de apresentar obras de arte da forma tradicional, resolvemos transformar cada um dos módulos da exposiçāo em um autêntico espetáculo cenográfico, a serviço da maior ênfase à beleza dos trabalbos expostos e da compreensão do seu conteúdo (200o, p.p. 20-2I).
\end{abstract}

Duas frases colocadas na rua, espalhadas em vários lugares da cidade, tentavam resumir aquilo que o grupo estava pensando e sentindo: "Chega de Mickey, 500 anos de $\mathrm{Mico}^{20 "}$ e "Chega de Bananalização ${ }^{21}$, 500 anos de Mico". Como parte de uma ação de protesto, o grupo foi à vernissage do evento com camisetas que continham estas frases, distribuiu para os convidados um manifesto e nessa mesma noite cobriu, com vários cobertores de homens de rua ${ }^{22}$, o Monumento às Bandeiras, de Victor Brecheret, localizado na frente do Parque do Ibirapuera, onde se encontra o Pavilhão da Bienal. E foi publicamente criticado pelos organizadores - que encararam o protesto como sendo um ato de "jovens baderneiros".

Apesar das ações do MICO indicarem o reconhecimento do processo de penetração do neoliberalismo no Brasil (e a atualização da colonização, o que não justificaria uma "celebração"), no manifesto $^{23}$ escrito pelo grupo vemos uma certa confusão conceitual: em alguns momentos, parece que se fala da arte como potência; em outros, a arte aparece mais como um objeto que deve ser reconhecido institucionalmente. Da mesma forma, se questóes políticas estavam claramente sendo acionadas, essas iam da reivindicação pelo "reconhecimento do artista” à representação cultural da história como renovação dos processos de sujeição.

20. Mico, em português, tem dupla conotação: é um macaco típico do Brasil e também expressa o ato de "pagar um mico", cometer uma gafe, ser objeto de ridicularização e vergonha.

21. "Bananalização" foi um neologismo inventado pelo grupo. No interior deste neologismo, temos: banana - um dos alimentos prediletos do mico - e banalização - que se referia à espetacularização de 500 anos de cultura e arte brasileiras, transformadas em fachada. 22. Roni Hirsh, um dos integrantes do grupo, havia feito um trabalho no qual trocou com homens de rua os seus cobertores usados por novos. Costurou todos os cobertores uns nos outros, formando um grande cobertor.

23. Este manifesto nunca foi publicado oficialmente, ele circulou na época em formato de flyer e faz parte do acervo do grupo. 
A intenção deste manifesto é tornar público nosso descontentamento com o projeto "Brasil +500 - Mostra do Redescobrimento". Dentro de uma exposição de arte, falar sobre arte é o mais importante.

Nessa exposição, a arte é rebaixada ao segundo plano e utilizada como pretexto para validar e vender um espetáculo cuja finalidade é o entretenimento. É inserida em um contexto onde tudo pode ser encenado, tematizado e transformado em objeto de interesse e observação turística, não artística.

Para que utilizar-se de outros meios para ativar a percepção que não a própria arte? Para que direcionar o olhar do público, enquadrar e delimitar em uma leitura única e linear através da ambientação cenográfica? A obra de arte fala por si mesma, não precisa da mediação de terceiros; as relações artista /obra/público devem ser livres, para que haja criatividade e enriquecimento dessas relações. O olhar, a percepção, são únicos para cada um e não únicos para todos. Não pode haver verdade oficial! $\mathbf{E}$, menos ainda, uma verdade que nivele por baixo: a cenografia apela para um choque, um susto perceptivo que fala mais alto e rouba espaço. A obra-de-arte em si vira objeto de cena!

Claro, somos a favor de um público mais numeroso, sempre. Somos a favor da ampliação do público, hoje restrito à elite cultural. Que se amplie o interesse pela arte; mas que a atitude, a vontade, a necessidade, partam do próprio público, para que, assim, haja uma relação efetiva. O interesse pela arte não pode ser induzido, como faz a propaganda de maneira apelativa - deve ser conquistado!

Não é possível que se concentre tanto dinheiro em um 
único evento-espetáculo. O diálogo público/obra-dearte deve se estender até o futuro e, para tanto, a arte não pode ser entendida como produto descartável, como mercadoria. Deve sim ser entendida como parte constituinte da cidadania, como alguma coisa à qual todos devem ter livre acesso e com a qual possam relacionar-se espontaneamente. Precisamos de melhores condições, inclusive para podermos produzir e consumir arte. O Brasil não é esse espetáculo!

A mostra do redescobrimento é, acima de tudo, reflexo da situação em que se encontra o País, funcionando de acordo com o mesmo sistema. Isso significa que, aqui, utilizamo-nos desta exposição como alvo, tomando o particular pelo todo. Não podemos mais admitir que sejam acobertados a dominação e os problemas políticos, econômicos, sociais e culturais que no Brasil sempre imperaram e imperam.

Este é um momento para refletirmos e transformarmos, não para nos acomodar e perpetuar a dominação. Acreditamos, inclusive, que não há sentido em comemorar os 500 anos sem parar para refletir: Por que 500 anos? Que 500 anos são esses? Comemorar significa considerar que nossa história, desde a colonização até hoje, é um sucesso? De quem?

A arte em si pode ser um meio para a reflexão e transformação. Sim, é fundamental que se invista na arte. Mas na arte enquanto sujeito, nunca enquanto objeto!

Grupo MICO, Abril de 2000 


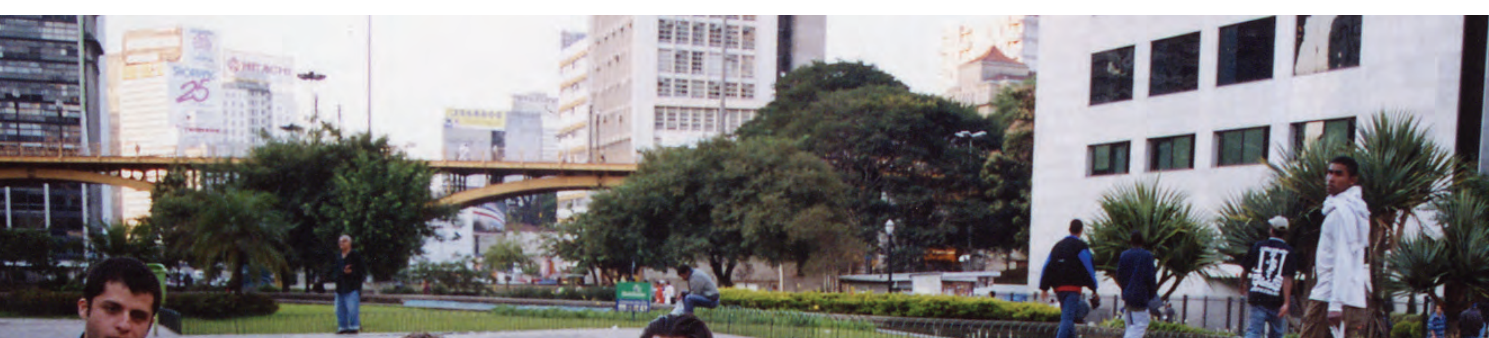

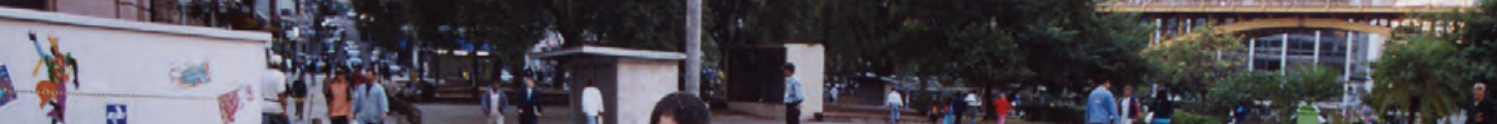

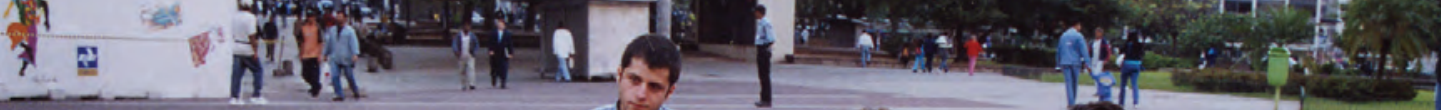

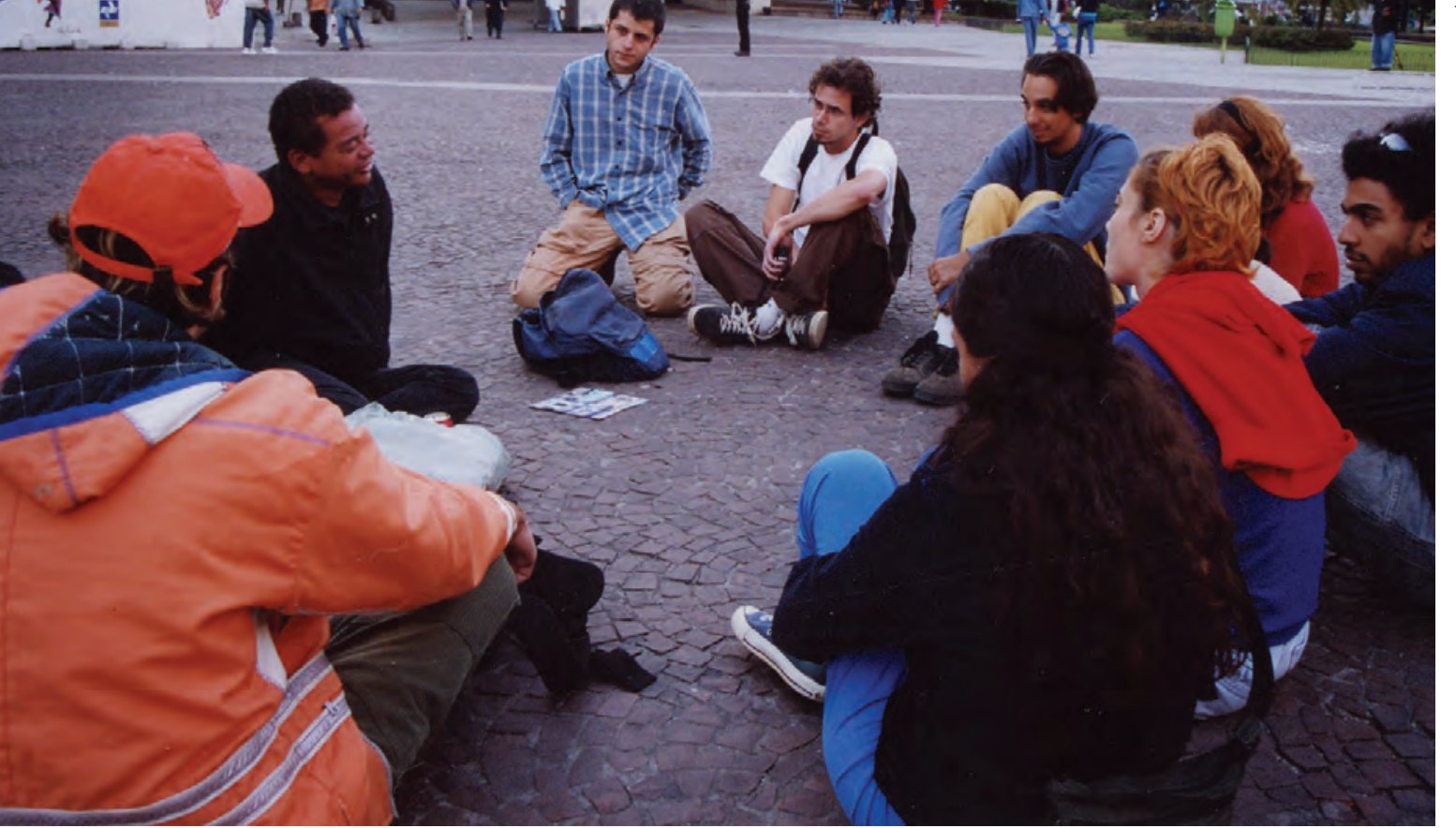

MICO em ação no Vale do Anhangabaú. A ação consistia em sentar em roda para conversar e interagir com transeuntes. São Paulo, 2001. 
A partir daí e mesmo com o fim da mostra "Brasil + 500", o MICO continuou se encontrando para realizar ações, sempre procurando criar situações de diálogo com intenção política, além de realizar inserçōes em circuitos ideológicos já legitimados ${ }^{24}$.

A experiência de cidade como espaço apropriável para a vida, gerou, no MICO, a descoberta de que era possível se comunicar através dela, transformando-a em mídia. Aos poucos, o grupo percebia que amigos comentavam aquilo que estava sendo colocado na rua. Nessa época, a principal forma de atuação do grupo era a produção de frases escritas em stencil em papel craft rosa, produção que se tornou a identidade visual do MICO. As pessoas perguntavam: "Foram vocês?". Esse mistério que tornava a cidade um corpo vivo e não um lugar de afirmação de identidades homogeneizantes ou egos, fez com que o grupo continuasse anônimo em suas açóes.

Apesar de hoje ser possível ver que ali já estavam sendo acionadas sensaçôes que depois seriam melhor compreendidas e desenvolvidas no próprio MICO e nas práticas artísticas que nasceriam como decorrência dele, há uma fragilidade perceptível, talvez pela própria natureza do momento, no qual a urgência do pensamento como ação artística ainda estava nascendo, tentando constituir-se enquanto voz e lugar no mundo, lutando para ganhar corpo. No entanto, já vemos ali fios condutores que depois seriam aprofundados, conceituados e vividos de formas cada vez mais complexas. $\mathrm{O}$ ato de romper com a sensação de isolamento crítico - no qual fazemos uma leitura dos fatos sociais de nossa atualidade, porém nos sentindo completamente incapazes de agir - foi uma espécie de "conquista", já que, como geração filha dos que enfrentaram a última ditadura militar brasileira, vivíamos ainda a memória do trauma de colocar o corpo em risco para o enfrentamento daquilo de que discordávamos. 
BANGOEANTRAL, DO HRY SIT:

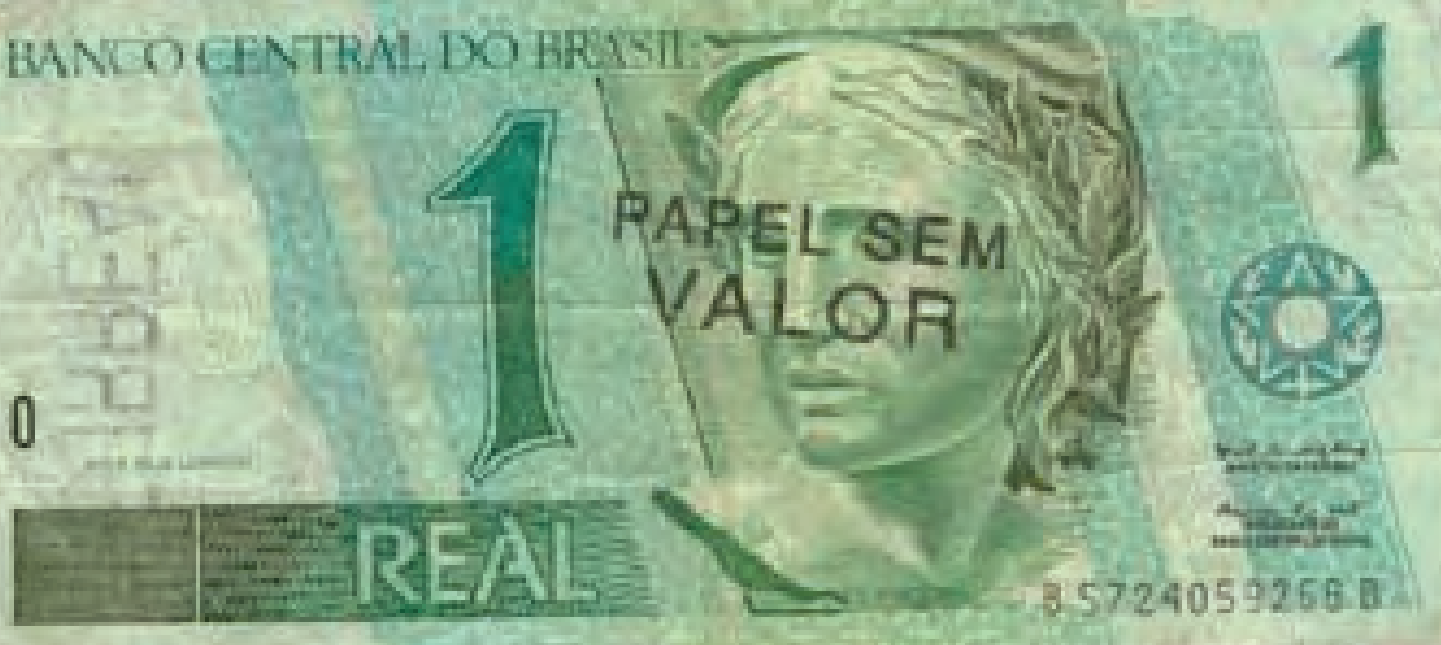

$4=-4$
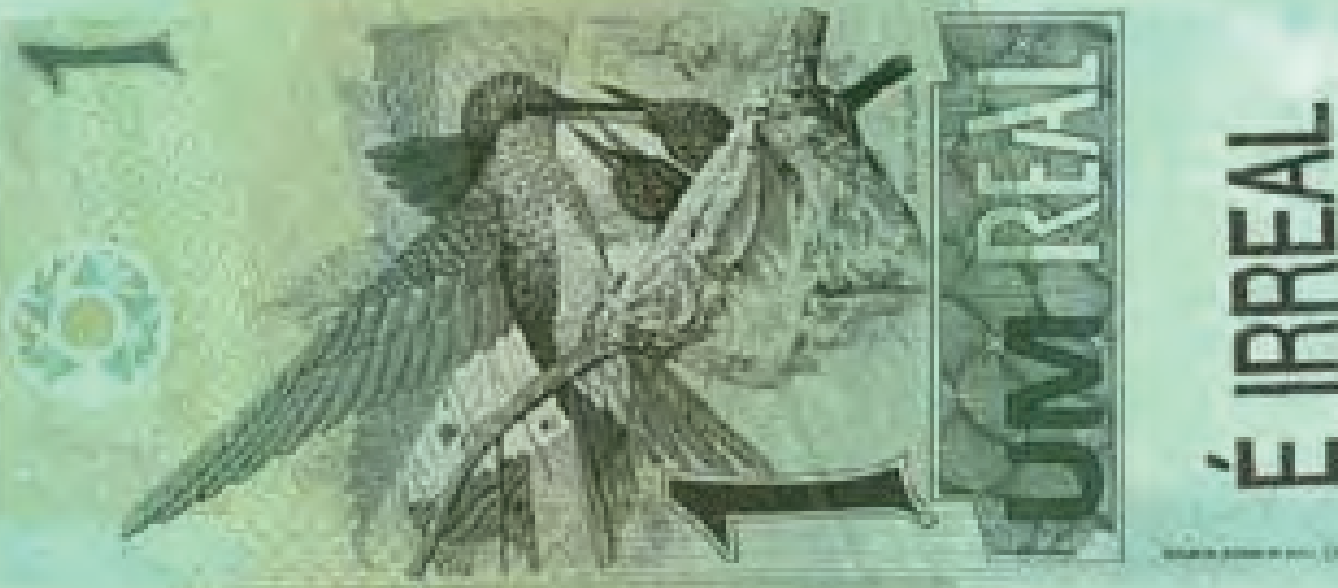

-H

ningtumpin
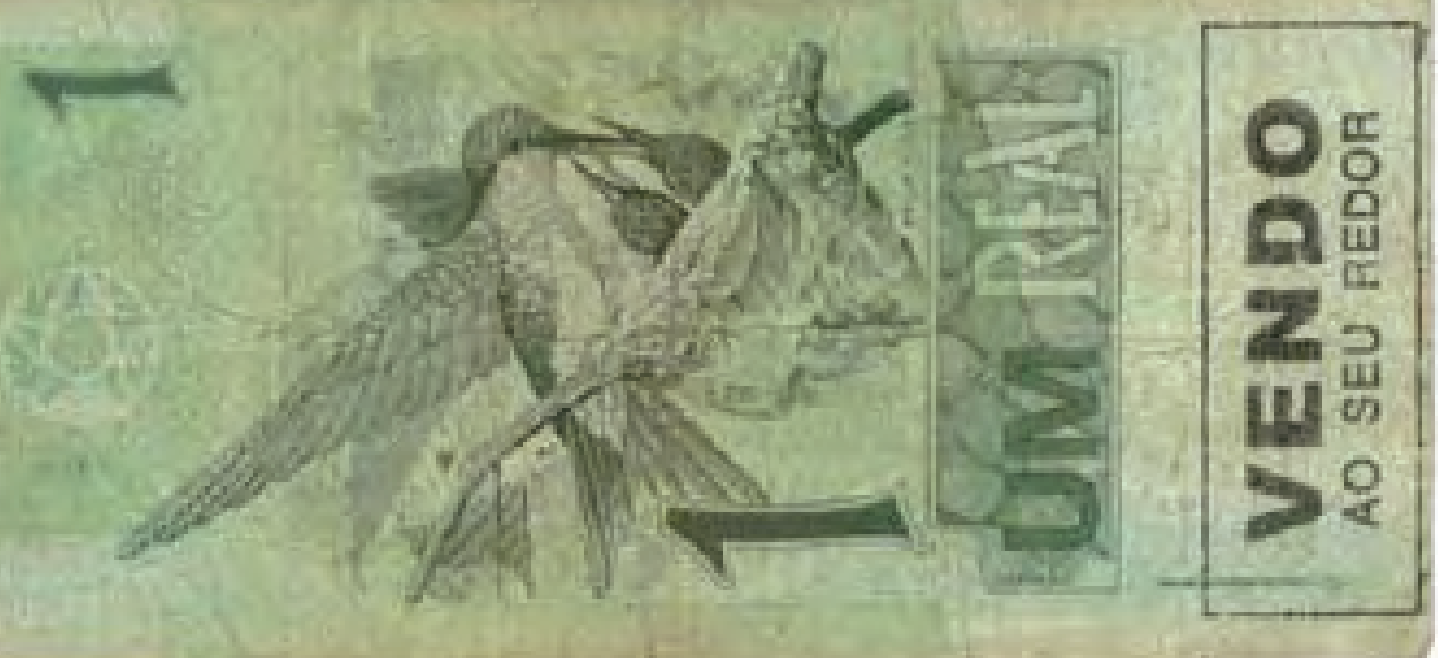
Portanto, libertar o corpo para a ação no espaço social foi um primeiro movimento de ruptura e descoberta de uma outra possibilidade de politização, que ao mesmo tempo em que reconhecia, traía a tradição; que ao mesmo tempo em que temia tornar-se um "corpo público", superava o trauma do silêncio forçado. Essa experiência inaugural emancipadora consistiu, entre outras coisas, da tentativa de elaborarmos, enquanto geração, a experiência de ter vivido sob um Estado totalitário, ainda presente tanto como representação ativa, quanto como memória corporal. O coletivo argentino GAC diz o seguinte sobre a sensação de potência que esse tipo de movimento por uma outra política de representação (que acionou o corpo e a cidade em primeira instância), despertou em nossa geração:

\begin{abstract}
Esa primera salida fue experimental en todo sentido: no sólo por los materiales que usamos - poco frecuentes para un mural-, también por el carácter ritual que envolvia la atmósfera de la acción, oscilando entre un acto performático y una improvisación cargada de elementos simbólicos, a un echo semiclandestino de toma del espacio. [...] Nunca antes habiamos producido desde la acción, es decir, colocando a nuestro propio cuerpo en acción en un lugar de enunciación. $\Upsilon$ al tiempo que descubríamos esta dimensión performática del hacer, y del hacer colectivo, íbamos modelando una forma de poder, de confíanza, de autosuficiencia (id. ibid., p. 125-129).
\end{abstract}

Acima, estão refletindo sobre as sensações causadas pela primeira ação feita por eles em I997: uma série de mais de trinta mu- 
rais nos quais usavam aventais brancos colados à parede com a consigna "Docentes Ayunando" (Professores Jejuando). Essa ação consistiu em criar uma potência coletiva e simbólica que dialogasse com a greve de professores por melhores condiçóes salariais e de trabalho. Segundo o GAC, ali estavam "[...] anunciando una tendencia a la no-representación. La idea no era representar una situación en el plano de la pared, sino crear una situación realla acción de ocupar la pared y el espacio [...]" (GAC, 2009, p. 28).

Vemos acima situações criadas pelo MICO e pelo GAC nas quais o corpo chama para si a possibilidade de reinvenção do espaço social quando experimenta-se a cidade como espaço aberto, não acabado e que responde às provocações. Percebemos nesse processo o desenvolvimento da compreensão do "urbano" ${ }_{25}$ como matéria prima e do corpo como potência que efetivamente singulariza, inventa e marca o espaço social. Um trabalho do GAC que parte da reivindicação por uma certa "ética do espaço comum" como um "espaço marcado pelo singular", foi "Ação Direta. Homenagem aos As' sassinados pela Repressão Policial na Rebelião Popular de 20 de dezembro de 20or". Nesse trabalho, os lugares reais da cidade de Buenos Aires nos quais pessoas foram assassinadas pela polícia, quando da rebelião popular (o "panelaço" argentino), foram marcados com uma lápide simbólica e um ritual de morte foi feito contando com a presença de familiares e amigos dos mortos.

Trabalho do GAC: Ação Direta. Homenagem aos Assassinados pela Repressão Policial na Rebelião Popular de 20 de dezembro de 2001.

25. Estou entendendo o urbano como espaço vivo e complexo, constituído por diversas camadas de vida, meio de produção, forma trans-histórica (por condensar as múltiplas temporalidades presentes no contemporâneo) e campo de forças no qual se espacializam as diversas escalas de poder (ver capítulo 2). 


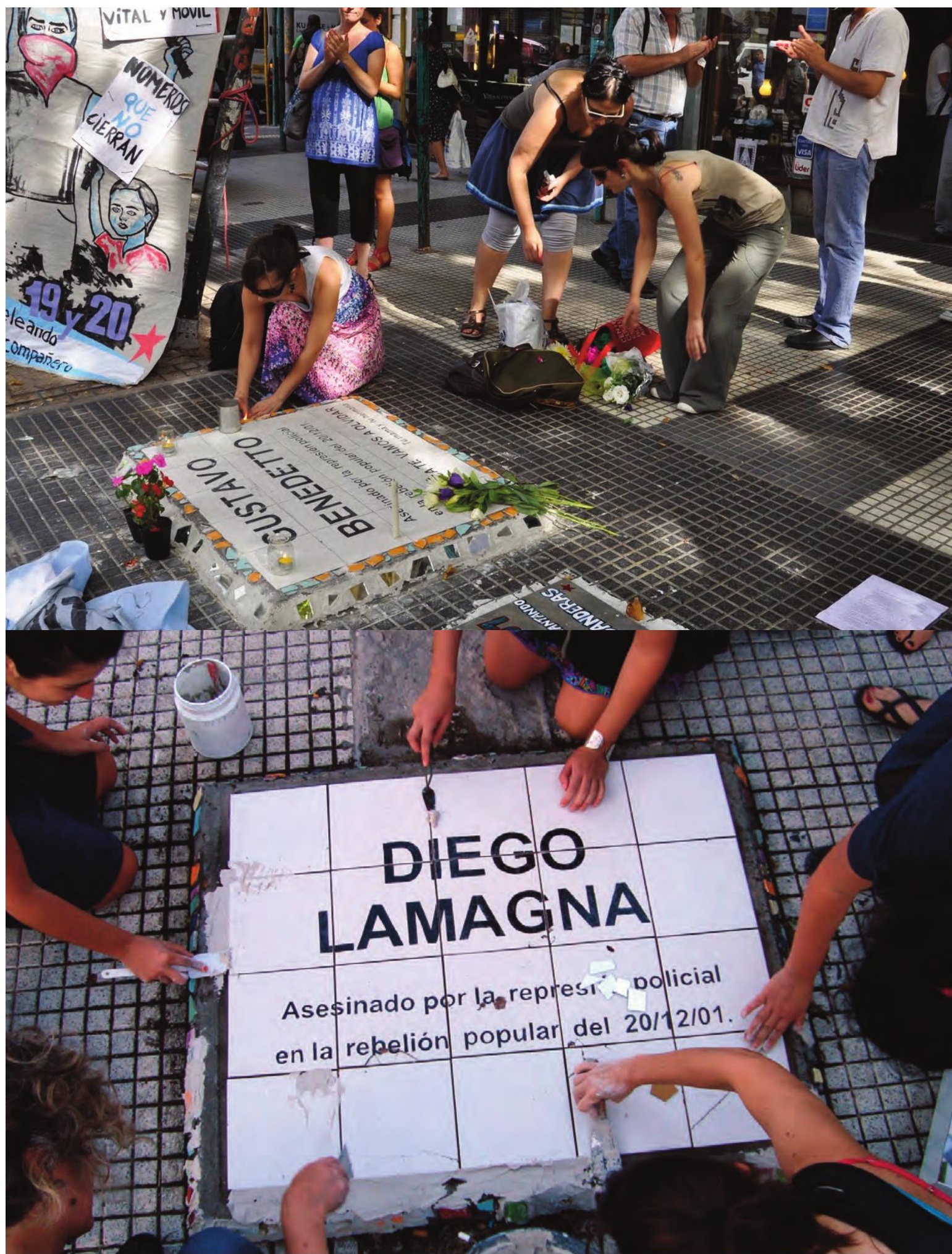




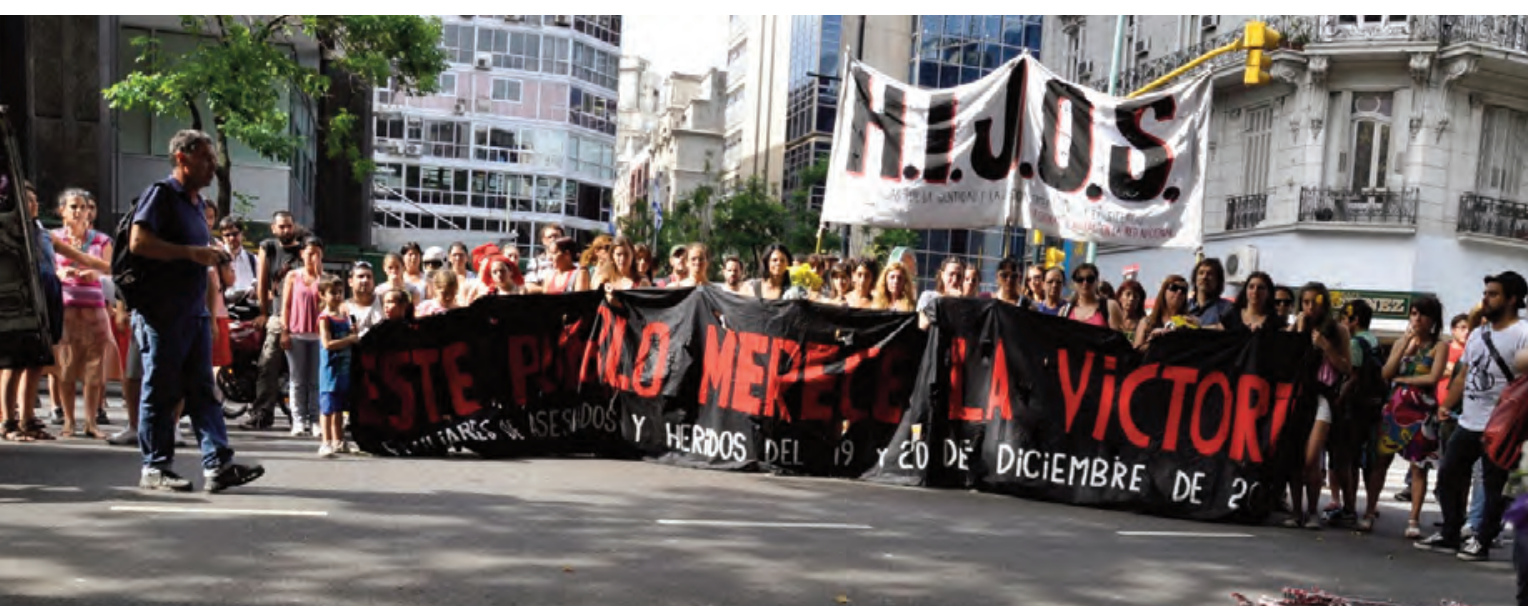

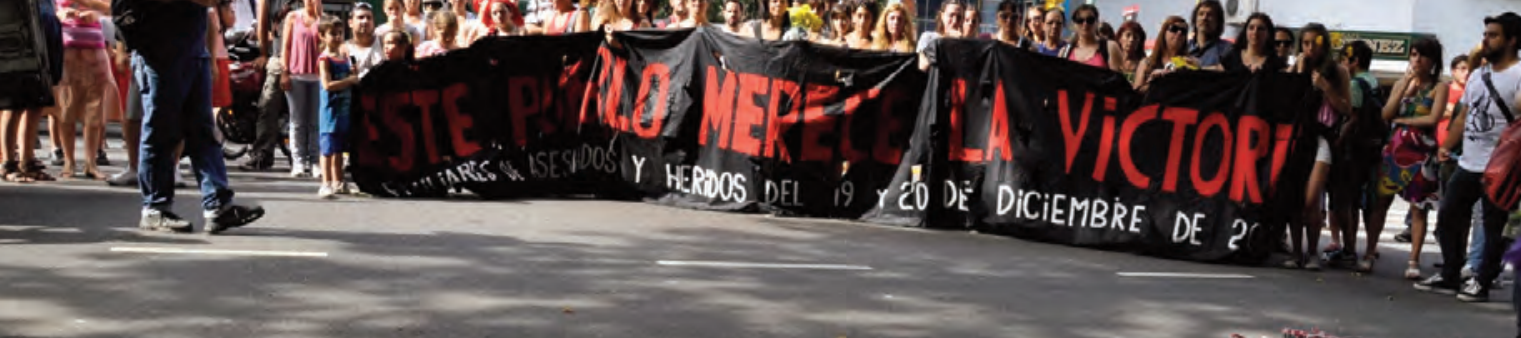

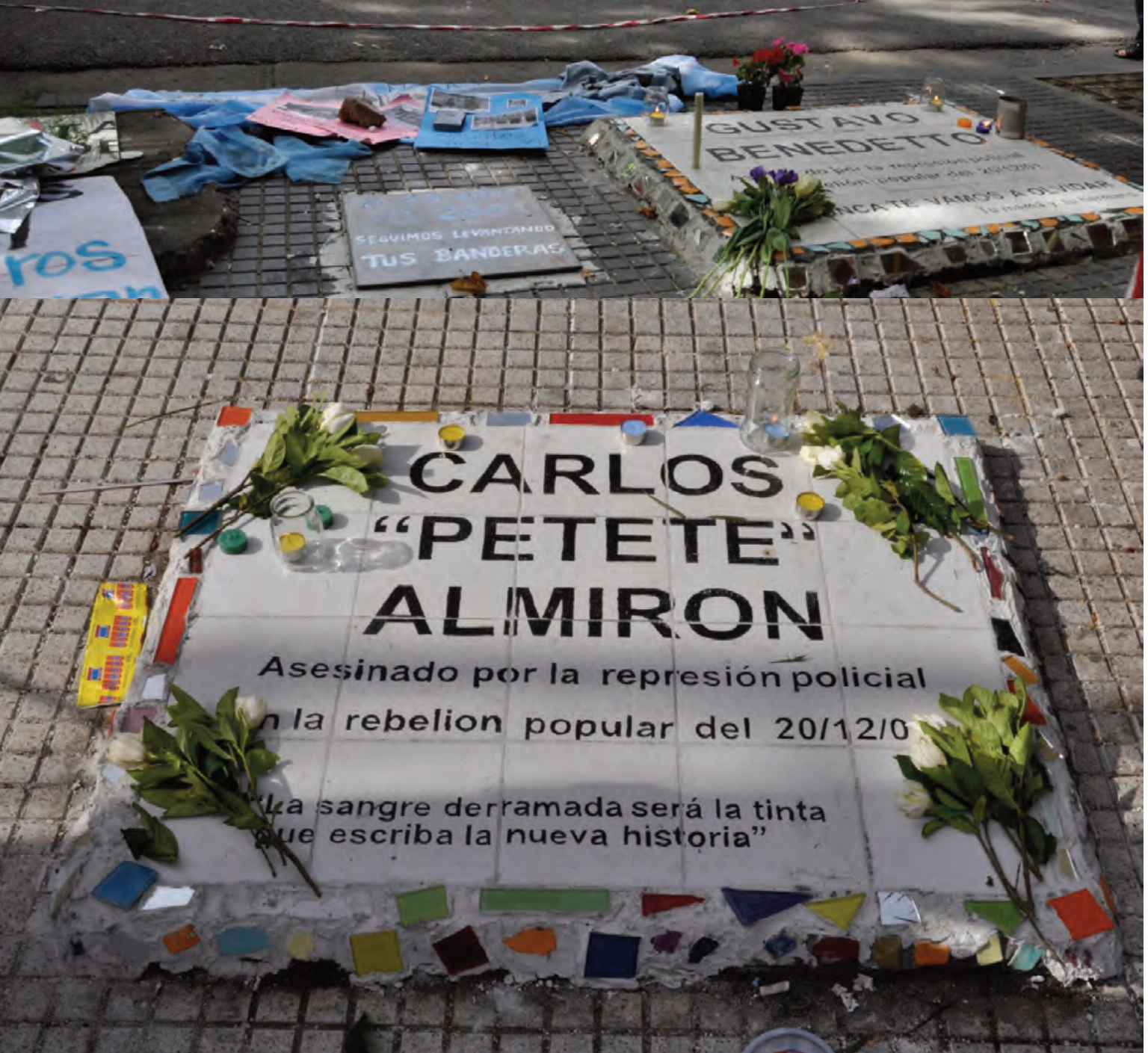




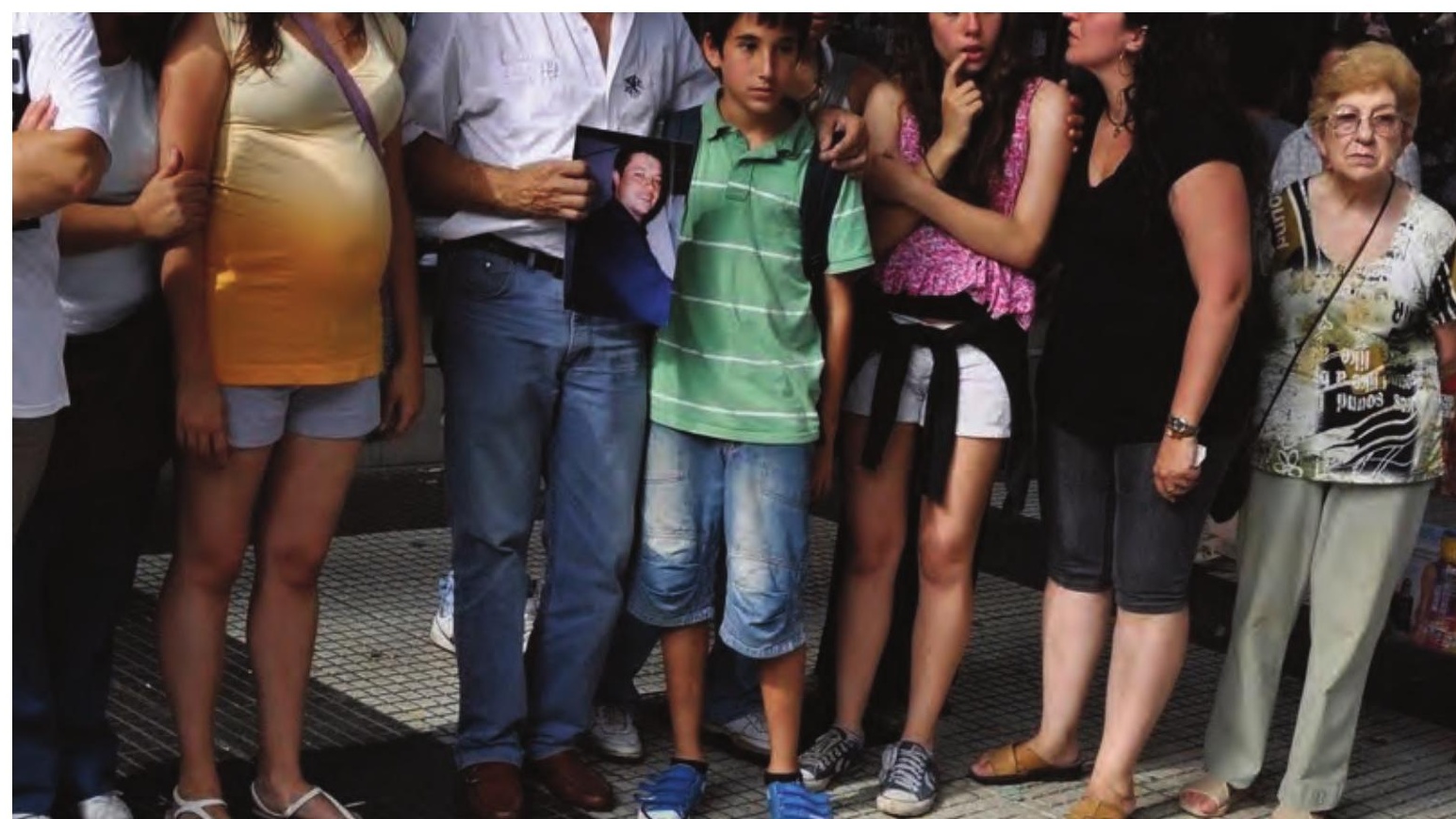

- n

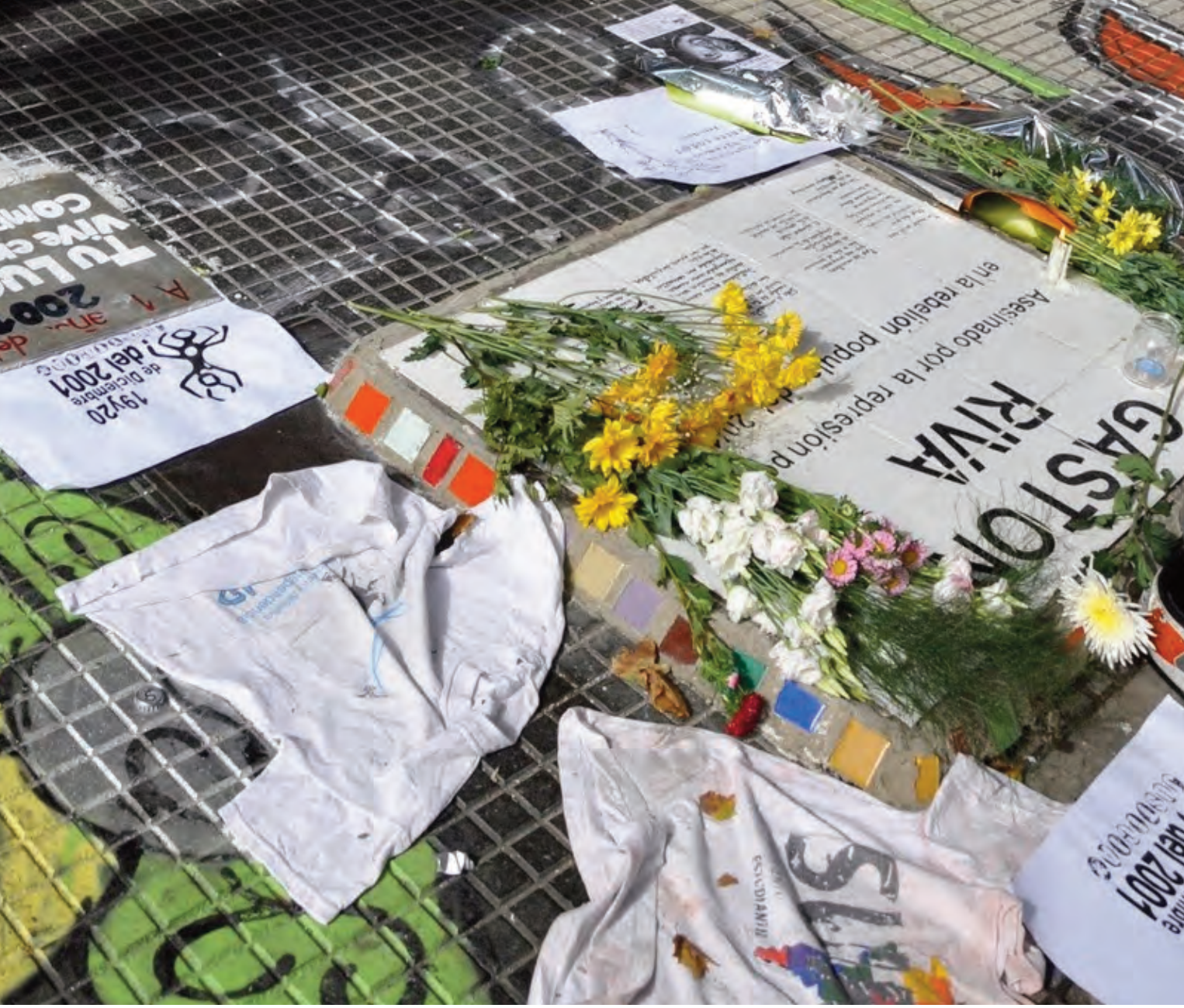


ats.

an

vin: tent:

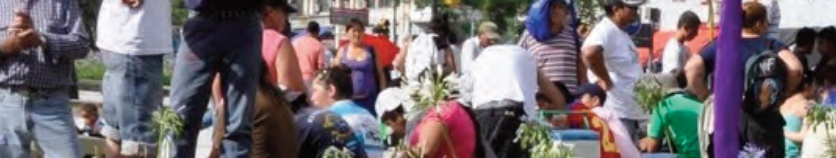

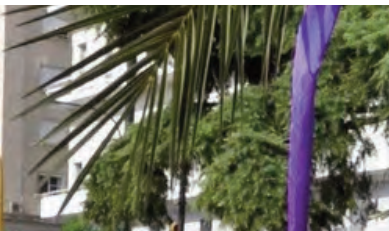
2.10 31740.4 1HW 1. H 2. . . T.?

ancises

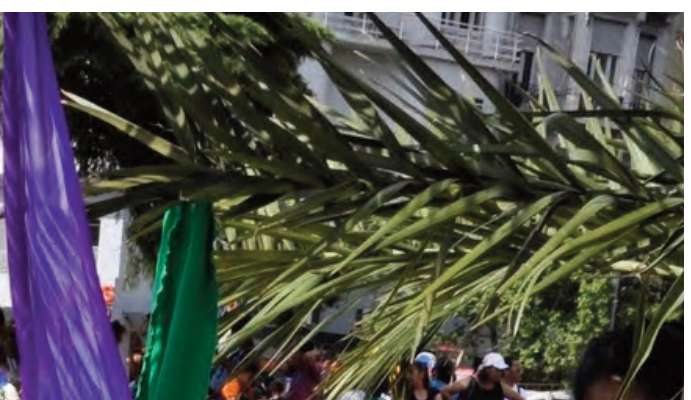
(4)

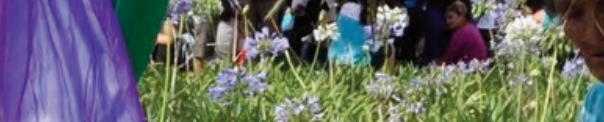




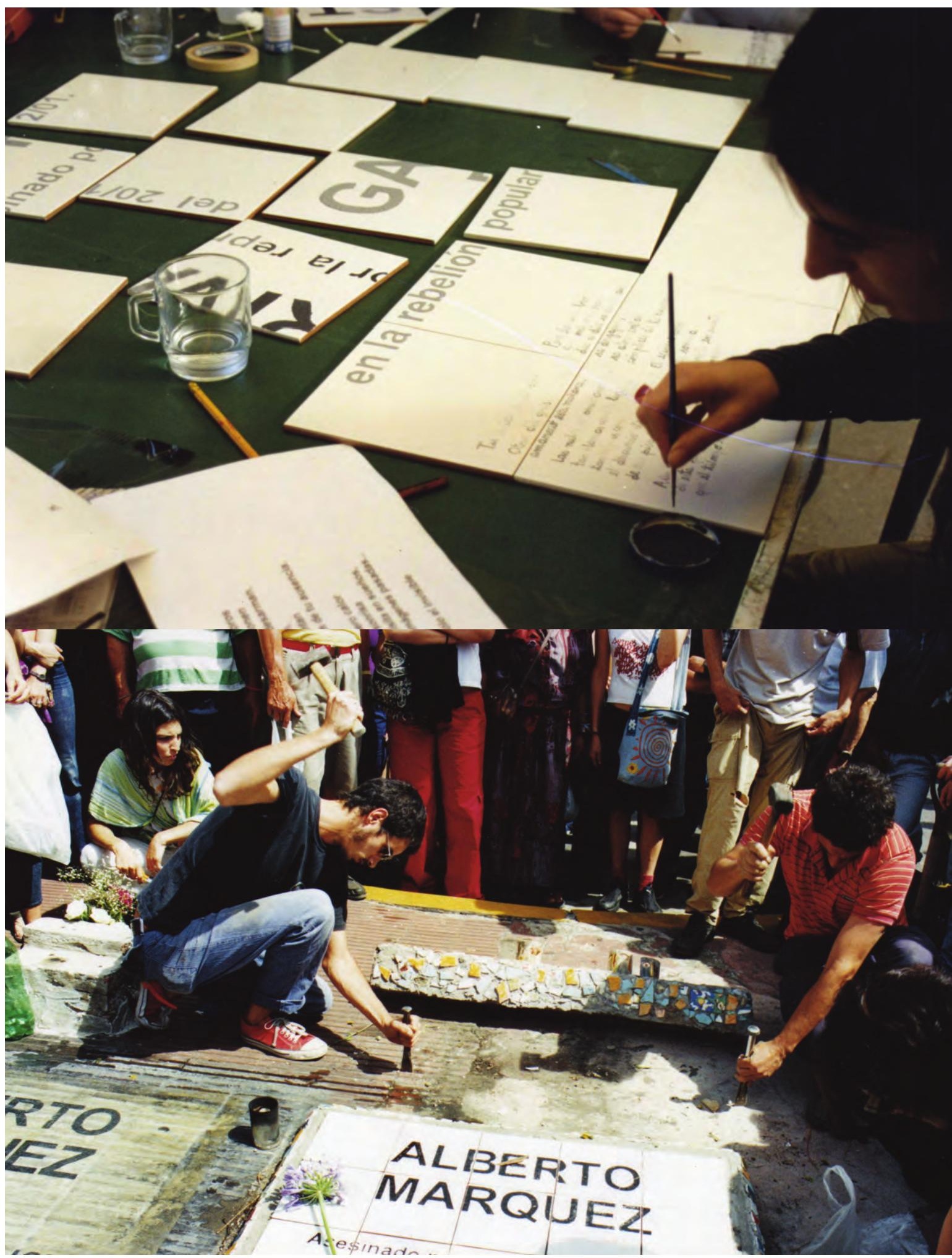


El fin de los homenajes era irrumpir en el espacio aséptico de la historia. Dejar una buella, una señal, una marca. Hacer del lugar del espacio urbano diseñado para el no lugar, el lugar con su memoria, hacerla presente activamente, reactualizarla, señalarla. Apelar con una voz disidente, construir un espacio que abra y no solidifique los sentidos, denunciar la muerte de los manifestantes en el mismo lugar del hecho y la autoría de la fuersa policial y parapolicial. Se realizaron placas con la estética de los recordatorios populares y un recorrido en el que se leía un texto que denunciaba los nombres de los responsables de los asesinatos y sus prontuários; también se recordaba a cada uno de los asesinados con una breve biografia" (GAC, 2009, p. 138). 


\section{Não estamos em rebelião: notando na hegemonia a diferença}

Quanto mais a construção desse espaço de politização aumentava a confiança para a leitura crítica da realidade e para a ação direta na cidade, mais o grupo MICO se permitia ir a fundo nas questóes que o atravessavam. Foi quando explodiu a primeira grande rebelião nos presídios do Estado de São Paulo em 200ı. Aquilo chamou a atenção do MICO, já que tinha como uma de suas estratégias partir dos fatos sociais que de alguma forma condensavam a "experiência crítica do conflito", ou seja, que representavam, enquanto experiência pontual, a potência de um conflito social mais profundo.

Hoje, é possível entender esse conflito, sempre mencionado pelo grupo, como o próprio conflito entre a experiência do mundo que atravessava os nossos corpos e as representações construídas, essa lacuna entre aquilo que vivíamos como real e o que se apresentava como o discurso dominante sobre "a realidade".

$\mathrm{O}$ que significavam todos aqueles presos em rebelião? Sendo a primeira vez que vinha a público a existência do PCC (Primeiro Comando da Capital), do que estavam falando quando mencionavam uma luta por direitos humanos dentro das prisóes? Que imagens eram aquelas de lençóis brancos nas janelas dos presídios? Quem colocou os lençóis, o PCC ou os outros presos, não ligados à facção?

Mas foi a frase "Não estamos em rebelião, queremos nossos direitos, paz”, escrita no chão do pátio do presídio pelas mulheres e parentes dos presos, que disparou a necessidade radical ${ }^{27}$ [Agnes Heller, 2004] da ação. No meio da maior rebelião em presídios de que se tinha notícia no Brasil e no mundo, os presos, como grupo organi- 


\section{4 presídios se rebelam em SP}

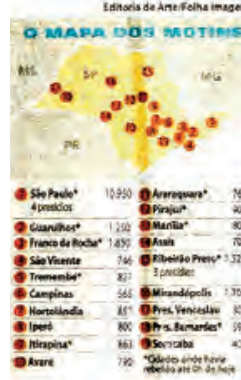

Temos medo de morrer, diz preso ¿ABRIELA ATHIAS IAREPORTASEMLOCAL

A Folha falou pelo celular :om um preso da Penitenciária to Estado. identificado como "Tio". Segundo ele, houve nortes no pavilhằ 1 do presilio após a sarda das visitas. Folha - O Batalháo de Choque ja nvadiu o pavilhiso 27

Tio- Ís mas as visitas continuam lqui. Se elas saírem, a gente tem
nedodemorrer.

Cerca de 27 mil presos belaram simultaneamen 24 presidios de 19 cidades
listas, Os motins comec ontem à tarde, no com
ontas, Os motans comec penitenciário do Cara (zona norte de São Paulo Penitenciária do Estado dois presidios, 9.700 pre visitantes. A Penitendín minina, também no Ca ru, teve 500 presas rebelac Segundo a Polícia Mil motivo das rebelióes transferencia de cinco acusados de liderar o Capital) de Sào Paulo Taubaté, na última sex PCC é uma facçấo crim surgida nos anos 90 e ac de tráfico de cirogas, assa tos e extorsóes de detent penitenciainas paulistas. Até as $23 \mathrm{~h} 30$ de onte viam sido contabilizado
mortos e nove feridos. A as direçóes de 11 presídio firmaram que as rebelio vam controladas. Os continuayam em outros cluindo o Carandiru, or pessoas foram liberadas nal da noite.

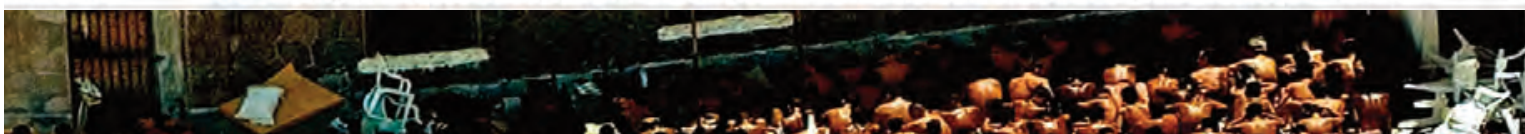

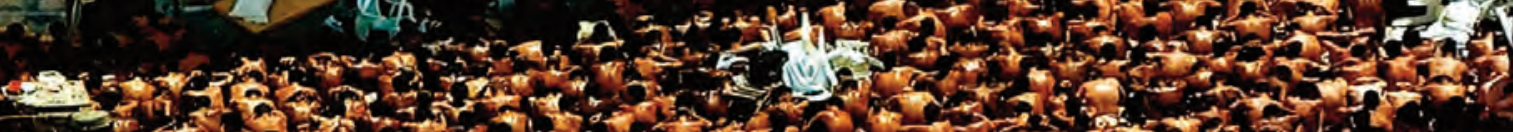

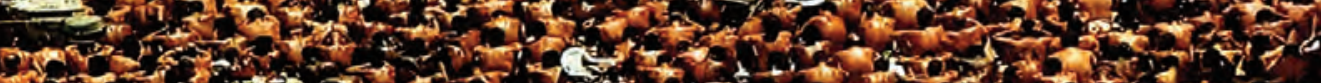

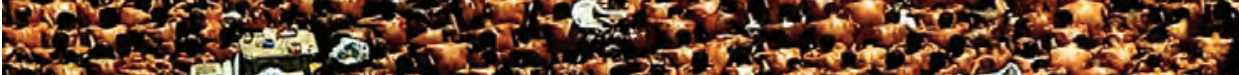

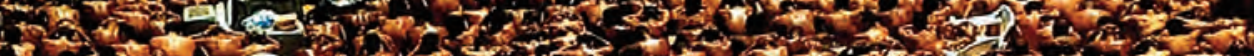

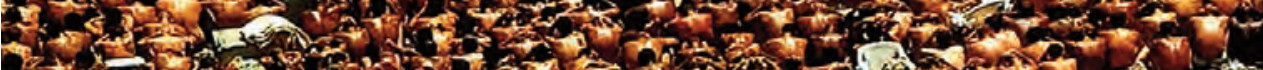

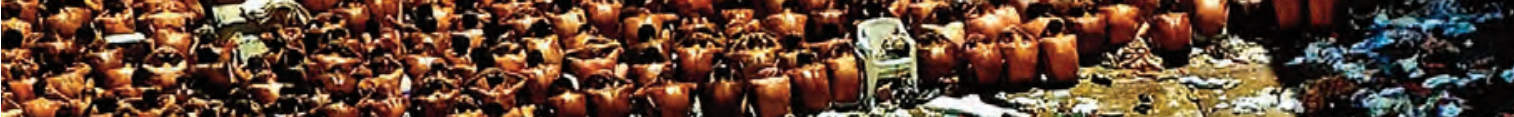

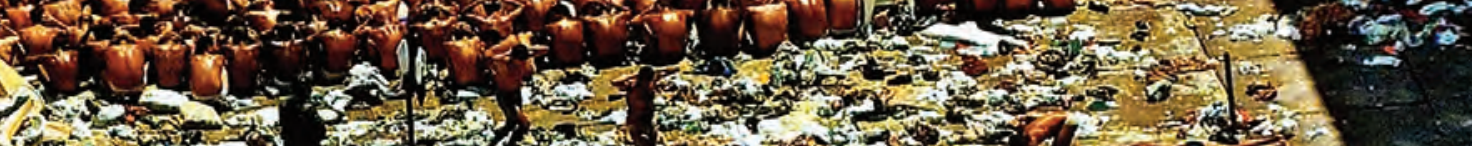

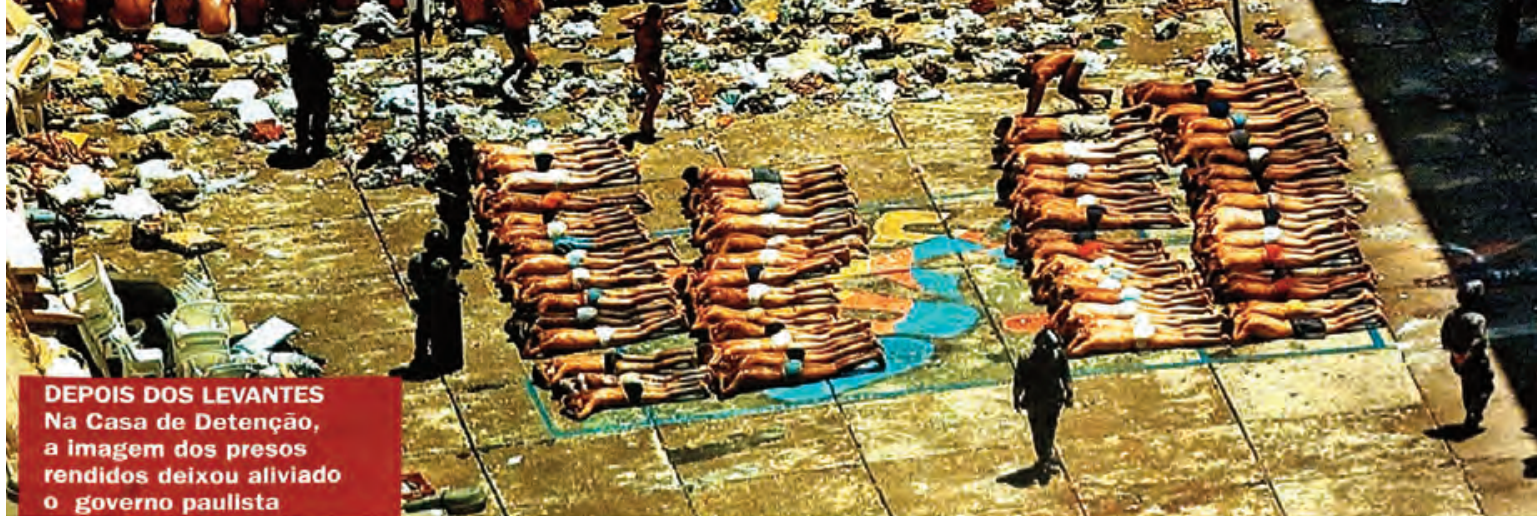






ATO PACIFICO Parentes de presos protestam por melhore cerca de 300 pessoas, incluindo 50 crianças, dormiram no local 
zado, afirmavam não estar em rebelião. Estrategicamente, criavam ali uma forma de denunciar para o mundo a sua situação, sabendo que helicópteros não teriam como não registrar aquela imagem.

Como diziam, na época, os integrantes do MICO, "algo explodia na imagem", algo que não estava sendo dito claramente pelo discurso verbal. Agora, refletindo sobre isso, percebo que houve ali o reconhecimento da própria linha de fuga ${ }^{28}$ do "fato anunciado", de algo que escapava ao discurso estratificado. Dentro do grupo, essa sensação de deslocamento causada pela imagem, se traduzia em algumas perguntas: será que não existem diferenças, nuanças e subjetividades compondo essa rebelião? Ou o que vale é apenas a interpretação que a reduz a um "corpo único, homogêneo e criminoso"?

A partir disso, uma questão que se colocou para o MICO e que também foi sendo, depois, aprofundada como um dos eixos de trabalho mais contundentes de alguns coletivos artísticos, era a prontidão para detectar e agir em relação à falta de consistência decorrente de representações binárias hegemônicas (nós somos os bons, eles são os maus e perigosos), que transformam fatos sociais $\mathrm{ex}^{-}$ tremamente complexos em estereótipos esvaziados de experiência. Como escreveu o MICO, na época, sobre esse acontecimento:

\section{Víamos ali uma lacuna no discurso oficial. Os tex- tos da imprensa eram acusatórios e não levavam em conta a complexidade do fenômeno. Isso tornava-se evidente nas fotografias que acompanhavam estes textos, onde apareciam manifestações dos presos. Com a intenção de apontar a existência desta lacuna e questionar a função social da imprensa, deslo- camos a frase do jornal para a rua. No dia seguinte,}

28. Utilizo aqui linha de fuga na acepção de Deleuze e Guattari: "Todo rizoma compreende linhas de segmentariedade segundo as quais ele é estratificado, territorializado, organizado, significado, atribuído, etc; mas também compreende linhas de desterritorialização pelas quais ele foge" (Deleuze e Guattari, 2004: 18). "[...] O rizoma se refere a um mapa que deve ser produzido, construído, sempre desmontável, conectável, reversível, modificável, com múltiplas entradas e saídas, com suas linhas de fuga" (Deleuze e Guattari, 2004, p. 32-33). 


\section{a frase apareceu novamente na Folha de Säo Paulo: "PCC espalha faixas pela cidade. ${ }^{29}$}

A reportagem da Folha ligou para um dos líderes da facção e perguntou se tinham sido realmente eles que haviam colocado as faixas nas avenidas Sumaré, Rebouças e Consolação. O líder não só confirmou, como disse que o objetivo era "negociar em paz com o governo" e que seriam colocadas faixas em diversos bairros da cidade.

Cabe aqui ressaltar que o viaduto no qual foi colocado o lambe-lambe depois fotografado pela imprensa ${ }^{30}$, tinha sido utilizado outras vezes pelo MICO, sendo considerado pelo grupo como um lugar com "boa visibilidade", já que amigos do grupo que eram jornalistas e moravam ali perto sempre perguntavam, quando frases eram colocadas lá: "Foram vocês?" Essa é uma dimensão estratégica nesse tipo de trabalho, pois tanto o contexto a partir do qual, quanto o contexto no qual a intervenção é feita são igualmente importantes para a proliferação da vontade disparadora da ação. Quando se fala em práticas situadas, é, justamente, no sentido de evidenciar a forte presença do espaço material como parte fundamental da constituição e circulação simbólica do acontecimento.

No plano macropolítico, o deslocamento de uma frase do contexto de esvaziamento crítico do jornal para o espaço do acontecimento urbano, gerou certo pânico social pelo fato do PCC não estar apenas dentro, mas fora da prisão; e debates sobre o significado de "direitos humanos dos presos" começaram a aparecer nos meios de comunicação, com especialistas falando sobre o assunto. Além disso, ao evidenciar a relatividade da "verdade oficial", a própria intervenção serviu como prova da simplificação do fenômeno social pela grande mídia.

29. Registro interno do grupo, arquivo pessoal.

30. O viaduto mencionado é o da Rua Oscar Freire, na altura em que esta atravessa a Avenida Sumaré. O lado com maior visibilidade é o que dá para ser visto de dentro da Estação Sumaré do metrô, na qual as paredes são feitas de vidro. 


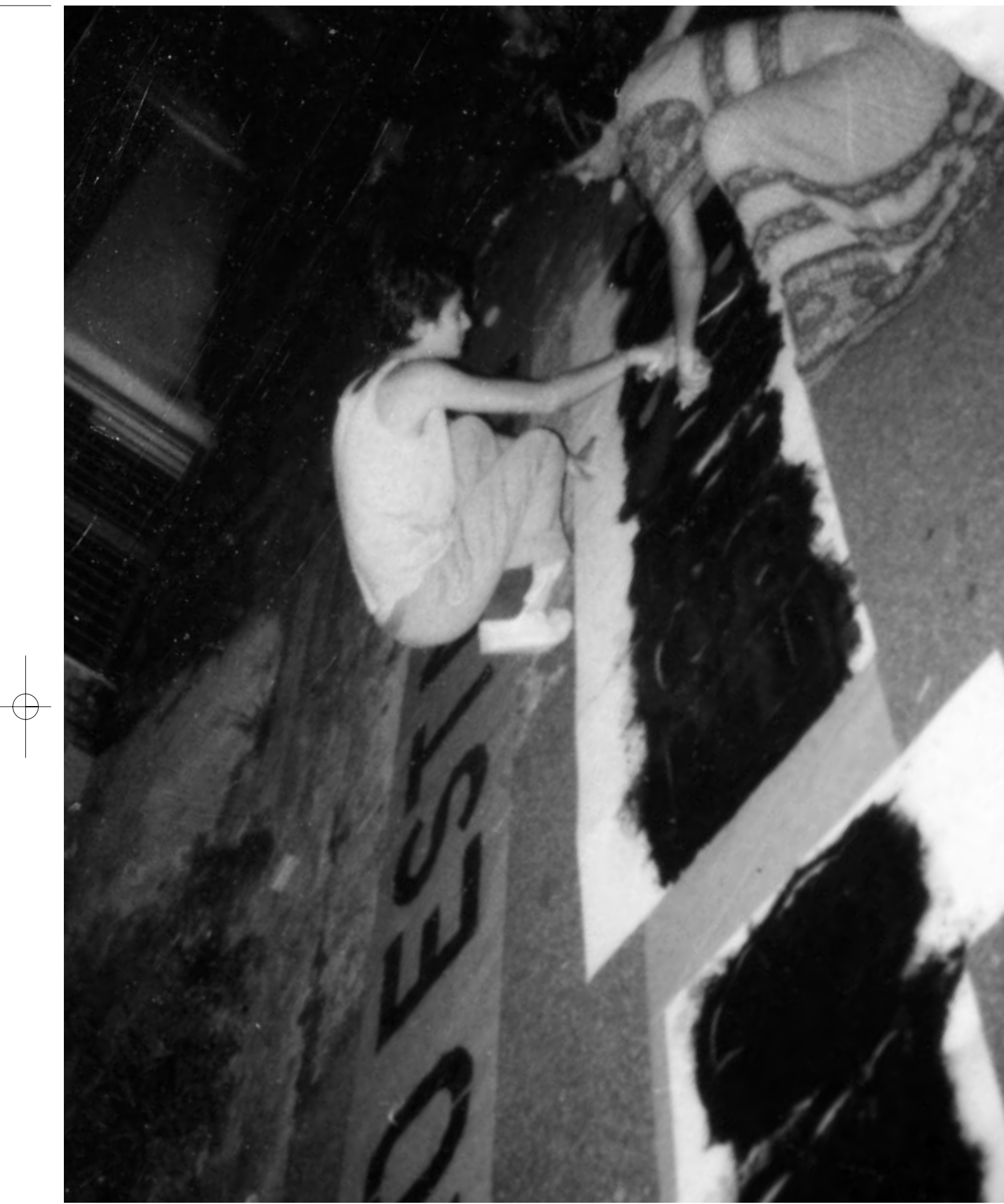

MICO pintando faixa com a frase "Não estamos em rebelião...", São Paulo, 2001. 


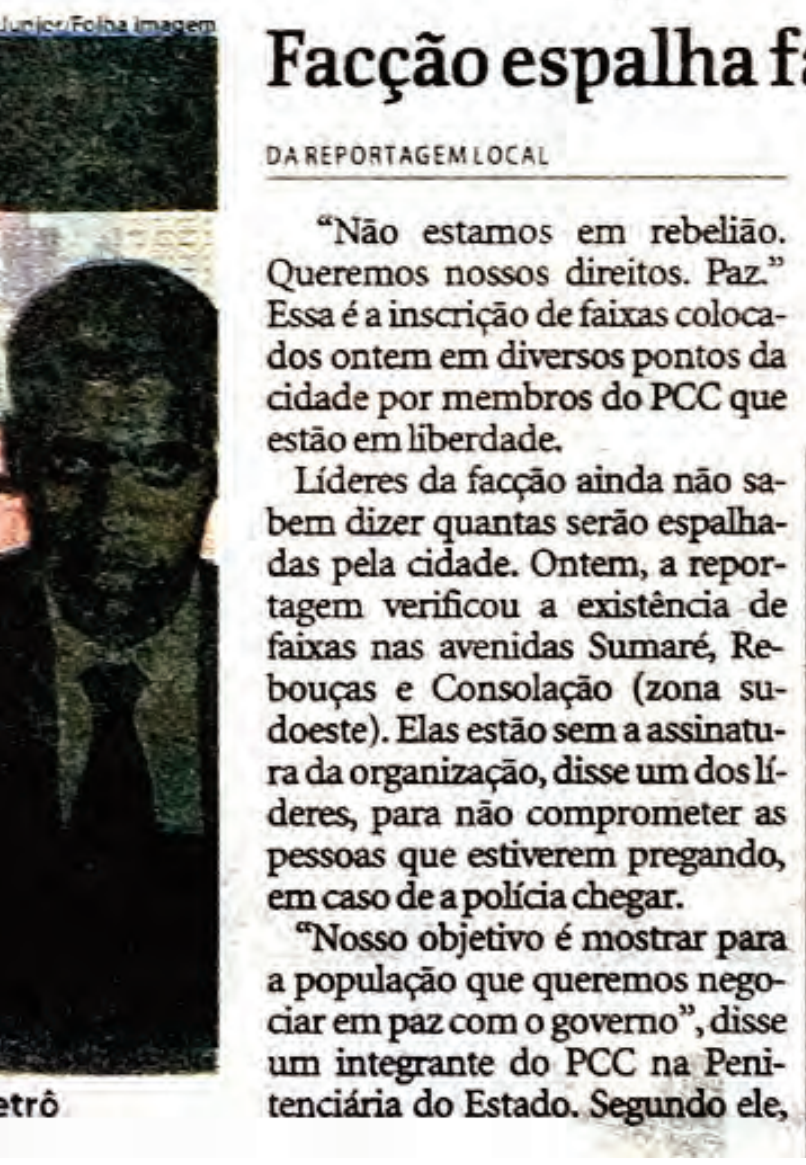

\section{Facção espalha faixas pela cidade}

serāo colocadas faixas em vários bairros. Ontem à noite, a assessoria de imprensa da Secretaria da Segurança disse desconhecer a existência das faixas. Só hoje vai pronunciar sobre o caso.
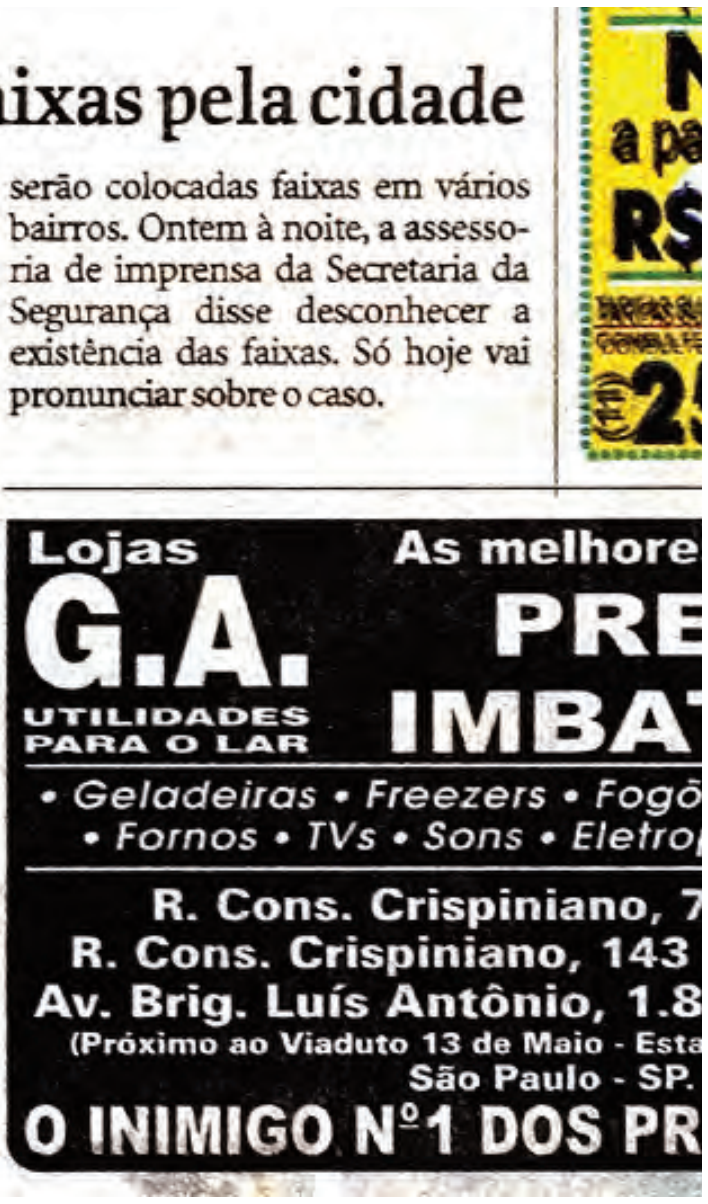

Repercussão do deslocamento da frase "Não estamos em rebelião..." pelo MICO,

Folha de São Paulo, 2001. 


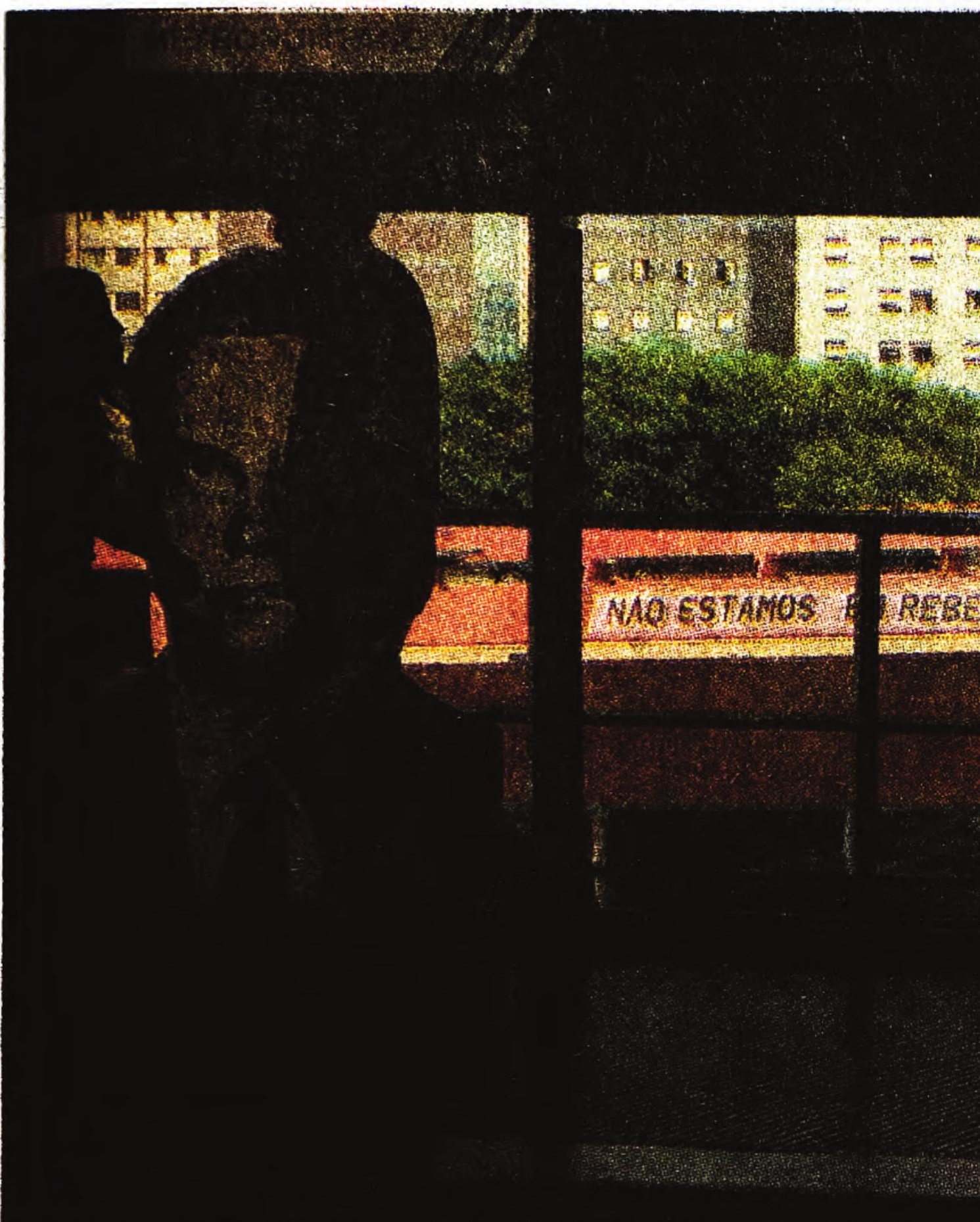

\section{Faixa do PCC na avenida Sumaré (zona sudoeste}




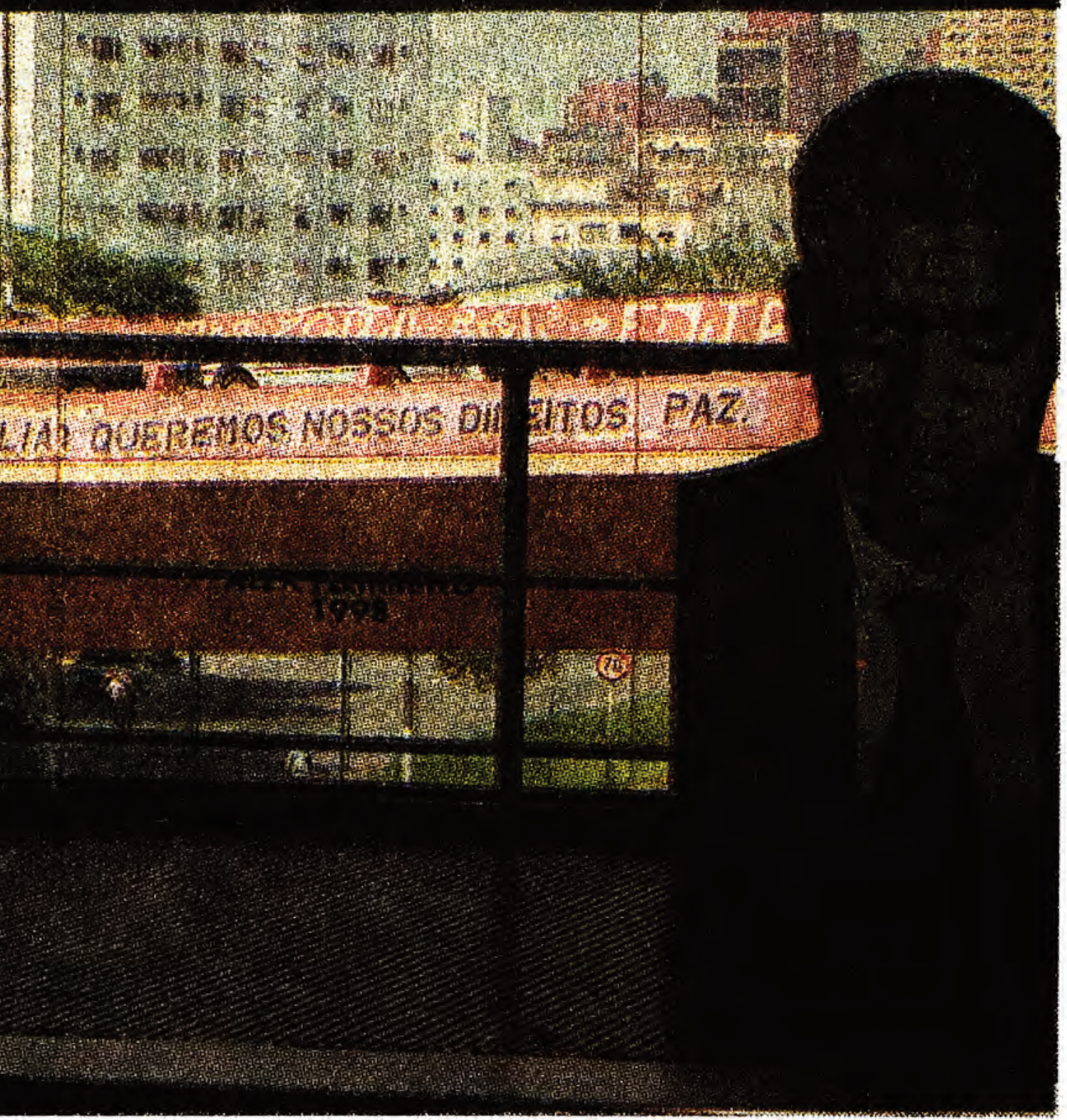

de São Paulo), vista da estação de metrô 


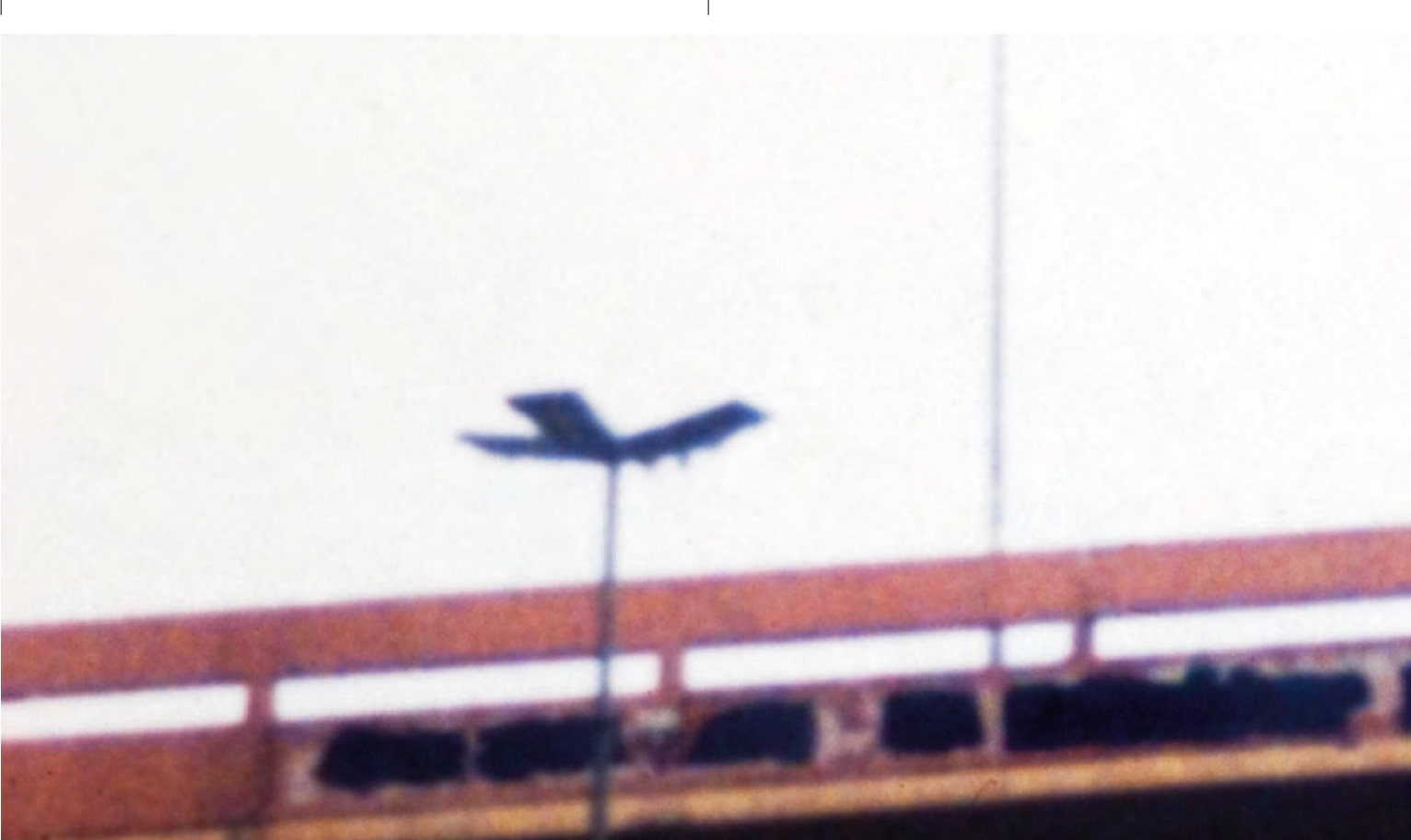

Frase "Não estamos em rebelião..." pintada de preto após ser noticiada como do PCC, São Paulo, 2001. 


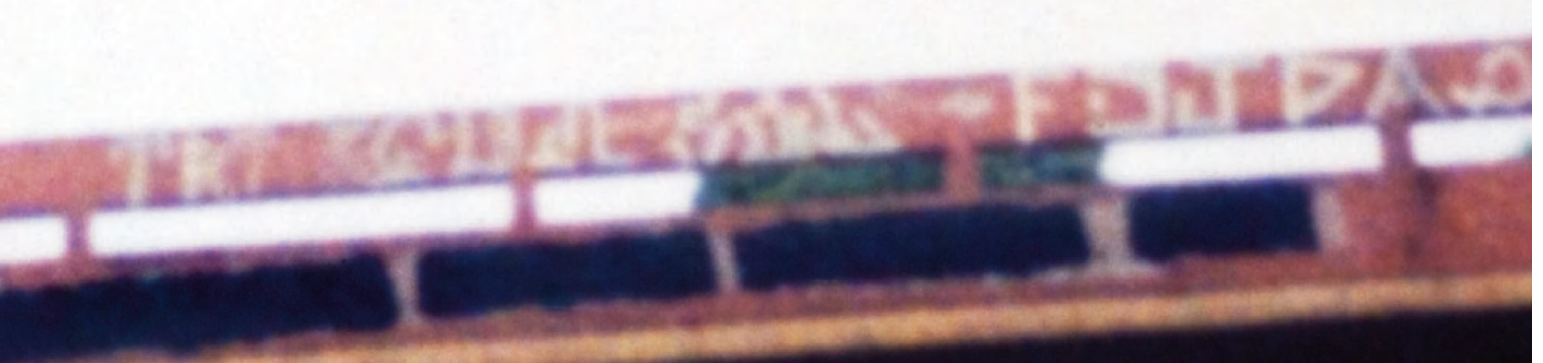




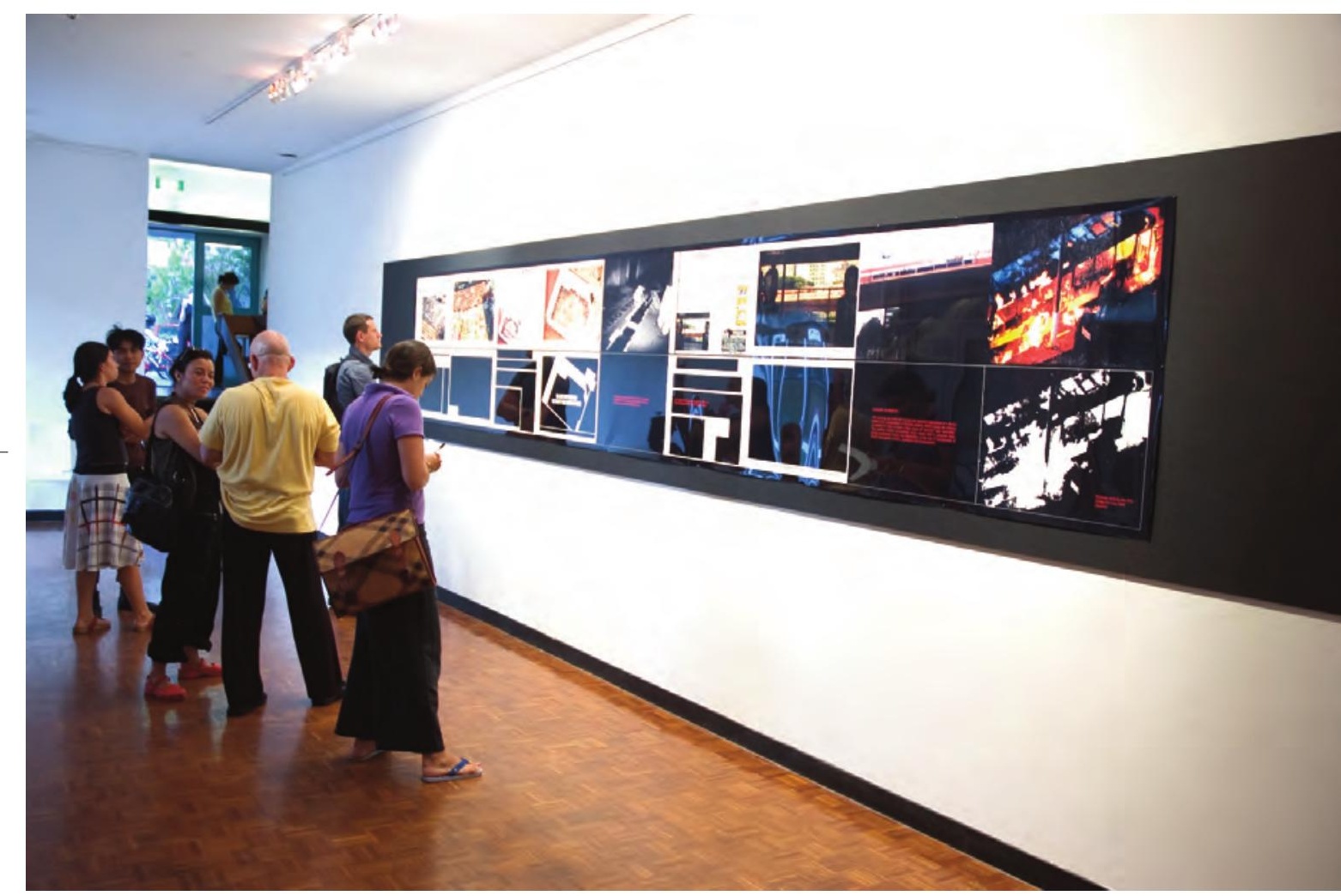

Trabalho do Contrafilé na Chrissie Cotter Gallery, Sydney, Austrália, 2007. 


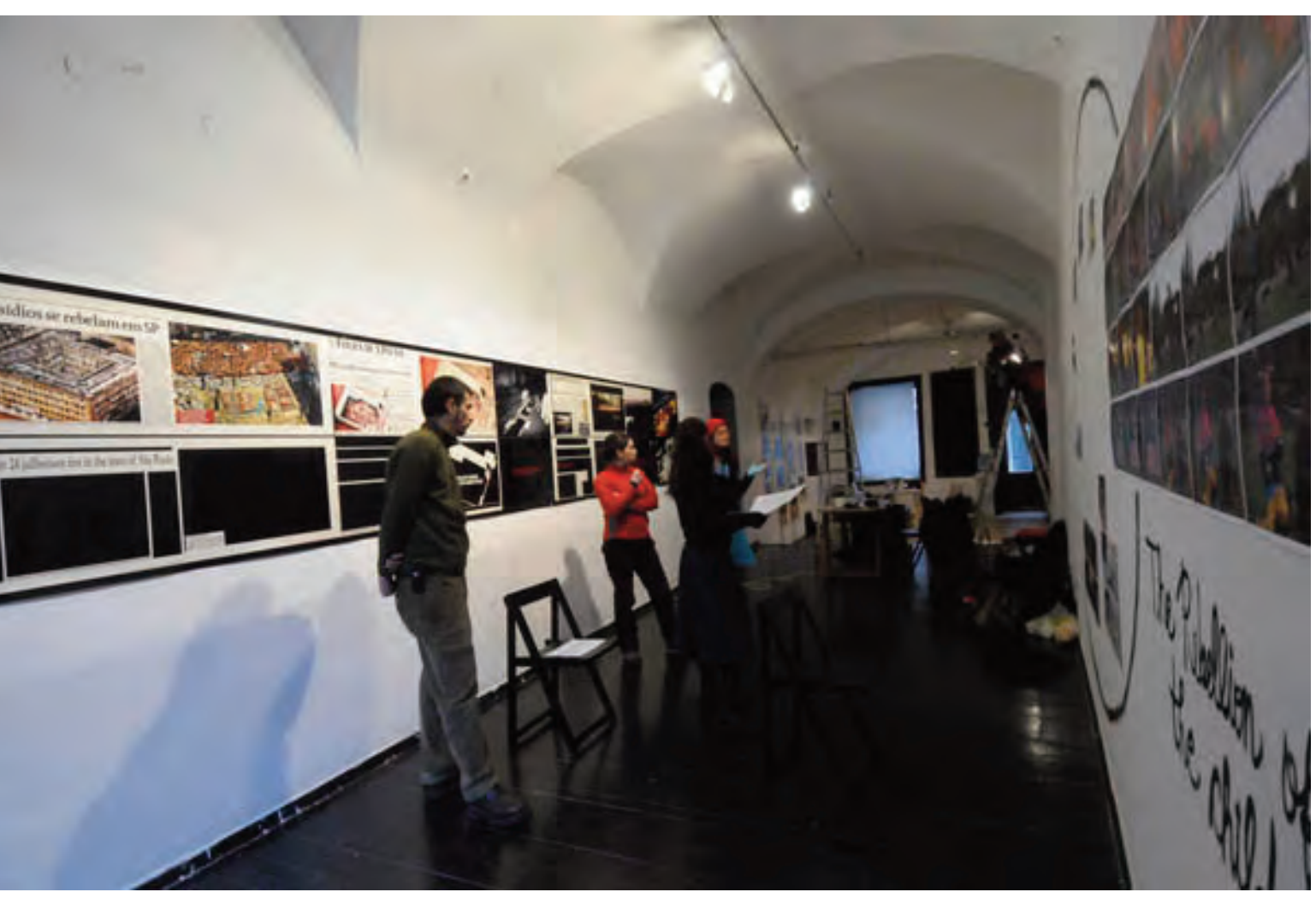

Instalação do Contrafilé na Skuc Galerija, Ljubljana, Eslovênia, 2008. 


\section{4 presídios se rebelam em SP}

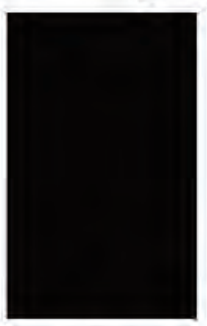

Temos medo de morrer, diz preso gabmiELA aTHLAS

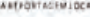

A Folha falou pelo celular com um preso da Penitenciária

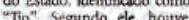
7io. Segundo ele, houve

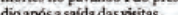
Folha - O Batalhio de Chogue ja Invadiu o pavilihto 2 ?

Tlo -16, mes as visitascontinuam aqui Se elas salisem, a gente tem
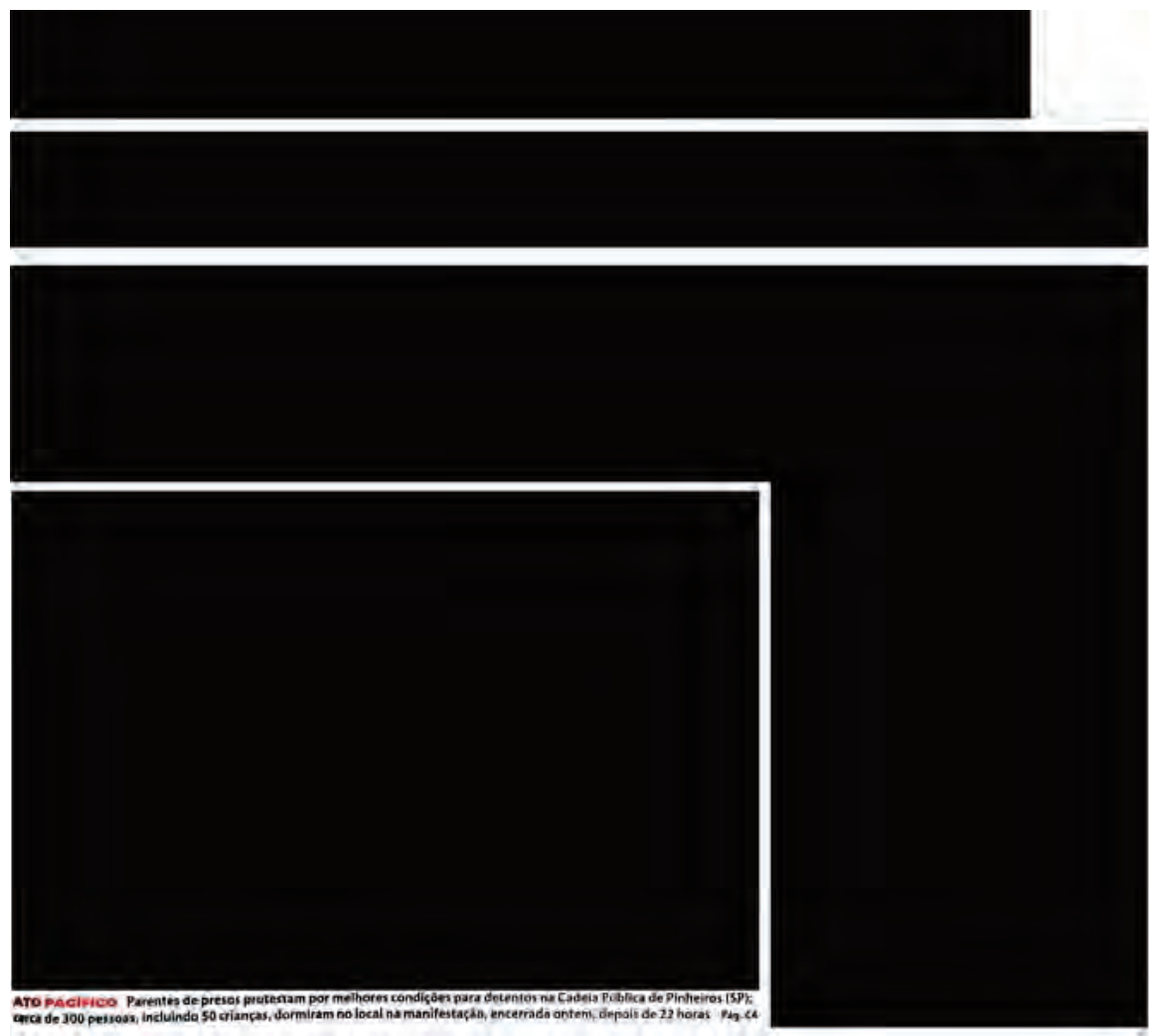


\section{Facção espalha faixas pela cidade}

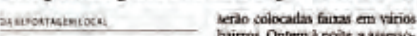

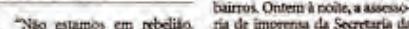

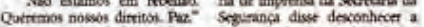

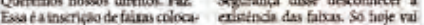
bos ontem em fuersos pontos da proninciar sobire c caso.

cidade por menteros do $\mathrm{POC}$ que

risetmilinerdale

Licers a tacyas ainda nlo be

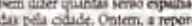

tagers vetriopa a enistencia de

fainas pas avenidas sumere, Re-

bespas $\mathrm{e}$ Consolacto lzodi so-

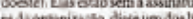

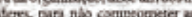

pesious gue estiverem projand

emcaso de a pollicin chogt

"Naswo objetive $f$ mostrar para

a populapio que qutrinios tage

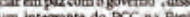

im intogrante do PCC na Finf-
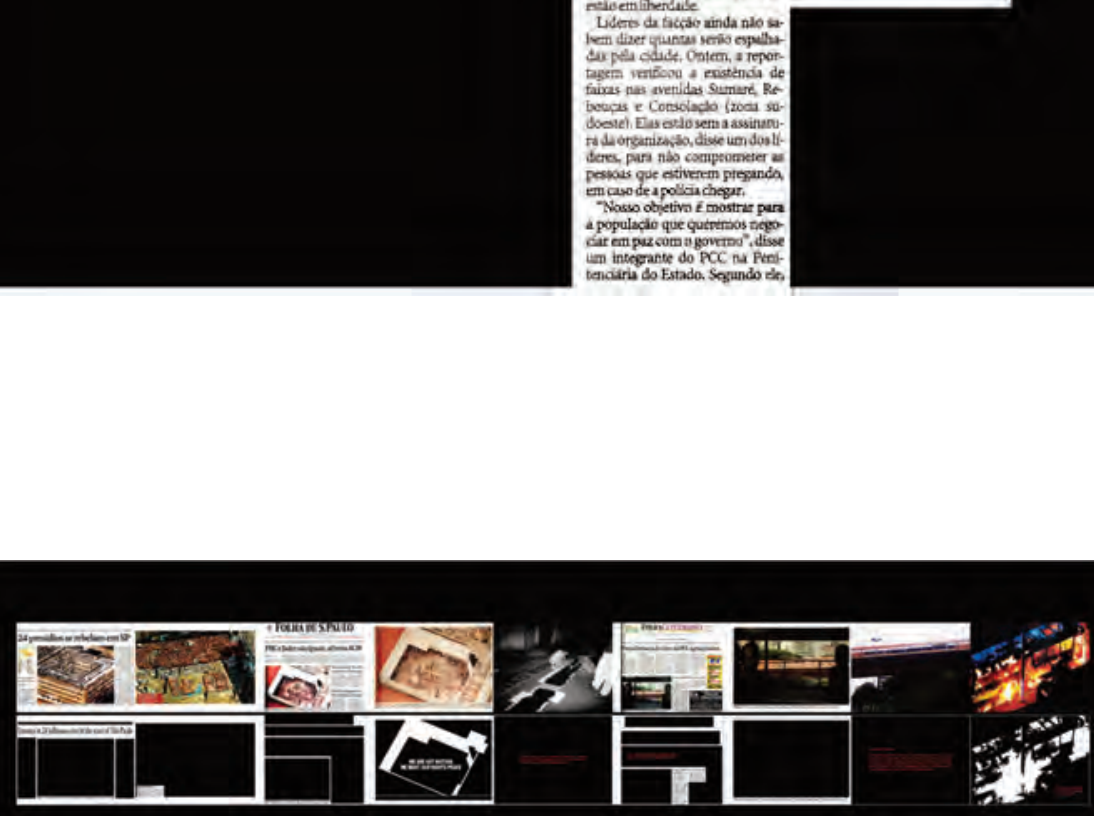

Imagem da sistematização feita pelo Contrafilé do trabalho do MICO utilizando a frase

"Não estamos em Rebelião". Trabalho apresentado na exposição "If You See Something,

Say Something", que aconteceu na Austrália em fevereiro de 2007. 
No plano micropolítico, o que houve foi um deslocamento de outra natureza. Sentíamos aquela situação como a própria "brecha" e intuitivamente sabíamos que ela somente poderia ter sido aberta através da representação direta, no engendramento de uma estratégia que operou marcando a irrupção da multiplicidade: nós nos rebelamos em prol da delicadeza disso que escapa, da escuta perdida para um lençol branco, para uma frase como "Não Estamos em Rebelião..." escrita por filhos e mulheres dos presos; e contra esse eterno massacre que impossibilita a conexão com o "fora" ${ }^{{ }^{11}}$, com aquilo que desconhecemos totalmente, reduzindo o não-saber a uma "ameaça".

Alguns anos mais tarde, em 2007, o coletivo Contrafilé, que nasceu como desdobramento do MICO, sendo composto por quatro de seus integrantes, fez uma releitura do processo vivido na época da rebelião e criou um trabalho que foi apresentado dentro do projeto de exposição e website "If You See Something, Say Something", que aconteceu na Austrália em fevereiro de $2007^{32}$.

31. Utilizarei aqui o "fora" no sentido atribuído ao termo por Deleuze e Guattari, como linhas de fuga e zonas de desterritorialização que obrigam a pensar: " [...] que relação com o estranho, que proximidade do caos suporta o território?

Qual é seu grau de fechamento ou, ao contrário, de permeabilidade (crivo) ao fora (linhas de fuga, pontas de desterritorialização)? Nem todos os territórios se equivalem, e sua relação com a desterritorialização, como vemos, não é de simples oposição" (François Bourabichvili, 2004, p. 24).

32. Com coordenação de Zanny Beg e Keg de Souza. Exposição individual na Chrissie Cotter Gallery e exposição coletiva na Mory Gallery, Sydney, Austrália, fevereiro de 2007. Segundo as curadoras: "If you see something, say something' is a discussion, exhibition and publishing project. Principally this will relove around an exhibition that will involve a small number of international and Australian artists whose work has explored aspects of dissensus". In: http://www.ifyouseesomethingsaysomething.net, acessado em março de 2012. 


\title{
Mídia Tática
}

A primeira ação do Contrafilé, que aconteceu no Festival Mídia Tática Brasil, realizado na Casa das Rosas em 2003, colocava em discussão as "novas tecnologias":

\begin{abstract}
Desdobramento do Festival holandês Next Five Minutes - atualmente em sua quarta edição - o Mídia Tática mostra trabalhos, performances, workshops, palestras, intervençōes de rua e eventos festivos que procuram, sobretudo, celebrar a diversidade cultural e a organização descentralizada da mídia e da comunicação. A idéia do festival é também promover novas potencialidades midiáticas tornadas possiveis graças ao crescente acesso aos equipamentos de mídia e à conseqüente explosão de produção "faça-você-mesmo" - cada um, a partir de variadas ferramentas, pode criar suas próprias formas de comunicação desvinculadas de interesses de mercado e de agendas ideológicas associadas aos grandes meios de comunicação. ${ }^{33}$
\end{abstract}

Um dos organizadores do evento, Felipe Fonseca, escreveu um texto sobre a experiência do Mídia Tática ressaltando a característica de troca entre pessoas que criam formas alternativas de mídia e comunicação: "Apesar de ser antes de tudo um projeto focado na educação midiática, ele proporcionou um ritmo de convivência entre as pessoas que levou a um grande nível de experimentação - técnica, social e administrativa." ${ }^{34}$

Esse festival inaugurou uma nova política federal em São Paulo baseada na discussão sobre tecnologia como forma de inserção cultural e política, sobre redes de conhecimento e difusão da própria 
produção, o que seria a base do projeto de democratização digital do Ministério da Cultura tendo à frente Gilberto Gil e Juca Ferreira (2003-2010).

Segundo Gilberto Gil, a importância do Mídia Tática Brasil se dá na medida que pretende discutir a utopia digital brasileira. 'Antes mundo era pequeno, porque Terra era grande/hoje mundo é muito grande, porque Terra épequena', citou o ministro, Parabólicamará, composição sua de 1996. E completou, 'A antena não é apenas parabólica, ela tem a ressonância de uma cabaça de berimbau, uma cabaça parabólica que poderia simbolizar a utopia digital brasileira. Seria mera utopia?' Gilberto Gil aproveitou para colocar o Ministério da Cultura como espaço privilegiado para esse tipo de debate. ${ }^{35}$

Podemos ver nesses depoimentos um posicionamento político que define a "mídia tática" como aquela que opera em uma dupla conexão - com o espaço presencial e o espaço virtual simultaneamente e que seria, em si, resultado de uma dupla captura. Nesta, cada espaço assegura ao outro os movimentos de desterritorialização e reterritorialização constantes, "dois devires se encadeando e revezando segundo uma circulação de intensidades que empurra a desterritorialização cada vez mais longe" (Deleuze e Guattari, 2004, p. 19).

Nesse contexto, o Contrafilé criou a obra "Corda: intervenção em mega escala", na qual uma corda foi instalada atravessando a Avenida Paulista do alto de um prédio até o subsolo da Casa das Rosas. Para realizá-la, o grupo teve que fazer um trabalho de convencimento dos moradores e do zelador do prédio e passar por uma operação arriscada, pois a corda foi amarrada na laje do edifício e 
trazida de rapel até a rua, arrastada atravessando a rua e depois erguida, formando uma linha material que cruzava a Avenida.

O trabalho tratava basicamente disso: a comunicação que burla regras e códigos pré-estabelecidos (aqui, vivida na negociação com moradores e zelador do prédio), tornando possível a criação de um "corte no espaço". Estou entendendo esse "corte" como a possibilidade de desdobramento de um espaço falsamente tomado como "dado". A ideia da intervençáo urbana como "corte" pode ser aproximada do conceito de corte-fluxo de Deleuze e Guattari, que afirmam que "O desejo faz escorrer, escoa e corta" (I976: II). Segundo François Bourabichvili, para os autores:

Cortar não é o oposto de escorrer (barrar), mas a condição sob a qual algo escorre; em outras palavras, um fluxo não escorre senão cortado. O que significa então 'cortar?? Precisamente o regime de escoamento de um fluxo, sua vazão, contínua ou segmentária, mais ou menos livre ou estrangulada (2004, p. 17).

O fato da "Corda" estar inserida no contexto do "Festival Mídia Tática”, atribuiu à experiência material de realização de um "corte no espaço" - à escala I:I (corpo:cidade) e sua representação (que simbolicamente apontava um devir no modo de lidar com o espaço) - o valor de novas tecnologias e de mídias táticas. Segundo o filósofo e semiólogo italiano Paolo Virno:

A primeira questão na ordem do dia é a das formas de luta. [...] Interdependência, conhecimentos compartilhados, capacidade de correlacionar-se e interagir: esses 'dotes profissionais' da multidão pós-fordista devem tornar-se temíveis instrumentos de pressão. 


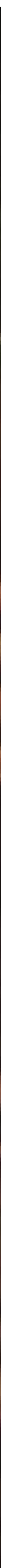

Imagens do trabalho "Corda" do Contrafilé, Festival Mídia Tática Brasil, São Paulo, 2003. 


\begin{abstract}
As plataformas reivindicadoras, em sintese, o 'que coisas queremos', dependem por inteiro do 'como podemos agir'para modificar as relaçôes de força no interior desta organização social deste tempo e espaço. Tudo depende, então, da invenção, sem preconceito, de novos 'piquetes' e novos 'cortejos internos', que estejam à altura da necessária flexibilidade e do modelo de acumulaçáo baseado no general intellect (Virno, 2005).
\end{abstract}

O fato de, nesse Festival, caber uma compreensão da mídia tática como "o corpo em confronto com a cidade" demonstra quão amplo pode ser o debate travado quando o que está em jogo são, como diz Virno, as formas de luta em sua potência e sua multiplicidade. Nessa plataforma, o Contrafilé optou por uma via "low tech" e o esquema metodológico utilizado para sistematizar o que descobriu a partir dessa ação é uma demonstração disso:

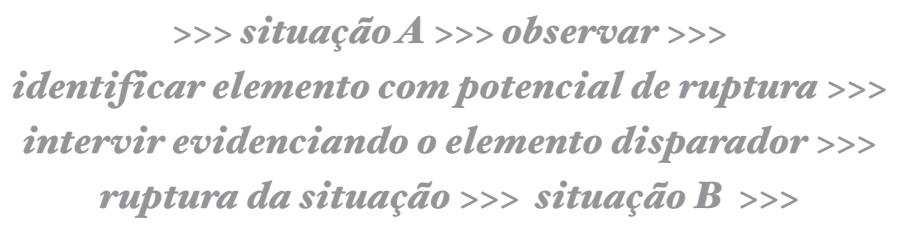

O próprio diagrama é uma ferramenta simples, feita de pensamento, lápis e papel. O que leva à pergunta de qual seria, então, a dimensão tecnológica da ação. $\mathrm{O}$ fato é que esse esquema aponta algumas linhas importantes de atuação do Contrafilé, que depois se desdobrariam em outras açôes do grupo e podem também colaborar para pontuar alguns aspectos que perpassam esse movimento cultural. A sistematização da experiência é uma dessas características. A ação nunca está deslocada da produção de pensamento e da produção, pelo 
próprio grupo propositor, de algum tipo de leitura sobre ela. Podemos entender essa como uma forma de "tomar para si a interpretação", escrever ao menos uma versão do que aconteceu ou do que está acontecendo. Essa pode ser considerada a atitude que circunscreve uma dimensão de luta nos trabalhos aqui apresentados: criar uma imagem própria e que possua a potência da circulação pública. A questão da imagem, por sua vez, não está sendo aqui pensada apenas como uma imagem visual, mas como imagem no sentido amplo, como um ter ritório de pensamento sobre determinado acontecimento.

Também é representado por esse diagrama o caráter intervencionista do tipo de trabalho aqui analisado, que não apenas "observa" uma determinada situação, mas para melhor compreendê-la, ativa algum elemento "com potencial de ruptura": um entendimento mais contundente do social parte assim do pressuposto de que é necessário colocar-se ativamente no centro de uma determinada problemática, desafiar a realidade a partir das sensaçôes que ela convoca no corpo para daí construir uma compreensão compartilhada sobre ela. A intervenção acontece, por sua vez, como uma evidência de caráter simbólico, pela ativação de um "elemento" que, por condensar uma sensibilidade coletiva, causa uma ruptura da situação estabelecida. A ruptura é aqui entendida como um resultado da precisão nessa operação de produção. O que se produz é, em última instância, a evidência de que existe um corpo coletivo compartilhando uma nova sensibilidade, que se anuncia. A "situação A e B" aparecem não à toa, mas como lugares referenciais do anúncio: em situação.

Aqui evoco, para delinear melhor o tipo de "subjetividade política" que surge nesse movimento cultural (o que aos poucos essa narrativa que parte de alguns trabalhos pretende ir situando na medida de sua construção), as palavras de Judith Butler no ensaio "Que 
es la critica? Un ensayo sobre la virtud de Foucault", presente na Revista Brumaria 7 (2006). Nesse ensaio, a autora cita a contribuição de Foucault para a construção de uma crítica como uma prática que questiona os limites dos modos seguros de conhecimento. O que levaria, segundo Foucault, a um impasse na teoria crítica e pós-crítica do nosso tempo que faz com que precisemos ir ao limite, mas não para ter uma experiência emocionante:

[...] o porque el limite sea peligroso o sexy, o porque eso nos lleve a una excitante proximidad al mal. Una se interroga sobre los limites de los modos de saber porque ya se a tropezado con una crisis en el interior del campo epistemológico que habita. Las categorias mediante las cuales se ordena la vida social producen una cierta incoherencia o ambitos enteros en los que no se puede hablar. Es desde esta condición y através de una rasgadura en el tejido de nuestra red epistemológica que la práctica de la crítica surge, con la conciencia de que y a ningún discurso es adecuado o de que nuestros discursos reinantes han producido un impasse. [...] Para Foucault, la crítica "es instrumento, medio de un porvenir o una verdad que ella misma no sabrá y no será, es una mirada sobre un dominio que se quiere fiscalizar y cuya ley no es capaz de establecer (id. ibid., p. 19) ${ }^{36}$.

Voltando ao diagrama esquemático do grupo Contrafilé, podemos ver ali a representação de uma espécie de "centralização" da margem (identifícar elemento com potencial de ruptura $>>>$ intervir evidenciando o elemento disparador), ou seja, o ato de colocar-se no centro da situação de exceção (ou de "ruptura") como uma tática para entender um campo de forças a partir de sua espacialização.

A criação do diagrama demonstra, assim, a tentativa de pro-

36. A autora cita, em nota: Michel Foucault, Qué es la crítica?. In: Sobre la llustración, Madrid, Tecnos, 2006, pp. 3-52. “Este ensayo consistió originalmente en una conferencia pronunciada en la Société Française de Philosophie el 27 de mayo de 1978, posteriormente publicada en el Bulletin de la Société française de Philosophie, año $84^{\circ}$, núm. 2, abril-junio de 1990, pp. 35-63." 
duzir uma imagem de como se dá essa disputa em determinado contexto, como uma anotação de campos de disputa e táticas flutuantes. A cartografia aparece, então, como uma das formas de registrar quando o corpo se coloca no centro de uma situação não como identidade, mas como subjetividade atravessada pelo mundo, com isso evidenciando tanto a constituição de si, quanto do espaço como uma realidade cambiante e interligada. Não há um centro único, mas a situação da "margem" que centraliza-se nos momentos de intervenção, como uma forma de tornar clara a dimensão do impasse na construção do social. Segundo o GAC:

A informação nos parece de grande utilidade quando integra uma ação sobre corpos que transitam num espaço de disputa, ou quando permite conbecer previamente este espaço com maior precisão, mas sabendo que o espaço se transforma com a ação, de modo que a ação não será sempre coincidente com os objetivos prévios. É essa forma de conbecer, em parte consciente e em parte não, em parte objetiva e em parte subjetiva (...) que nomeamos 'escalla I a I', por oposição à definição 1:100o, 1:1000.00o ou I a n dos mapas geográficcos, escolares, demográfícos ou militares. É a escala na qual vivemos a ação e nos movemos, nos detemos, confrontamos, avançamos ou retrocedemos, é a negação da representação de outra coisa, pois é a realidade vivida como imediata e de maneira compartilhada. $O$ 'I a I', então, aparece como uma reiteração do uno e único, ou como uma possibilidade de relação entre dois corpos diferentes (GAC, 2004). 
PROJETO JO 08:Layout $1 \quad 7 / 25 / 12$ 11:44 AM Page 100
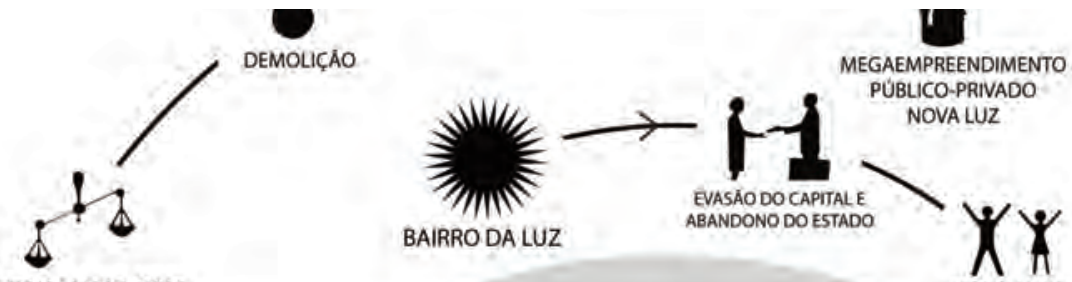

SISTEMASLLEGISLATIVO E JUDICIAL CONIVENTES rapida desopropriação X
lenta opeloçao

DESAPROPRIACCOES sem justo e prévio indenizoçoó em restituiçoo de fundo de comérùi

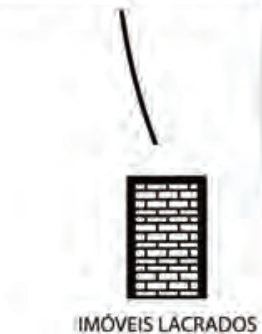

IMOVEISLACRADOS

\section{Mundo Brasil}

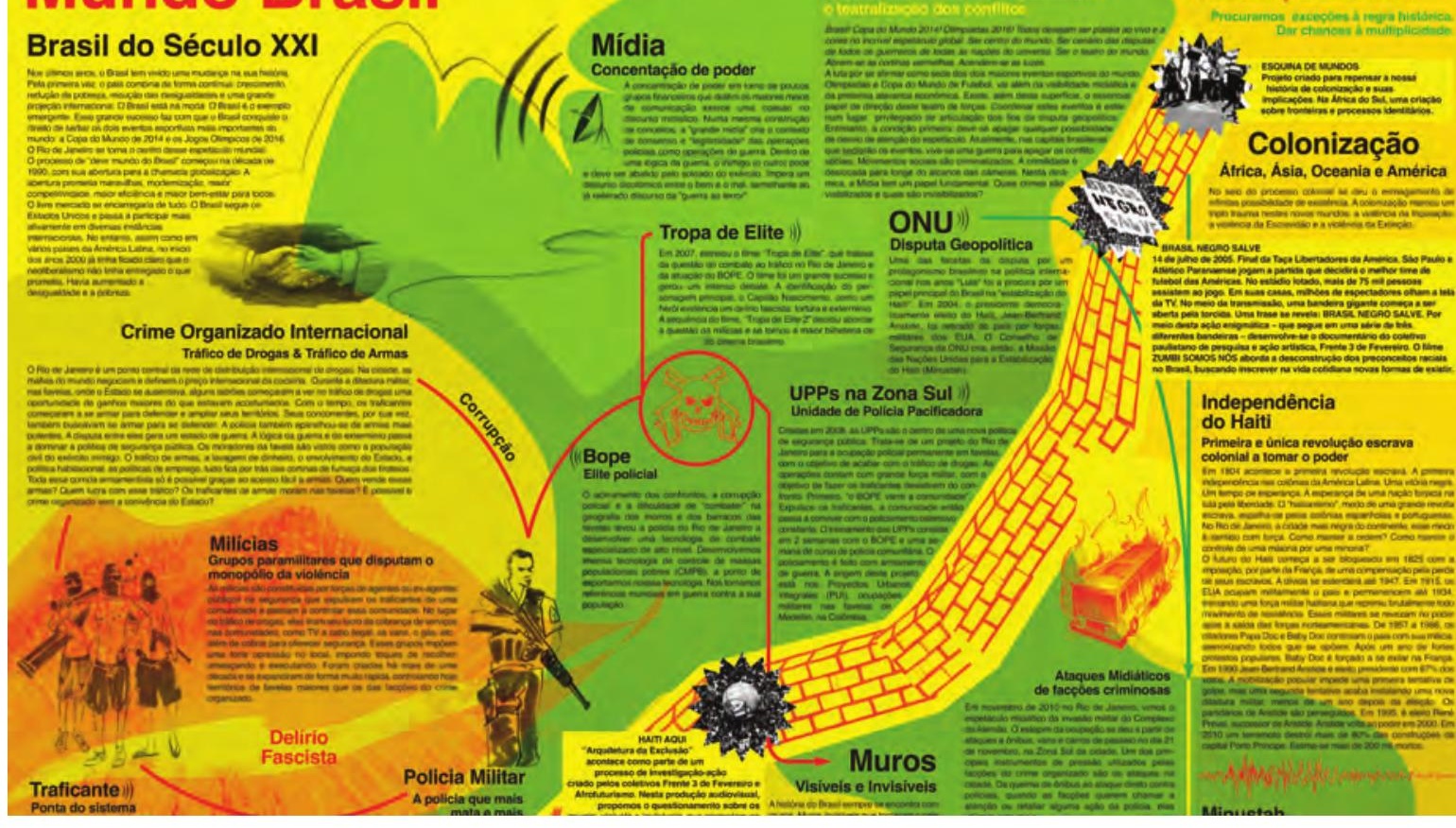

Como inventamos nosso passado?

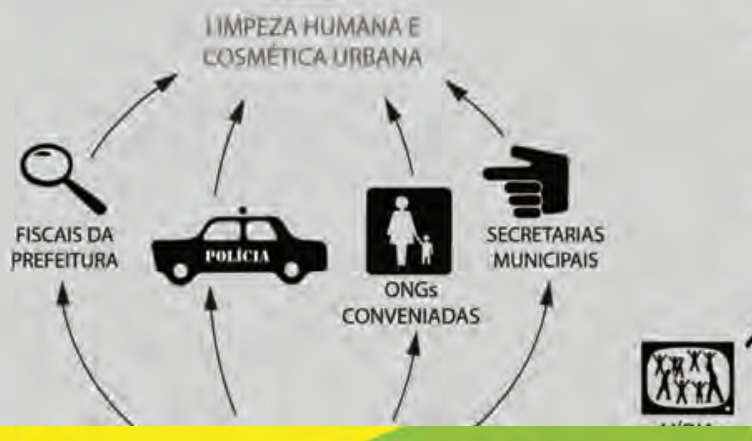

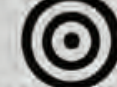

PODER PUBLICO revitalisacio

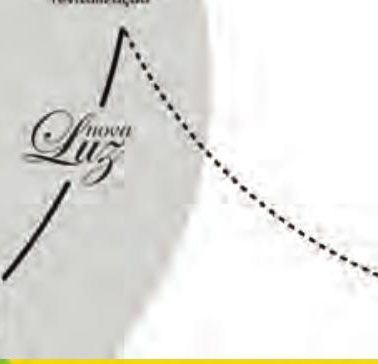




\section{Enunciação e Emancipação}

Este tipo de representación gratuita, desarrollada sobre el territorio de la ciudad donde se produce el acontecimiento antagonista, genera un desplazamiento hacia un tipo de lógica política nueva. Es la lógica del agenciamento, una lógica que emplea la representación por su efectividad material, ayudando a los grupos a articularse a sí mismos de una forma abierta y horizontal. En otras palabras, es una lógica constructiva de expresión múltiple (Brian Holmes).

Se a sistematização dos processos é uma das formas importantes de produção de "imagens" nos trabalhos aqui apresentados, é porque a "obra" é compreendida, em si, como a capacidade de tornar visíveis os agenciamentos ${ }^{37}$ que produzem e inscrevem "um olhar singular diante do mundo".

O que se torna visível é um acontecimento no qual as estratégias micropolíticas de disputa física e simbólica do espaço social são materializadas, traçando um território novo e frágil. Segundo o sociólogo e filósofo italiano Maurizio Lazzarato:

El acontecimiento muestra lo que una época tiene de intolerable, pero también hace emerger nuevas posibilidades de vida. Esa nueva distribuición de los posibles y de los deseos abre a su vez un proceso de experimentación y de creación (2006, p. 44).

37. De acordo com Deleuze e Guattari: "Segundo um primeiro eixo, horizontal, um agenciamento comporta dois segmentos, um de conteúdo, outro de expressão. De um lado ele é agenciamento maquínico de corpos, de ações e de paixões, mistura de corpos reagindo uns sobre os outros; de outro, agenciamento coletivo de enunciação, de atos e de enunciados, transformações incorpóreas atribuindo-se aos corpos. Mas, segundo um eixo vertical orientado, o agenciamento tem ao mesmo tempo lados territoriais ou reterritorializados, que o estabilizam, e pontas de desterritorialização que o impelem" (Deleuze e Guattari, 1977 apud Zourabichvili, 2004, p. 8). 
A construção de imagens e narrativas críticas que transfor mam um processo propriamente em um acontecimento ocorre quando nessas se realiza uma sintese disjuntiva, ou melhor, não apenas se evidencia o "antes" e o "depois" do acontecimento, mas o instante de constituição de uma diferença que faz sentido (François Bourabichvili, 2004, p. 6).

A dificuldade na sistematização de processos para a criação desse tipo de imagem está justamente em encontrar formas de enunciação que consigam captar a fragilidade que compóe a produção dessa diferença. No entanto, captá-la é parte fundamental para a constituição da resistência política aqui relatada, que procura romper com o menosprezo pela fragilidade, que necessariamente decorre das experiências de vulnerabilidade ao outro e das turbulências desterritorializadoras (Rolnik, 2006, p. 5).

\section{[...] esta fragilidade nos é essencial pois indica a crise de um certo} diagrama sensivel, de seus modos de expressão e suas cartografias de sentido. Ao menosprezar a fragilidade, esta deixa de convocar o desejo de criação; ao contrário, ela passa a provocar um sentimento de bumilhação e vergonha, cuja conseqüência é o bloqueio do processo vital. Em outras palavras, a ideia ocidental de paraíso prometido corresponde a uma recusa da vida em sua natureza imanente de impulso de criação e diferenciação contínuas (Rolnik, 2006, p.7).

Para a criação dessas imagens da diferença nas quais a fragilidade aparece, um dos elementos de linguagem que foi se construindo nas práticas urbanas aqui apresentadas, poderia ser designado como o ato de prontidão para corresponder a uma tradução sensivel 


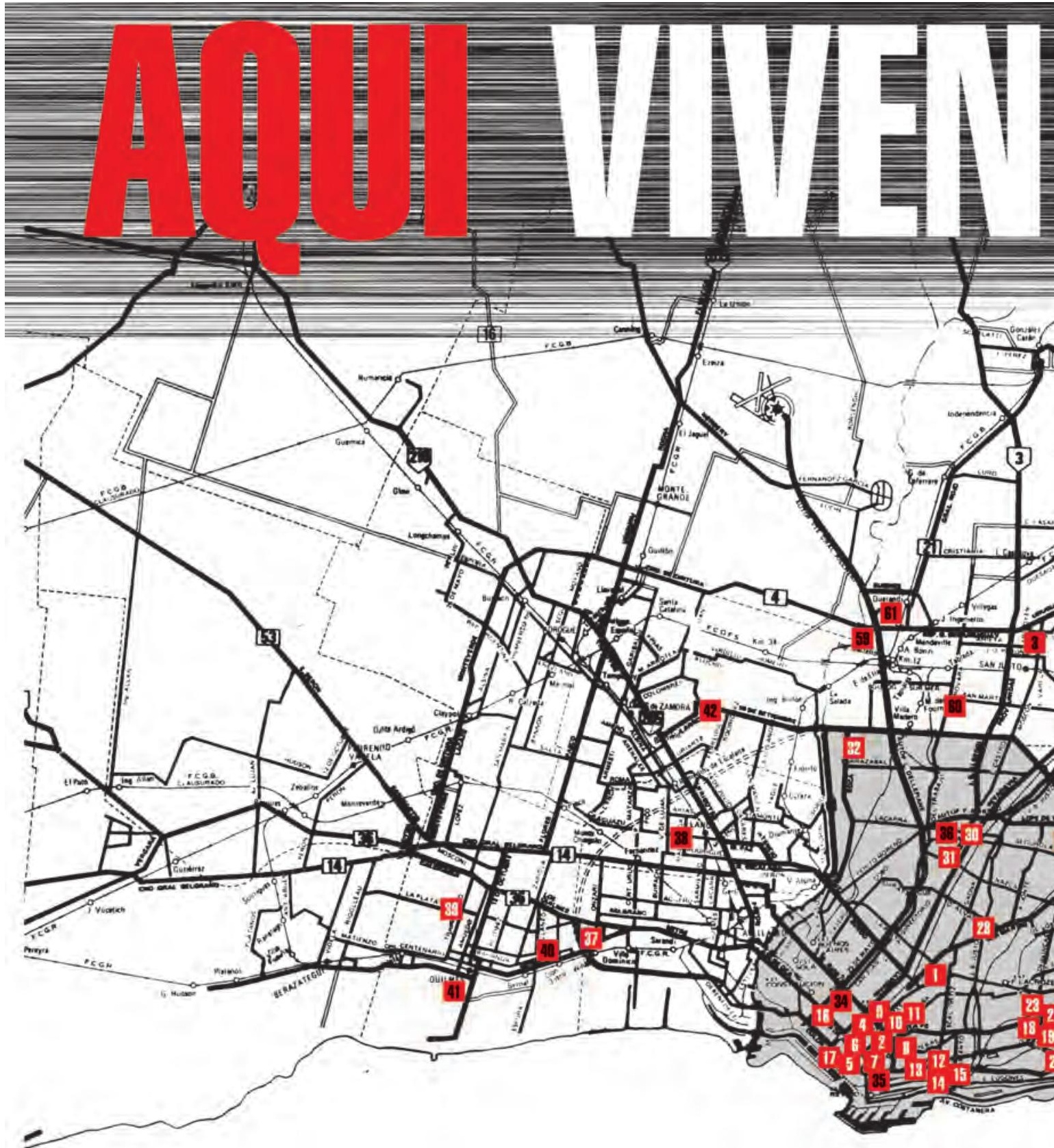

EENOCIDAS

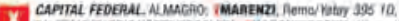

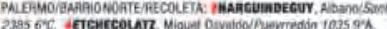

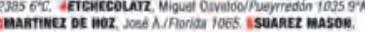

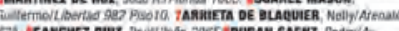

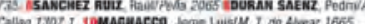

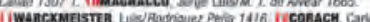

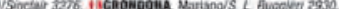

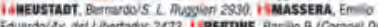

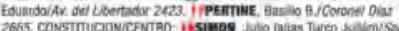

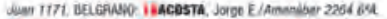

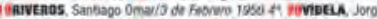

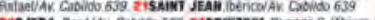

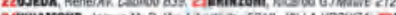

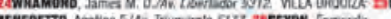

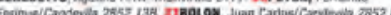

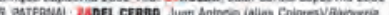

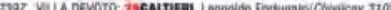

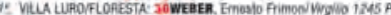

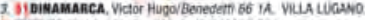

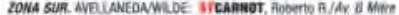

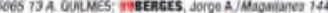

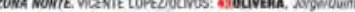

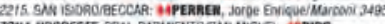
Heved

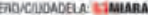

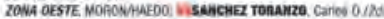
minadima 1555 !

A partir de escraches já realizados à casas de torturadores, o GAC cria na cartografia Aquí Viven Genocidas ${ }^{39}$ uma forma de tornar visível o processo de produção de um espaço diferencial na cidade de Buenos Aires. Nessa ação, interpreta o escrache como enunciado, inscrevendo outro enunciado na cidade, que será interpretado e acionado em outros níveis, produzindo outros enunciados de acordo com os diferentes contextos nos quais for colocado, e assim por diante. 


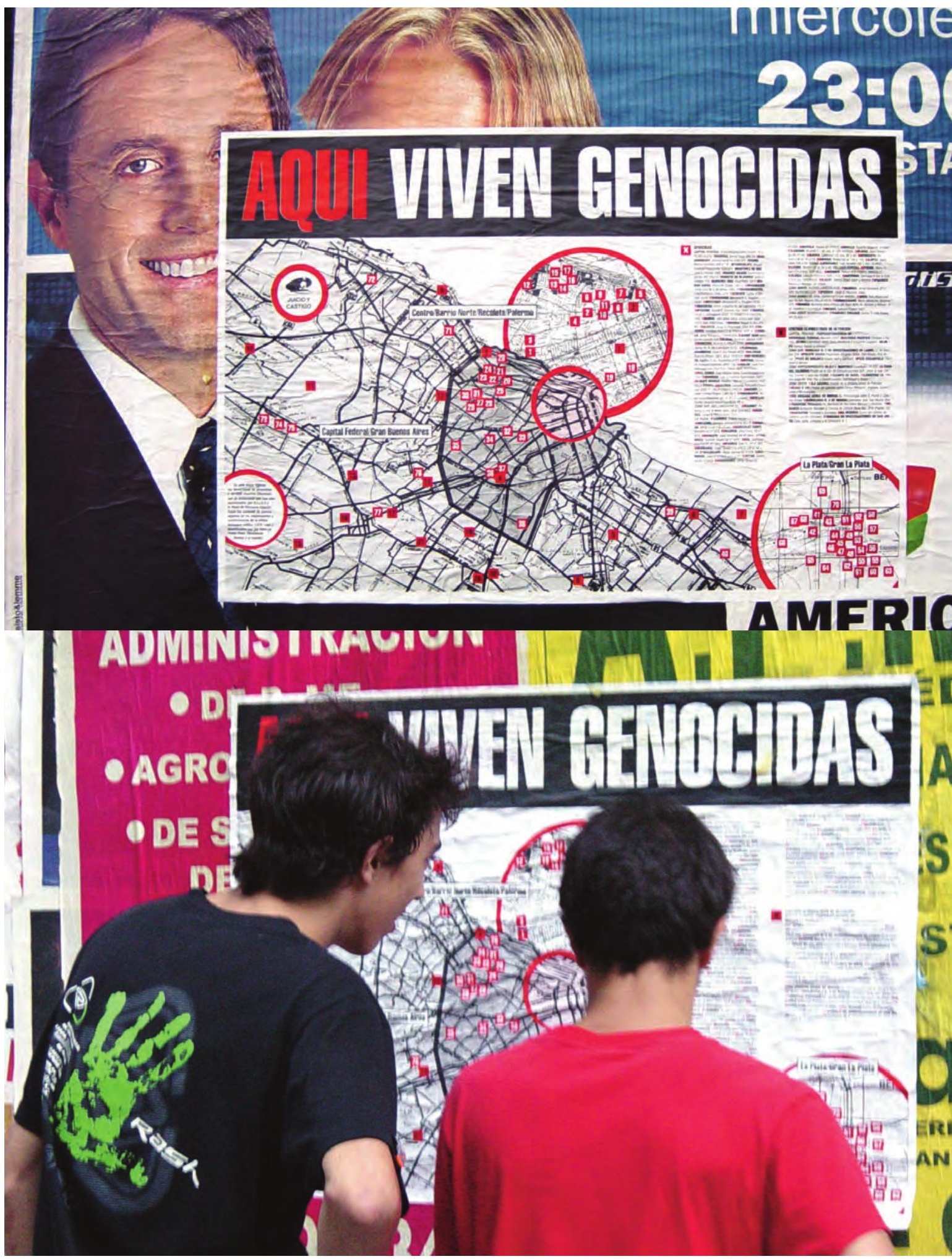


dos enunciados $4^{40}$, desdobrados como intervençōes ${ }^{4 \mathrm{I}}$ - o Colectivo Situaciones fala em uma prática de expressão autônoma (2009, p. 13). Portanto, o acontecimento se dá quando um enunciado adquire propriamente caráter de enunciação, para isso sendo necessário um processo de confrontação simbólica. Um exemplo disso é o trabalho "A Rebelião das Crianças", do Contrafilé. A partir da imagem construída pela grande mídia e pelo Estado dos meninos da FEBEM como "marginais", "internos", "bandidos" e de suas mães como "agentes externos incitadores de rebeliōes", o grupo quis entender do que, afinal, se tratava aquilo, desencadeando todo um processo de tradução e contra-tradução.

A "Rebelião das Crianças" é uma das situações metafóricas ${ }^{43}$ criadas pelo Contrafilé. Com o intuito de gerar "conhecimento situado" ${ }^{42}$ que resulte em enunciaçôes coletivas construídas a partir da fragilidade, o grupo propõe conversas com comunidades e grupos, chegando a novas imagens, sensações e possibilidades de intervenção.

Situação Metafórica sf 1 Situação que cria pontes entre diferentes mundos e permite associar o que está sendo dito/vivido a algo já vivido por todos, estabelecendo assim alguma ligação com o conhecimento cultural comum. Cria então um parâmetro para o diálogo, um ponto de convergência entre as pessoas que compõem um grupo; cria um 'chão comum'; 2 Mais que 'metáforas', devem conter, necessariamente, o desenvolvimento real de uma ação; 3 Contexto extraordinário, inesperado, que provoca ruptura no processo cognitivo de seus co-criadores. Situação que rompe a rede de relações estabelecida e dá passagem a uma nova trama de relações. A ruptura aqui é um projeto de reconstrução coletiva das representações. O novo sentido aparece para os co-criadores como um estímulo mobilizador de seu potencial inventivo. Eles necessariamente criam para assimilar a experiência, são ativos em sua realização. O momento da ruptura corresponde à inauguração do acontecimento; 4 Um sonho real. 
JUVENTUDE ENCARCERADA Ele disse que o governo abriu sindicância e informará o caso à Organização dos Estados Americanos

\section{Lembo culpa 'agentes externos' por motim}

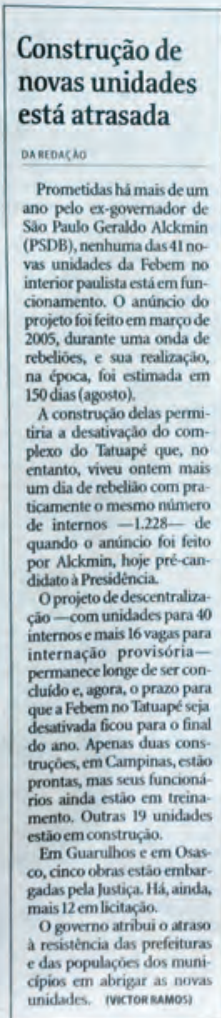

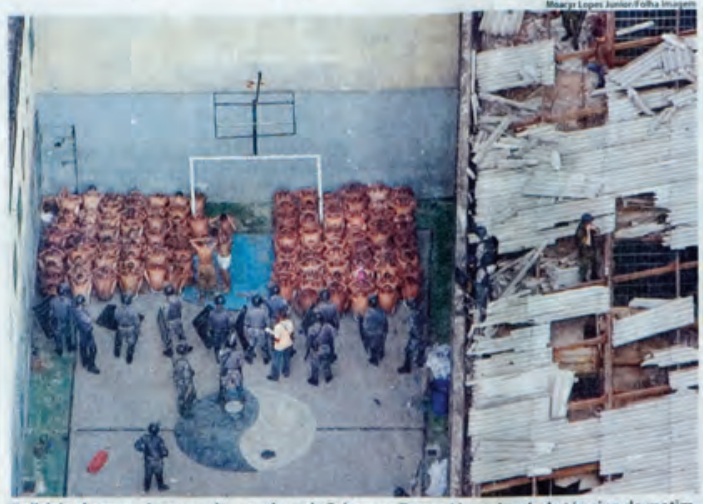

Policiais observam internos do complexo da Febem no Tatuapé logo depois do término do motim

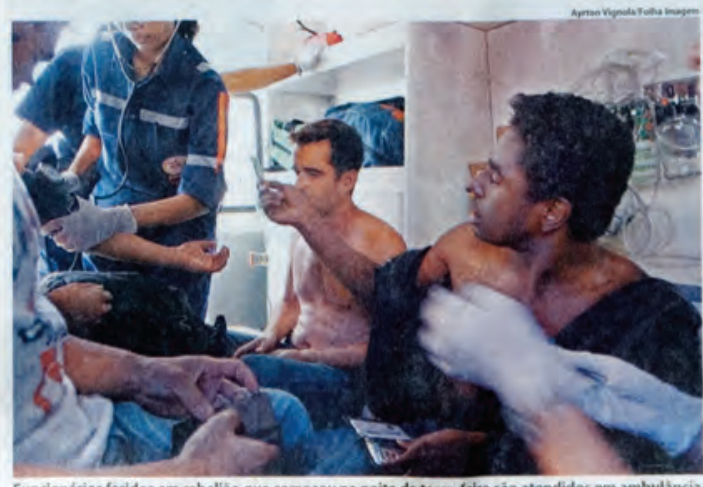

Funcionários feridos em rebeliáo que começou na noite de terça feira sáo atendidos em ambuläncia
MAURICIO SIMIONATO

o governador de Sán Paulo, Claudio Lembo (PFL), disse ontem em Jundiai $(60 \mathrm{~km}$ de $\mathrm{Sa}$ Pialo) que as rebelives nas unida. por agentes externos" que falam

"Nós temos aqui e ali sabe o que? Provocaça de agenteserter nos. É bom que fique daro. Toda vez que alguns agentes catemo? vez que alguns agenies cotemos
ingressam na febert com uma idera de que sso humanos, na verdade eles estáo criando atnos deve manos", disse nado sobre a rebe. liầo na Fethem no Tatuape Lembodisse que - governo abriu sindicancia para apurar os nomes dos "agentes expois disso, informará o caso OEA corganiza. Americanos). Ele ainda disse que "nào é justo que alguém que humanes viole dh. reitoshumanos". Ogovernader participou onte em lundiai da inauguracaio ofe obras no aeroporto de Jundiai, $n$. rodovia Anhanguera e do rectaorante Bom Prato.

Ele também voliou a afirma que a Febem no Tarbape seri
sativada até o fim deste ano.

O govermador mencionou qua. tro preficituras administradas pe. lo PT - Suzano, Osasco, Guar. o programa do governo de des. o programa do governo dé dos. que nào tèm permitido a Feberm sio cidades de um partido que bloqueia que a socaedade poss As prefeituras dessas cidades As prefaturas descos cidades sentou projetos das unidado sentou projetos das unidiacos Prefitura de Sio Carlos infor. mou que nunca houve proieto de instalacio da Febem na ódade. Quectionado sobre uma cidade administrada pelo PSDB que também rejeitou a Fetem - Bra. ganca Paulista-, Lembro afir mou que nozocia com a adminis.

Tanentavelmente, as didade
OEA

o Ceril (Centro pela Justica eo Direito Internacional) vai pedir a representantes da mericana de D. mencana de Drde Oft pumanicie da OEA que visite bemno Taruapt. Segundo Beatrit Aflonso, do Cerit. o convite sera di. ripido à relatoria de pessoas priva dasde liberdide. Em novembro de 2005 , foi encauma acusacto de maus tratos e cepancamento de internos do Tatuape No més se guinte, o órgio determinou que c governo adotase metidas pura proteger os adolicscentes. Em feverciro deste ano, entida. des brasileiras de dircitos huma. nos enviaram relatóno a Corte que apontava imogulandades no na Feberm no Tatuape: Segundo relatorio, a fundacáo niw cun priudeterminaples do óngia.

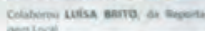
minhada a Corte

“Agentes externos": denominação do governo estadual para as mães organizadas dos jovens encarcerados.

40. Enunciados que podem ser de vários tipos: a voz da grande mídia, a voz de pessoas comuns, a voz de pessoas convidadas para pensar juntas a partir de uma determinada "situação", a ação de um movimento social, as próprias obras-interventivas dos coletivos. 41. Que podem também se dar em vários espaços: na cidade, no corpo, no meio editorial, etc. 42. Segundo a antropóloga Florencia Ferrari, “A expressão 'conhecimento situado' foi cunhada por Donna Haraway no contexto do debate feminista nos anos $\mathbf{8 0}$ para definir um saber corporificado, isto é, um saber no qual o significado se cria através dos corpos. A autora reivindica uma 'objetividade feminista', uma 'posição limitada', parcial (1988: 588, 592). Entendo que o conceito indica uma relação de transformação mútua entre pesquisador e pesquisados, que não podem ser apreendidos em posições fixas, como 'identidades"' (Florencia Ferrari, 2010, p. 15).

43. "Programa para Descatralização da Própria Vida", "A Rebelião das Crianças",

"Estado de Confinamento", são algumas das situações metafóricas inventadas pelo grupo. Todas são apresentadas ao longo desta dissertação. 


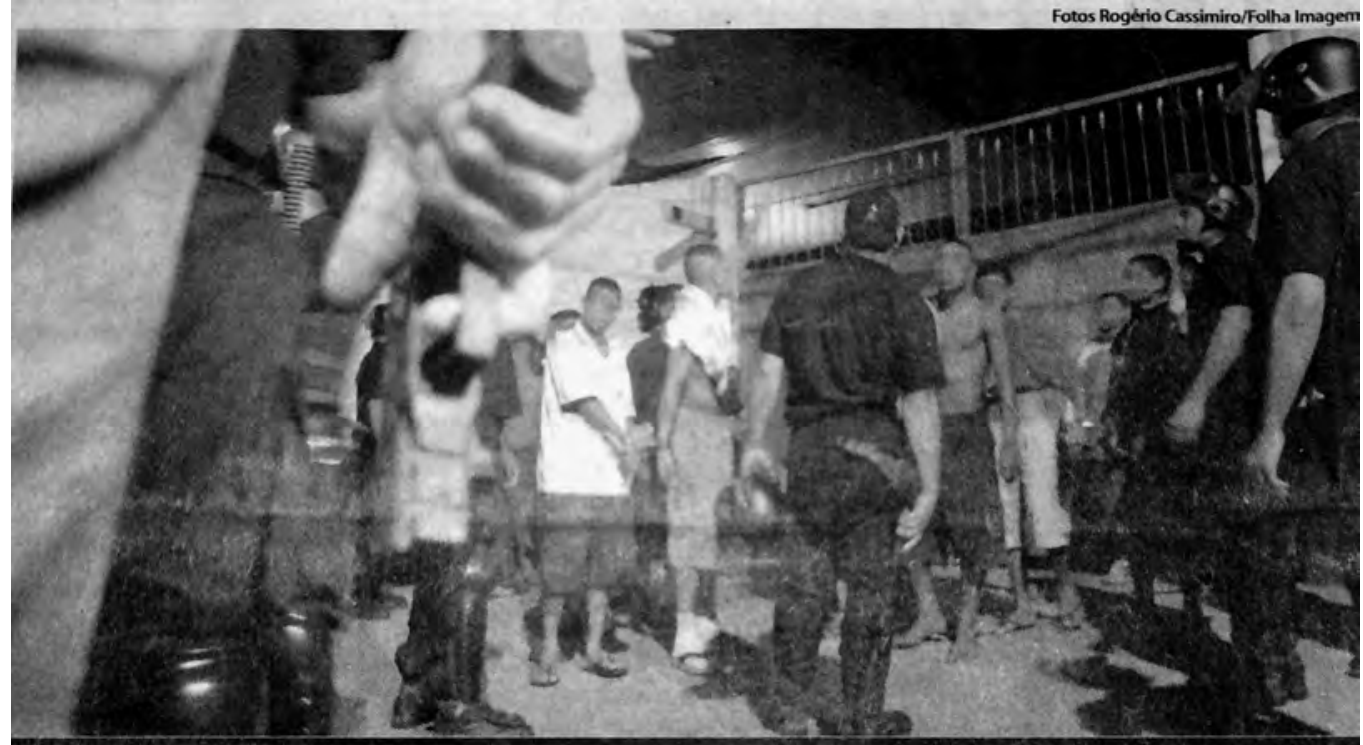

Policiais e internos do complexo da Febem no Tatuapé, após a rebeliāo, na madrugada de ontem

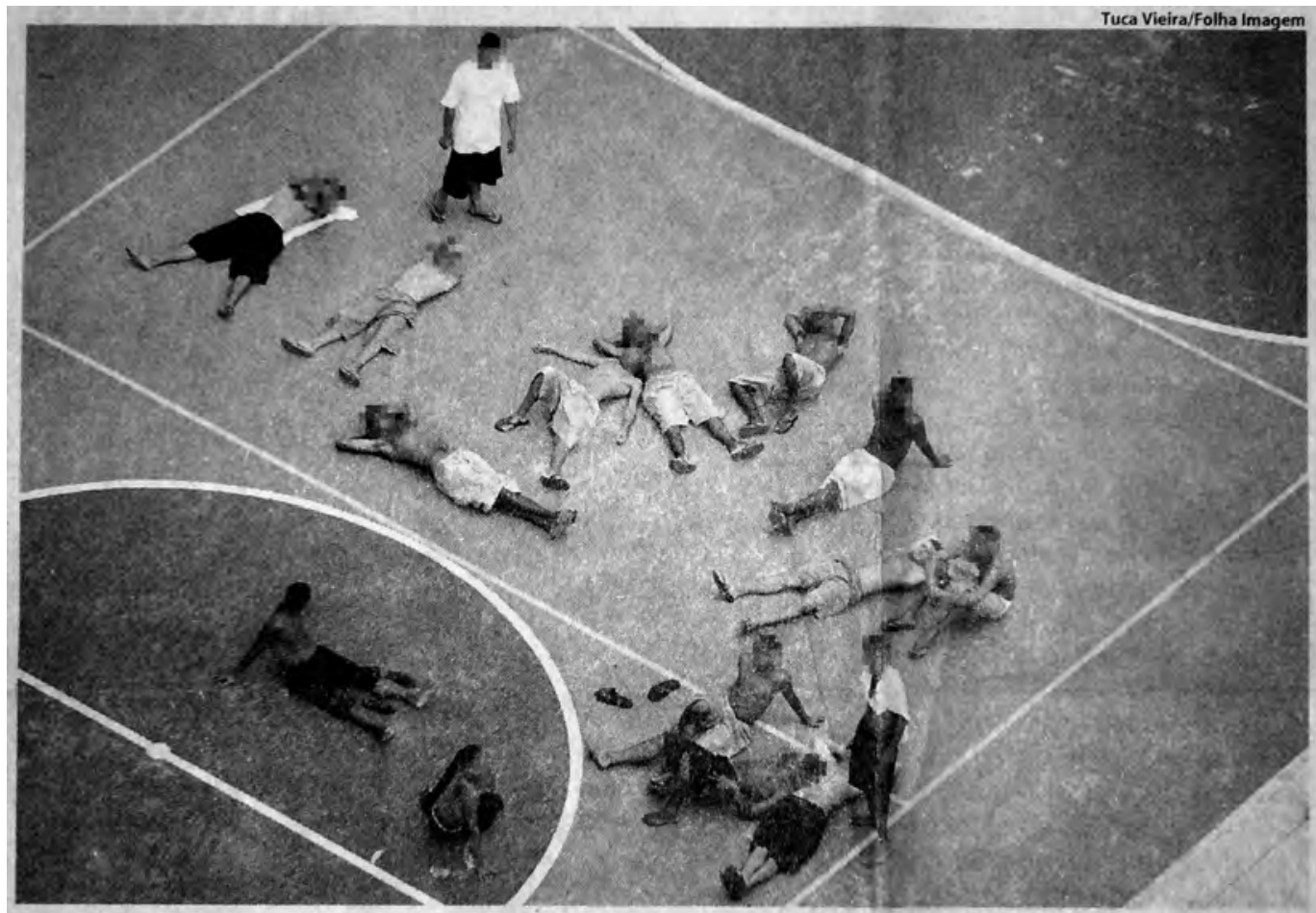

Internos rebelados ocupam pátio de uma das unidades da Febem no complexo da Raposo Tavares 


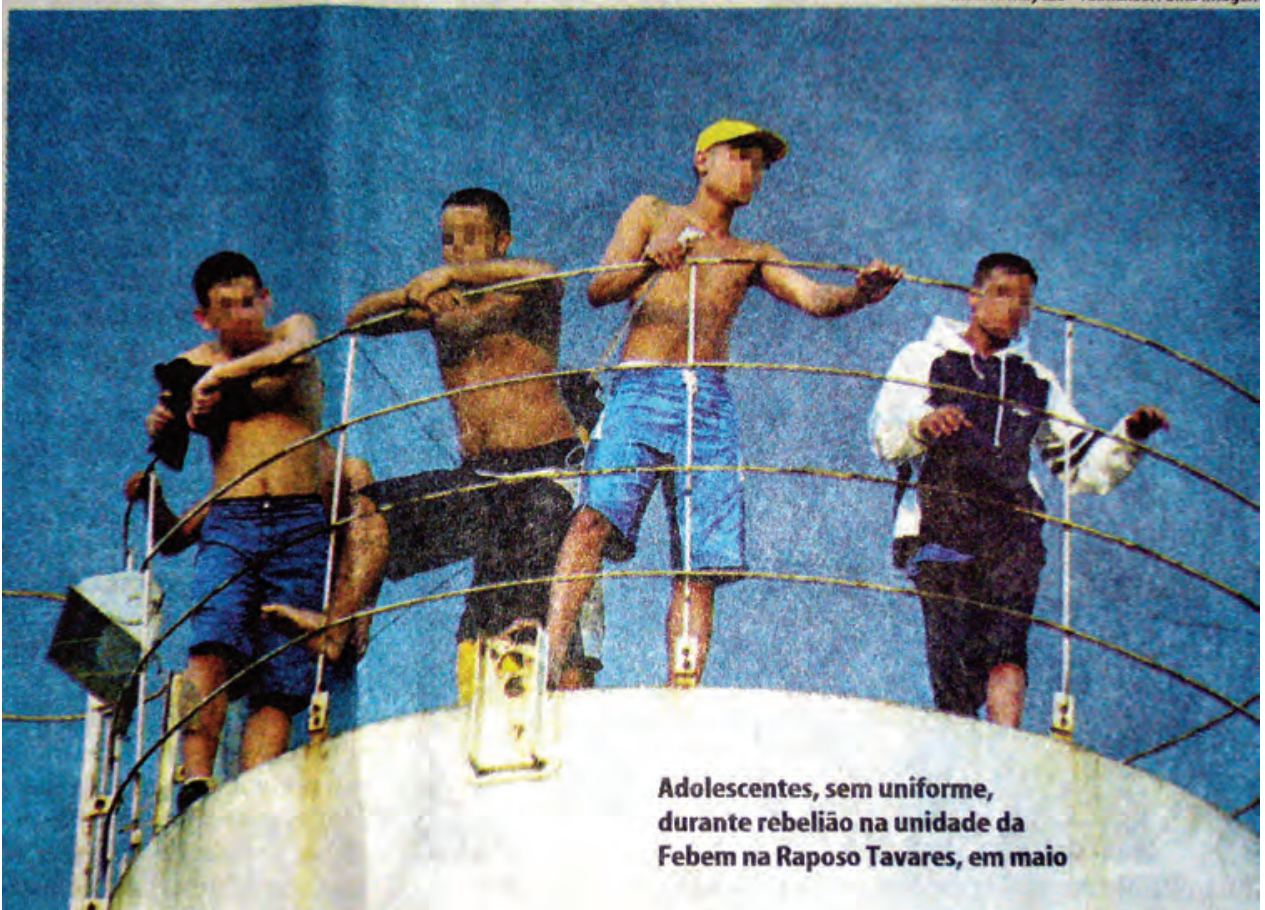

\section{Febem éalvo de protesto em São Paulo}

\section{Manifestantes cobraram explicação para mortes de internos e reclamaram de maus-tratos}

\section{AFRA BALAZINA}

\section{DAREPORTAGEMLOCAL}

Entidades de direitos humanos, ex-internos e familiares de internos protestaram ontem em frente à Secretaria de Estado da Justiça, no centro de Săo Paulo, contra a Febem (Fundação Estadual do Bem-Estar do Menor).

Segundo os manifestantes, foram registradas 27 mortes de jovens internos da Febern nos últimos três anos em condiçóes rî̉ esclarecidas, Eles dizem suspei tar que foram em decorrência de maus-tratos e acusam a entidad de nâo garantir a integridade fí- sica dos internos. Durante o ato, do qual participaram 23 entidades, foi pedido o afastamento da presidente da fundaçăo, Berenice Maria Gianella.

"No dia 26 Ipróxima quartafeira), a fundacào completa 30 anos. E estamos cansados de ver maus-tratos contra os jovens", disse Ariel de Castro Alves, da coordenaçào do Movimento Nacional de Direitos Humanos.

A assessoria de impiensa da Febcm disse ontem que as mortes atâo sendo investigadas pela Policia Civil e pela Corregedoria da instituiçăo. A apuraçâo ainda nẫo foi concluída. $\mathrm{A}$ fundaçào não comentou o pedido de afastamento da sua presidente.

Solange de Moura Queiroz, que teve um filho interno no $\mathrm{Ta}$ tuapé morto em 2004, esteve na manifestaçào, "Após denunciar os funcionários que o espancaram na Vila Maria, meu filho apareceu queimando no Tatuapé, como uma tocha humana", contou. Segundo ela, ogaroto foi socorrido por outros internos. "Lutou 17 dias no hospital, estava com $70 \%$ do corpo queimado e morreu. Dizem que foi suiddio, mas seique nào éverdade. O grupo fez um minuto de silêncio ao meio-dia gem aos internos mortos, e 27 balōes pretos foram soltos em sinal de luto. Em frente ao prédio da secretaria, foram colocados bonecos para representar internos que teriam sido torturados nas unidades. Até o monumento Glóna Imortal aos Fundadores de Sco Pawo, en frente ao Páteo do Colegjo, foi parcialmente coherto porcartazes.

- Bssa gestáo e a mais autoriti ria que enfrentamos. Não há diàlogo com as entidades e não podemos entrar nas unidades para verificar as denúncias, Berenice quer implantar o sistema penal juvenil na Febem", diz Alves.

Seqüências de jornais sobre as rebeliões na FEBEM com anotações feitas pelo Contrafilé. 


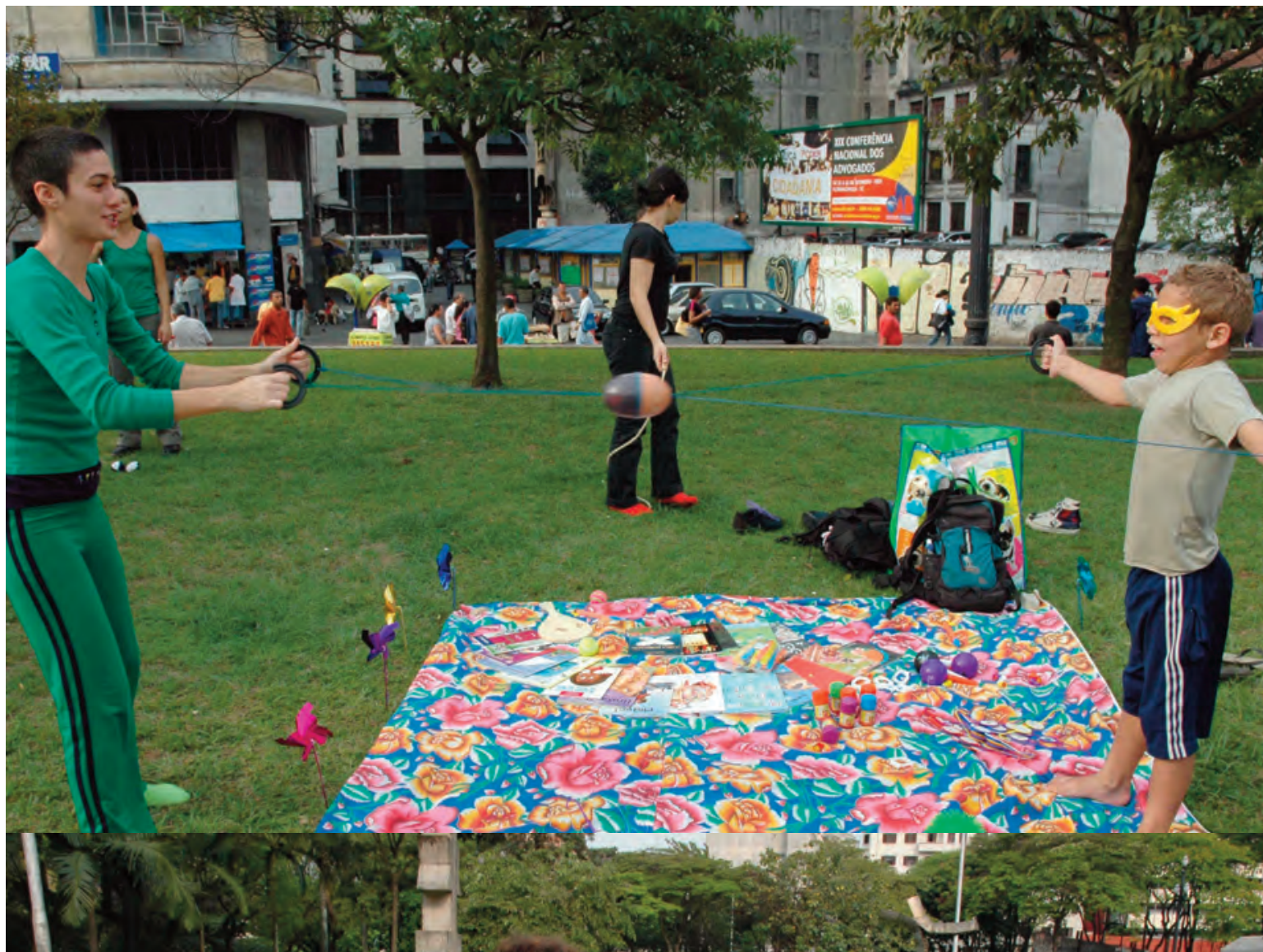

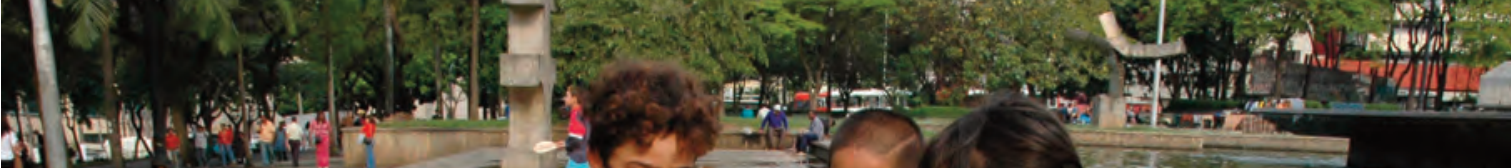

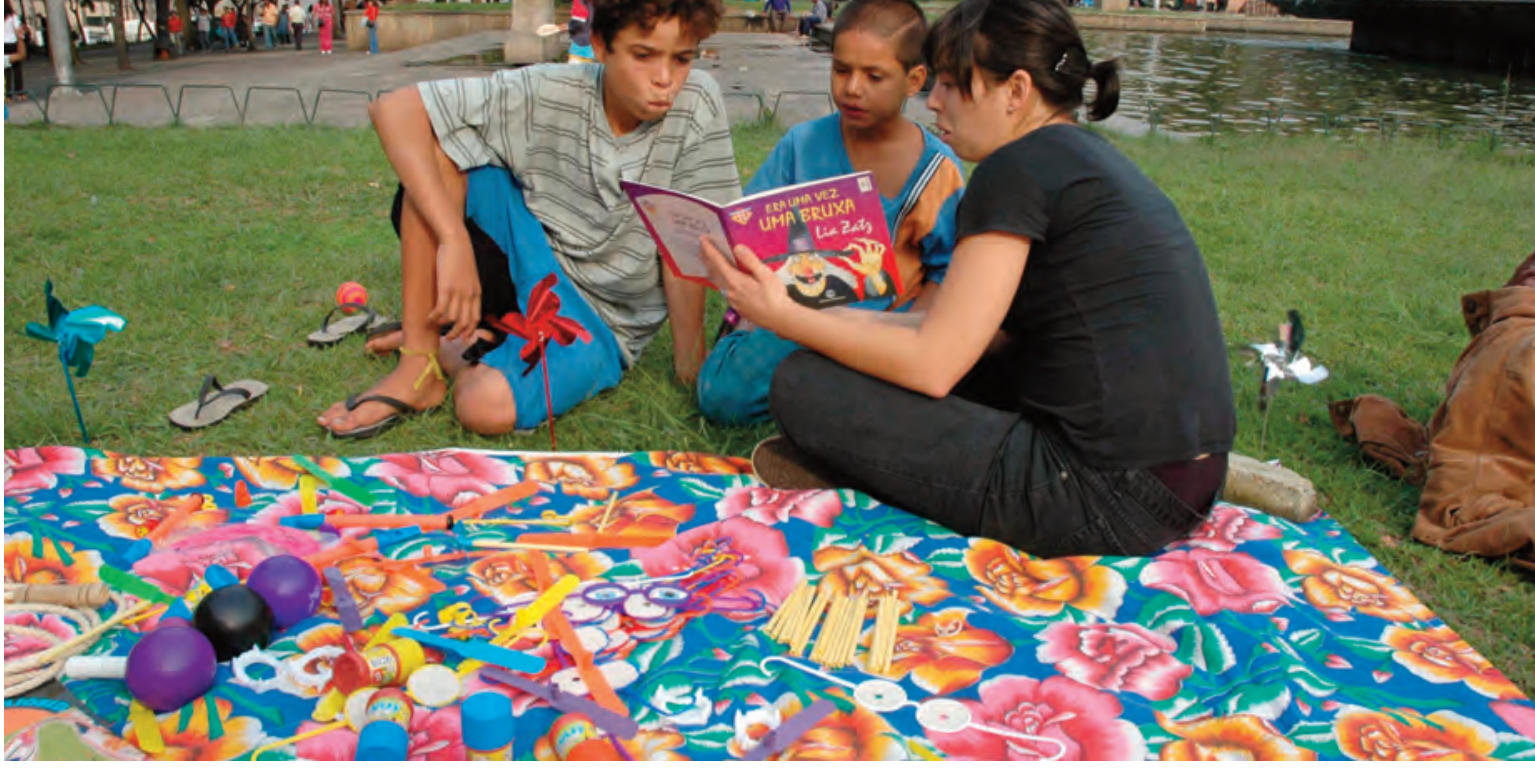

Crianças e Contrafilé na praça da Sé, São Paulo, 2005. 





Criança no balanço instalado pelo Contrafilé, Viaduto Okuhara Koei/Avenida Paulista; crianças fazendo pose de máscaras, centro da cidade; e Ato de Protesto contra a tortura na ex-FEBEM promovido pela AMAR e que contou com a participação do Contrafilé, São Paulo 2005-2006. 
PROJETO JO 08:Layout 1 7/25/12 11:45 AM Pagj 116

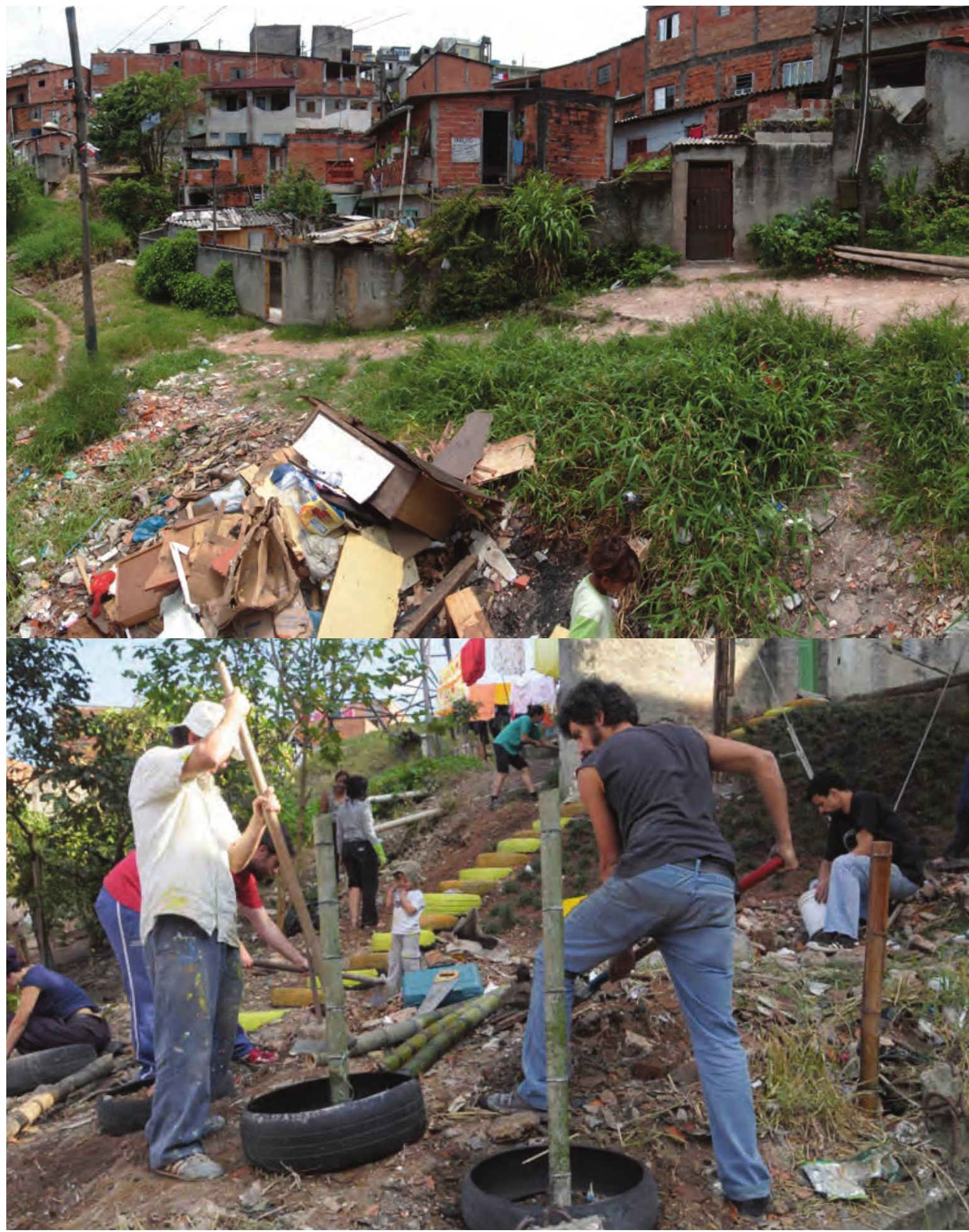

Parque para Brincar e Pensar, realizado pelo Contrafilé, Comunidade Brás de Abreu e Jardim Miriam Arte Clube (JAMAC, atelier-escola da artista Mônica Nador localizado no Jardim Miriam), São Paulo, 2011. 


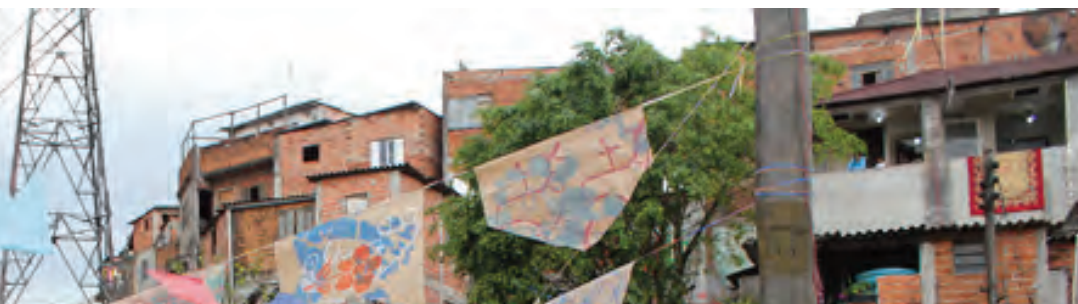

\section{$8=\mathrm{a} n \mathrm{~m}$} II. - and 1 II. I n

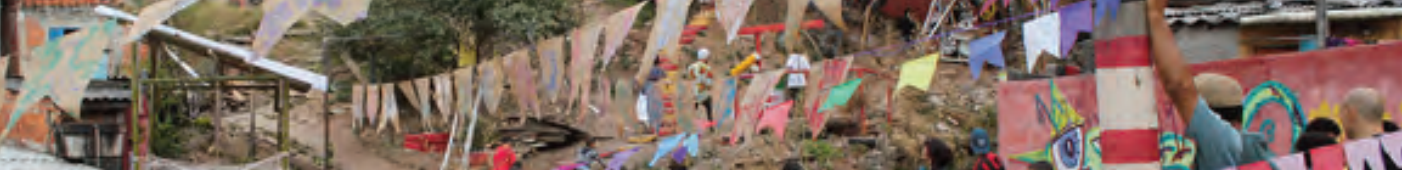

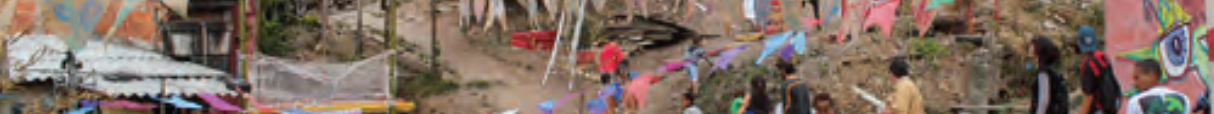

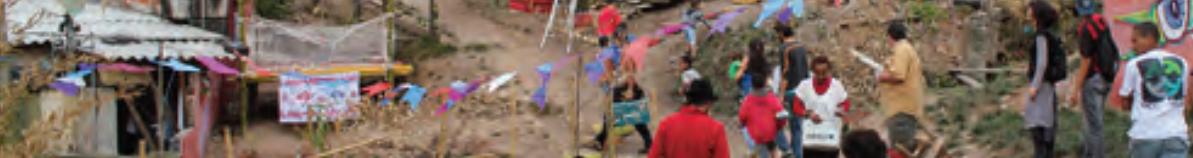
- the of then ?
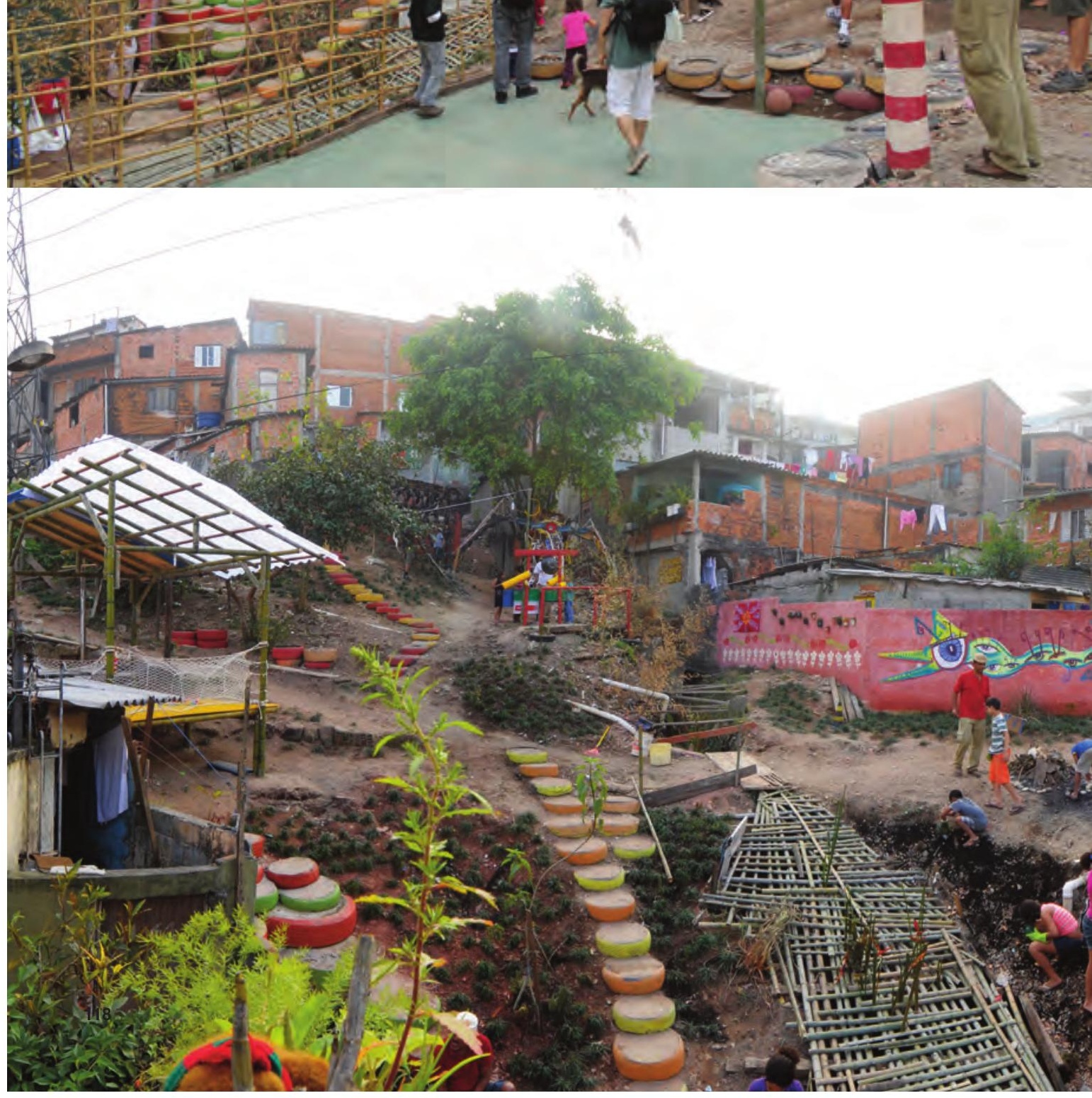
Trechos da publicação "A Rebelião das crianças" (Contrafilé, 2007):

Neste processo de encarnação dos conflitos, nos deparamos com a criminalização e o extermínio social de uma parcela enorme de crianças e jovens. ${ }^{44} 0$ dado de realidade que nos convocou a olhar com atenção para isso foi uma grande rebelião que aconteceu no início de 2005 na Fundação para o Bem Estar do Menor (FEBEM) - cárcere juvenil onde vivem cerca de seis mil crianças e adolescentes julgados como criminosos. Passamos a acompanhar diariamente as notícias sobre a rebelião, fazendo leituras críticas e coletivas de jornais. Até que começamos a substituir palavras para ver o que acontecia. Ao invés de 'juventude encarcerada', 'internos', 'menores', líamos: crianças. Assim, pudemos entender também que o que nos move, nossa urgência, é fazer constantemente esta operação de desnudamento dos fatos, o que nos levou a nomear este trabalho $A$ Rebelião das Crianças.

$$
[\ldots]
$$

As rebeliões na FEBEM denunciam para nós não a existência de uma 'juventude criminosa', mas a condição da criança (latu senso) como representante máximo do estado degenerativo da nossa sociedade. O olhar maniqueísta sobre a situação, a partir do qual ou se está 'contra ou a favor' do crime, 'contra ou a favor' da sociedade, reiterado pelos meios de comunicação, tipifica as crianças e jovens como 'ameaças'. É necessário, no entanto, antes de afirmar, perguntar: de que rebelião se trata?

$[\ldots]$

Para tornar público o que descobrimos no encontro com - 'circuito das crianças criminalizadas', pusemos em prática a idéia de 'assembléia'45, convidando três

44. Por exemplo, entre 2004 e 2006, morreram mais de 28 adolescentes que se encontravam sob a responsabilidade da FEBEM, segundo dados levantados pela AMAR - Associação de Mães e Amigos da Criança e do Adolescente em Risco. 45. Para "Assembléia Pública de Olhares", ver cap. 2. 
pessoas, referentes de diferentes lutas, para discutir problemáticas que ressoaram no grupo ao viver este processo: 1. A lógica que mina a potência de criação; 2. Tortura/terrorismo de Estado: o que significa a tortura hoje?; 3. Como re-significar traumas sociais e culturais que impossibilitam a construção de vida pública?

Conceição Paganele $e^{46}$ : Eu pensei: 'Que coisa é essa?!' Aí, ele veio e já começou a chorar. Eu vi muitos meninos chorando e muitas mães chorando. Ele falou: 'Aqui é terrível mãe! Aqui eles batem para valer, tem drogas, para você saber'. Eu disse: 'Não, meu filho, você precisa se tratar, ser curado dessa maldição'. 'Aqui tem droga, aqui tem tudo, aqui não vai mudar nada na minha história e eu só vou sofrer mais ainda aqui dentro. Se lá fora é ruim, aqui dentro é muito pior, tem de tudo que você possa pensar'. Na hora da saída, que eu queria abraçar, e ele com a camisetinha grudada. Eu queria olhar, ver se ele estava machucado, mania de mãe né?! E ele não me deixava, dizia que eu não podia. Porque tinha lá as normas deles, as leis. E quando eu ia sair dali, quase que ele não me larga de chorar, agarrado comigo, quase que eu não consigo ir embora. E saíam as mães chorando bastante também. Eu comecei a querer entender. Porque todo mundo chorava se era bem-estar? Todo mundo sai chorando? [...] Quando os meninos entram na FEBEM, as famílias ficam muito envergonhadas. A dor já era muito grande, já deixava paralisada. E ver o outro criticar e olhar então... Era uma dor muito nossa.

Maurinete $\operatorname{Lima}^{47}$ : 0 que se busca é destruir a potência juvenil e no lugar instaurar o ódio e a idéia de que existe um inimigo, um suspeito. É isso que o sistema não percebe. Fazem tudo isso com esses meninos e eles saem uma loucura, matando quem encontram na rua, pelo chinelo, pelo tênis. A vida se banaliza. É essa a história. Às vezes eu fico pensando que se come-

46. Mãe de um jovem que esteve na FEBEM e referência do movimento das mães contra a tortura nas prisões (AMAR).

47. Socióloga e integrante da Frente 3 de Fevereiro. 
çássemos retirando desses meninos o olhar de suspeita em todo o lugar em que ele vai, já estaríamos melhorando essa sociedade.

Conceição: [...] o processo de criminalização [da AMAR] começa quando o governador Geraldo Alckmin se declara meu inimigo. Ele vai a uma coletiva de imprensa e diz que eu não ajudo, que eu só atrapalho. Eles me acusam de ser a incitadora de rebeliões, fugas. Iniciam um processo legal contra mim, ainda não estou respondendo, porque está em fase de inquérito. [..] Eles tentam abafar quando a gente quer lutar por um direito totalmente negado, pelo direito de quem não tem direito nenhum. Eles matam a gente, porque socialmente eles estão me matando.

Suely: Mas é essa a forma como matam, por isso a gente precisa conversar uns com os outros para não morrer. Porque eles matam transformando uma coisa que é altamente digna, em uma coisa totalmente humilhante. E dão o nome de terrorismo. [...] Eu conheço profundamente a fragilidade que a Conceição ficou, e sinto isso como uma coisa totalmente comum entre a gente. $\mathrm{E}$ aí também tem um trabalho de descobrir onde que essa fragilidade ecoa, onde essa humilhação ressoa na história de cada um. Porque a humilhação tem sido, sistematicamente, uma estratégia do poder para cancelar os movimentos de ampliação. No começo, eu estava tentando entender o que estou sentindo, e a Conceição me ajudou. É humilhação mesmo. E hoje, a humilhação está chegando de outro jeito não só no Brasil, mas no mundo inteiro. Na França, por exemplo. Lá, a televisão tem muitos programas de falação. Antes, tinha gente de movimento, gente de direita, de esquerda, todo mundo discutindo. Hoje, você olha esses programas e está todo mundo falando a partir da ordem estabelecida. E sempre tem um ou dois, que são sempre os que estão verdadeiramente pensando e fazendo política, que não são atacados, ninguém vai chegar e dizer: 'A Concei- 
ção é criminosa', 'a Suely é criminosa'. Não. 'A Conceição é gracinha' e, olha que ridículo, que jeito mais antigo e ultrapassado de dizer as coisas. É humilhante, mas é uma humilhação que está usando outras estratégias. Neste caso, absorve e não ataca. É diferente do que a Conceição está contando. Mas o que eu quero dizer é para pensarmos quando a humilhação acontece com cada um, e vai bater na memória de sei lá que outra experiência, o que torna a gente mais impotente e frágil e a gente não consegue sair desse ciclo, até para poder pensar sobre isso, como estamos pensando agora. O que eu vejo de situação comum aqui é isso, que não depende de qual tipo de batalha que cada um está levando adiante, da encanação de cada um ou da história de cada um. Eu sinto essas formas de humilhação como um elemento totalmente comum que vai deixando a gente nesse Estado de Confinamento.

$$
[\ldots]
$$

Contrafilé: Eu vou falar um pouquinho o que eu estou pensando agora. O Contrafilé trabalha pensando determinadas situações que partem da nossa experiência e tentando sistematizar o pensamento; e sistematizamos o pensamento também quando produzimos símbolos, intervenções na rua. E a gente vem desenvolvendo um trabalho a partir dessa angústia do "confinamento", que não é a de estar dentro de uma prisão, mas de sentir o confinamento como um estado geral que chega até nós e atravessa a nossa experiência.

Suely: Então, não é só o confinamento dos outros, mas também quando vocês se sentem confinados.

Contrafilé: Sim, é também como a gente se sente confinado. E aí, eu acho que o confinamento tem a ver com várias coisas. Tem a ver, por exemplo, com a dificuldade de se relacionar com o outro, o outro que se configura sempre como um outro distante e como, do 
nosso lugar, isso vai se configurando. E eu acho que deu vontade de quebrar um pouco também esse confinamento, esse lugar de elaboração e de 'pensar confinado', sempre entre a gente. Deu vontade de abrir isso e de misturar pessoas com experiências diferentes de confinamento. Como, juntos, podemos misturar experiências para pensar, para ampliar o entendimento disso?

Suely: Eu estou sentindo um tipo de confinamento que para mim é novo. Eu não sei se vou conseguir falar direito dele ainda. Nos últimos anos, eu estava sentindo um movimento de desconfinamento, eu estava sentindo que tinha um monte de gente pipocando em um monte de lugar. Eu trabalho muito fora do Brasil e dentro, vou e volto. Eu sentia que tinha gente em vários lugares em um movimento de criação, vendo o que estava se passando e buscando estratégias para combater, pensar, entender. E agora, recentemente, eu estou sentindo que muito do que foi pensado, falado, apresentado, daquilo que está sendo comunicado é imediatamente incorporado por um discurso oficial e totalmente esvaziado do movimento vital e das tensões que levaram a pensar as situações reais; da experiência de coisas intoleráveis que estamos vivendo. Esvazia e muda a direção da palavra. Aí, vira uma coisa 'superbacana', quando na verdade são palavras que falam das coisas complicadas, dos problemas que se está vivendo que você tem que enfrentar. As palavras estão aí, mas não o conteúdo delas, a experiência não está mais nelas. E essa experiência que se estava vivendo ao inventar essas palavras, é completamente anulada, neutralizada. O que predomina não é - que essas palavras significam, mas a falcatrua absoluta, a violência absoluta e total de exploração e dominação.

Maurinete: Agora, para mim, o que eu sinto, no meu caso de confinamento, é que existe um medo, o medo de 


\begin{abstract}
imposibilidad de hacer de la enunciación una simple convención, una simple instituición, una simple confirmación de las relaciones sociales ya instituídas (Lazzarato, 2006, 23-24).
\end{abstract}

É, portanto, a partir do embate entre representação e contrarepresentação, que uma atualização da dimensão pública do espaço se dá como desdobramento imprevisível. Podemos aqui nos reportar ao conceito de "espectador emancipado" de Jacques Ranciére que, segundo Vera Pallamin:

\title{
[...] defende uma recusa dessa distância radical, dessa distribuição de papéis e das fronteiras entre esses territórios do ver, fazer e falar. É preciso, ele afirma, reconhecer a atividade própria do especta- dor, que é a de tradução e contra-tradução daquilo com o qual se depara: é neste poder de associar e dissociar que reside a emanci- pação do espectador, quer dizer, a emancipação de cada um de nós como espectador. Nisto verifica-se uma capacidade que faz cada um igual ao outro e que se exerce 'pelo jogo imprevisivel de asso- ciaçôes e dissociaçōes' (2010, p. 8).
}

Se entendemos a emancipação do espectador como a capacidade de se dar ao direito de produzir enunciaçôes, em muitos dos trabalhos aqui apresentados vemos isso acontecendo na medida em que o "autor" coloca-se sobretudo como um "espectador emancipado público", aceitando o risco de expor as suas próprias intensidades no sentido de qualificar o debate. Muitas vezes esse movimento é, em si, compreendido como "a" intervenção. Paolo Virno, pensador italiano, acredita que: 
Sobre todo al interior del movimiento new global, el rol de la 'tercera persona', del público, es, ya de por sí, una forma de intervención activa. Hoy, quien escucha una ocurrencia o un discurso político, lo rearticula mientras lo escucha, elabora sus desarollos posibles, modifica su significado: en sinteses, lo transforma en el momento mismo en que lo recibe. Tiene que ver, en fin, con un público activo (2006, p. 15).

Assim, estamos aqui problematizando o papel do próprio "artista" enquanto "público ativo de si mesmo e das relações com o seu entorno", que o podem levar a uma elaboração dos modos de vida contemporâneos e a enunciações críticas. Uma problemática que constantemente atravessa as enunciaçóes coletivas tem, justamente, a ver com a dificuldade de sair do lugar de "espectador passivo", "alvo" do pensamento contemporâneo defensivo, já que para ativar se enquanto espectador-autor no sentido em que estamos entendendo o espectador aqui, é necessário, como vimos, a conexão com a própria fragilidade. Essa dificuldade é vista pelos coletivos como uma das responsáveis pela impossibilidade de construção coletiva da vida pública e da cidade (em suas escalas materiais e imateriais), na medida em que o medo de entrar em contato com esse devir, esse fora que nos fragiliza, transformando-se a partir dele, vira "medo do outro". Que "outro" é este do qual se fala?

No livro "Ninguna Mujer Nace para Puta", Maria Galindo e Sonia Sanchez (2007) usam a imagem da relaçáo proibida como uma força subversiva interpeladora para falar dessa ruptura subjetiva que ativa conexões entre mundos e o trabalho de tradução e contratradução, a partir do qual espaços de compreensão se tornam possíveis: "Es un lugar prohibido y por eso puede ser muy subversivo, porque 
romperia con la forma más profunda de control y de poder de un ser sobre otro" (p. I65-195). As autoras ainda dizem que a força subversiva não vem simplesmente da enunciação das diferenças, mas da passagem para um lugar mais elaborado, no qual esse tipo de aliança proibida se concretiza a partir de um "cruze de miradas" (intercâmbio de olhares). 


\section{Metáforas do Confinamento}

Se vem para me ajudar, não se dê ao trabalho, porém se vem porque a tua libertação está vinculada à minha, então trabalhemos juntos (Lilla Watson, aborígene australiana).

Um outro elemento da linguagem construída por esse tipo de prática crítica aqui analisada, poderia ser descrito mais ou menos assim: sair desse estado defensivo em relação a um outro supostamente externo e ameaçador convocando um estado ativo do corpo, que se coloca no centro das situações mais tensas para perguntar: Tenho medo do que? Onde está a minha fragilidade, o que ela significa? O que aquilo que está acontecendo lá longe, diz de mim? Como diz o GAC:

Sería un verdadero desafío para todos nosotros indagar qué nos hace frágiles y cómo se construye la fragilidad colectiva, qué hacer con el miedo que sentimos a lo desconocido, o cómo dialogar con otras realidades que no son las propias, que nos resultan enigmáticas, desde una actitud inclusiva o analitica, intentando despojarnos de los romanticismos que la militancia supone. También puede resultar interesante preguntarnos por qué encajamos donde encajamos, ya sea que estemos en el lugar del delincuente o en el de su presa (GAC, 2009, p. 137).

Muitos trabalhos tentam encontrar formas para falar disso: a 
experiência visível e sensível de viver em uma "sociedade de controle"; acompanhada da experiência invisível, disforme, de nos sentirmos, cada um de nós, auto-confinados nesses lugares pré-destinados, nas identidades fixas, aceitando passivamente os "discursos do medo"49 sem, no entanto, conseguirmos agir.

A criação da metáfora do "Estado de Confinamento" e de uma "Secretaria do Estado de Confinamento", formalizada pelo grupo Contrafilé e utilizada pelo coletivo Política do Impossível (PI) em seu trabalho "Cidade Luz - Uma investigação-ação no Centro de São Paulo" ${ }^{\circ}$, fala justamente de um Estado que ao mesmo tempo em que se revela como norma social, amplia e aprofunda um estado anímico de isolamento e solidão nos corpos individuais.

A investigação-ação, a partir da qual é possível identificar como acontece a "espacialização desse Estado de Confinamento" é, segundo o PI:

\begin{abstract}
Uma forma de nos relacionarmos com nosso próprio contexto, onde o investigado não se objetualiza para ser tratado analiticamente. A investigação parte de nós mesmos como subjetividades situadas e em ação. A ação é uma postura que inicia o diálogo, a partir da qual convido o outro a se somar à conversa. Essa ação a partir do nosso próprio lugar se dá através da criação de representações (soluções plásticas) e de ir vendo como as imagens que vou produzindo dialogam com o mundo onde vivo (PI, 2006).
\end{abstract}

49. Segundo Teresa Pires do Rio Caldeira, nas cidades contemporâneas, diferentes classes sociais, especialmente as mais altas, têm usado o medo e a violência do crime para justificar novas tecnologias de exclusão social e a retirada de classes mais baixas dos bairros tradicionais das cidades. A circulação dos "discursos do medo" é, para a autora, parte de uma fórmula que elites do mundo todo vêm adotando para reconfigurar a segregação espacial das cidades (Caldeira, 2000). 50. Que resultou em uma publicação realizada com o apoio do Minc/Funarte, São Paulo, 2008. 
Nesse trabalho, o Centro de São Paulo é entendido como um espaço simbólico do conflito entre a necessidade de conviver e produzir espaços coletivos a partir da diferença e a imposição de uma vida "lisa" ${ }_{11}$, "limpa", homogênea e sem conflitos. Os fenômenos que têm acontecido no Centro ${ }^{52}$, portanto, condensam uma série de situações estratégicas para falar sobre quem somos, o que queremos, o que podemos, o que não podemos, enquanto sociedade. Na época em que o trabalho foi feito, essa escolha foi marcada por esse tipo de indagações, que partiam dos laços afetivos e subjetivos que fazem desse, um espaço social simbolicamente potente para todos nós.

Portanto, a tentativa, a partir do aprofundamento em uma situação exemplar de "Confinamento Social", foi a de percorrer e discorrer sobre a situação do "Centro da Cidade" como um "centro de nós mesmos". Ou seja, de criar uma outra perspectiva de leitura que trouxesse à tona uma interpretação na qual o grupo pudesse romper as fronteiras discursivas para anunciar aquilo que via, sentia e pensava, renovando a sua própria circulação pelos espaços físicos e simbólicos e criando outras condições para a imaginação coletiva sobre aquele mesmo lugar (o Centro de São Paulo).

O PI também problematizava ali as formas atuais de ocupação do território (tais como os condomínios fechados, as prisões e as ocupações dos movimentos de moradia), os espaços que se espelham e estão diretamente ligados à "experiência do público" como a vivemos em nossa atualidade.

A partir de tudo isso, uma multiplicidade de práticas, tais como intervenção direta na cidade, entrevistas, cartografias, interferências gráficas em discursos da mídia, imagens poéticas, se so-

51. A respeito dessa ideia, Suely Rolnik diz o seguinte: “Estamos diante [aqui, se refere à sociedade atual, que define nesse texto como 'pós-fordista'] de um novo élan para a idéia de paraíso das religiões judaicocristãs: miragem de uma vida lisa e estável, sob perfeito controle. Esta espécie de alucinação tem sua origem na recusa da vulnerabilidade ao outro e das turbulências desterritorializadoras que provoca" (Rolnik, 2006, p. 7).

52. Especialmente o "Projeto Nova Luz", baseado na expulsão da população pobre do centro e no processo de gentrificação daquele território. Para saber mais, ver "Cidade Luz" (PI, 2008) e Beatriz Kara José (2007). 
maram para tentar dar conta de reverter a forma passiva e estabilizadora das interpretações geralmente construídas a respeito daquele contexto. Esse foi um trabalho completamente colado com a atualidade de um processo social em curso e que tentou captar a dimensão "microssociológica" como resultado de uma série de confluências e invençôes. O livro "Cidade Luz", enquanto cartografia, foi uma tentativa de captar o social como um processo constitutivo que acontece a partir do concreto e das múltiplas subjetividades nele envolvidas; de ser uma voz subversiva naquela miríade, que partia do desejo da emancipação e contaminação e de fazer esse desejo de mobilidade e circulação pelos territórios de si e da cidade, proliferar ${ }^{53}$.

Essas leituras alternativas de fatos sociais hegemônicos acabam, por sua vez, reverberando socialmente por conter, justamente, na escala da experiência, a possibilidade de estabelecer conexôes inusitadas, que ampliam as "sinapses possíveis" e revertem as leituras estereotipadas da "realidade" ao introduzir uma representação que contém a consistência processual de "espectadores que se fazem públicos", para tornar visível uma experiência singular de um contexto comum.

Trechos da publicação "Cidade Luz" (PI, 2008):

\section{Introdução}

A decisão de centrar o trabalho sobre os conflitos sociais, políticos, econômicos e simbólicos que apresenta o Bairro da Luz, abriu a possibilidade de atuar no bairro ao mesmo tempo em que começamos a dialogar com uma problemática muito mais extensa que transpassa os limites da própria Luz. O Centro - e, em especial, a região denominada 'cracolândia' - revela para nós, por sua densidade, questões constitutivas dos processos de subjetivação de todos nós na rela-

53. Retomando a conversa com Suely Rolnik na Introdução desta dissertação, não estamos aqui "celebrando a mobilidade" incondicionalmente. Sempre que falo em circulação ou mobilidade, estou entendendo-as como uma construção, uma conquista de ruptura com padrões internos e externos de comportamento e, portanto, a partir de uma perspectiva crítica e não como "moda" ou "tendência" - pois vistas assim, essas se adequam completamente ao capitalismo em sua versão contemporânea. 
ção com esta cidade. Nesse microcosmo da 'velha nova luz' nos encontramos com as tensões da cidade esticadas ao máximo: um estado que de um dia para outro se propõe como 'o grande reparador', 'o salvador' de uma situação de violência que ele mesmo provocou. Mas que, ao contrário do esperado de uma reabilitação do centro, inventa uma nova 'disneylândia' no lugar da velha 'cracolândia'.

Territórios em Disputa: Conversa com Raquel Rolnik ${ }^{54}$ (trechos da conversa)

PI - Queríamos conversar com você sobre o processo de revitalização do centro de São Paulo, especificamente do bairro da Luz, sobre o que isso significa para a cidade, para as relações humanas, concreta e simbolicamente [...]

Raquel - [...] Revitalizar pressupõe a idéia de ter alguma coisa morta, o não reconhecimento da vida que existe, e normalmente a vida é de pessoas pobres, de gente que justamente ocupou aquele lugar porque ele perdeu $\circ$ interesse para o mercado imobiliário, perdeu preço e virou um lugar que pode abrigar quem não tem dinheiro para participar do mercado, ou que participa com relações muito mais informais e irregulares. Então, funciona dessa forma: prostitutas, camelôs, encurtiçados, desempregados, catadores, enfim, pessoas que existem, são reais, mas é como se não existissem. Existe uma metáfora usada, do organismo humano, que eu acho uma loucura, tratam alguns lugares da cidade como se fossem 'cânceres' mesmo, 'cancros urbanos', eles têm nojo do lugar.

$[\ldots]$

54. Arquiteta e urbanista especializada em planejamento e gestão da terra urbana. É professora da FAU-USP e Relatora Especial para o Direito a Moradia do Conselho de Direitos Humanos da ONU. Foi diretora de Planejamento da Cidade de São Paulo (1989-1992), Secretária Nacional de Programas Urbanos do Ministério das Cidades (2003-2007), e Coordenadora de Urbanismo do Instituto Pólis (1997-2002). Prestou consultoria a governos, organizações não-governamentais e agências internacionais, como UNHabitat, em política urbana e habitacional. É autora dos livros "A Cidade e a Lei", "O que é Cidade", além de vários outros artigos e livros sobre a questão urbana. Colabora regularmente com a imprensa em temas de urbanismo, tendo mantido programa diário sobre o tema, na rádio CBN SP, Rádio Nacional e na BandNews FM. Conversou com os integrantes do PI em 2008. 


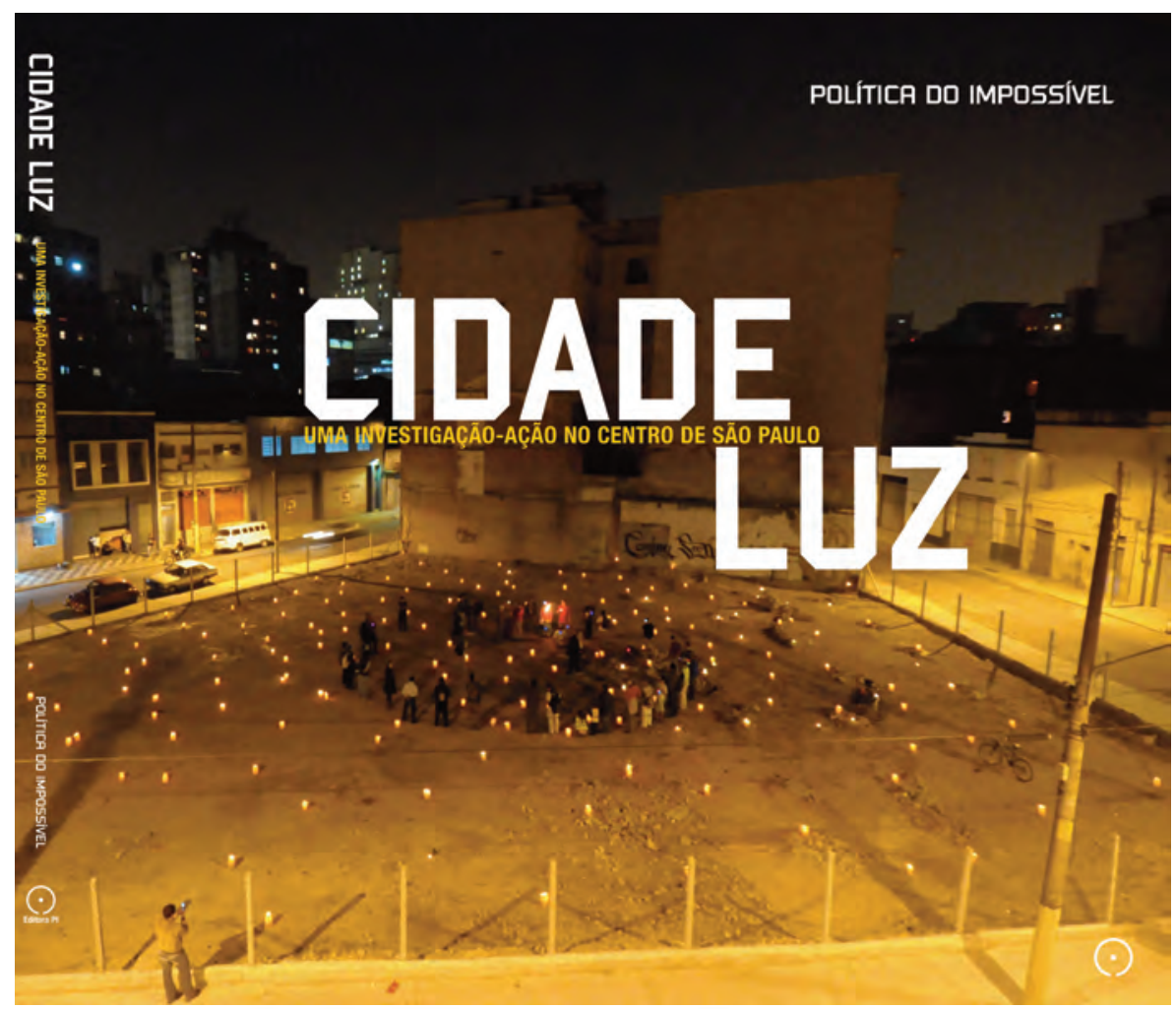

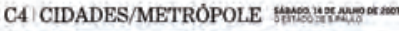

\section{Demolição da Cracolândia terá início este ano}

Pelo menos 1 das 23 quadras deve ir ao chăo; governo já possui 3 imóveis na área e tem outros 10 na mira

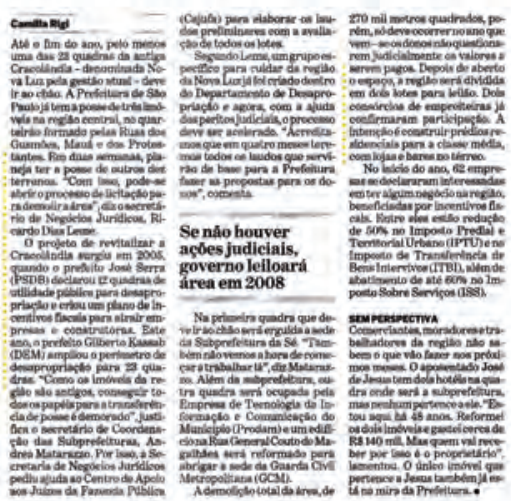

\section{Uma maravilhosa agulhada na "cracolândia"} GILBERTO DIMENSTEIN

Aos 67 anos, sem pretensbes eleitorais daime Lenner, renomado mundialmente devido as experiencias que desemolvev en Cumiliagresolveu dedikar-se ao

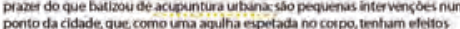
terapenticos. Elevem recebendo combites de peefeituras, dentro e fora do Brasil.

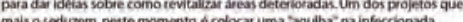

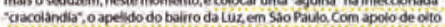
grandes construtoras desen hou um plano para lazer daquete bairo ima especie de incubadora de at istas e de empress de tocnologia da intormerto.

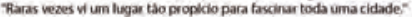

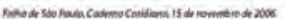

\section{O futuro da Nova Luz já começou \\ Oprojeto Nova Liz ja e ima realidade. Neste mis de outubro de 2007,23

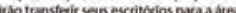

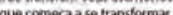 definitivamente em um novo tainto de Sato Paubo L) a Lurera uma mancia nega que irradiava degradaçào no entorno, onde poucos tínham esperanca

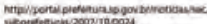

\section{Nova Luz: \\ projeto năo vence a Cracolândia}

Desapropria, demolit e tecomesa do zero. Essas medidas sto a base o projeto Nova luz :

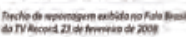

\section{Nova Luz} no velho centro

Osesietario de Seguransa Poblica Ronaldo Marzagda afirmou ins

dos piélios que eviste a disposicáo de reforcar a seguranca para recuperaça porstvel" (..)

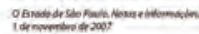

\section{Para Kassab,} cracolândia năo existe mais

O prefeito Galberto Kassab (DEM afimou ontem que a regiso conhecida como cracoland nsoexiste maks.

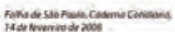




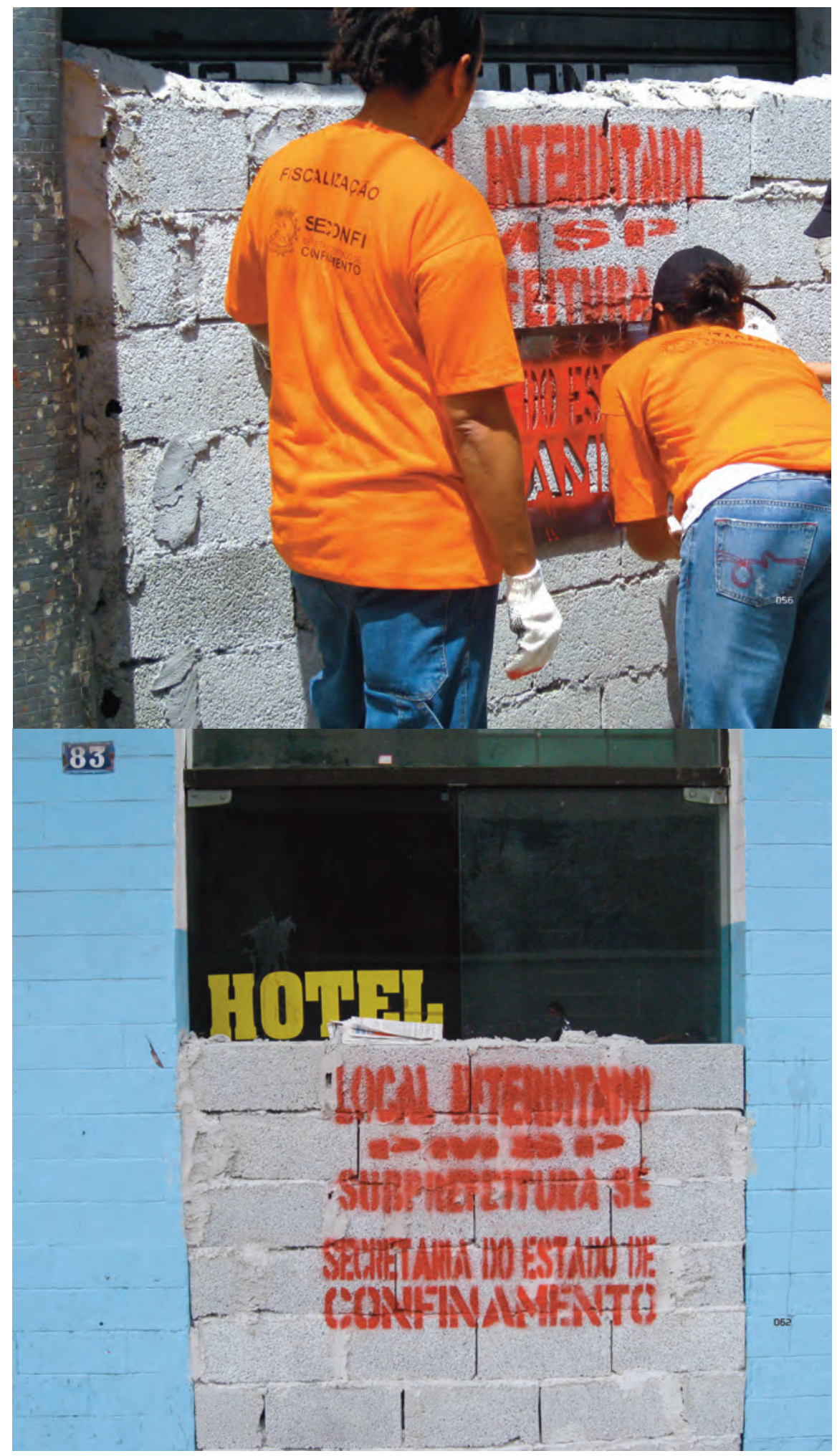


PROJETO JO 08:Layout $1 \quad 7 / 25 / 12 \quad 11: 45$ AM Pagg 136
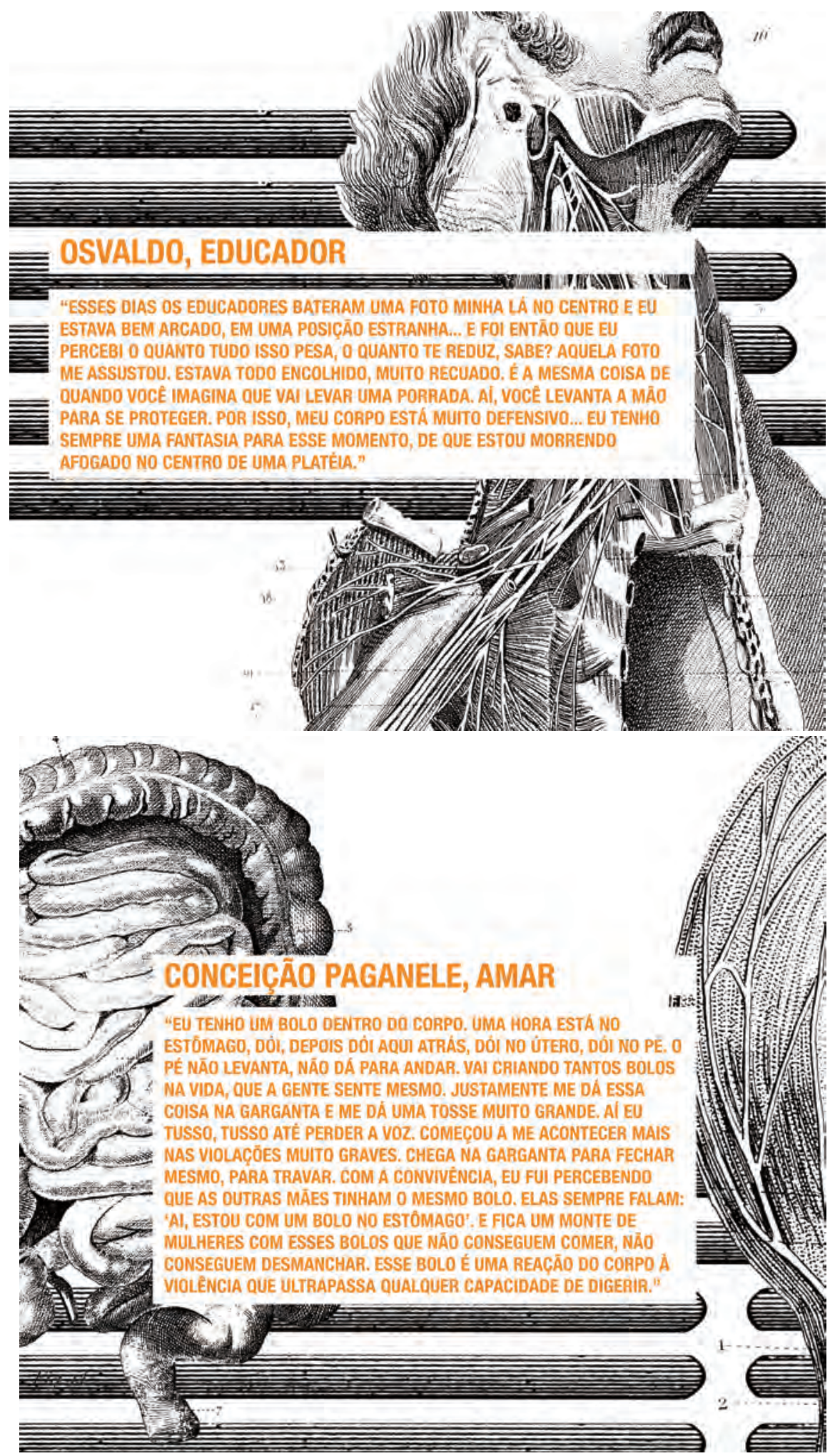


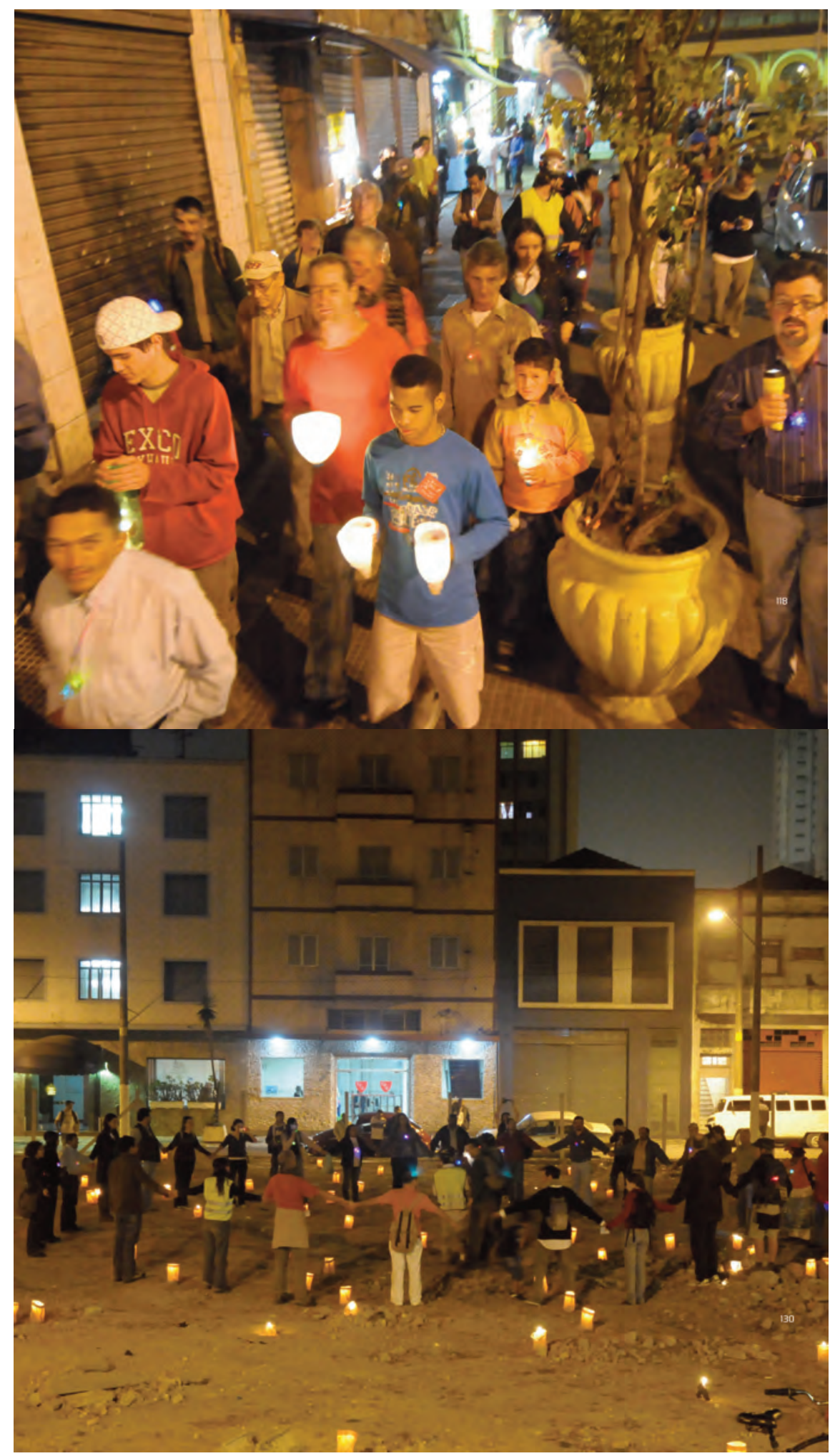


PI - É interessante ver como São Paulo reproduz claramente esta lógica de parceria entre o Estado e a iniciativa privada. Quando a gente vê este cinturão periférico que vai se formando e se tornando cada vez maior na cidade, percebemos que permanece no Centro uma espécie de ponto que ainda não se conseguiu 'exterminar'. Tem um educador que participa desta nossa pesquisa que, pensando nestes termos de linguagem, em como impregnamos uma série de valores quando falamos "cracolândia", chama de manifestação de resistência os meninos usando drogas naquele espaço. Mesmo reconhecidos pelo poder público como um problema urbanístico - ao ser demolido o bairro os meninos devem desaparecer - mesmo assim, estes meninos resistem, mesmo com toda a força policial, com a mídia reforçando o problema, o policial indo lá e batendo de novo, todas as ONGs tentando fazer este processo de expulsão, não à força, mas levando pela mão, mesmo assim eles voltam e voltam. Esse educador chama isto de manifestação de resistência, no sentido de que tem ali uma outra leitura a ser feita.

Raquel - Eu acho que dá para fazer uma leitura da cidade como um todo desta forma, todo território da cidade é disputado permanentemente, do Centro às periferias. Claro que do lado do setor imobiliário, e que também não é o único, são muitos os que disputam o mercado, não é uma oposição biunívoca, ou seja, mercado imobiliário versus páreas urbanos ou marginalizados ou excluídos, não é, as relações são muito mais complexas que isso, e os territórios estão em disputa permanentemente. O que eu acho mais impressionante em São Paulo é a força desta dinâmica, ela é muito intensa. E já começou assim, é a lógica do Bandeirante; e o que é o Bandeirante, símbolo de São Paulo? É um cara truculento, bandido, que veio ganhar riqueza fácil a qualquer preço; por outro lado é o cara que entra na mata, enfia o pé na lama, fala Guarani per- 
feitamente - no século XVII só se falava guarani nesta cidade -, se mistura com as índias, mora na rede debaixo da árvore, não é um fidalgo que nunca se misturou. É isto que é São Paulo, essa força de construir e de destruir também. Tudo que a cidade é hoje você pode pensar tanto do ponto de vista do Matarazzo: ' $O$ Centro virou um câncer'. Ou do ponto de vista desta outra leitura: 'o Centro é um foco de resistência política'. [...] Esta coisa da droga é uma coisa complicada porque o comércio de drogas, assim como os outros comércios irregulares e ilegais que têm em São Paulo, como o contrabando e a pirataria, com seus distintos níveis de criminalização, também faz parte da história da ambiguidade constitutiva do Estado brasileiro e da gestão urbana brasileira, essa ambiguidade entre - legal e o ilegal. Tanto que a maior parte da cidade é produzida irregularmente e ilegalmente. A periferia inteira é autoconstruída, autoproduzida pelas próprias pessoas sem ou fora da norma. Não somente as favelas, mas os loteamentos irregulares, clandestinos e os puxadinhos, esta é uma cidade de puxadinhos. Embora seja tudo ilegal, por que não está todo mundo preso? [...] A gente precisa do legal e do ilegal, isso faz parte da cultura política, da relação que a gente tem com a lei. Esse modelo republicano de democracia que foi montado na Europa por aquela sociedade, para aquela sociedade, quando vai ser exportado para o mundo, como que ele chega na América Latina? Como isso é implantado aqui? Como ele é implantado na África? Como é a relação com o que tem lá? Como ele chega na Ásia, na relação com o que tem lá? Vai sendo absorvido e transformado pelos modos de funcionamento locais. Então, aqui tem mesmo uma tensão permanente entre o legal e o ilegal. Não se constituiu no Brasil a idéia, a noção de que você tem uma lei, uma norma que foi fruto de um pacto social e que, portanto, ela tem que ser implementada em nome deste pacto. Porque nunca teve pacto! Sempre foi meia 
dúzia. Meia dúzia e o resto vai se virando. $\mathbf{E}$ todo mundo usa a lei ou a não-lei dependendo das circunstâncias, o próprio Estado. Por que o Estado tolera a autoconstrução, a irregularidade, a ilegalidade? Porque sabe que pra manter concentrada a renda e o poder, este é o jeito. Mas de vez em quando vai lá e tira a favela dizendo que "é ilegal". Então mobiliza o ser legal ou o ser ilegal em função das necessidades do momento e das conjunções de construção de opinião. E é isso, os circuitos da ilegalidade, de irregularidade, como o tráfico de drogas, também vão entrando e penetrando dentro dos territórios que de alguma forma estão menos conectados e regulados pela norma. Então, não é à toa que a favela seja um centro de tráfico de drogas. Por que a favela? Porque ali já é um espaço pouco normatizado, pouco regulado, onde a lei existe, mas é mais tênue a presença dela; não é que o Estado não existe lá, ele existe completamente, só que de outro jeito. Então, o Centro, as áreas que por alguma razão urbanística acabaram sendo desinvestidas pelo mercado e acabaram fisicamente se deteriorando e sendo abandonadas, vão sendo ocupadas por estes circuitos que se instalam ali, meio na margem, mas que também fazem parte, também vão migrando. $E$ é gozado que, nessa política, que o pessoal chama de higienista, que está sendo feita no Centro, se intervém para tirar na força. Evidentemente que aquilo vai vicejar em outro lugar. A menos que você assassine as pessoas, e isso acontece também. Eu tenho plena consciência de que se trata de uma causa complexa, é muito difícil. Mas ao mesmo tempo eu acho que é muito importante ter a idéia de uma reabilitação includente, uma reabilitação para os que estão aqui, para nós. E "nós" significa uma maioria pobre sem recurso. É uma utopia importantíssima para construir uma visão e um pensamento de cidade includente, porque isso é o mais difícil. A situação do Centro não é difícil porque o Centro é complexo, mas porque nós temos um modelo de 
cidade segregada, de apartheid, que constituiu nosso modelo de desenvolvimento urbano. Então, eu acho que a intervenção na área central é uma chance de ruptura com o modelo do apartheid, de mostrar que esta ruptura é possível, de que ninguém vai morrer se conviver com os pobres do outro lado da rua. Pelo contrário, é uma aposta de que isso pode produzir uma cidade menos tensionada do ponto de vista da violência das relações, uma cidade menos rasgada do ponto de vista do tecido sociopolítico territorial que é tão fragmentado, que chegou no limite. Eu sinto que tem uma certa disposição dos cidadãos paulistanos, pelo menos de uma parte dos cidadãos, inclusive da elite, que já não aguenta mais viver com medo. E pra quem a solução de carros blindados e seguranças não satisfaz do ponto de vista humano. [...] Que é a relação, a idéia do território como espaço vivido e construído e pactuado por quem vive ali. Um pacto territorial! [...] Nós temos 40 anos de urbanização, 50 no Brasil, acho que com cem anos de urbanização talvez possamos construir uma outra relação do cidadão com o território no sentido de auto-constituição, porque $\circ$ que não aconteceu foi o cidadão se auto-constituir na medida em que o território se constituiu. A idéia de público, de dimensão pública, é o reconhecimento do lugar que cada um ocupa dentro desse público. Mas que público é esse no qual o público não tem lugar?

\section{Conclusão}

A história do grupo Política do Impossível contra a Secretaria do Estado de Confinamento é uma história de resgate metafórico daquilo que está sendo vivido por nós mesmos no embate com a cidade de São Paulo, uma forma de questionar as relações sociais nas quais nos encontramos muitas vezes imersos, sem nos darmos 
conta. A escrita desta história é, em si, uma tentativa de compreender, coletivamente e através do desenvolvimento real de ação e pensamento, sensações e urgências que em um primeiro momento podem parecer individuais.

Este tipo de narrativa pretende criar símbolos que condensem estados comuns e latentes de ânimo, que atravessam a sociedade independentemente de questões de classe e nos permitem estabelecer parâmetros criativos para o diálogo. Se isso acontece, é possível romper as redes de relações estabelecidas e dar passagem a novas tramas de relações, sendo a ruptura, aqui, um projeto de reconstrução coletiva de discursos, portanto, de representações. A construção de discursos se dá de diversas formas (nos meios de comunicação, nas publicidades, na educação, na internet, etc.) e nunca deixa de ser ideológica, de formar as visões do mundo onde vivemos. Estamos acostumados a receber estas configurações de nossa própria vida como naturais. Assim, vamos organizando nosso modo de ser: através de relatos que constroem identidade; em última instância, constroem a identidade nacional. Qual é a história que se relata do lugar onde vivo? Fazer este tipo de pergunta é começar a construir a nossa cartografia de relações, o que nos permite, a partir daí, criar nossos próprios símbolos, nossas representações do mundo no qual vivemos e no qual poderíamos viver. Não à toa acreditamos ser a construção simbólica nosso lugar de resistência: pois ela tem a potência de interferir na narrativa social, de gerar - por mais mínimos que sejam - deslocamentos na configuração estabelecida do possível; é uma intervenção na comunicação.

Aqui, invoco o sociólogo Gabriel Tarde, quando fala sobre a relação entre diferença e semelhança: as minúsculas inovações ordinari- 
amente anônimas são, para ele (que escrevia no século XVIII!), o que movem a produção do social, sendo que essas passam a contaminar o tecido social através da repetição que se dá pela vibração (potência desejante) contida nessa capacidade de diferenciação. A imitação, no entanto, nunca é exatamente igual àquilo que imitou, sendo constituída pela singularidade e subjetividade daquele que imitou e "Qualquer repetição, social, orgânica ou física, não importa, isto é, imitativa, hereditária ou vibratória [...], procede de uma inovação [...]; e assim o normal, em toda a ordem de conhecimento, parece derivar do acidental" (Tarde, I976 apud Themudo, 2002, p. 27 )55.

Dessa forma, do que vimos e pensamos até agora, não será a ação concreta e anônima na cidade, transformada em imagem que cir cula, uma forma de circunscrever, tornando visível, esse momento diferencial de relação com o espaço - que depois afeta pela força do desejo e da crença, mais ou menos contidos na representação que se faz desse instante inaugural do acontecimento? A metáfora do confinamento, trabalhada de diferentes formas pelos grupos, pode ser compreendida, portanto, como a própria imagem de uma semelhança que se inicia na diferença, ou seja, nessa experiência de rebeldia frente à tentativa de nos encaixar em lugares sociais pré-definidos e atravessados pela cultura do medo "do outro". Se "nada é mais importante do que essa nuança fugidia" (Tarde, I907 apud Themudo, 2002, p. 26), se trata, assim, de inventar uma concretude imagética e performática para essa nuança.

Jacques Ranciére descreve assim a seqüência política que se desenvolve a partir deste tipo de trabalho artístico: que um ator sem nome reclame para aparecer no cenário político, para ser admitido dentro dos cálculos e da distribuição dos bens comuns da sociedade. Segundo ele, aí está contida uma dimensão estética pois se trata de

55. Gabriel Tarde. Les lois sociales. Paris, Félix Alcan, 1907, p. 155. 
uma situação muito mais complexa do que a do partido clássico que indica a seus membros o que têm que fazer e como devem se colocar diante de um conflito político. Situação na qual as imagens utilizadas (Ranciére aqui se refere genericamente à produção de imagens alternativas àquelas veiculadas pelo pensamento hegemônico) surgem da colaboração (Holmes entrevistado por Expósito, 2006).

A partir de pensamentos e imagens dos grupos, podemos ver como acontece efetivamente $\mathrm{o}$ ato de restauração permanente desse conflito, constituindo um conjunto de evidências no campo do visível e do legível de como as instituiçôes normalizadoras são desafiadas e atravessadas por essa vontade de romper o ciclo de confinamento das subjetividades em lugares identitários.

Ainda no âmbito das metáforas do confinamento - que, ao mesmo tempo em que escancaram esse entendimento de si como alguém às vezes capaz e outras não de romper o lugar social que lhe é atribuído, escancaram também certas situações sociais simbólicas nas quais essa dicotomia está potencializada -, o GAC criou o trabalho "Blancos Móviles" (Alvos Móveis). "Blancos", no idioma espanhol, tem duplo significado: alvo e "em branco". Segundo o grupo, esse era um momento no qual as imagens até então utilizadas como formas de resistência simbólica já não eram capazes de reagir frente aos novos modos repressivos. 

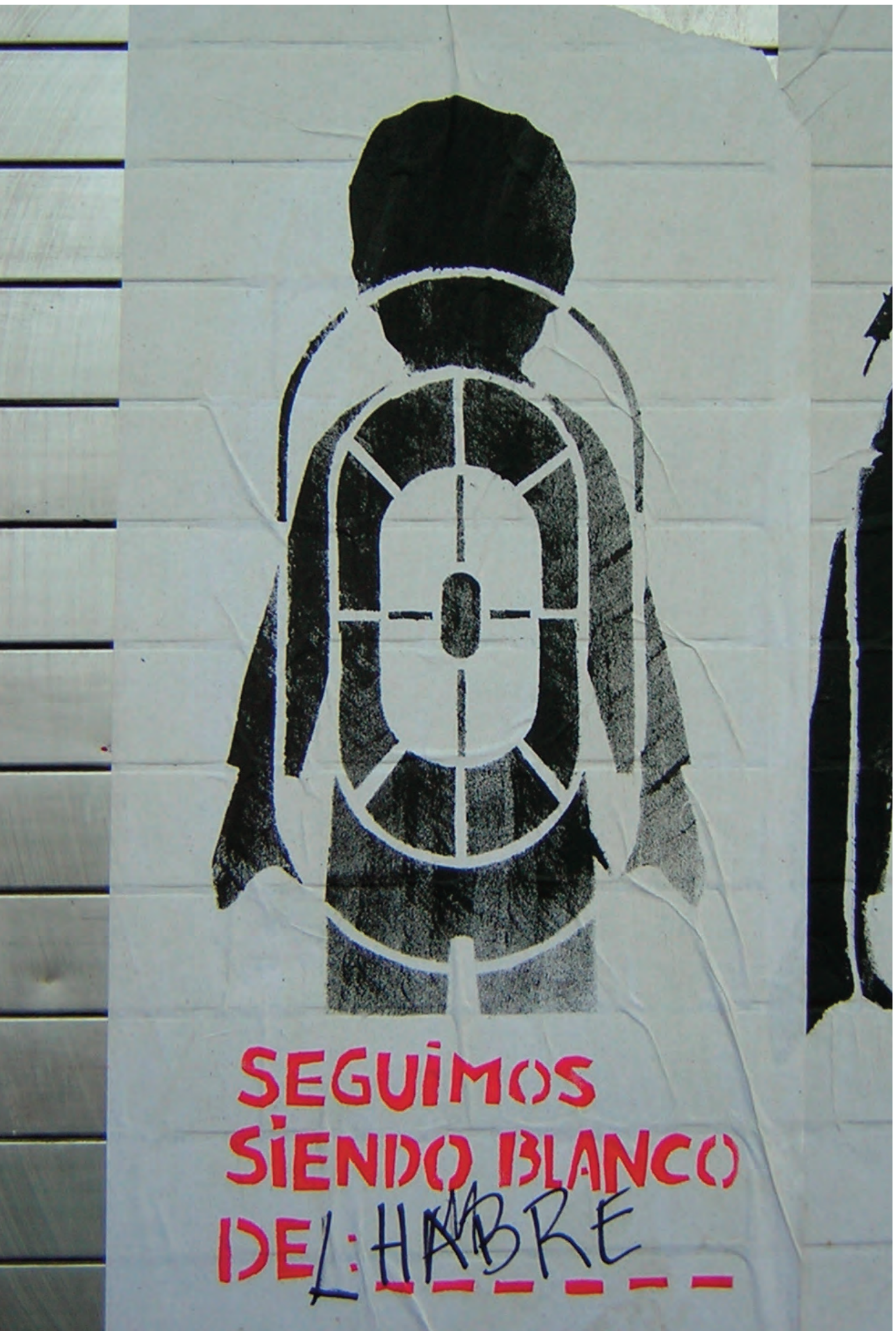

$\varnothing$
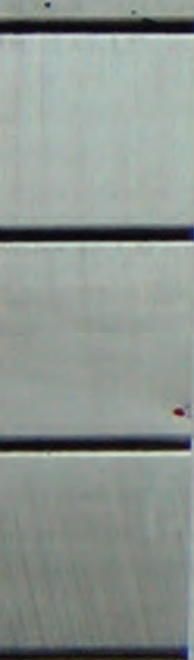


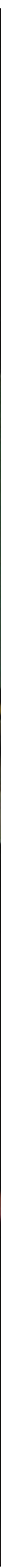




\section{JEGUIMOS
SIENDOD}

DE :LA BLANCO SEGUimos

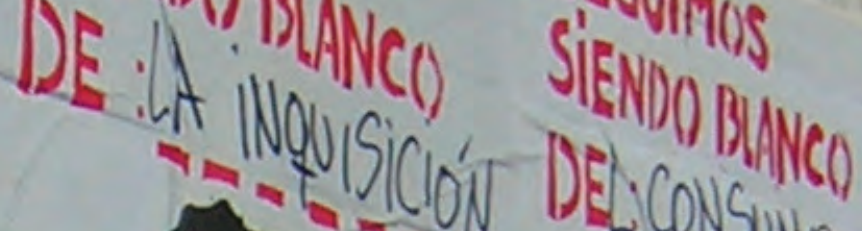

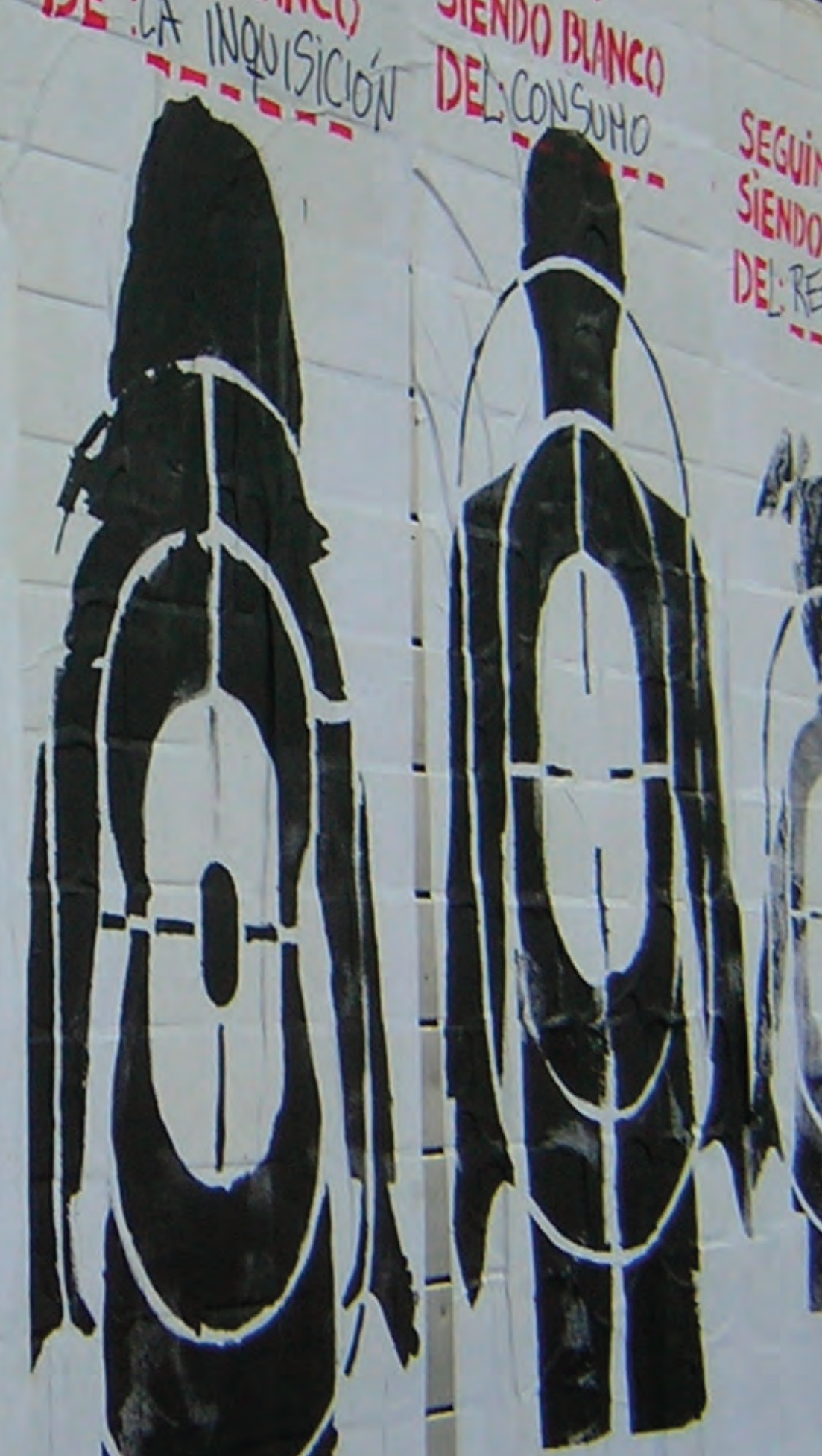

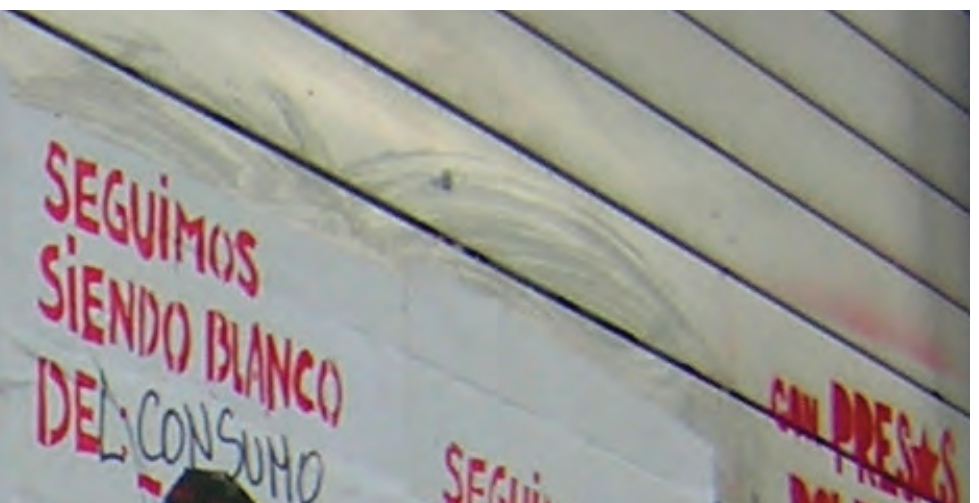

sifilinos

Monosy DE: RE ANCO $\rightarrow \rightarrow$ ropigin
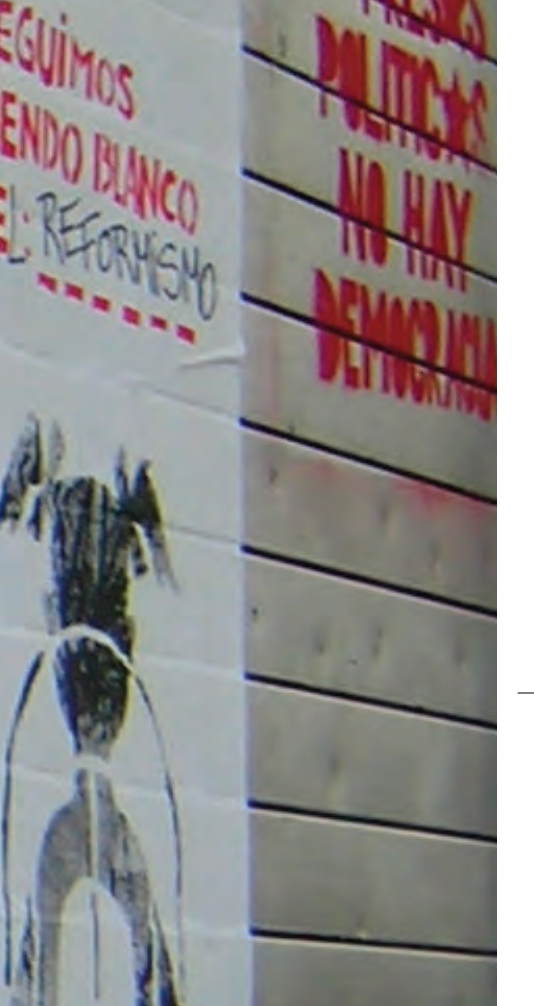
$y-1=\frac{1}{8}$

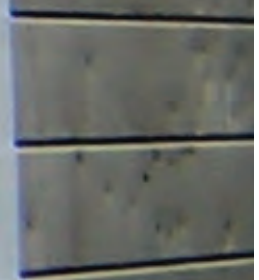

W xirg 12

\section{.}




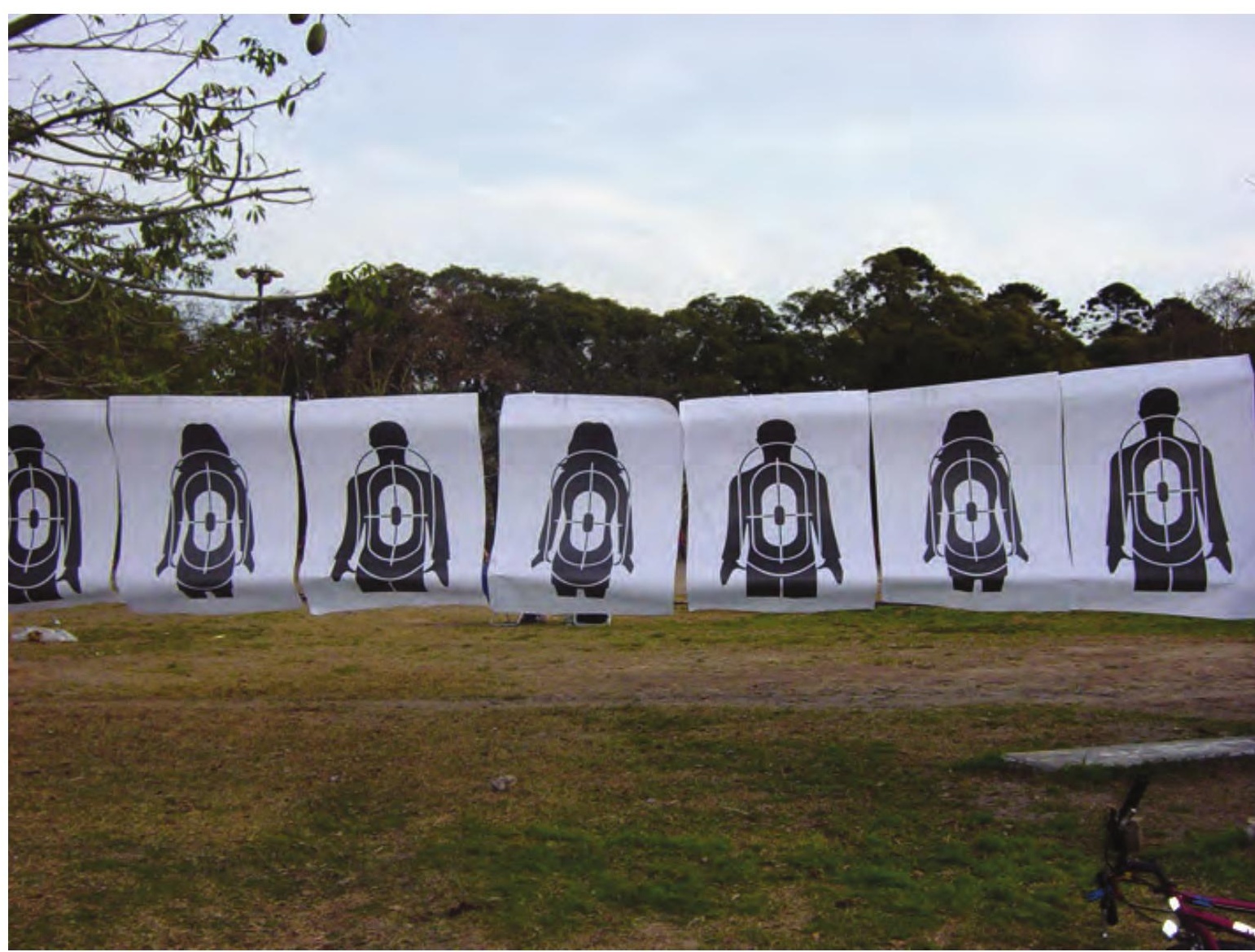

No trabalho Blancos Móviles, o GAC distribui um alvo para cada pessoa de um grupo,

comunidade, ou mesmo em uma ação organizada na rua, e pede para que interfiram nele. As soluções plásticas e imagéticas são muito diferentes em cada contexto onde são produzidas. 


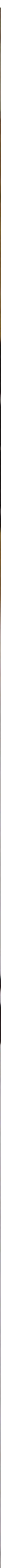




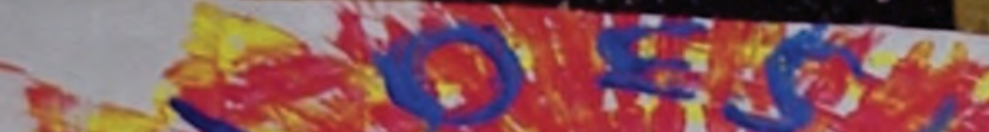

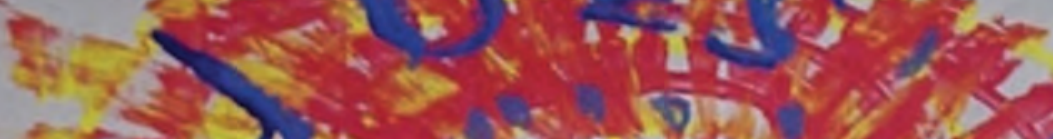

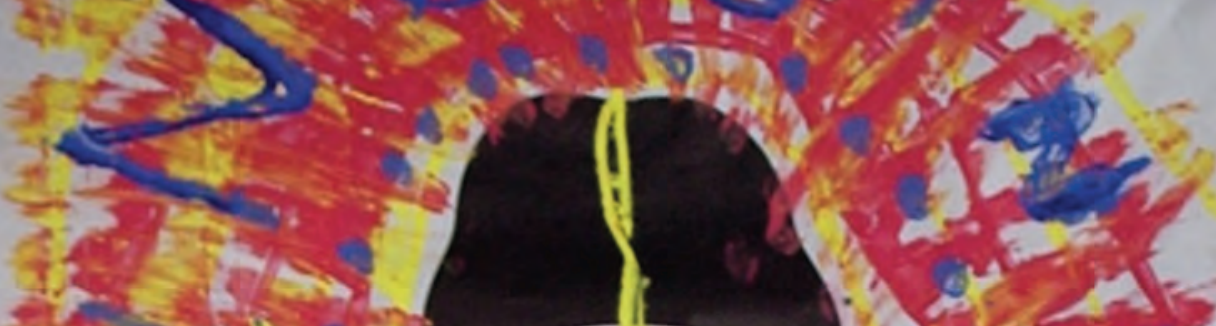

int 5 y

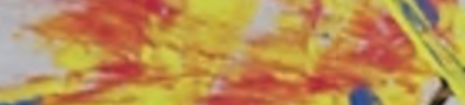

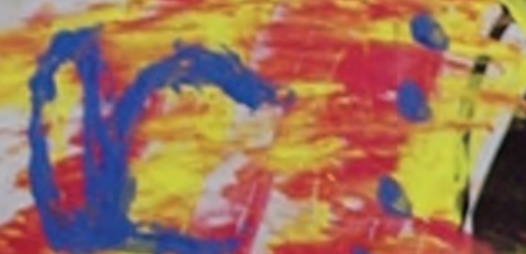

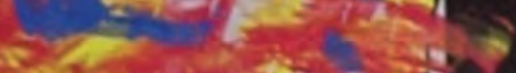

es $-x$

(1)

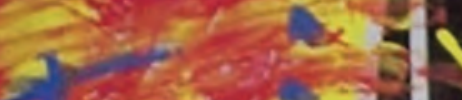
is a 3 3

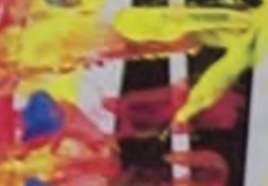

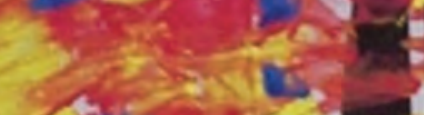

- 5 ?

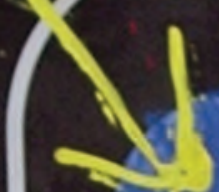

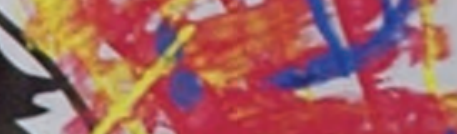
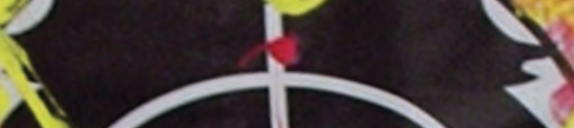

II

ater

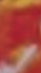

$9^{3 / 2}$

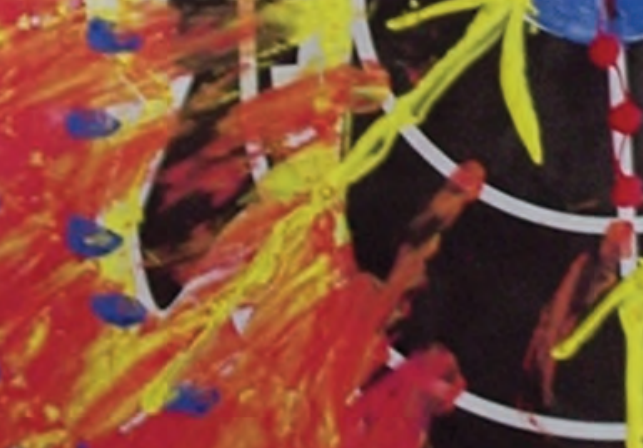

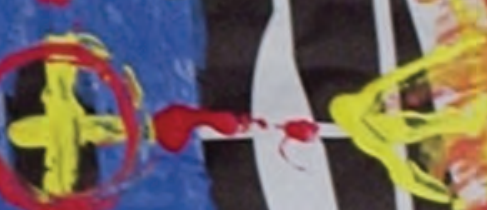

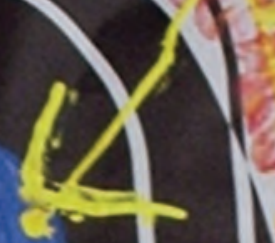

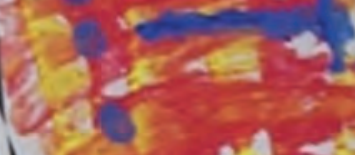

$40-212$

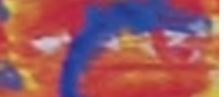

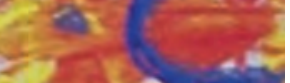
$(\sqrt{1}$

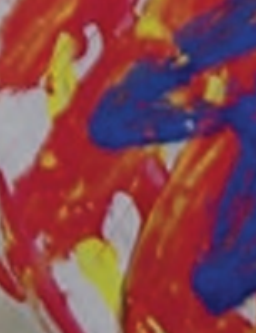

a)

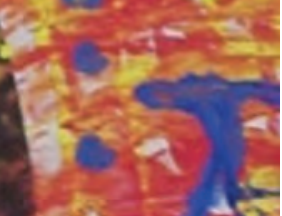


Lejos de estar a salvo seguimos siendo 'blancos'. Blancos Móviles. Muestran la manera en que se instala la perversa normalidad actual: convirtiéndonos en blancos de una ciudad que se vuelve fortaleza. Como en las viejas épocas feudales, el 'afuera' es tierra de nadie, y los espacios interiores prometen 'seguridad'. Los blancos móviles forman parte, a su vez, de una lucha por subvertir esa normalidad, recordando una véz mas que no es deseable, pero también mostrando hasta qué punto no es posible, porque está toda hecha de excepción, de brutalidad cotidiana y de salvaje precaridad. De allí que la silueta-blanco se tatúa en la piel de cualquiera, como carnet de identidad universal en la 'normalización'. Los blancos móviles expresan un nuevo temor. El que proviene de la relativa soledad que cada quien vive en la estabilización perversa, ese agujero negro en el que hemos caído. De ahí que estas figuras han sido tomadas con tanta fuerza en las distintas actividades. (GAC, 2009, p. 131-135)

Silluetas humanas: evocan el cuerpo como campo de batalla donde se juega el pasaje del terror a la capacidad de crear. Cuerpos en su doble dimensión de aquello que se tortura, humilla, viola, atemoriza, que se compra $y$ vende, que se anula; pero también materia viva capaz de activar, re-accionar, desear, componer, crecer, imaginar, resistir. Material privilegiado de la vocación modeladora y território ultimo de toda experimentación. El corpo es hoy escenario de lo político, donde la tristeza deviene alegría o bien acontece lo contrario: blanco de violencia y fuente de agresividad resistente. Objeto de los poderes y sujeto de las rebeliones; obsesión de la explotación y fuente de valor y cooperación; sustancia sensible a la mirada, a la palabra y término de sujeción o potenciación colectiva. (...) La 'movilidad' nos conectó con la circulación, indispensable para volver a activar las potencias de la imaginación colectiva" (GAC, 2009, p. 131-135). 


\section{CAPÍTULO II}

\section{A cidade em disputa}

A cidade pode ser julgada e entendida apenas em relação àquilo que eu, você, nós e (para que não nos esqueçamos) 'eles' desejamos. Se a cidade não se encontra alinhada a esses direitos, então ela precisa ser mudada. O direito à cidade 'não pode ser concebido como um simples direito de visita ou retorno às cidades tradicionais'. Ao contrário, 'ele pode apenas ser formulado como um renovado e transformado direito à vida urbana'. A liberdade da cidade é, portanto, muito mais que um direito de acesso àquilo que já existe: é o direito de mudar a cidade mais de acordo com o desejo de nossos coraçôes (David Harvey). 


\section{A cidade enquanto espaço referencial}

Para adentrar o problema de como cada coletivo, a partir de seus trabalhos artísticos, opera em diferentes escalas, ou seja, interagindo e intervindo em várias dimensões da cidade (compreendida enquanto espaço material e simbólico), foi fundamental, no meu percurso, entrar em contato com a discussão que está se dando no campo da sociologia e da antropologia, de como pensar a cidade hoje a partir da construção de novas categorias, novos objetos de pesquisa e novas perguntas, em relação aos quais os postos de observação são delineados como campos empíricos que levam em conta problemas situados.

As perguntas enquanto problemas situados ganham relevância na medida em que contribuem para o entendimento do contexto histórico atual, no qual a produção do espaço passa a representar um salto adiante das forças produtivas e uma modalidade nova de produção, que se estende ao espaço inteiro, do micro ao macro, em que a mercadoria se mundializa - "tudo se vende e se compra"-, em que, portanto, o próprio mundo é produto (Lefebvre, I98I).

O problema que se coloca então, é de como, na cidade, escala a partir da qual é possível compreender e analisar o surgimento e desenvolvimento de diversas soberanias (Appadurai, 1997), ocorre efetivamente essa disputa pela produção do espaço. Segundo Jorge Hajime Oseki:

Analisar e expor a produção do espaço (um conceito teórico e uma realidade prática) significa elegê-la como um momento da sociedade atual, isto é, como reveladora dessa mesma sociedade que permita apreendê-la como totalidade. [...] 'Não somente carac' terizar o espaço que vivemos em sua gênese, mas reencontrar 
paço social como referencial, um problema se coloca no que diz respeito às representações. Quando, no capitalismo, o espaço social absoluto torna-se abstrato, passando a se constituir como uma "abstração concreta" (com uma existência mental e uma realidade social concreta), o espaço físico se elabora numa dupla representação: a representação mental do espaço (espaço concebido) e o espaço das representaçôes (espaço da arte, dos simbolismos, da cosmologia).

Para Lefebvre, o problema das representaçóes como mediações que se tornam referências fundamentais para a atuação na sociedade contemporânea, não é o de sua existência, já que o autor considera que elas não só constituem a vida social como acabam se tornando socialmente concretas (pois tanto interpretam como interferem na prática). Mas sim, de que a distância irredutível entre o espaço mental e o espaço social seja dissimulada, quando o problema teórico, para o autor, é poder juntar o vivido, o percebido e o concebido, os espaços de representação e as representações do espaço, revelando as mediações.

Por isso, quando pensamos na disputa pela produção do espaço, estamos a todo momento nos referindo a dimensões materiais e imateriais e ao fato de que uma dimensão interfere na produção da outra. Levando em conta essas várias qualidades do espaço, Ananya Roy (2009) traz à tona a ideia de que é preciso haver também uma variação de perspectiva em relação à forma como os espaços sociais são produzidos, não sendo esta uma questão simplesmente de mudar a imagem ou a representação, mas de identificar alguns "campos problemáticos" que tornam-se estratégicos para a construção de um pensamento que dê conta da multiplicidade espacial. Segundo a autora, a informalidade do urbano é um destes campos estratégicos, pois circunscreve uma cartografia de fluxos, circulaçôes e mobilidades am- 
pliadas, na qual os espaços são mundializados "por baixo", evidenciando, na realidade, que a produção da cidade se dá eminentemente a partir da informalidade, não sendo este meramente um resultado do neoliberalismo.

Por sua vez, à medida em que novas mobilidades emergem e produzem outras fronteiras (materiais e imateriais), mercados, dispositivos políticos, a produção do social deixa de coincidir com a produção do Estado. A constituição de "soberanias sem território" (Appadurai, I997) evidencia que a cidade não pode mais ser apreendida como totalidade, já que populaçôes flutuantes redefinem e fazem transbordar do território específico as dinâmicas urbanas, seus simbolismos, suas cartografias. A mobilidade se torna, assim, um analisador das reconfigurações atuais dos mapas e territórios globais. É na cidade contemporânea como escala que se tornam visíveis, portanto, tanto os atravessamentos do local por processos transnacionais, gerando práticas e múltiplas disputas pela produção do espaço, quanto as novas formas de controle e gestão diferencial das mobilidades, das representaçóes e das populaçóes que surgem a partir disso.

Assim, se por um lado compreendermos o espaço e o tempo social como "absolutos", na medida em que não há mais como pensar de forma binária (dentro ou fora), estando tudo dentro do marco do "urbano" enquanto forma trans-histórica (Lefebvre, I98I); por outro, só é possível delimitar um campo problemático a partir do urbano na medida em que se leva em conta uma reconfiguração permanente da paisagem na qual novas cartografias surgem, sendo cada território físico atravessado por múltiplas condiçôes extraterritoriais.

Para Ananya Roy (2009), é necessário sair também da perspectiva binária na qual as cidades globais (cidades do norte) com- 
põem, em contraposição às cidades-favela (cidades do sul), os mapas de representação das cidades. De acordo com ela, a complexificação do pensamento e da ação em relação à cidade ocorre pela construção de um olhar ao mesmo tempo localizado e deslocado. O que significa, principalmente, uma ruptura com um discurso construído tendo o "centro" como referência e uma aposta em um olhar que, a partir das cidades do sul, se interroga sobre a possibilidade de que os problemas situados de tais localidades sejam considerados como campos estratégicos para a análise da complexa realidade na qual se encontram todos os lugares do mundo. A extraterritorialidade e a extraurbanidade passam a ser observadas como características de absolutamente todas as cidades contemporâneas.

Trazendo à tona três modos de produção do espaço emblemáticos de nossa atualidade (campos de refugiados, ocupaçôes e enclaves fechados) e com isso a discussão da regulação da terra ur bana como um jogo de escalas, Roy propóe a informalidade como o modo, por excelência, de mundialização das cidades atuais, assim como de subjetivação dos atores que as disputam. Hoje, portanto, a constituição da subjetividade e o embate do sujeito com a cidade, na disputa pelo próprio estatuto, significado e prática da cidadania, estariam acontecendo de forma situacional, local, contextual. O que não significa que nas situações de informalidade não estejam presentes os atravessamentos e redes globais; pelo contrário, muitas vezes é justamente nesses espaços que comunidades inteiras são introduzidas às redes, fluxos simbólicos e discussões políticas e estéticas contemporâneas.

Partindo da realidade americana e das questôes migratórias ali presentes, Nina Glick Schiller e Peggy Levitt (2004) mostram como as práticas migrantes, a circulação de pessoas e bens cria insti- 
tuições, mercados e microeconomias urbanas, e não apenas "memórias" e "representaçôes". É esta trama institucional, segundo as autoras, que evidencia que os migrantes são participantes ativos do mundo urbano, portanto, produtores de espaço e operadores de escala; que ativam redes sociais, que levam e trazem múltiplas conexões e que possuem um caráter multisituado. O que colabora para a superação da lente étnica a partir da qual eles são sempre vistos como "desenraizados", como evidência do inacabamento de um suposto “projeto nacional”.

A noção de território circulatório e de um "saber circulatório" traz importantes contribuiçôes para esta discussão, ao tratar a própria circulação como produtora de lugar, de espaço social, de territorialidade, de afetos, vínculos, saberes, de uma historicidade, formas de regulação, agenciamentos políticos e organizações e, portanto, também, de formas de apropriação das riquezas materiais e imateriais aí produzidas pelo Estado e pelo capital (Tarrius, 2002). Não à toa, como uma das principais agendas de pesquisa atuais, estão as questóes políticas envolvidas nas migraçóes transnacionais e a questão de como pensar teoricamente identidades e soberanias pósnacionais e extraterritoriais em movimento, processos de subjetivação que se fazem de forma rizomática.

Neste sentido, hoje se torna fundamental repensar o próprio conceito de sociedade - já que as relaçôes sociais se fazem em rede, conexão e movimento -, sem, no entanto, abandonar os jogos de poder que compóem o campo social e os Estados nacionais operantes (Levitt e Schiller, 2004). Schiller e Levitt buscam construir uma teoria que parte de uma prática etnográfica para formular evidências de como os jogos de poder, que são jogos situados de escalas, acontecem, na tentativa também de "espacializar o Estado" (Ferguson e 
Gupta, 2002) para subverter as imagens verticalizadas e de abrangência do mesmo (que seriam decorrentes da naturalização da ideia binária de Estado como contraponto à sociedade civil) e vê-lo operando como prática situada.

É a escala da cidade que, ao tornar inteligíveis as tensões em jogo, possibilita, por um lado, não ficar cativo da noção de EstadoNação como definidor das identidades e, por outro, não cair em uma noção líquida das mobilidades, como se o poder soberano do Estado, que detém o poder de suspender a norma, já não fosse uma das soberanias que disputam a produção do espaço.

O capitalismo contemporâneo se constitui assim em uma intensa relação entre fluxos de riquezas, pessoas, símbolos e redes de coerção e coesão, através de mecanismos de extração e expropriação que evidenciam que os espaços não são lisos, mas constituídos por fronteiras materiais e imateriais, nas quais as dobras entre o legal e o ilegal, o lícito e o ilícito, o formal e o informal se evidenciam. O espaço urbano, por sua vez, pode ser definido como o lugar no qual esses campos de força e disputa pela reinvenção, aplicação, suspensão da norma e da lei se efetivam, na medida em que os fluxos extraterritoriais de símbolos, pessoas e mercadorias acontecem.

Segundo o sociólogo brasileiro Michel Misse (2002), a questão do tráfico de drogas passa a ser uma questão relevante na medida em que a economia da droga ativa um circuito de mercados informais e mobiliza uma rede de atividades ilícitas justamente em um momento no qual a flexibilidade do capital está instaurada. Ao colocar a economia da droga como um mercado que se organiza articulado com outros mercados, sendo a relação entre os mercados necessária para o pleno funcionamento do capitalismo na contemporaneidade, Misse está questionando, sobretudo, a abordagem dis- 
ciplinar que faz do crime uma questão da criminologia quando, pelo contrário, assim como as fronteiras entre o legal e o ilegal, o significado de crime (que muda em cada contexto sendo, portanto, segundo o autor, uma categoria nativa e não sociológica) está, a todo momento, sendo negociado.

Essa abordagem implode com a ideia de mercado informal e ilegal como um setor à parte e coloca de novo em xeque a figura do Estado como detentor do poder de decidir o que é legal ou ilegal, lícito ou ilícito. Por sua vez, a porosidade entre legal e ilegal não faz com que a questão da lei e da norma seja indiferente, mas evidencia o mecanismo de "gestão diferencial dos ilegalismos" (Foucault, I997), que consiste em fazer com que as leis operem não para efetivamente punir, mas para poder controlar. A configuração deste campo de forças no qual a fronteira do que é legal e ilegal é constantemente negociada como mercadoria política, coloca em jogo o próprio sentido simbólico da lei e da norma (Misse, 2002).

Veena Das e Deborah Poole (2004) sugerem que uma "antropologia das margens" ou das situaçôes-limite colaboraria na verificação de como a indeterminação entre legal e ilegal, regra e exceção é produzida pelo próprio Estado. A margem, para elas, apresenta uma importância analítica ao tornar inteligíveis os modos como o Estado se constitui no mundo contemporâneo. O que está em jogo aí, é o próprio poder soberano do Estado, que se funda em sua capacidade de suspender a lei.

As configurações pós-nacionais não significariam, neste sentido, a ausência política do Estado, mas novas formas de agenciamento e operação do mesmo. As autoras fazem uma provocação ao questionar se, ao invés da ausência do Estado ou da presença de um "Estado fraco", não seriam as situações extremas de violência, justa- 
mente aquelas nas quais se dá a sua fundação. Somente assim, sugerem, seria possível entender o poder do Estado na atualidade, como ele de fato está operando.

A partir da percepção da margem como espaço de disputa do significado da norma, fica evidente que o Estado não está acabado, mas está sempre sendo refundado. As “margens”, portanto, não são territoriais, não são as periferias, mas sim "lugares situados" e se trata, assim, de entender os processos que produzem tais situações. 


\section{Espacialização da norma e da invenção}

Sendo fundamental, nos trabalhos dos coletivos aqui analisados, a constituição do social no engendramento mesmo da constituição da subjetividade em sua diferenciação, é na cidade como escala - como situação transversal e como campo estratégico no qual as problemáticas do contemporâneo operam -, onde encontram o espaço afetivo e efetivo da enunciação. Nesse sentido, a decodificação das normas que delimitam os poderes hegemônicos (em sua maior ou menor visibilidade e legibilidade), assim como o enfrentamento das mesmas e a invenção de outras normas e códigos (informais e locais), são feitos a partir de uma perspectiva espacial. É assim que a "legalidade” de certas normas instituídas é desafiada: a partir da invenção de acontecimentos urbanos enquanto fatos empíricos que partem da informalidade, podendo adquirir legitimidade ${ }^{57}$.

Aqui se faz presente a questão institucional - em termos ampliados, não somente entendida enquanto Estado, mas também “instituição linguística”, códigos e discursos hegemônicos, códigos urbanos, etc. - levando-se em conta que, como diz Paolo Virno, a "instituição", enquanto termo e conceito, não pertence somente ao "adversário", mas é decisiva para a política da multidão (2006, p. I2) $)^{58}$. Virno fala aqui da relativização da noção de soberania dos estados centrais que, apesar de se reproduzir está, segundo ele, em crise profunda, o que leva à instauração de um "estado de exceção permanente [que] atenua - até quase desaparecer por completo - a diferença entre 'questôes de direito' e 'questôes de fato"' (id. ibid., p. ro). A isto associa-se o que ele chama de "instituições da multidão" por sua forma de funcionamento, na qual as "normas passam a ser encaradas enquanto fatos empíricos, assim como os fatos empíricos podem

57. Entende-se esta legitimidade conquistada no nível simbólico, como uma imagem e um pensamento que passam a circular, contribuindo para a construção social de outras formas de pensar e agir. Às vezes, essa legitimidade simbólica do acontecimento pode ser tão poderosa, que interfere diretamente no poder normativo, como aconteceu na Argentina, com ações simbólicas que clamavam por "justiça social". Conforme ação do GAC analisada a seguir. 
adquirir poder normativo" (id. ibid., p. IO-II). Assim, se muitas vezes encontramos nas ações artísticas analisadas o questionamento em relação aos códigos e normas direcionado à maneira como a memória social é espacializada, isso ocorre na medida em que a própria situação de exceção cria uma indefinição que torna possível a subversão criativa. Uma prática muito comum entre os coletivos é a de intervir em placas de trânsito, monumentos, outdoors, bandeiras, mantendo a forma original, porém mudando o seu sentido de modo a criar uma situação crítica.

\author{
Quantas vezes designamos, ao longo de nossas vidas, \\ uma rua que leva o nome de um genocida? Quantas \\ vezes nomeamos uma marca de uma multinacional \\ que escraviza e mata? Estão tão internalizados estes \\ nomes e produtos em nossa cotidianidade, que é uma \\ utopia pensar simplesmente que poderiamos nos des-
}

58. A noção de "multidão" e de uma forma de fazer política associada a ela, é muito utilizada por autores contemporâneos que constroem teorias relacionadas às formas atuais do capitalismo e de resistência a ele. Segundo Virno, "Estoy verdaderamente convencido de que la multitud es el modo de ser colectivo caracterizado por el hecho de que todos los requisitos naturales de nuestra espécie adquieren una inmediata importancia política. [...] Marx definía la fuerza de trabajo como 'el conjunto de las capacidades psíquicas y físicas de un cuerpo humano'. Pues bien, esta definición se vuelve completamente verdadera sólo en los últimos treinta años. En efecto, sólo recientemente las competencias cognitivas y linguísticas han sido puestas a trabajar" (Virno, 2006, p. 6-7). Michael Hardt e Antonio Negri definem assim essa noção em seu livro Multidão: “ [...] alternativa viva que se vem constituindo dentro do Império. Pode-se dizer, simplificando muito, que a globalização tem duas faces. Numa delas, o Império dissemina em caráter global sua rede de hierarquias e divisões que mantém a ordem através de novos mecanismos de controle e permanente conflito. A globalização, contudo, também é a criação de novos circuitos de cooperação e colaboração que se alargam pelas nações e continentes, facultando uma quantidade infinita de encontros. Esta segunda face da globalização não quer dizer que todos no mundo se tornem iguais; o que ela proporciona é a possibilidade de que, mesmo nos mantendo diferentes, descubramos os pontos comuns que permitam que nos comuniquemos uns com os outros para que possamos agir conjuntamente. Também a multidão pode ser encarada como uma rede: uma rede aberta e em expansão na qual todas as diferenças podem ser expressas livres e igualitariamente, uma rede que proporciona os meios da convergência para que possamos trabalhar e viver em comum. [...] Na multidão, as diferenças sociais mantém-se diferentes, a multidão é multicolorida. Desse modo, o desafio apresentado pelo conceito de multidão consiste em fazer com que uma multiplicidade social seja capaz de se comunicar e agir em comum, ao mesmo tempo em que se mantém internamente diferente. [...] Na medida em que a multidão não é uma identidade (como o povo) nem é uniforme (como as massas), suas diferenças internas devem descobrir o comum que lhe permite comunicar-se e agir em conjunto. $O$ comum que compartilhamos, na realidade, é menos descoberto do que produzido" (2005, p. 9-14). 
fazer deles, já que em parte eles nos construiram. Porém, ao reconhecê-los e reconbecer as politicas que os tramam, podemos desconstruir seus nomes e imagens. Esta é a luta política do simbólico, que não apenas nomeia os esquecidos e vítimas da violência do poder, como nos restitui, a nós mesmos como aos demais, o poder de construção de uma identidade autônoma em relação à que nos é imposta, que encontra a liberdade no processo vivencial das utopias (GAC, 2009, p. 304). 

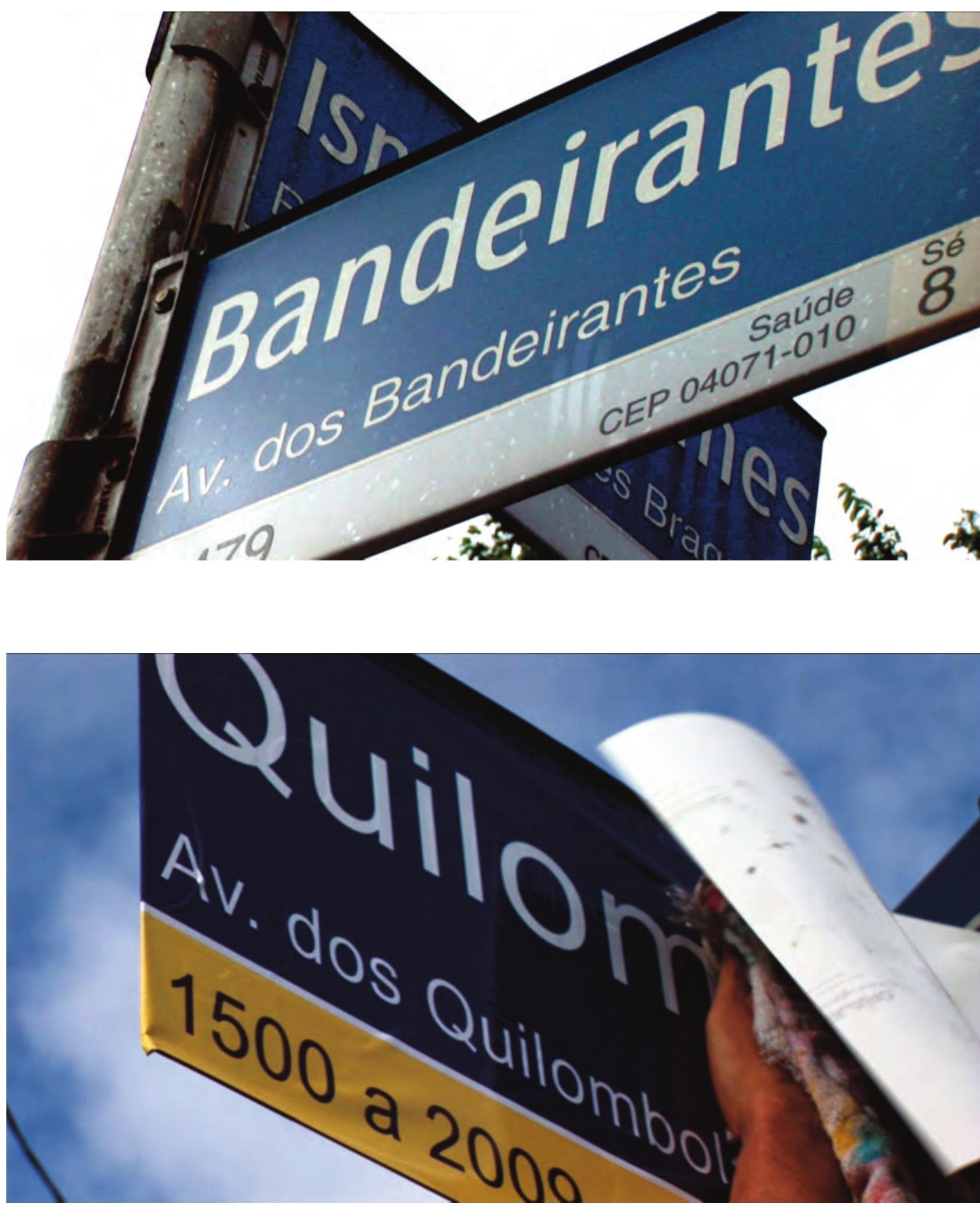

Placa feita pelo PI mudando o nome da Av. Bandeirantes para Av. dos Quilombolas, São Paulo, 2008. 


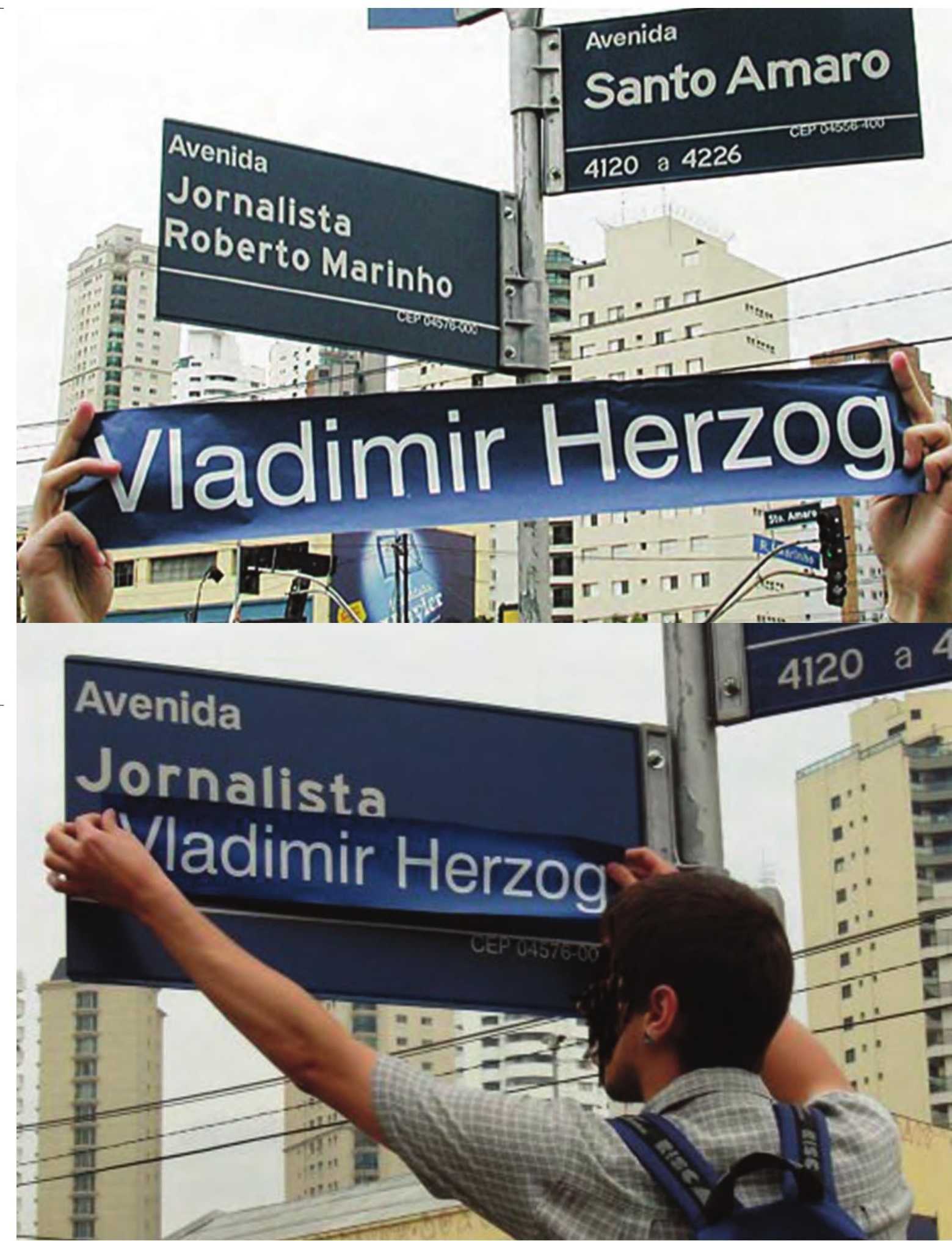

Trabalhos que usam códigos oficiais, modificando-os. Respectivamente: Centro de Mídia Independente, Jerusa Messina e PI. 
Essa tentativa constante de partir da materialidade urbana, está muito relacionada a uma necessidade radical de ir, aos poucos, entendendo que a dimensáo histórica imaterial que nos constitui, está de fato materializada no espaço e, portanto, podemos agir frente a isso. O que leva a experienciar o espaço não a partir de percepções abstratas, mas de um esforço cotidiano de decodificação simbólica, o que é uma marca da inteligência coletiva que vai constituindo a política da multidão. Faz parte desse esforço um processo de revisão permanente de si mesmo e da sociedade para a produçáo de representaçôes que efetivamente subvertam a comodidade da memória, tornando-a viva no sentido de acionar a reflexão sobre o presente.

Podemos ver isso claramente em diversas ações do GAC, que tem como um dos seus principais focos de trabalho a atualização da memória da última ditadura militar argentina. Junto a outros grupos e movimentos sociais, como Madres de la Plaza de Mayo ${ }^{59}$, H.I.J.O.S ${ }^{60}$ e $\mathrm{MTD}^{61}$, desde o final da década de 1990 cria formas de dar visibilidade e legibilidade ao fato de que as forças repressivas continuam ativas e encontram-se inseridas no jogo de poder atual, e não, como estamos acostumados a pensar, em um lugar abstrato, distante no tempo e no espaço, nos filmes e livros de história.

\section{El peso de lo visual es estratégico en la construcción de identidad y memoria generacional. Después de tanta práctica y tanta experimentación es impor- tante preguntarse quéforma de construcción genera}

59. Mães dos desaparecidos políticos da última ditadura militar argentina que desde $\mathbf{1 9 7 0}$ lutam por justiça.

60. Hijos e Hijas por la Identidad y la Justicia contra el Olvido y el Silencio. Segundo definição presente em seu site: "H.I.J.O.S é um agrupamento independente e horizontal de direitos humanos, formado, em princípio, por filhos de desaparecidos, ex-detentos e exilados da última ditadura militar Argentina. H.I.J.O.S. luta pela justiça e punição aos repressores da ditadura militar, impulsiona investigações, juízos e ações contra os repressores. Junto à luta de outras organizações, H.I.J.O.S inscreveu conceitos como os de justiça social, memória ativa e continuidade histórica. Cria, em meados dos anos 90 , a prática do escrache (da palavra escrachar)". Fonte: http://www.hijos.org.ar, acessado em março de 2012.

61. Movimento dos Trabalhadores Desocupados da Argentina, também conhecido como piqueteros por terem tornado freqüente a prática do piquete (barricadas em estradas e ruas), através da qual reivindicavam por melhores condições de vida. 
otro tipo de comunicación y de visibilidad, en contrapunto a aquello construido oficialmente. Tratando de contestar esta pregunta, me parece necesario revisar las construcciones de la memoria a lo largo del tiempo y detectar cuáles logran conectar con la potencia (visual, simbólica, política, enunciativa), frente a la impronta estatal, fijadora, muchas veces improductiva. Para encontrar formas que tengan la fuerza de renovar las imágenes, de registrar los cambios y de producir nuevas temporalidades, se precisa también una nueva investigación (GAC, 2009, p. ro5).

\section{[...]}

Desde su formacion en 1977, las Madres de la Plaza de Mayo, a traves de sus cuerpos, hicieron visibles a los desaparecidos. Estar en la Plaza, ocupar ese espacio y circular por el, corporizó el sentido de lucha contra la impunidade en la peor época de la dictadura. Todos los jueves, trascendiendo el repertorio cultural e iconográfíco conocido, ellas estuvieron presentes con su empeño en la Plaza de Mayo. Lo hicieron a través de sus cuerpos en movimiento, como modo de contrarrestar el estado de sitio y la imposibilidad de reunión. Ya en democracia, prolongarony resignificaron su accionar. Los pañuelos blancos destacan que la acción de las Madres es altamente simbólica y el uso del espacio público conscientemente estratégico. Las Madres actuaron contra el sistema represivo de representación que tan 


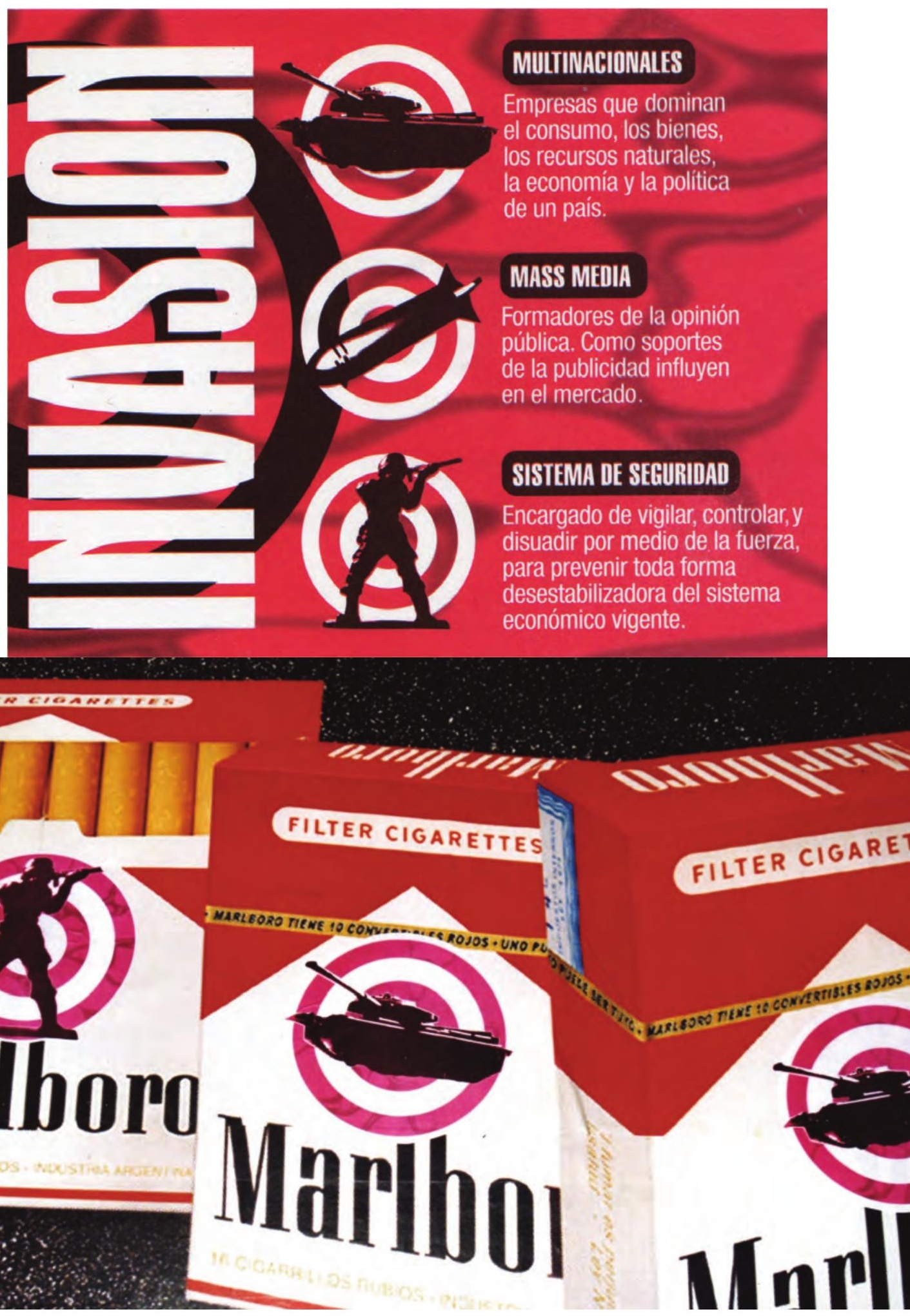


 \\ PROJETO JO O8B: Layout 1 Y}

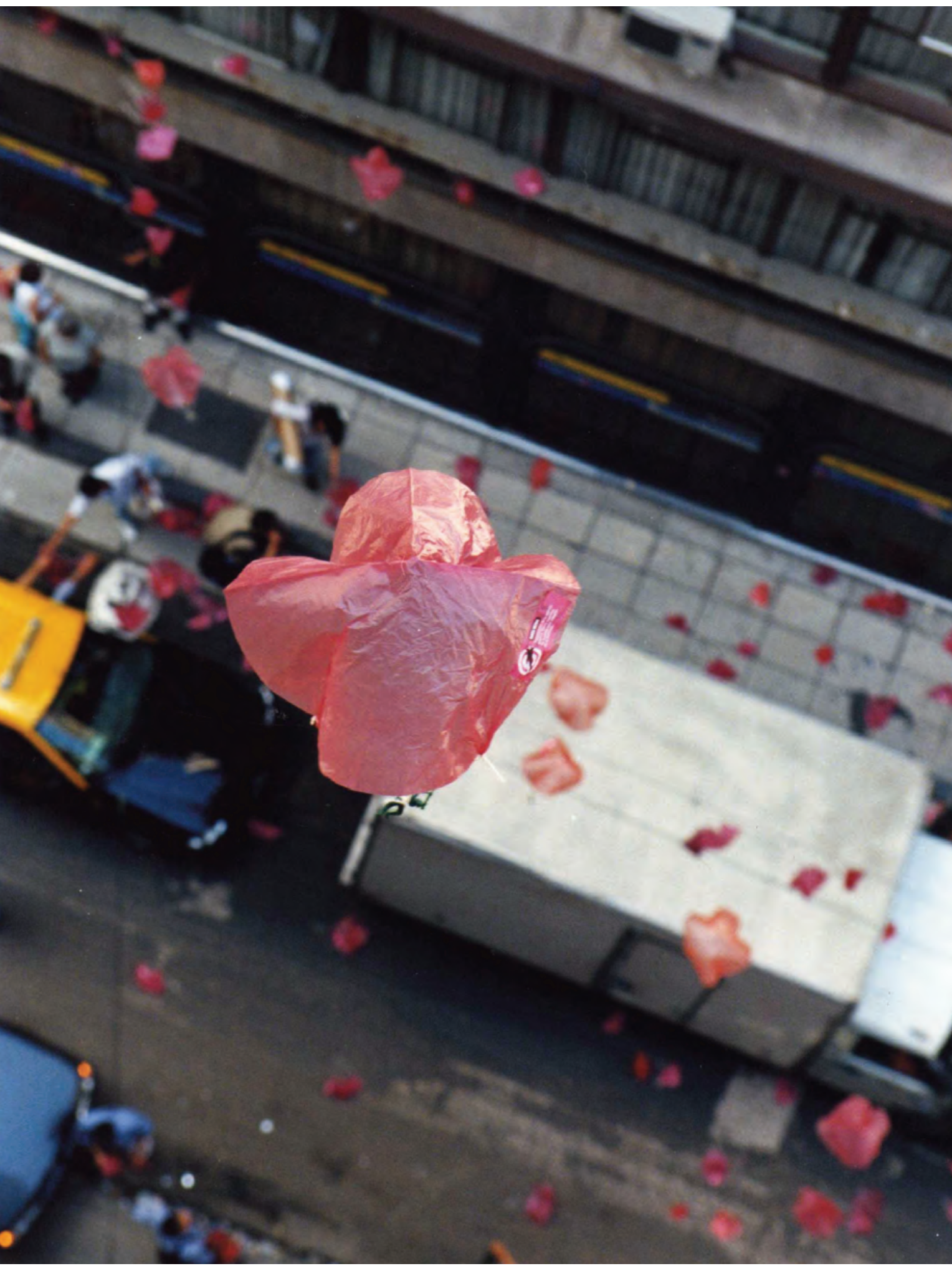


PROJETO JO 08B:Layout 1 7/25/12 11:35 AM page 174

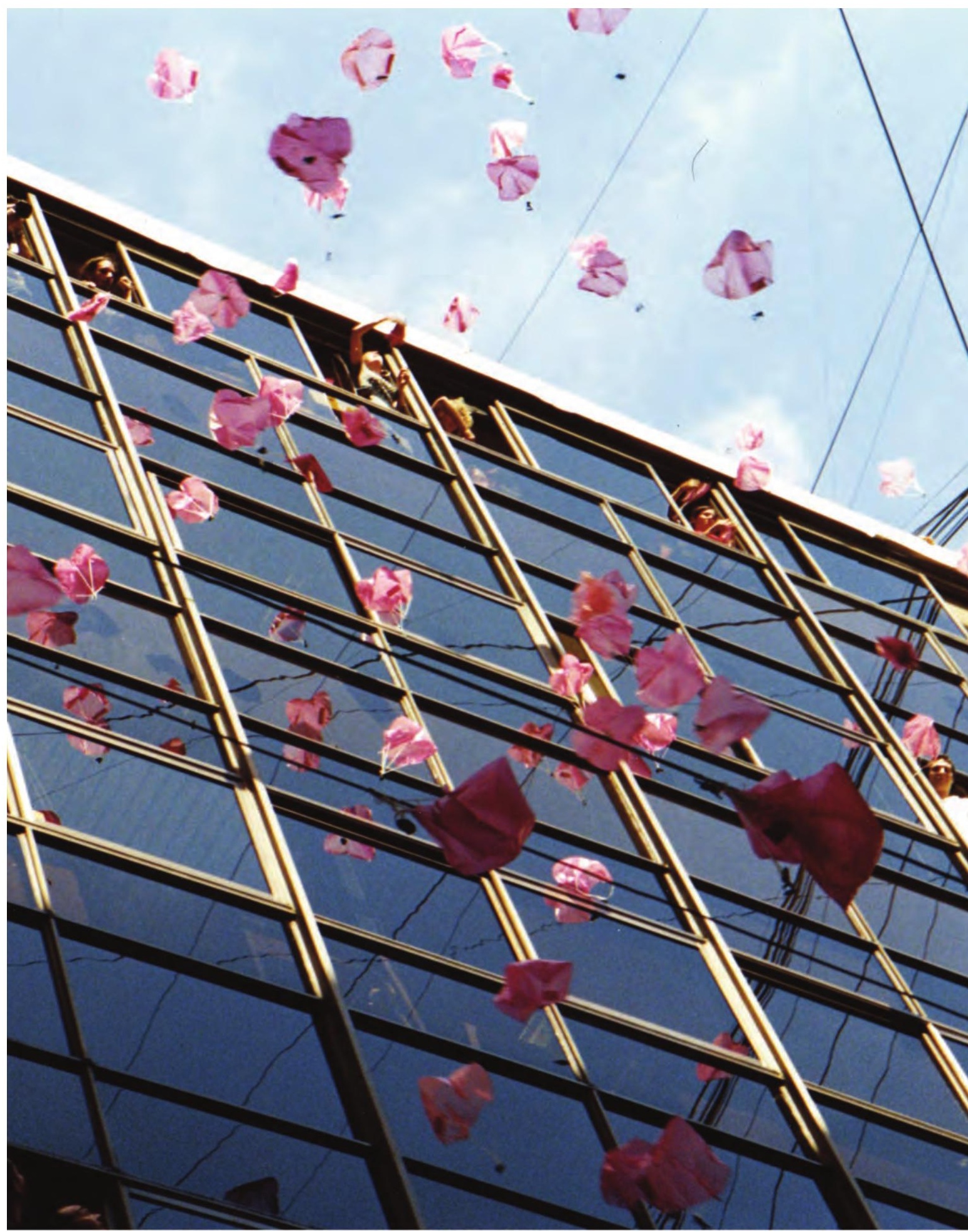

Lanzamiento de diez mil paracaidistas en miniatura desde un edificio del microcentro. Durante la semana previa a la acción se intervino todo el territorio circundante con calcomanías de íconos militares: el tanque, simbolizando el poder de las multinacionales; el misil, equivalente a la propaganda mediática; el soldado, que aludía a las fuerzas represivas que necesita el sistema para mantener el orden neoliberal. La acción coincidió con el comienzo de la rebelión popular de los días 19 y 20 de diciembre de 2001 (GAC, 2009, p. 323). 


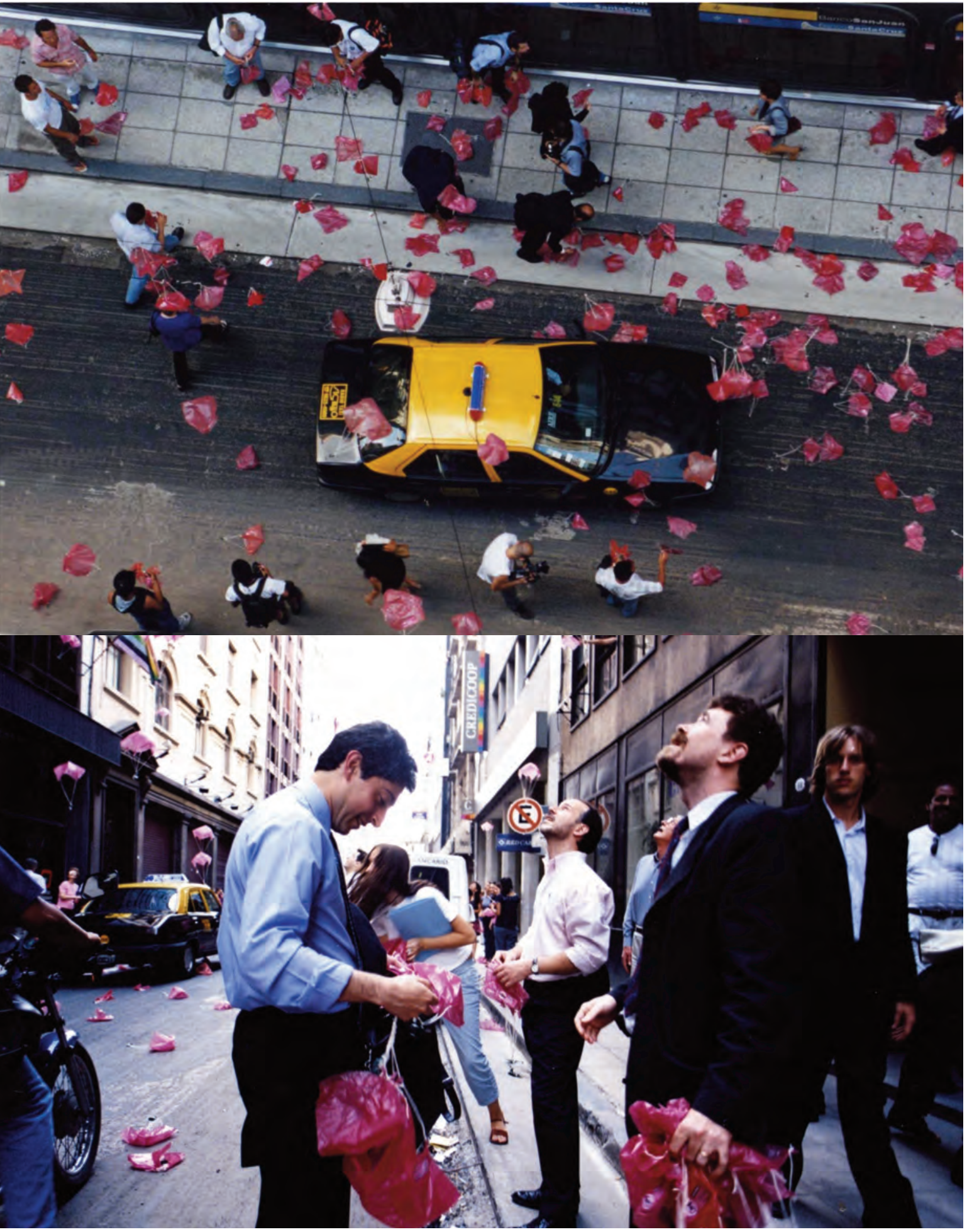


efectivamente ha limitado las posibilidades de visibilidady expresión (GAC, 2009, p. 99).

Todos esses grupos, em colaboração, desenvolveram e aplicaram o conceito de "justiça social" no enfrentamento da impunidade dos responsáveis pelo terrorismo de Estado ocorrido na última ditadura militar argentina, nomeados de "genocidas" pelo movimento de direitos humanos daquele país ${ }^{62}$. Para enfrentar os "genocidas", abordam o problema da impunidade a partir de sua delimitação enquanto um "problema situado". Neste sentido, tornam inteligível o fato de que torturadores, torturados, filhos e famílias de desaparecidos, vivem todos na mesma cidade, circulam pelos mesmos espaços, podendo ser até vizinhos.

\begin{abstract}
En ese tiempo [quando iniciaram o trabalho com os movimentos de direitos humanos, no fim da década de I990] sentiamos la necesidad de marcar y señalizar los espacios de la ciudad que habian funcionado como CCD (Centro Clandestino de Detención), pensando en la no visibilidad de esos lugaresy en las formas en que eran o no registrados por las personas que transitaban por alli o por sus cercanias. Nos propusimos trabajar sobre los espacios físicos del terrorismo de estado y sobre su invisibilidad con el objetivo de develar (escrachar) a los sujetos partícipes de la dictadura (GAC, 2009, p. 80).
\end{abstract}

62. O Movimento de Direitos Humanos argentino denominou os torturadores como "genocidas" na década de 80 , partindo do pressuposto de que eles exterminaram toda uma geração, se apropriando também de filhos de desaparecidos, no intuito de exterminar a possibilidade de difusão de ideias revolucionárias de uma geração para outra. 
Nesse sentido, uma das ações recorrentes desse movimento, é pesquisar onde os torturadores vivem hoje, nas diferentes cidades da Argentina. Assim como no Brasil, militares ativos durante a ditadura militar continuam tendo altos cargos, seja no governo, seja fora dele - muitos são donos de empresas de segurança privada.

A partir desse banco de dados, o movimento criou o que denominaram de escrache. Este se inicia com um processo de conscientização da comunidade do entorno onde vive um "genocida", de que é vizinha deste torturador, contando para todos o que ele fez, onde atuava, quem matou, etc. No início, isso se dava de forma bastante silenciosa, já que era um processo perigoso e que ainda não tinha o apoio da sociedade e do próprio Estado. Aos poucos, foi se tornando uma prática legitimada socialmente ${ }^{63}$.

La palavra escrache significa en lunfardo 64 'sacar a la luz lo que está oculto', 'develar lo que el poder esconde': que la sociedad convive con asesinos, torturadores y apropiadores de bebés, que basta aquel momento permanecian en un cómodo anonimato (GAC, 2009, p. 57).

\section{[Na] prática do escracbe [...] os percursos e espaços de vida dos repressores da ditadura são demarcados na cidade e evidenciados através de experiências co- letivas, politicas, estéticas e de divulgação nos bair-}

63. Na era Kirchner, com os integrantes do movimento sendo absorvidos pelo Estado, passou-se a discutir a questão da cooptação, dos prós e contras dessa entrada em peso de todo um ideário, antes reprimido, no centro das discussões e ações estatais. Se, por um lado, a ideia de "justiça social" foi ouvida e o movimento simbólico conseguiu intervir na própria consolidação dos processos criminais de ex-torturadores; por outro, a força de inovação do movimento de direitos humanos argentino está vivendo um "impasse". Diversas vezes nos últimos anos, quando estive na Argentina (em 2007, 2008, 2009 e 2010), ouvi pessoas de diferentes grupos falando sobre uma certa despotencialização daquela energia sentida no início desse processo de experimentação cultural e social.

64. 0 lunfardo pode ser considerado como o idioma do tango argentino. Fonte: Wikipédia, acessada em março de 2012. 

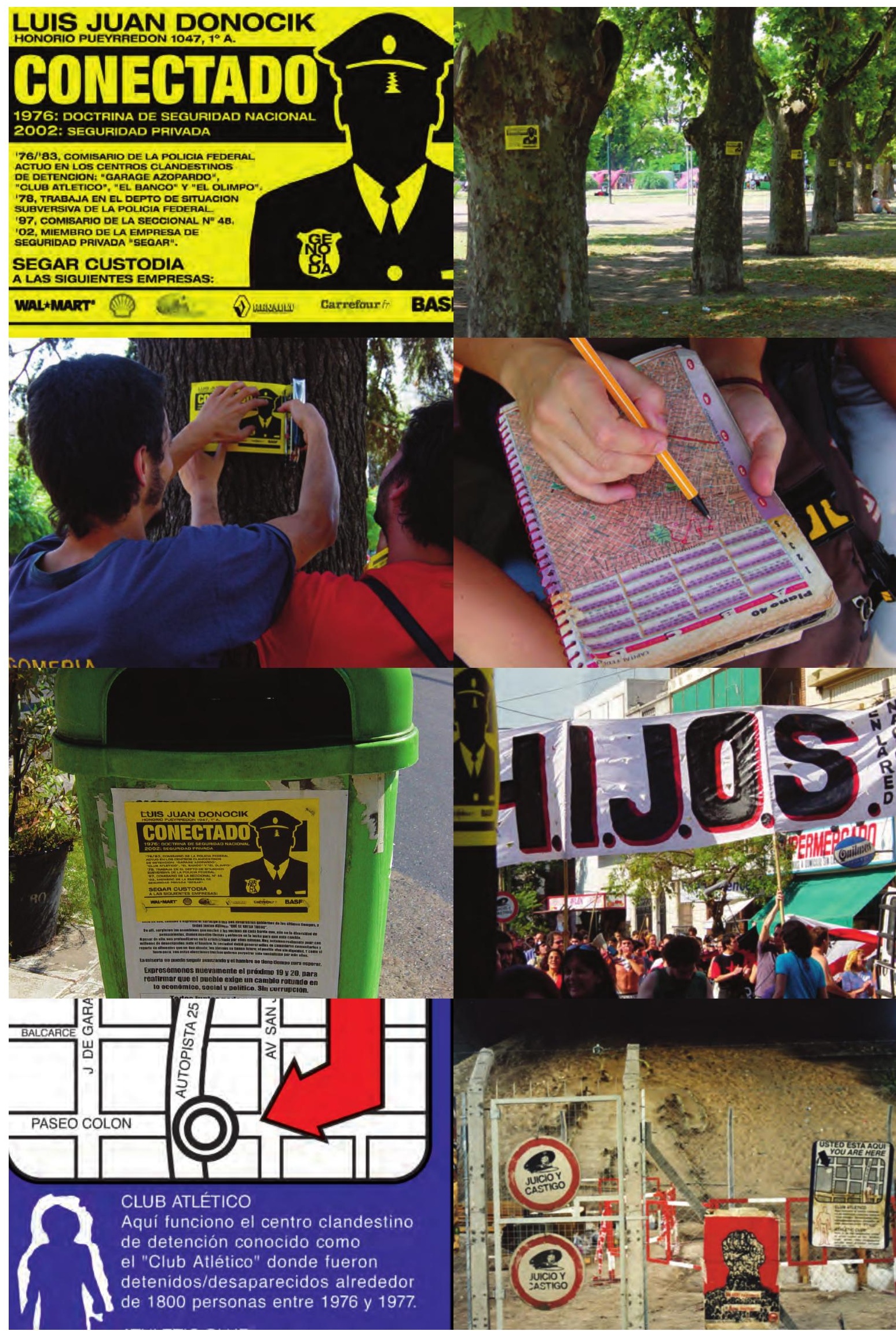


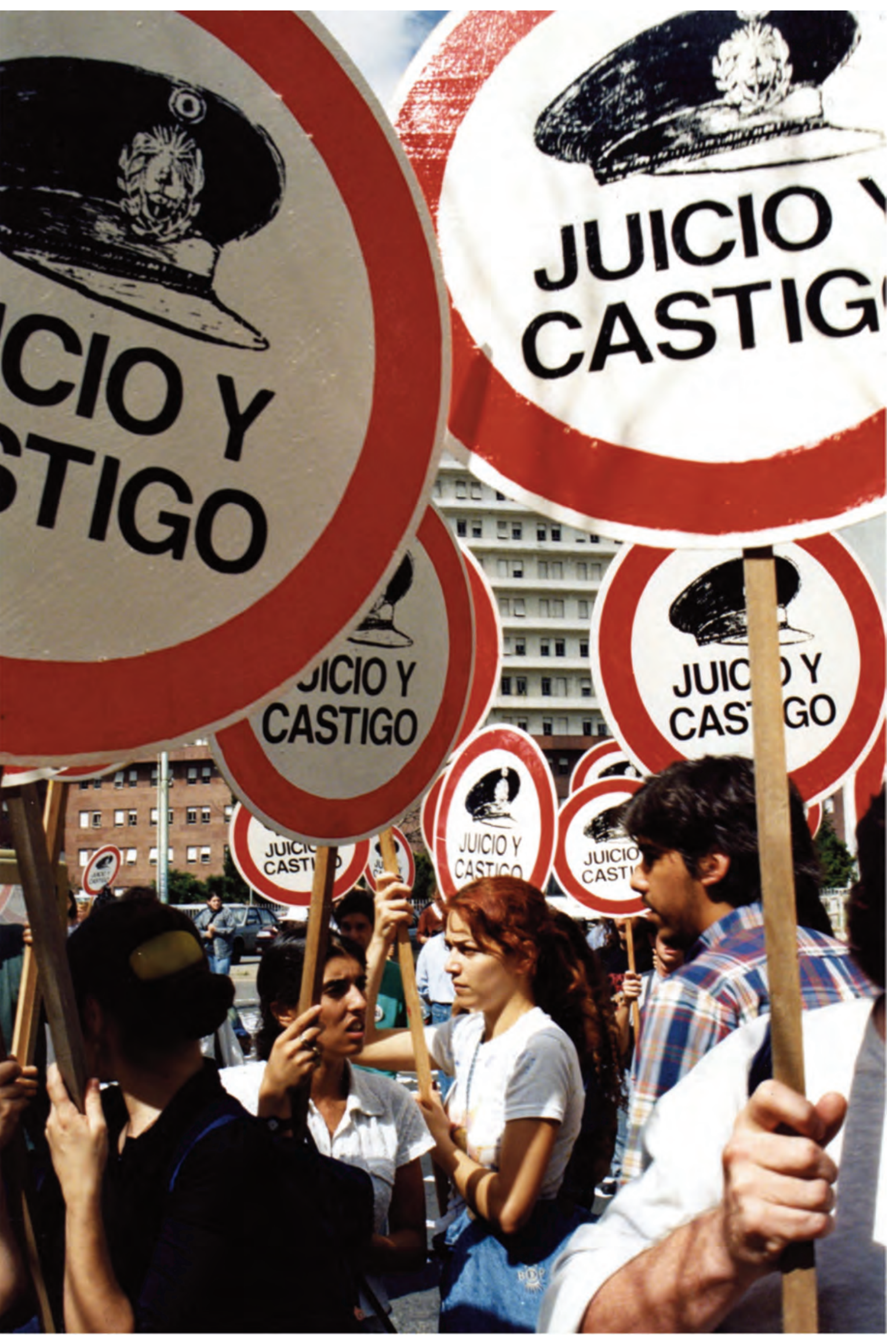


PROJETO JO 08B:Layout 1 7/25/12 11:35 AM page 180
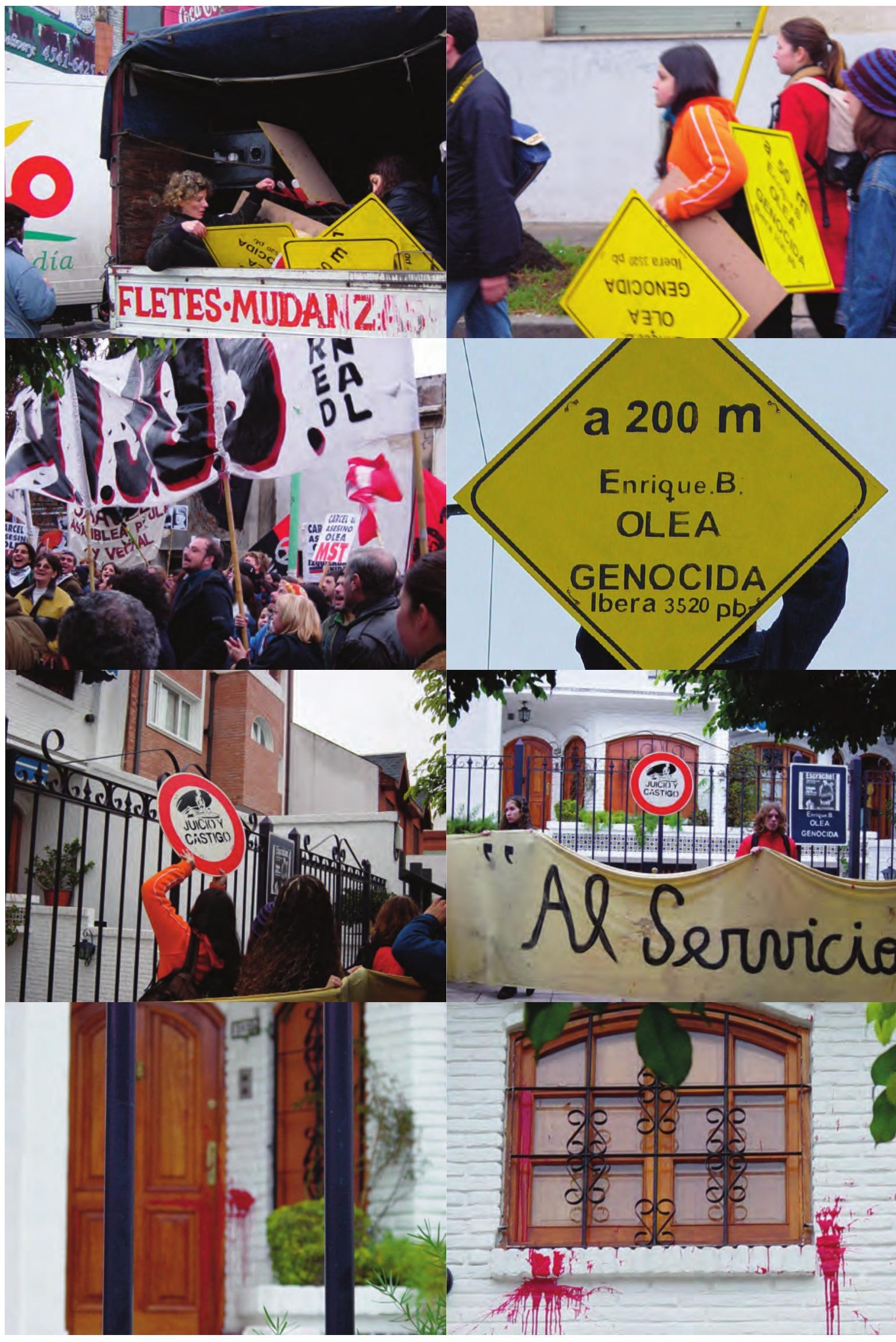


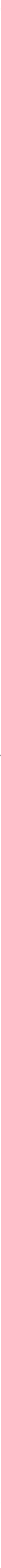


PROJETO JO 08B:Layout 1 7/25/12 11:35 AM page 182
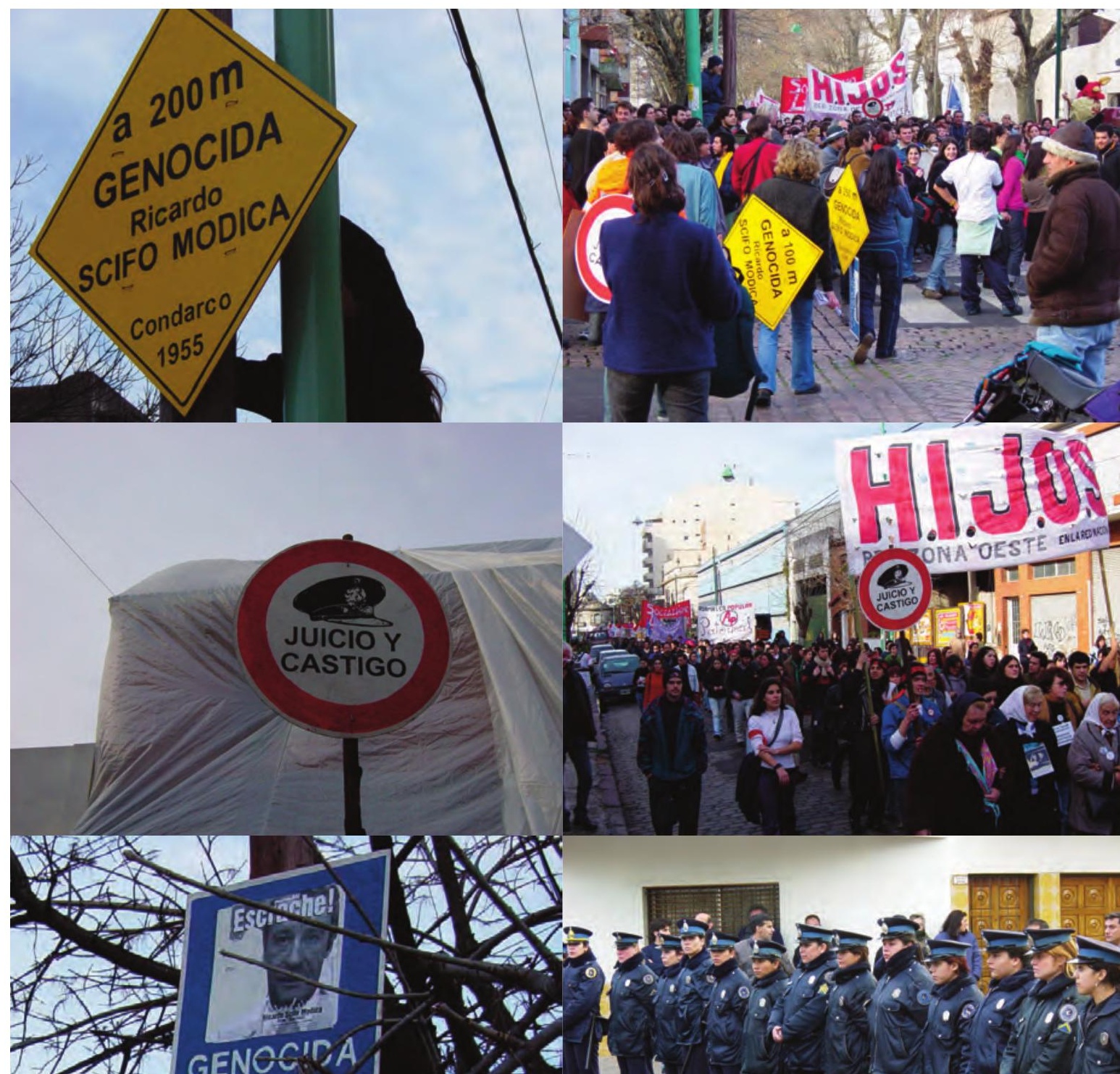

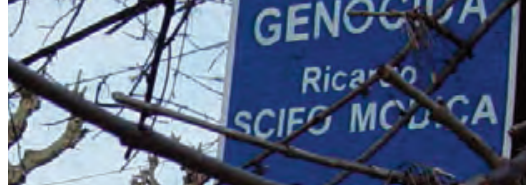

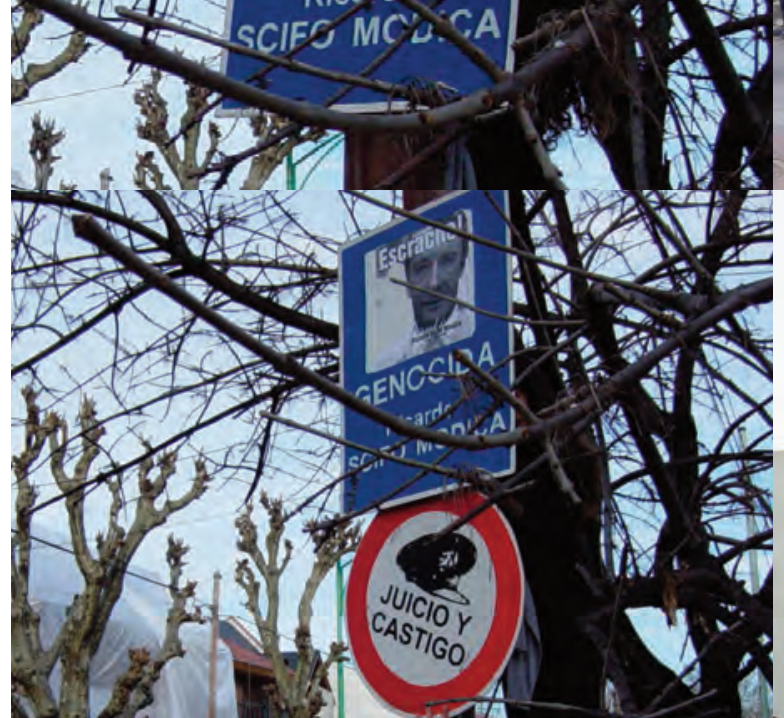
(11 III
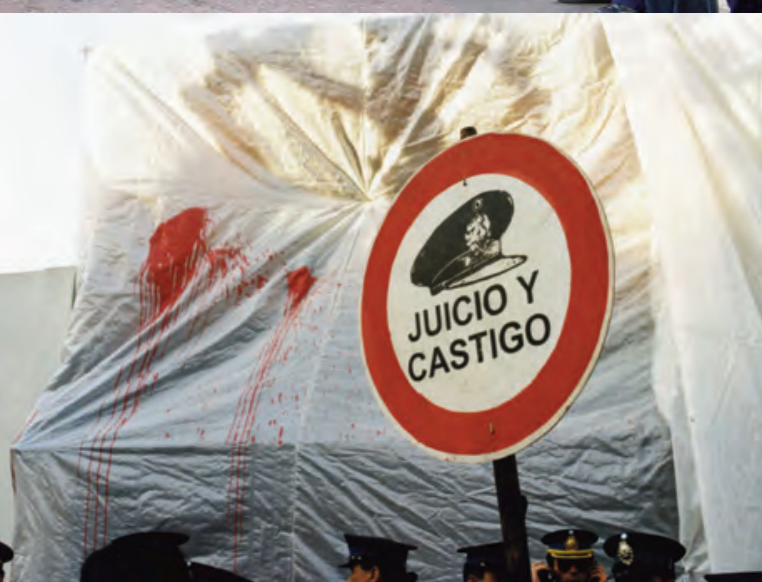


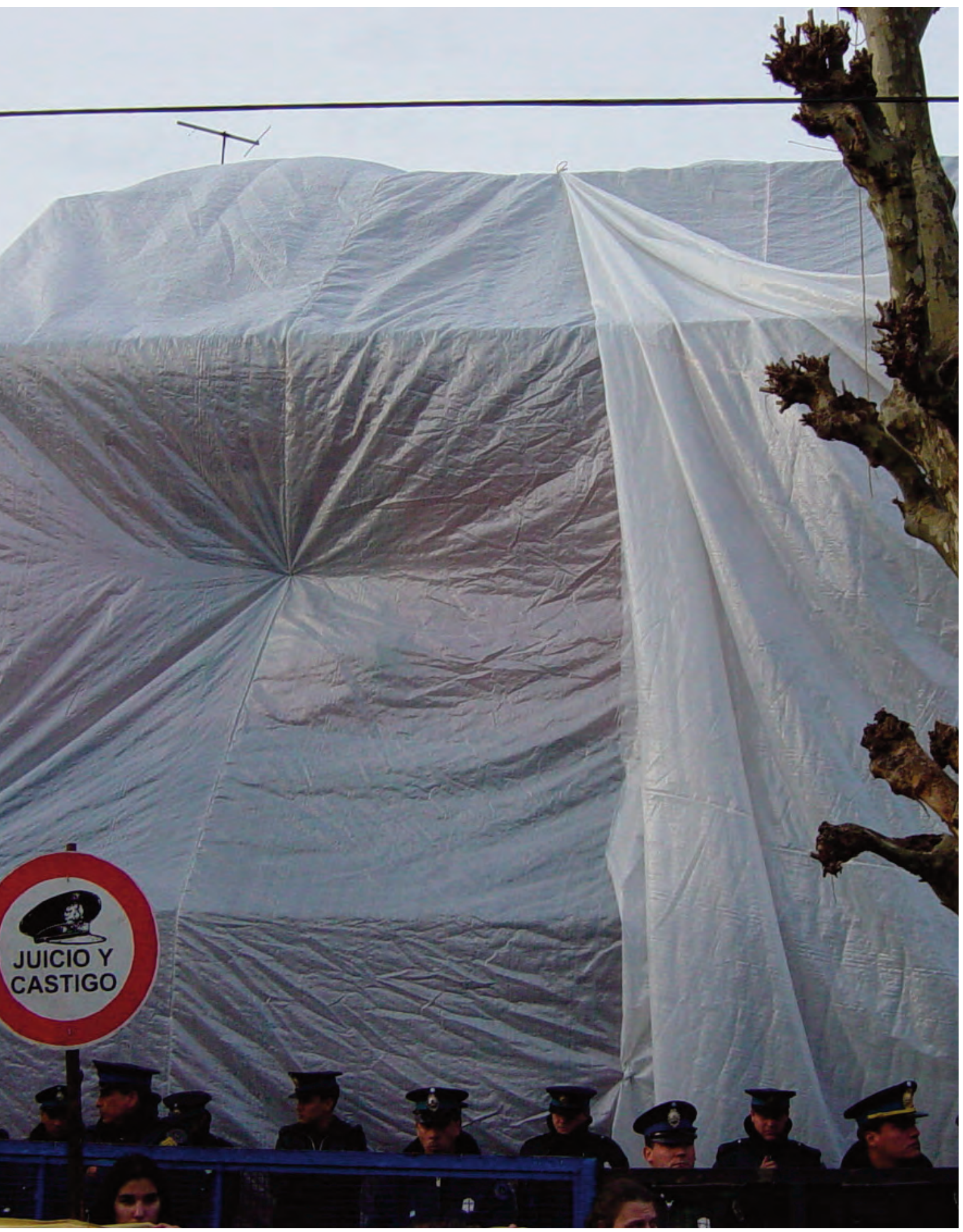

Imagens dos escraches. Buenos Aires, Argentina. 2002-2007. 


\section{ros. Essa prática abriu um espaço plural e constante de atuação, possibilitando, a partir de uma nova forma de participação política, uma transformação profunda do imaginário social e fez avançar a política de direitos humanos na Argentina (H.I.J.O.S, trecho presente em seu site).}

Na data marcada, uma marcha é feita de um ponto combinado até a casa do torturador apontado daquela vez. Os integrantes destas ações falam que o escrache é uma "festa". Mas o que, de fato, centenas de pessoas "celebram" em frente à casa de um torturador? Como entender esta noção de "festa" diante de fato simbólico tão claramente baseado no enfrentamento?

Muitas linguagens somam-se para dar forma ao escrache enquanto acontecimento urbano: tambores, teatro, discursos históricos sobre o genocida escrachado daquela vez, rádio aberta de comunicação com o entorno do escrache, jornal, pinturas, cartazes, lambelambe, intervençôes urbanas, trabalhos educativos prévios de contato e diálogo com os vizinhos do torturador, cartografias. Essa multiplicidade de linguagens em colaboração gera uma "vitalidade do comum" (Situaciones, 2009 b, p. 337) e produz uma "comunidade de sentimentos" (Ferrari, 2010) ${ }^{65}$. Assim, o escrache coloca à prova, a partir de estratégias que dão vazão ao lugar da corporeidade na política (o que também potencializa o lugar da festa nessa situação) ${ }^{66}$, a possibilidade de rearticulação coletiva depois das fissuras abertas pela ditadura militar. Podemos ver esse desejo operando na seguinte afir mação do GAC:

65. Segundo a antropóloga Florencia Ferrari, tratando sobre os ciganos Calon do Estado de São Paulo: "As festas mostram que há um repertório comum entre todos, permitindo que a música seja parte de uma 'comunidade de sentimento'. Música e dança permitem fluxos de emoção que passam e ultrapassam os corpos, criando relações" (Ferrari, 2010, p. 213). 0 uso da música, da dança, dos tambores nos escraches, pode ser entendido da mesma forma, apesar de estarmos falando aqui de uma ação profundamente politizada (o que não é necessariamente o caso em todas as situações de festas populares). 


\section{[...] en el mejor de todos los casos, si todos los mili-} tares fuesen presos, el proceso de escrache seguiria porque su principal objetivo es reflexionar sobre las alteraciones sociales y el quiebre en la red de relaciones intersubjetivas producidas por el genocidio para también trabajar desde allí los conflictos sociales presentes (GAC, 2009, p. 62).

O que está em jogo na dimensão festiva e múltipla dos $e^{-}$ craches, que tem a escala da cidade como suporte, é justamente a potência gerada nessa construção colaborativa de uma forma de justiça: ao redor da casa do torturador, simbolicamente o prendem, subvertendo o lugar histórico de cada um (opressores X oprimidos, torturador $\mathrm{X}$ torturados, trauma $\mathrm{X}$ comodidade, etc.). Aqui, cabe comentar os aspectos dessa outra prática de justiça:

[...] o sea, la justicia no depende de una instituición que la encarne, sino de la acción que la produce. [...] El escrache, entonces, es una situación que propone y implementa una práctica alternativa. O sea, que contiene indicios de una nueva sociedad [...]. El escrache es una referencia visible de una nueva practica de transformación (Colectivo Situaciones, 2002).

Quando falo sobre a escala da cidade como suporte, estou propositalmente diferenciando esta noção, da noção de cidade como

66. Diz o GAC sobre a crise Argentina de 2001: "Hay momentos en que resulta fundamental sentir el propio cuerpo, pues aun cuando éste parece anulado, replegado, en verdad nunca se apaga por completo. Es en la corporalidad común donde se aloja la memoria inmediata de aquella situación de potencia social, experimentada por todos en diciembre de 2001. No es simplemente una ilusión, sin algo verificable en los hechos, aunque aparezca fugaz y difusamente, bajo la forma de respuestas espontáneas de la gente, estallidos que arrasan comisarías, incendian los transportes precarios, una fuerza arrolladora que olvida el miedo y desarma el discurso de la seguridad" (GAC, 2009, p. 287). Acredito que essa afirmação, mesmo focada nos acontecimentos de 2001, possa ser ampliada para pensar os escraches, assim como outras formas políticas criadas pela geração da qual fazem parte os coletivos aqui apresentados. 
suporte, no sentido que esta última assume tradicionalmente na história da arte, já que não me refiro a um espaço sobre o qual um “autor" realiza a sua "obra”, mas sim a um espaço como matéria viva constituída de múltiplas temporalidades, escalas de vida e de poder, convertido em plataforma (ou seja, em tempo-espaço do encontro dessa multiplicidade), para a criação de uma imagem de justiça. É importante pontuar a questão da materialidade do espaço urbano como elemento significativo desse tipo de manifestação artística, já que os processos de trabalho aqui analisados não "instalam" objetos de arte na cidade. Mais do que "utilizar o espaço" ou entender a sua materialidade apenas como meio físico, essas manifestações são operadoras de escala, na medida em que instituem situações e acontecimentos inesperados a partir daquilo que está aparentemente "dado". Assim, criam uma atualização do que está sendo dito ao subverter espaços formalizados do dizer.

É essa plataforma material-simbólica como um tempo-espaço de confluências, que permite a emergência de um "instante de perigo". O instante de perigo, segundo Walter Benjamin, pode ser compreendido como um impasse, no qual ocorre uma imobilização temporal que permite enxergar o que nos antecede e, simultaneamente, exercer uma redenção ${ }^{67}$ no que está por vir, fundindo-se, no agora vivenciado, passado, presente e futuro (Benjamin, I985, p. 234-235).

\section{El escrache que surge de H.I.F.O.S también trabaja dentro del orden de lo simbólico. Tanto Madres como H.I.F.O.S usan el espacio público denunciando y marcando las casas de los represores y sus cómplices. Su acción consiste en señalar y narrar los lazos que conectan la impunidad de bace treinta años con la}

67. A noção de redenção em Benjamin se relaciona à capacidade humana de libertar a história do pensamento linear, único e homogêneo que nos faz acreditar em um futuro histórico teleológico, ou seja, já dado. Assim, ao olhar para "aquilo que poderia ter sido", para os aspectos residuais oprimidos e não inscritos historicamente diante do poder hegemônico, poderíamos, segundo o autor, mudar o curso da história, anunciar novos possíveis. 
situación actual. Madres e H.I.Y.O.S, aunque con diferencias en cuento a sus estrategias, no aceptan el espacio público como zona de prohibición. Por el contrario, lo usan como lugar sobre el cual desplegar una cartografía de la acción. Un modo de la acción que hace uso de la memoria como función del presente, $y$ no solo del pasado (GAC, 2009, p. 99-10o).

Portanto, a "representação direta da justiça", que subverte a casa do torturador em símbolo, o corpo de uma geração em símbolo, a ocupação em símbolo, não constitui uma imagem esvaziada de experiência, pelo contrário, o próprio escrache é mídia portadora de vínculo, carne e devir. Considero, portanto, que no escrache, o que celebram é essa descoberta de que performatizar a dor coletivamente, produzindo um espaço compartilhado a partir dela, leva a sair da passividade, redimindo-a.

Los comienzos de los escraches están muy ligados a la irrupción social y mediática de la agrupacion H.I.F.O.S e impactan fuertemente en la opinión pública. Desde sus inícios rompen con varias formas 'tradicionales' de hacer política. Por su apelación a la potencia de la creatividad, de la alegria y de lo festivo como herramientas de lucha. [...] Si bien es muy importante escrachar al genocida, de alguna manera también es una excusa para llegar al barrio y abordar las problemáticas del presente. Desde este lugar hemos trabajado junto a vecinas/os de algún barrio problemas de vivienda, de violencia policial, de cor- 
mupción en los tribunales, de las difícultades para enfrentar los miedos a bablar del pasado, generando espacios de encuentro y reflexión que relacionen las continuidades del genocidio y nuevas problemáticas (GAC, 2009, p. 6r).

O GAC, como grupo artístico, sempre atuou produzindo um repertório de imagens que tornasse possível a circulação da potência desse movimento ${ }^{68}$, desenvolvendo, portanto, um saber circulatório dos símbolos produzidos em situação, na medida em que formalizava aquilo que poderia ficar apenas em uma escala local.

Dentro del grupo siempre fue importante la circulación del registro, no sólo para comunicar y compartir las experiencias con otros colectivos, utilizando políticamente el registro para establecer lazos y contactos, sino también para que otras personas o grupos se apropien de las imágenes y técnicas. Nuestro propósito es que estas imágenes sean móviles y que no se transformen en un documento cerrado, que se reelaboren y se reconstruyan en el intercambio con otros (GAC, 2009, p. 20o).

La "movilidad" nos conectó con la circulación, indispensable para volver a activar las potencias de la imaginación colectiva (GAC, 2009, p. 259).

[...] existen formas de circulación que no dependen de los altos costos o la publicidad, sino más bien de un

68. Aqui, estou entendendo movimento não apenas como "movimento social", mas como o movimento de performatizar a própria dor, dando uma forma espacial e pública a ela. 
sondeo de las experiencias vividas en la ciudad, capaz de detectar los canales posibles de la intervención, los puntos estratégicos desde los que lanzar el mensaje y la energía para permanecer e intervenirlos. Cuando esto sucede, la circulación deja de ser mera difusión de lo producido y se vuelve una instancia más de la producción colectiva (GAC, 2009, p. 271-272).

Apesar de terem constituído um repertório muito grande de imagens, vamos aqui nos limitar a dois tipos de imagens produzidas pelo coletivo. O primeiro consistia em placas de trânsito, iguais às pla- $^{-}$ cas oficiais, porém com dizeres que continham a localização da casa dos genocidas: "a 500 metros vive um genocida", "a 200 metros vive um genocida"; ou o nome do genocida com o endereço de sua casa. Durante as marchas para o escrache, o grupo colocava as placas na cidade.

La gran transformación que implicó para nosotras pensar la imagen en el escrache tuvo que ver, por un lado, con el lenguaje: con la idea de tergiversación de un código determinado (el vial urbano); $y$, por otro, con la idea de acontecimiento temporal que se reitera (el escrache mismo lo es) como irmupción festiva, del cual los carteles son la buella, lo que queda 'despues de'. La periodicidad misma del escrache posibilitó el surgimiento de un tipo de imagen serial, que reaparece cada vez. Además de marcar un trayecto, las señales marcan un tiempo, intervalos de tiempo, mediados entre escrache y escrache, y también entre el escrache y otros espacios donde 


\section{aparecieron los mismos carteles copiados por otros grupos (GAC, 2009, p. 8I).}

Uma outra imagem criada pelo GAC foi a cartografia "Aquí viven genocidas". Tendo o mapa da cidade de Buenos Aires como suporte, marcaram as casas de genocidas que já haviam sido "escrachados". Abaixo, colocaram como legenda os nomes, telefones, endereços de tais genocidas. Esta cartografia foi impressa e colocada na cidade, o que torna evidente a necessidade de criar uma legibilidade para a disputa, através de uma ferramenta - a cartografia - que possibilita dar visibilidade às paisagens psico-sociais, políticas e afetivas que se fazem a partir do movimento (Rolnik, I989). A disputa do simbólico ocorre aqui no sentido de que este efetivamente é produzido pelo concreto, assim como o produz. Portanto, a possibilidade de estabelecer a circulação simbólica das problemáticas situadas determina a difusão de novas formas de entendimento cognitivo sobre antigas questôes, valores e parâmetros. Neste caso, de uma forma de negociar o próprio conceito de justiça.

A partir dessas açóes, o Estado passou a rever as políticas de aplicação da justiça no caso dos torturadores e ex-militares, que agora estão sendo punidos e presos. Este é um caso bastante revelador de como os movimentos sociais contemporâneos se relacionam com a produção de imagens levando em conta a escala do corpo no embate com a cidade, fundamental no sentido de que é nesta escala que os processos de disputa pelo projeto de sociedade em curso efetivamente se espacializam, se tornando visíveis e legíveis.

Hay una idea fuerte que el escracbe propicia, una idea de justicia que desborda la representación de la 
justicia legal: se trata de la justicia que construye la gente día a día, a través del repudio al genocida en el barrio, la reapropiación de la política y la reflexión de las problemáticas del presente. [...] Por este motivo la práctica del escrache se centra en la memoria viva, creadora y en acción, generando prácticas politicas mediante la alegria, lo festivo y la reflexion. Se aleja asi de las prácticas del Poder Fudicial, que cosifica e individualiza los problemas sociales, y genera un espectáculo representado en la práctica del juicio (GAC, 2009, p. 58). 


\section{Circulação: o local e o deslocado, encontro do GAC com coletivos de São Paulo e contaminações}

O potencial de deslocamento dos símbolos e imagens produzidos a partir de problemáticas locais, vem colado à pergunta do porquê nos vemos muitas vezes identificados com contextos diferentes dos nossos. Certamente, o corpo em risco a enfrentar a cidade é um desses aspectos que mobilizam um certo "lugar comum".

Se em algumas imagens produzidas pelos coletivos, o corpo não está em evidência, vê-se ali um corpo, mesmo que ausente, pela própria característica de tais práticas: nelas, o não formal disputa o espaço com o formal, utilizando para isso as bases e formas da cidade, que parecem a princípio "imutáveis" e inegociáveis. No lugar do formal aparece, portanto, uma outra simbologia, um outro código, uma outra frase, uma outra forma de experimentar o espaço, um ato de $s o^{-}$ breidentificaçãa $0^{69}$ que só poderia ter sido realizado por "pessoas de carne e osso". Acredito que a potência de contaminação dessas práticas urbanas tenha tudo a ver com esse sinal da presença de um corpo humano situado, pensante, ativo e, por isso, político.

Quando o corpo se propóe, seja pela presença ou pela ausência, a fazer uma intervenção no espaço urbano, aparece ali, na produção tática da imagem, a escala humana tentando inventar uma outra forma de experienciar o espaço. Essa tentativa de invenção de espaço, que é em si um espaço de anúncio, talvez seja exatamente o que dá, à imagem produzida, a sua potência de circulação e reverberação em outros corpos e outras ações, portanto, a sua potência estético-política. Sobre isso, nos diz o GAC:

69. Sobreidentificação é um termo proposto pelo GAC. O grupo se refere a um tipo de intervenção na qual um código existente é utilizado para desdobrar outros significados. Por exemplo, a utilização das imagens estatais (logotipos, fontes, placas de trânsito), para expressar uma crítica ao próprio Estado. "Al sobreidentificarnos con esta institución, usurpamos los roles y vestimentas supuestas y esperadas de una institución gubernamental. [...] Cada institución, además de su significación concreta, tiene una función simbólica en la gramática cultural, ya que transmiten valores culturales, sociales y políticos" (GAC, 2009, p. 158). 
Del mismo desarollo de estas prácticas comunicacionales se desprende la idea de articulación con otros grupos o personas. En este sentido es importante dejar en claro que no nos referimos a una red impuesta o preexistente, constituida por un organismo tal al servicio de tales actores comunitarios, sino de la misma experiência y contacto humano de trabajo, que genera un vínculo entre personas y agrupaciones que comparten visiones y vivencias y que colaboran generando espacios que quiebran con lo establecido, en cuanto sistema de cosas, no por contraponerse, sino por ponerse a construir desde otro lugar. Trabajar con otros tanto en redes como intergrupalmente es apuntar a que el trabajo que de alli surja sea parte de una experiência comunicativa que se despliegue desde ese 'ser comunidad' a partir de entornos y actores diferentes, que se concreta al interactuar con la acción de intervención que es presenteada como conflicto puesto en la escena cotidiana. Desde alli se abre un nuevo nivel de multiplicación de la comunicación, en el que las distintas reacciones o respuestas no están previstas, sino más bien conectadas al accionar de los/las sujetos/as. Yla interpretación y reinterpretación de estas acciones dependem de las prácticas comunicativas que se desarollen dentro de esos contextos o circuitos (GAC, 2009, p. 174). 
É necessário e fundamental fazer com que as estratégias se transformem em formas simbólicas que possam ser difundidas e deslocadas, servindo de inspiração para outros atores, em outros contextos sociais. Pois é somente em circulação que esses acontecimentos situados, transformados em imagens de um projeto de cidade-sociedade, formam uma rede mais ampla de pensamento e ação, ganhando algum poder de fato nessa disputa.

Em 2004, aconteceu um encontro informal entre alguns integrantes de coletivos de São Paulo e o teórico, artista e ativista Brian Holmes $^{70}$. Nesse encontro, Holmes apresentou diversos trabalhos de grupos e movimentos de outros lugares do mundo, no intento de fazer com que os coletivos paulistas entendessem que estavam inseridos em um contexto mais amplo, e que existia toda uma rede de pensamento e ação, com a qual podiam começar a partilhar.

As soluções encontradas pelo GAC nos escraches e nas lápides espalhadas por Buenos Aires dando visibilidade aos assassinados em 20 de dezembro de 200 , chamaram a atenção de todos. Principalmente por subverter códigos oficiais ao introduzir mensagens que trazem à tona traumas, marcando, assim, a cidade, a partir do terrorismo de Estado e, com isso, deslocando-o de um lugar "ideológico" e de uma crítica muitas vezes angustiada, na qual a vítima se individualiza e sofre em silêncio. Parecia que aquilo também dizia respeito à nossa realidade, e que depois de muito tempo, a nossa experiência em relação à ditadura militar no Brasil estava encontrando um eco. Víamos ali "uma potência que nos potencializava", nos dava vontade de agir; uma forma de falar sobre a memória, denunciando-a para anunciar a emergência do contemporâneo.

Depois disso, alguns coletivos decidiram escrever e captar recursos para um projeto que potencializasse essa "partilha do sen-

70. Eu estava presente nessa conversa, assim como outros integrantes do Contrafilé. 
sível" (Rancière, 2005). O projeto "Zona de Ação" (ZA) foi resultado dessa investida: Contrafilé, GAC, Frente 3 de Fevereiro, Cobaia, Bijari, Suely Rolnik e Brian Holmes juntos (Peter Pál Pelbart participou apenas como palestrante), para entender o que podia ser feito. Abaixo, o que diziam os releases (significativos do momento em que estávamos) das conferências que aconteceram durante o $\mathrm{ZA}^{7 \mathrm{r}}$ :

2uais são as regras do jogo da imagem no mundo do capitalismo integrado? Em sua conferência, Brian Holmes e Suely Rolnik descreverão a maneira como os indivíduos são tomados nas redes mundiais de distribuição e de valorização de identidades-fetiche. Mas também como os produtores de acontecimentos urbanos podem transformar as regras do jogo social e construir uma autonomia partilhada72.

Palestra de Peter Pál Pelbart: "Poder sobre a vida, potências da vida": Trata-se de traçar um panorama do contexto biopolítico contemporâneo sob uma dupla perspectiva. Por um lado, evocando as novas modalidades de controle e de expropriação da vida. Por outro, mostrando o conjunto vivo de estratégias que lhe fazem face. Ao poder sobre a vida, responde a potência da vida. Assim, a questão da resistência pode ser repensada à luz da biopotência da multidão e de sua força de invençãa ${ }^{73}$.

71. As conferências foram feitas por Suely Rolnik, Brian Holmes e Peter Pál Pelbart, que tiveram um papel no projeto muito difícil de definir. Brian Holmes se diz um "teórico ativista". São pensadores orgânicos? Teóricos em ação? $O$ fato é que são pessoas que sabem produzir um pensamento colado com a experiência, com as urgências do real e que, por isso, têm um poder interventivo. Foi isso o que fizeram no projeto Zona de Ação.

72. In: portal do SESC. Link: http://www.sescsp.org.br/sesc/hotsites/za/, acessado em abril de 2012.

73. Idem. 
O projeto consistia na interação de cada grupo participante com uma zona da cidade (norte, sul, leste, oeste e centro) e, a partir dessa interação, em uma resposta que, de alguma forma, criasse uma inscrição político-simbólica significativa, que ajudasse a compreender melhor o lugar no qual vivemos e as formas possíveis de discutilo e reinventá-lo.

Com o apoio atento de Brian Holmes e Suely Rolnik, assim como dos outros grupos, inclusive do GAC - que ficou quinze dias em São Paulo com todos os seus integrantes e participou de forma muito ativa, trazendo muitas contribuiçōes -, os coletivos envolvidos puderam, aos poucos, entender aquilo que estavam sentindo a partir do processo, dando forma a essas sensaçôes.

O "Programa para Descatracalização da Própria Vida", do Contrafilé, é claramente resultado de todas essas interações. Em um primeiro momento, o grupo se sentiu profundamente incomodado pelo fato de "ir à zona leste" como "uma encomenda" e, pior, inventada pelos próprios coletivos ${ }^{74}$. Começou a realmente se questionar se aquilo fazia sentido, pois, se a possibilidade de se rever a cada instante a partir de "encontros" é fundante desse tipo de trabalho e atitude, o "encontro" a partir de uma estrutura dada e financiada, passou a ser algo muito incômodo.

O Contrafilé levou essa questão para as reuniōes coletivas do $\mathrm{ZA}$, e todos ficaram indignados com o fato de que estava considerando a possibilidade de não ir à zona leste e de não fazer o trabalho lá, mas fazer uma inscrição simbólica na cidade que de alguma forma trouxesse esta problemática "do encontro somente através de uma estrutura dada", à tona. A indignação dos outros grupos se deu muito no sentido de que parecia, para eles, que o discurso de "não ir à zona leste" estava em um lugar de "classe média", sem uma questão 
específica, querendo falar a partir desse lugar.

Depois de diversas reunióes com os "teóricos-ativistas" que acompanharam o projeto e com os outros grupos, além das próprias reuniōes, o Contrafilé decidiu que faria sentido realizar uma "Assembléia Pública de Olhares" com pessoas que representassem diferentes movimentos sociais da Zona Leste, desde que a sua inquietação daquele momento - "ir à zona leste por encomenda" -, fosse aberta para elas. "A Assembléia Pública de Olhares" é uma metodologia construída pelo grupo Contrafilé para colocar em pauta, junto a um coletivo mais amplo, sensaçôes e reflexôes a partir de experiências cotidianas, construindo com isso um projeto comum. Assim o grupo define esse tipo de Assembléia:

Assembléia Pública de Olhares sf 1 Encontro de pessoas com o fim de compartilhar o que as paralisa ou mobiliza; encontro de intimidades; 2 Criação coletiva de perguntas e exercício de dar nome às urgências; lugar de aprendizagem; 3 Prática coletiva de escutaativa que leva à produção de conteúdos e/ou símbolos resultantes da consciência de uma experiência comum; 4 Invenção de tempo e espaço para o dissenso; afirmação de singularidades co-criadoras de realidade; 5 Mobilidade interna; 6 Disponibilidade para relacionar-se com inteireza; 7 Descondicionamento de padrões repetidos; mudança de hábito; 8 Movimento de desatar os laços sociais previstos pelo Estado de Confinamento, espaço para relações proibidas; 9 Estado manifesto de criação.

Para a "Assembléia da Zona Leste", decidiu-se que seria apresentada a "catraca como um símbolo" representando, ao mesmo tempo, as impossibilidades e possibilidades que o Contrafilé sentia 
no próprio projeto: por um lado, o controle, a dificuldade de atravessar fronteiras visíveis e invisíveis; por outro, essa como uma experiência comum a todos, mesmo se provenientes de diferentes contextos sociais. Em conversas travadas com o GAC a partir do conceito de sobreidentificação, o coletivo decidiu, ainda, partir da "catraca como símbolo" para propor um "programa público". O GAC foi determinante nesse momento, já que tinham desenvolvido essa experiência de atuação a partir do deslocamento de discursos e símbolos oficiais como representaçáo direta no contexto urbano. Foi gerado, a partir disso, o slogan "Programa para Descatracalização da Própria Vida", imitando o logo oficial da prefeitura daquele momento ${ }^{75}$. Quando estava com esse dispositivo "em mãos", o Contrafilé se sentiu preparado para compartilhar a sua angústia em "Assembléia", a partir do lugar da potência e não da queixa.

75. Em 2004, Marta Suplicy era a prefeita de São Paulo e o logo era composto pelo desenho de vários "homenzinhos" de mãos dadas, imitando a imagem do recorte clássico de papel. 


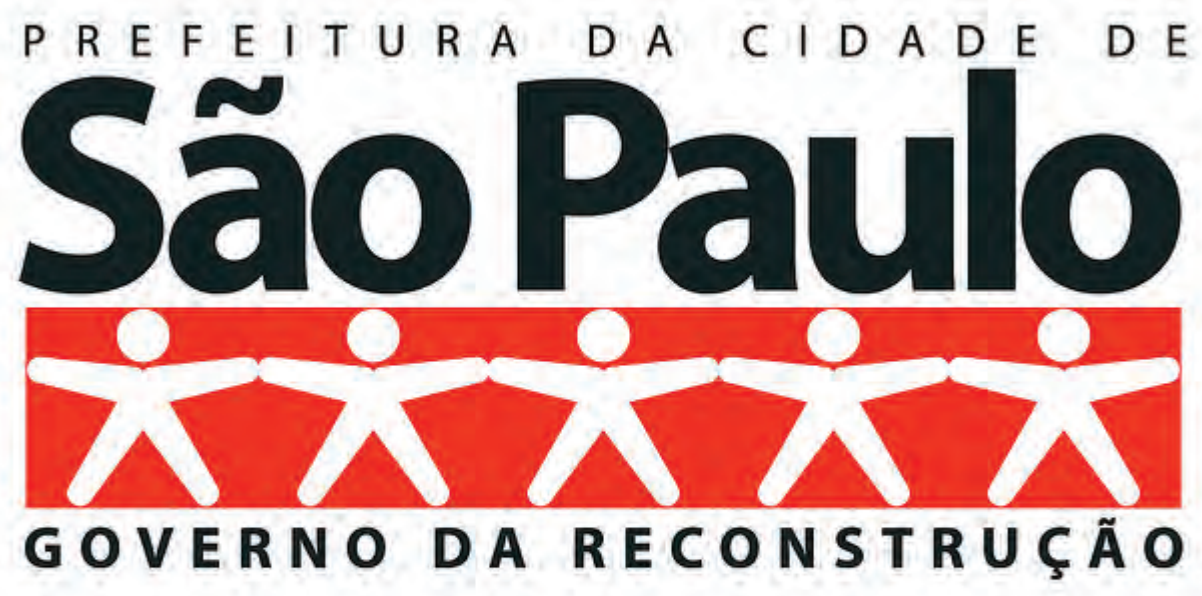

\section{Slogan}

prefeitura Marta

Suplicy 2004.

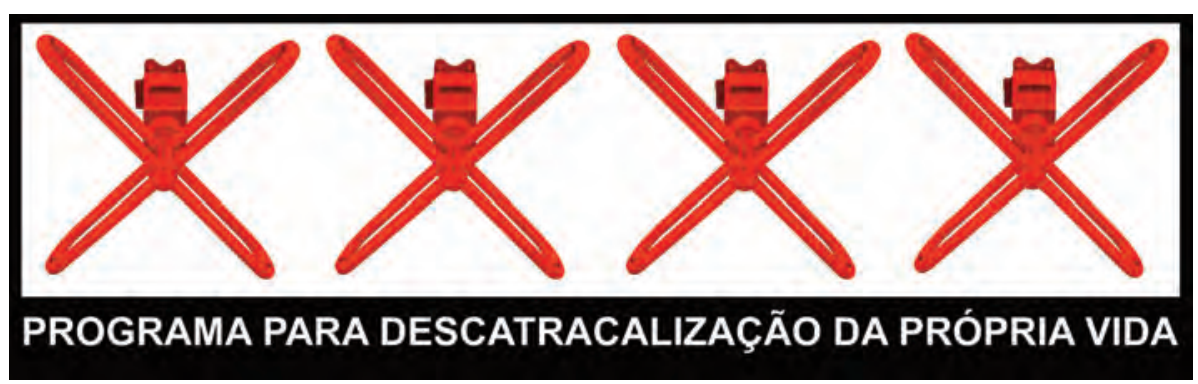

Slogan "Programa

para Descatracalização

da Própria Vida, 2004. 


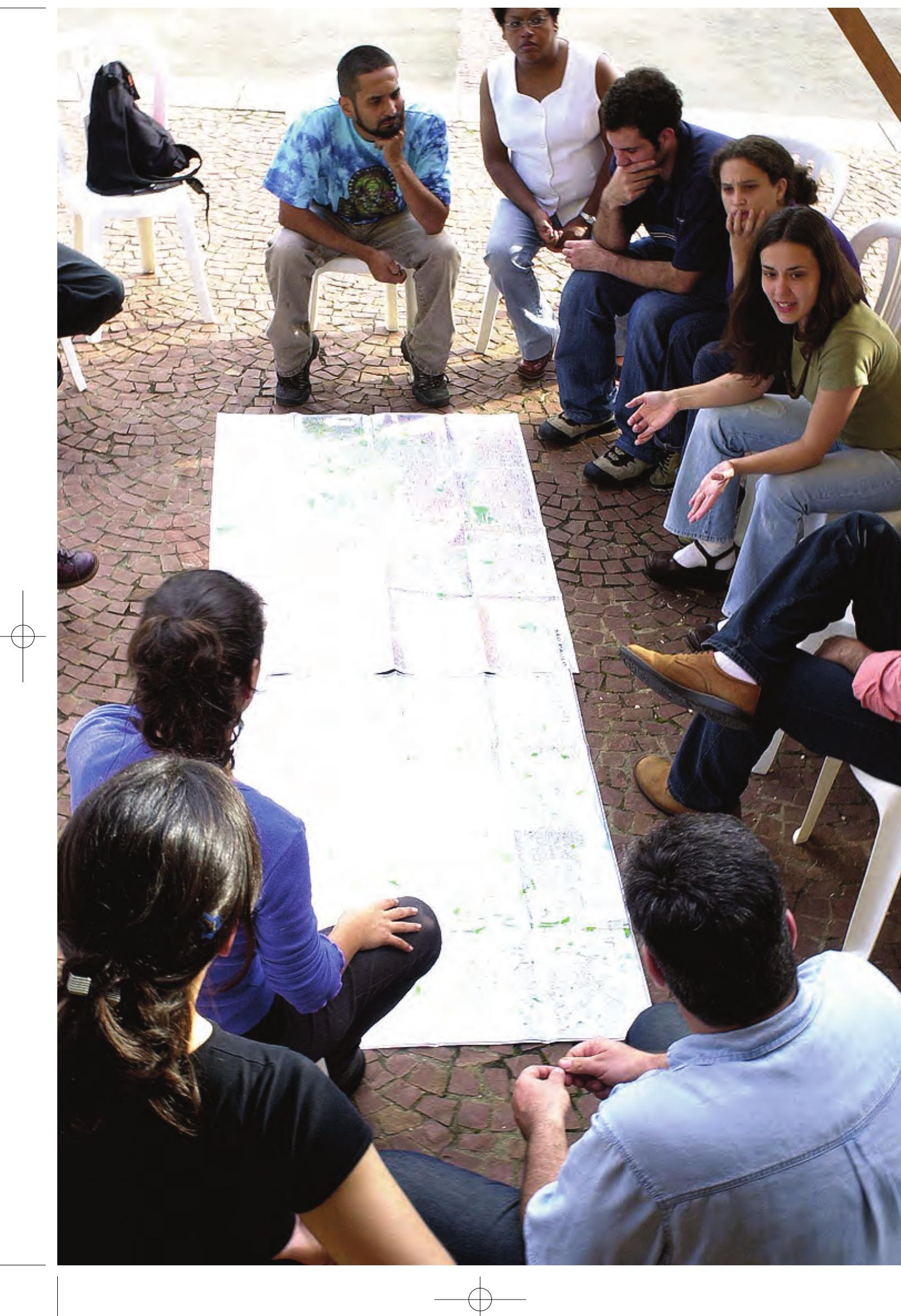




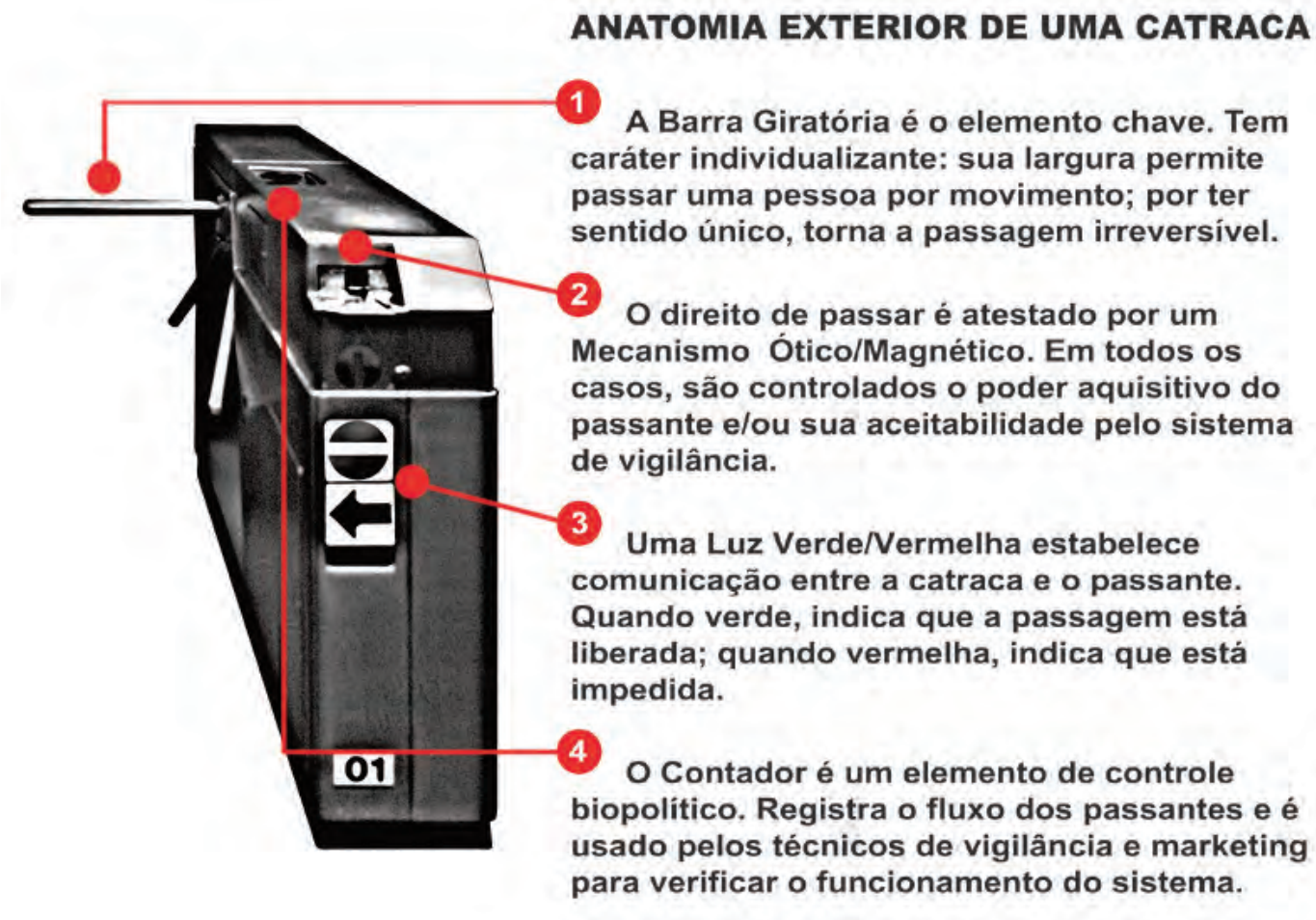

Imagem produzida pelo Contrafilé simbolizando essa espécie de "dissecação da catraca" feita pelo grupo para compreender a reverbaração da catraca como símbolo no imaginário das pessoas. 
Com essas conversas, ficou evidente que esse era, de fato, um símbolo potente já que mobilizava as pessoas a refletirem, ficarem indignadas, rirem, chorarem, contarem as suas histórias de vida. No dia seguinte, foi então proposto que se pensasse coletivamente em como transformá-lo em uma intervenção na cidade. Assim, ideias foram surgindo, formas de inaugurar o "Programa para Descatracalização da Própria Vida": queimar uma catraca na frente de uma igreja e escrever "uma catraca para o céu"; colocar catracas em lugares absurdos e ver se formava uma fila; queimar uma catraca na frente da Daslu ${ }^{76}$. Até que chegou-se na ideia de fazer um "Monumento à Catraca Invisível". Nada mais apropriado para inaugurar o "Programa".

O próximo passo seria pensar o lugar mais preciso para que a proliferação da ideia-símbolo a transformasse efetivamente em uma ocorrência: construir um pedestal ou se apropriar de um já existente? Fazer na Zona Leste ou no Centro? Depois de muita discussão, a conclusão foi de que seria mais interessante se a catraca fosse instalada no centro, lugar que representa a todos, onde confluem diferentes pessoas e regióes. Também, de que seria mais forte colocar a catraca em um pedestal do qual o busto tivesse sido roubado, pois assim esta entraria, enquanto símbolo, em relação com a forma como os símbolos oficiais são construídos e desconstruídos na dinâmica da cidade. Depois disso, foram pensados os detalhes da placa, o lugar mais apropriado foi encontrado (Largo do Arouche), etc.

A instalação da catraca (que foi comprada em um ferro velho), necessitou de toda uma estratégia, já que há uma base da PM no Largo do Arouche: o grupo se vestiu com roupas de funcionários da prefeitura (tipo gari) e, de madrugada, colocou a catraca em um pedestal vazio. Assim constava na placa colocada no pedestal, que copiava as placas das estátuas da praça:

76. Loja de roupas e artigos de luxo para milionárias, localizada em São Paulo. Muitas vezes acionada como símbolo pelos brasileiros, quando querem se reportar à desigualdade social e os absurdos e perversões que produz. 


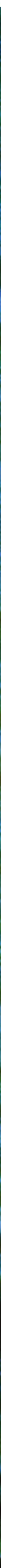

Monumento à Catraca Invisível.

Largo do Arouche, São Paulo,

junho de 2004. 


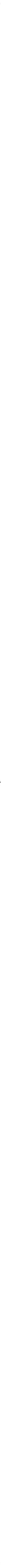
2

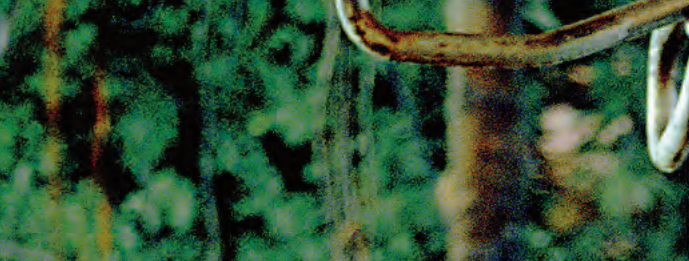

(3) 


\section{"Monumento à catraca invisível" Programa para a Descatracalização da Própria Vida Funbo/2004}

Instalada a catraca em junho de 2004, de forma anônima (o que foi uma discussão com o Sesc, que queria que o grupo assinasse a intervenção), em setembro foi noticiada pelo jornal Folba de São Paulo sua "presença" no caderno Cotidiano. A notícia, intitulada "Catraca invisível' ocupa lugar de estátua no Arouche”, foi acompanhada de uma foto onde se via a catraca em meio a dois bustos, com a legenda: "Catraca em pedestal no Arouche; no detalhe, placa destaca programa de 'descatracalização' da vida”.

Sem que ninguém saiba como - e muito menos o porquê - uma catraca enferrujada foi colocada em cima de um pedestal no largo do Arouche (centro de São Paulo), local antes ocupado pelo busto do escritor Guilherme de Almeida (1890-1969) ${ }^{77}$.

Vemos nas aspas que acompanham algumas palavras da notícia, como "catraca invisível" e "descatracalização", uma requalificação produzida na notícia para o evento, o que evidencia uma disputa pela construção das representações na cidade e sobre ela. Para uma "explicação" sobre a aparição da catraca, a reportagem da Folba buscou as autoridades responsáveis pelos monumentos na prefeitura, a polícia e a comunidade local. O pedestal ocupado pela catraca situa-se em frente à Academia Paulista de Letras, “ao lado da escultura 'Depois do Banho' de Victor Brecheret, e de mais quatro pedestais, um deles também sem o busto de bronze", descreve a reportagem. É, portanto, um espaço de 
representação da cultura oficial da cidade (Domingues da Silva, 2006).

O texto da reportagem se atém à uma discussão sobre vandalismo e patrimônio público e tenta encontrar os responsáveis da autoridade da prefeitura em relação ao vazio deixado pelo furto e à ocupação indevida do pedestal. A autoria desconhecida e o gesto anônimo sobre a cidade produziram, claramente, uma negociação e inquietude em relação aos seus possíveis sentidos. Podemos ver isso na própria construção do texto da notícia da Folha (id.ibid.):

O aposentado Vital Antonio, 55, passa grande parte do dia na praça e achou o novo monumento 'sem sentido'. 'É uma palhaçada. Poderiam ter colocado outro busto no lugar', diz. [...] Segundo comerciante e frequentadora da região, a catraca apareceu há cerca de dois meses, mas o busto foi furtado há anos. $7^{78}$

Valéria Valeri, coordenadora da comissão de esculturas do DPH (Departamento do Patrimônio Histórico), órgão da prefeitura, disse que:

A 'presença da catraca foi constatada em vistoria feita na semana
passada e a sua retirada já está sendo providenciada [...]'. De acordo
com a coordenadora, é a primeira vez que vê um objeto desse tipo
em cima de um pedestal, mas que écomum o furto de estátuas eprin-
cipalmente de placas de bronze. (id.ibid.)

A reportagem questiona, a todo momento, a legalidade da situação e, por isso, existe na construção dos discursos, tanto da Folha quando do DPH, uma necessidade de restaurar uma suposta ordem o mais rápido possível para "estabilizar o sentido do acontecimento". 
PAtrimónio abandonado Nem a prefeitura sabe explicar como equipamento enferrujado foi parar no local

\section{'Catraca invisivel' ocupa lugar de estátua no Arouche}

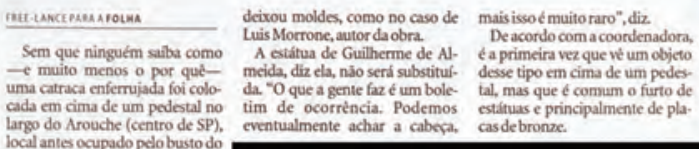

deixou moldes, como no caso de maisissó muntor in Morrone, autor da obra. De acordo com a coordenadora, A etatua de Guilherme de Al- éa primeira vez que vé um objeto "O que a gente fá éumbole tal mas que teonum o furto de tim de ocorrència. Podemos estítuas e principalmente de pla. cventualmente achar a cabeça, casdebronze

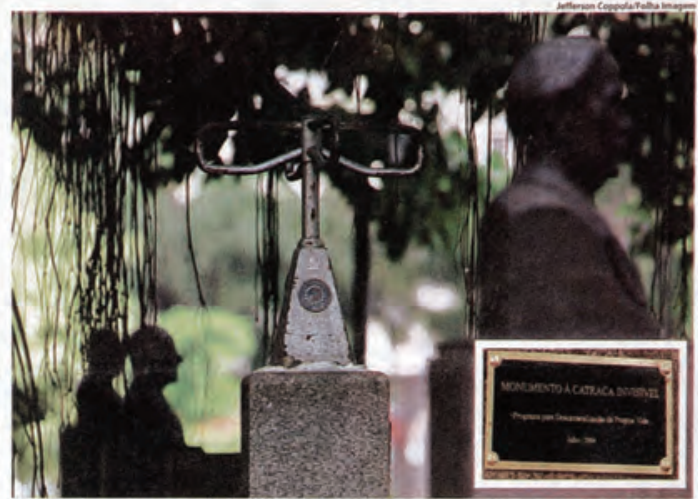

Catraca em pedestal no Arouche; no detal he, placa destaca programa de 'descatracalizacio' da vidi
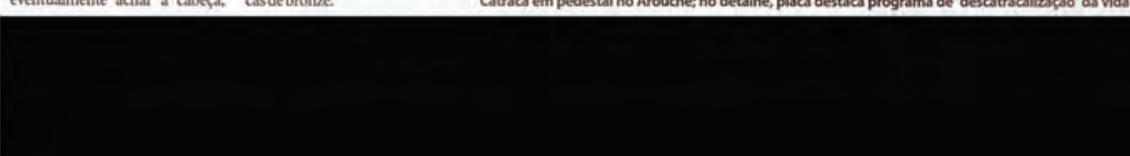

.

Folha de São Paulo, Caderno Cotidiano, 4 de setembro de 2004. 
A catraca estava deslocada do espaço em que se constitui objeto próprio a um controle, o controle, justamente, do público, particularizando a passagem dos corpos, em uma funcionalidade que rege a sociabilidade dos espaços: separando dentro/fora, público/privado, distinguindo sujeitos em comunidades que não integram a todos (mas somente aqueles que têm credencial, que mostram a carteirinha, ou os pagantes), enumerando-os e contabilizando-os. E, no pedestal, viria ocupar indevidamente o lugar de monumento, mas como abertura de sentido e não fechamento (Domingues da Silva, 2006).

No Monumento à Catraca Invisível, a nomeação que a placa realiza evidencia que a catraca não era um acaso, mas índice de que "outras histórias" estavam não apenas pensando-se a partir do espaço urbano, mas também desejando agir e efetivamente agindo sobre ele. A catraca aparecia, portanto, como conceito, uma catraca-símbolo, lembrando ao cidadão todas as dobras que se encontram disseminadas pela sociabilidade do/no espaço urbano e que, de forma muitas vezes imperceptível, contribuem para o estabelecimento das suas fronteiras (id.ibid).

\section{Houve quem enxergasse a catraca como simbolo de algo que emperra, dificulta. $E$ isso pode ser literal ou subjetivo. Existem 'catracas' que impedem as pessoas de chegarfisicamente a um lugar, radiais, avenidas ou rodoanéis com trânsito difícil. Existem também as catracas sociais, as raciais e as históricas, que difícul- tam a vida de outras maneiras. 79}

79. Trecho de entrevista do grupo Contrafilé, extraído do artigo Palavra da Revista e $n^{\circ} 95$, publicação do Sesc-SP. 
A catraca/descatracalização, migrou no espaço do mesmo jornal, aparecendo em diversas tiras de HQ do cartunista Laerte, que acionou a sua personagem "Homem-Catraca", agora como um "agente da descatracalização". Depois, em encontro com o cartunista, o Contrafilé ficou sabendo que, vendo o "Monumento à Catraca Invisível", no próprio dia em que apareceu na Folha como "ato de vandalismo", sentiu-se convocado a retomar a sua crítica, atualizando-a a partir do ato de enunciação produzido pelo grupo. Pouco tempo depois, de forma mais surpreendente ainda, a ação atingiu o Vestibular da USP, como tema de Redação da Fuvest de $2005^{80}$, e também textos opinativos e de publicidade. O "Monumento à Catraca Invisível" foi legitimado pela universidade, o que também gerou muito debate e dissenso, especialmente centrados na palavra "descatracalizar" e no fato da Universidade de São Paulo usar um "neologismo" - que absurdo! - como tema de redação.

Após o vestibular da Fuvest, vários eventos sucederam-se. No dia seguinte, o banco Itaú colocou outdoors na cidade, assim como anúncios em revistas e na própria Folha, que diziam: "Vestibulando, Descatracalize a sua Vida, Abra uma Conta no Itaú". Logo depois, o movimento estudantil queimou uma catraca na frente do prédio da Fuvest, em uma manifestação contra a taxa que deve ser paga para prestar o exame. A partir disso, a catraca pegando fogo tornou-se o símbolo do Movimento pelo Passe Livre, que luta pela gratuidade do transporte público para os estudantes.

Articulistas tanto da Folha quanto da Revista Bravo e do $E^{-}$ tado debateram o assunto. Fernando Barros e Silva, da Folha de São Paulo, por exemplo, escreveu um artigo no qual dizia que, embora a instalação do "Monumento à Catraca Invisível" fosse "simpática" e "provavelmente melhor do que muita obra da Bienal", o uso dela 


\section{Fuvest 'catracaliza' o idioma}

Tema da redaçãoda 2. a fase foi a 'descatracalizaçãoda vida', palavra usada para simbolizar os obstáculos

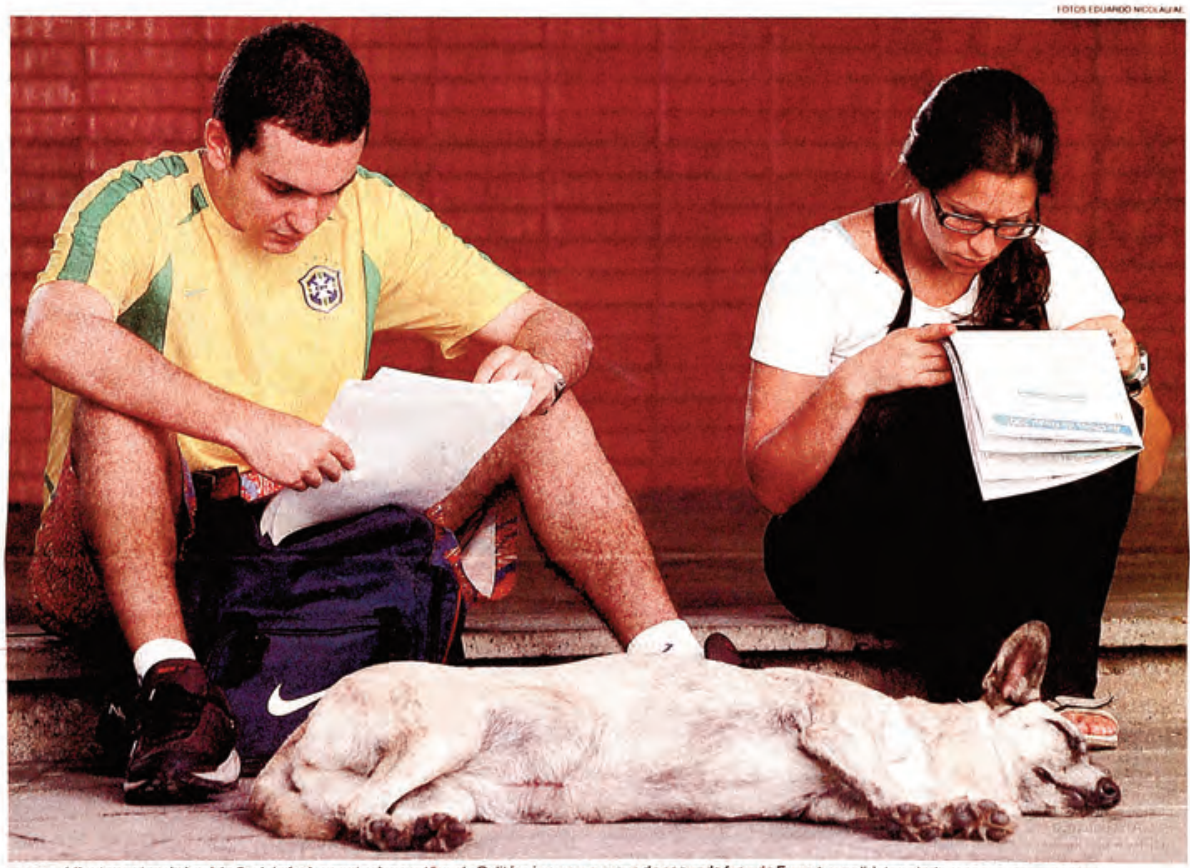

NOTAS

SEMANA DE VESTIBULAR

Exames da segunda fase vão até quinta-feira

A segunda lase da Fuvest vai até quinta-teira. Os locais de exame serảo os mesmos. De vestibulando fará as provas das disciplinas indicadas pela Fuvest. A partir de hoje, nenhum candidato tera do lazer dois exa. mes por dia. Seráo sempre dez questoes dissertativas, que co. sảo abentos às 12 h 30 . räo as provas de Historia mica. Amanhas $A$ a vez de Geografia e Biologia. Na quarta-fei$\mathrm{ra}$, os estudantes tazem os exames de Maternatica e, na quintaleira, os de Fisica. Cada vestibu. lando tará no máximo quatro provas.

\section{VACaS NA FUVEST} 9.567

de um total de 9.947 vagas stio na USP, incluindo o nov

\section{0}

na Santa Casa, en cursos de Medicina e Entermagem

150

na Academia de Policia Mili-

na Academia de Po
tar do Barro Branco

Pontuaudade

No Tatuapé, uma única aluna nảo chega a tempo Na Unip do Tatuape uma única vestbulanda nà conseguiu che. gar a tempo. Aline Ribeiro (loto). de 19 anos, perdeu sua chance porconta de um atraso de 15

O Estado de São Paulo, 10 de janeiro de 2005.

VEStiBular Segundo professores, prova exigiu que aluno usasse subjetividade no texto; hoje hả exames de história e de química

\section{Fuvest usa catraca enferrujada como tema da redação}
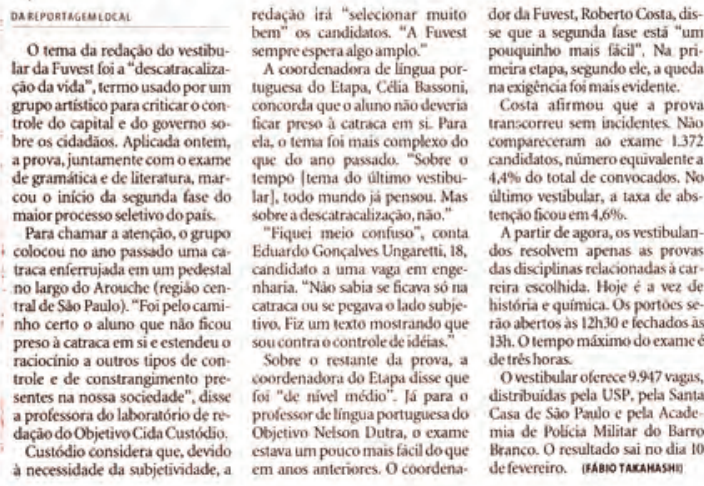
estava um pouco mais facil do que Branco. O resultado sai no dia à necessidade da subjetividade, a em anos anteriores. $\mathbf{O}$ coordent.

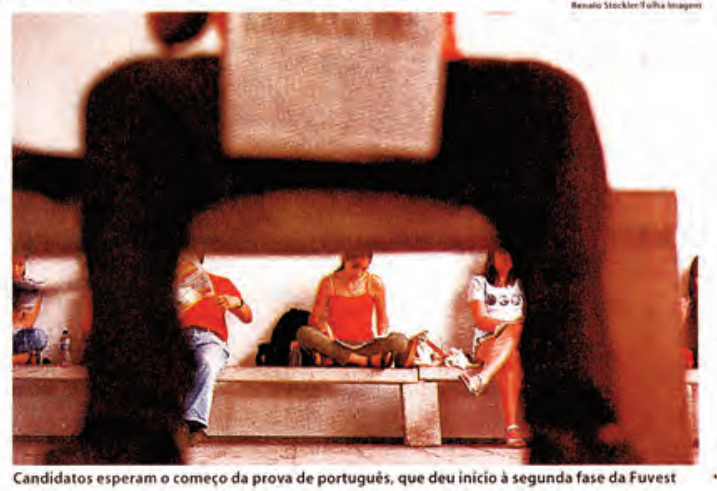

Folha de São Paulo, 10 de janeiro de 2005. 
como tema da Redação da Fuvest mostrava um espírito "68 requentado" que teria contaminado os examinadores da Fuvest. Criticava também a complexidade do tema, perguntando se a intenção era a de que os alunos discorressem sobre o "homem unidimensional de Mar cuse" ou a "microfísica do poder" de Foucault e o que "um jovem morador de Guaianazes pensaria sobre a descatracalização do busão lotado".

Ao que Maria Tereza Rocco, vice-diretora da Fuvest, respondeu:

\section{[...] O que pretendia a banca examinadora ao propor o tema? $R e^{-}$} ceber textos bem escritos, mas sem nenbum preciosismo ou academicismo. Textos que dessem conta de um tema que nos atinge a todos. [...] Diferentemente do que o jornalista registrou em seu texto, também os candidatos de Guaianazes pensam, refletem e vão fundo! Eles não se limitam, não, a se preocupar tão-somente com a 'descatracalização do busão lotado's.

Com essa sucessão de acontecimentos a partir do "Monumento à Catraca Invisível”, o "Programa para a Descatracalização da Própria Vida" não só foi inaugurado, como de fato pôde disputar, simbolicamente, diversas questões normativas: a decisão por aquilo que se monumentaliza, a existência ou não de uma taxa para realizar o exame de uma universidade pública, o uso ou não de um neologismo em uma prova "formal". Assim como colaborou para evidenciar a rapidez do marketing em cooptar o poder de criação, os fluxos e saberes coletivos que são produzidos e circulam na cidade, privatizando-os ao transformá-los em estratégias de acumulação de capital. Podemos ver operando nessas construções discursivas, as formas de 
controle contemporâneas. Segundo Paolo Virno, em um mundo no qual o capital se reproduz a partir da expropriação da criatividade e da inovação:

\section{[...] la cooperación del trabajo social perderia parte de su poten- cia (y de su eficacia para la valorización capitalista) si fuese di- rigida y disciplinada en cada detalle. [...] Para el capitalista es necesario apropiarse de la innovación a posteriori, sellecionando en ella los aspectos afines a la acumulación y eliminando todo lo que puede dar lugar a libres instituciones de la multitud"(Virno, 2006, p. 13).}

O Contrafilé formalizou a sistematização como obra ao perceber o esvaziamento da crítica em muitos dos discursos mobilizados pelo "Monumento à Catraca...", quando estes eram vistos de forma fragmentada. Com isso, entendeu que a potência do trabalho residia, justamente, na possibilidade de desfragmentar os discursos, compreendendo-os como processo de produção social e, assim, invertendo a forma de funcionamento seletiva dos discursos hegemôni$\cos$.

Pois é nesse ato de colocar um discurso ao lado do outro, que se torna perceptível o desdobramento do fato inicial como a formação de um "agenciamento", no sentido que deram a esse termo Deleuze e Guattari ${ }^{82}$. Na medida em que os seus vários níveis se tornaram visíveis ${ }^{8_{3}}$, o "Programa" se converteu, efetivamente, em um "dispositivo para a articulação de uma enunciação coletiva" (Holmes, 2006, p. 146). É a imagem dessa multiplicidade de vozes o que o trabalho, como sistematização da experiência ou como "cartografia", possibilitou; assim como a efetiva transformação de eventos isolados

82. Ver capítulo 1.

83. A obra como produção de espaço, como complexificação do pensamento social sobre as fronteiras que subjugam o corpo na cidade e como dimensão trans-local e trans-histórica dos acontecimentos urbanos situados. 
Vestibulando,
descatracalize sua vida.

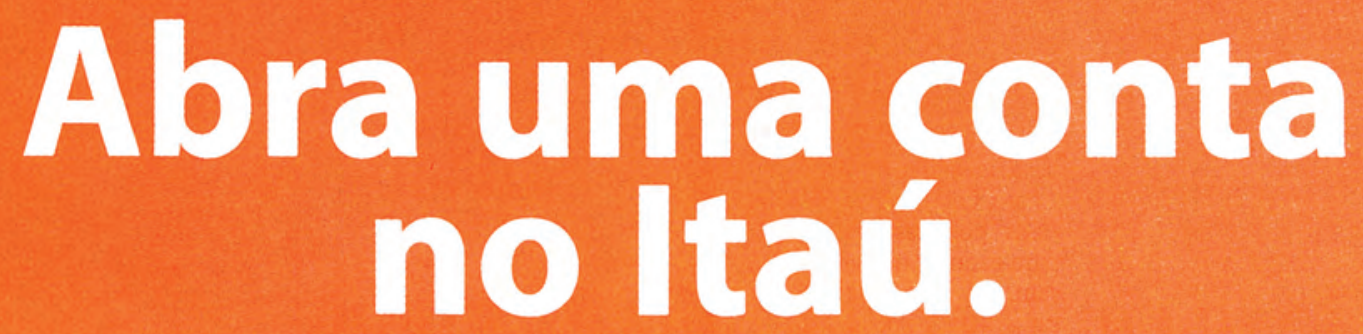

Itaú feito para vocề

Folha de São Paulo e outdoors

espalhados pela cidade de São Paulo,

10 de janeiro de 2005. 
Ayrton Vignola/Folha Imagem

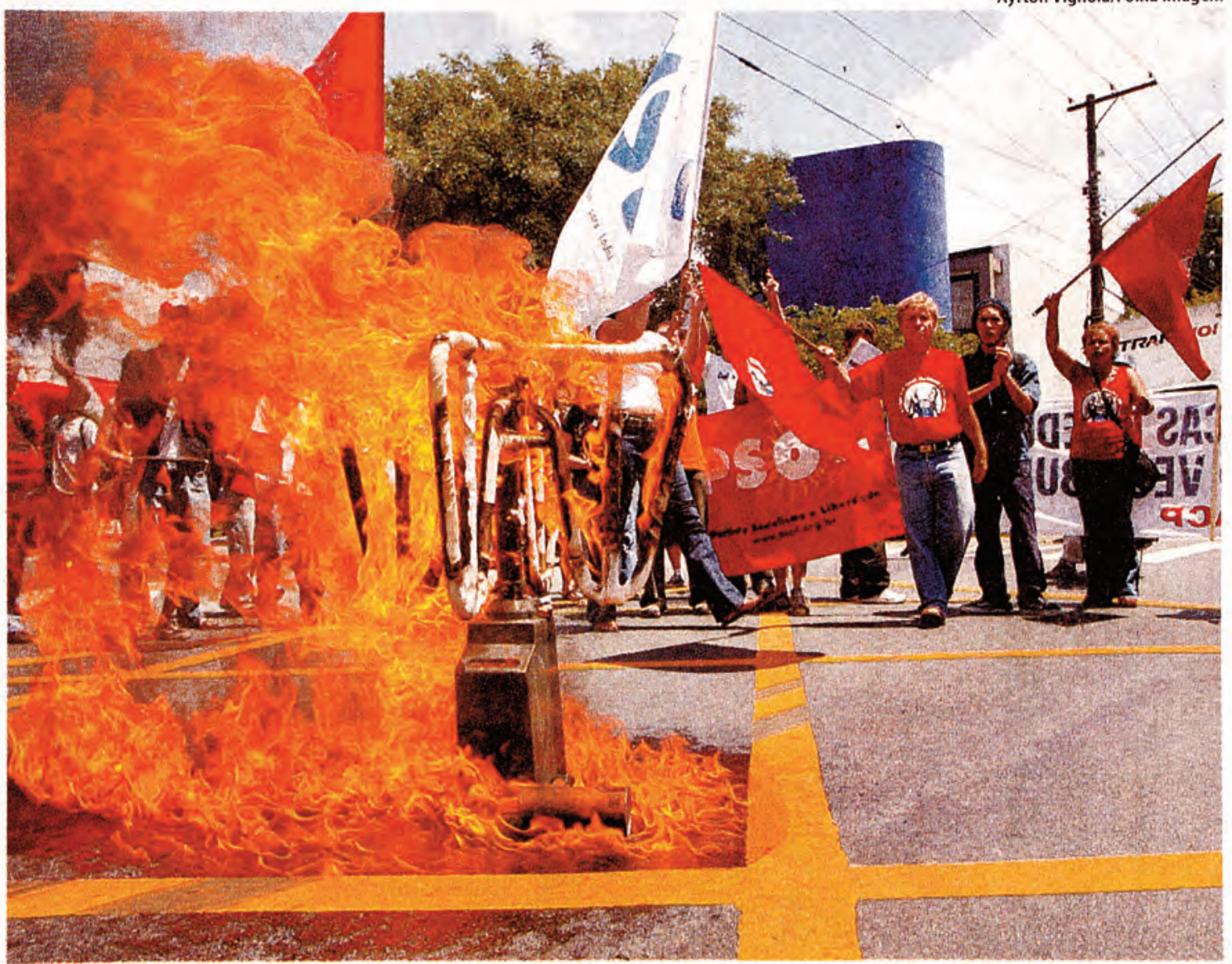

FOGO NA CATRACA Manifestantes incendeiam catraca antes de invadir prédio da Fuvest, cujo tema de redação foi a 'descatracalização da vida'; eles criticam a taxa do vestibular Pág. C7

Folha de São Paulo,

11 de fevereiro de 2005. 


\section{POR TRANSPORTE PÚBLICO DE VERDADE NENHUM CENTAVO A MAIS

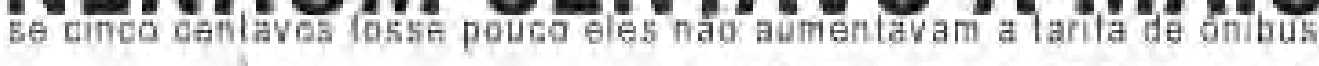

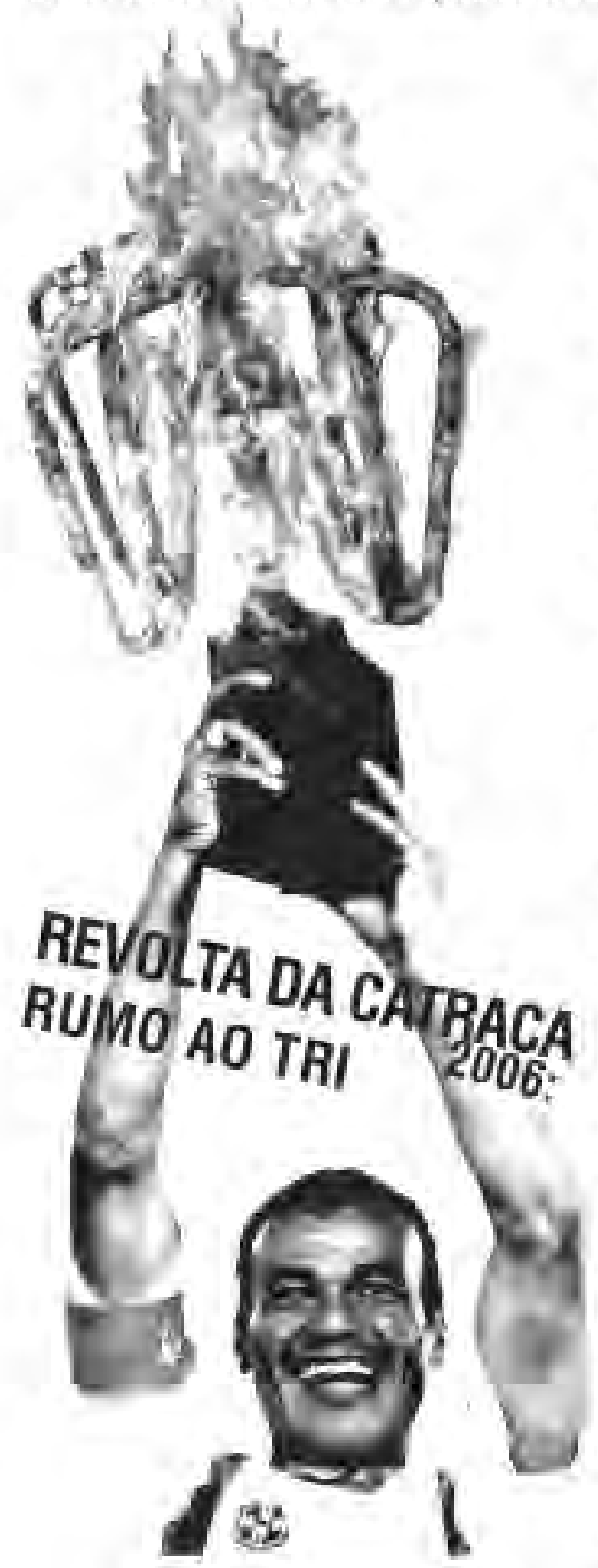

Enquianto cs craques da soleçầo enirentarầ o fria, ae bothas e todo lipo de cificuldada pra conqustar o hexa campeonalo, nós aqui em Florianopolis temos iarefa muito dificil e divertida a fazert Temos que resistir aos ataques que a prefeltura $e$ as empresas de ónibus aplicarn na população e mudar completamente o sistema de transporte!

Vamos tomar as nas, en elima de Copa do Mundo, a protestar uma vez mais contra - aumonic das lanfas Mas desta vez à

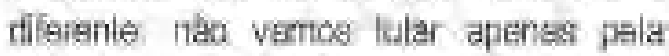
reduçáo das tarifas. Nossa exigància ê por transporte publibo de verdade.

E a TARIFA SOCIAL? Anles da lal lanla uricica (quie na verdade sāo quatro prep̧os) custava RS 1,05 a agora am dinhairo esła RS 1,351 Nä́o podemos nos espuecer de uाT

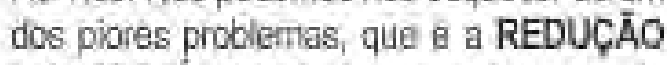
DOS HORARIOS. Linhas que deixaram de existi, thibus a menos, deixando o pevo enl pe durante quase uma hora nos pontos fribs a conde mal dá para sentar. É tambem è prectso de uma vez por todas unir a nossa luta com a populaçäo que usa os ÓNIBUS INTERMUNICIPAIS. Hà taritas que chegam a custa R5 4,30! Isso \& um absurdo!

Ventia para as manifestaobest Traga sua bola, a camisa do sou time preferida a chame amigos es anigas! Organize alos: ná suá comunidade! Vencernos em 2004. em 2005 e agora vamos para a Revolta da Catrexa 2006: RUMO AO TRI:!! 


\section{Pegadinha do Fuvestão}

SÃO PAULO - A Fuvest, desta vez, se superou. Exigiu anteontem como tema de redação do vestibular uma dissertação em torno do "Programa para a descatracalização da vida" -isso mesmo. Explico: no ano passado, um grupo de ativistas chamado "Contra File" colocou uma catraca velha sobre um pedestal no largo do Arouche, centro de São Paulo. A instalação foi batizada de "monumento à catraca invisível". Era uma maneira de criticar, segundo os próprios autores, o controle "biopolítico, através de forças visíveis e/ou invisíveis", a que estaríamos todos submetidos.

Com base nisso, a Fuvest pediu ao estudante que se posicionasse sobre $o$ "excesso de controles, dos mais variados tipos, que se exercem sobre os corpos e as mentes das pessoas" etc. etc.

Nada contra a simpática anarquia dos "Contra File", pelo contrário. Deve ter mais valor do que muita instalação da Bienal. O problema é o espírito meia-oito requentado que anima os examinadores da USP.
Soa regressivo. A começar pela construção infeliz - “descatracalização" dói nos ouvidos. Tratando-se da prova de redação do maior vestibular do país, seria de esperar, pelo menos, que desse o exemplo. Que tal "descatracalizar" primeiro a língua em que devemos todos nos comunicar?

$O$ que pretendiam, afinal, esses examinadores? Que os alunos discorressem sobre o "homem unidimensional" de Marcuse? Que dissertassem a respeito da "microfísica do poder" de Foucault? Que fizessem a apologia do "bom selvagem"? Francamente...

Dá vontade de ser um pouco grosseiro: perguntem ao morador de Guaianazes o que ele pensa da descatracalização do "busão"lotado...

Pretendendo despertar o senso crítico do pobre aluno, a redação só induz ao devaneio e a clichês sem substância. Coroa assim um processo de seleção torturante, burro e obsoleto.

A elite brasileira entra e sai da universidade lendo e escrevendo muito mal. Por que será? Perguntem ao pessoal da Pegadinha do Fuvestão. 


\section{Redação na Fuvest}

"Gostania de tecer alguns comentários em relaçio ao artigo 'Pegadinha do Fuvestāo' (Opiniāo, pág. A2, 11/1), de Fernando de Barros eSilva.

A Fuvest não admite 'pegadinhas'. Verificamos sempreseas propostas nas provas säobem feitas, não exigindo 'decorebas' e nảo permitindo que os candidatos entrem nas 'saias justas' que recobrem tais pegadinhas.

A Fuvest, diferentemente do que dizo jornalista, não solicitou que o estudante se posicionasse sobre o excesso de controles dos mais variados tiposquese exercem sobre os corpos eas mentes das pessoas'. Na proposta, le-se. 'Tudo indica (...) que o grupo responsível por este programa acredita que haja um excesso decontroles (...) etc. Tendoem vista as motivaçỏes do grupo, você julga queo programa por cle desenvolvido sejustifca? (...). Redija uma dissertaçäo em prosa argumentando de modo a apresentar seu ponto de vista sobre o assunto'. Assim, o vestibulando deveria posicionarse de maneira afirmativa ou negativa sobreotema.

Quantoà palavra 'descatracalizaçāo', nâocreio que 'doa nos ouvidos' para sempre. Trata-se de uma divertida brincadeira do grupo 'Contra Filé, um 'travalenguas', como se dizem espanhol. Fala- da pela primeira vez, a palavra nãoćfácil de ser pronunciada, mas logo se torna familiar.

Oque pretendia a banca examinadora ao proporo tema? Receber textos bem escritos, mas sem nenhum preciosismo ou academicismo. Textosque dessem conta de um tema que nos atinge a todos.Já temos como resultado da correça dos primeiros lotes de redaçóes um número bastante bom de textos que não fogem ao tema, bem articulados eque revelam, na maioria dos casos, um profundosenso crítico por partedos candidatos. Um senso crítico muito maiore mais agudo do que se pode imaginar.

Diferentemente do queo jomalista registrou em seu texto, também os candidatos de Guaianazes sentem, refleteme vão fundo! Eles nâo se limitam, não, a se preocupar tão-somente com a 'descatracalizaçio do busaiolotado'.

Quantoaos 'devancios', eles näo existem! 'Clichês', sim, alguns, mas não irreletidos. Eles permitem, ao con trário do que se pensa, a progressio dos textos.

Com enorme prazer, reafirmamos que essesjovens sio muito, mas muito meIhores mesmo do que as pessoas acreditam."

Maria Therezo Fraga Rocco, vice-dirctora da Fuvest (Sáo Paulo, SP) 


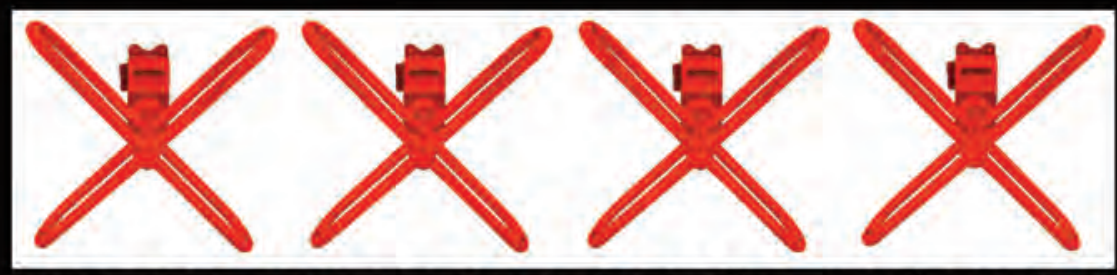

PROGRAMA PARA DESCATRACALIZAÇÃO DA PRÓPRIA VIDA

"A catraca moderna foi criada no inicio do século 20 como possibilidade de controle do acesso a parques de diversões e sistemas de trânsito. Aproximadamente 80 anos mais tarde, a catraca tornou-se um componente indispensável para a segurança, especialmente as empresas atualizar am essa invenção para se adaptar ao mundo pós 11 de setembro".

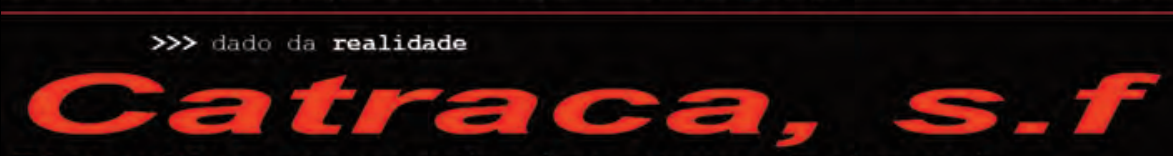

Dispositivo que permite girar suave e lentamente tudo o que não esteja sendo acionado por meios naturais

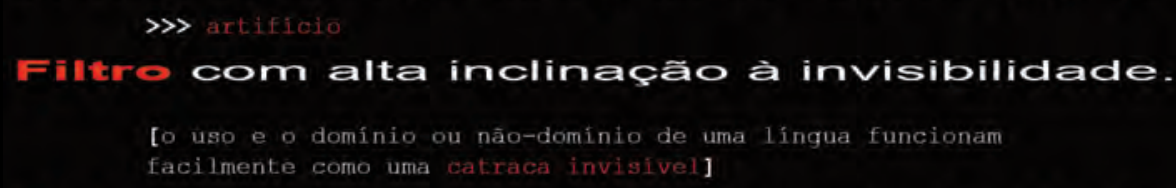

Roda com dentes inclinados, nos quais engata uma garra com o fim de rodá-la para um dos lados, evitando a rotação em sentido contrário.

$$
\text { « Borboleta que nào se permite dar uma volta completa 〉 }
$$

Emtracla potencialnente encerrada. $\gg$ Possivel abortado.

Frontoira visivel elou invisivel que separa lugares fundamentalmente indivisiveis.

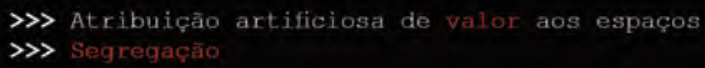

Lupa que evidencia divisōes criadas artificialmente. 

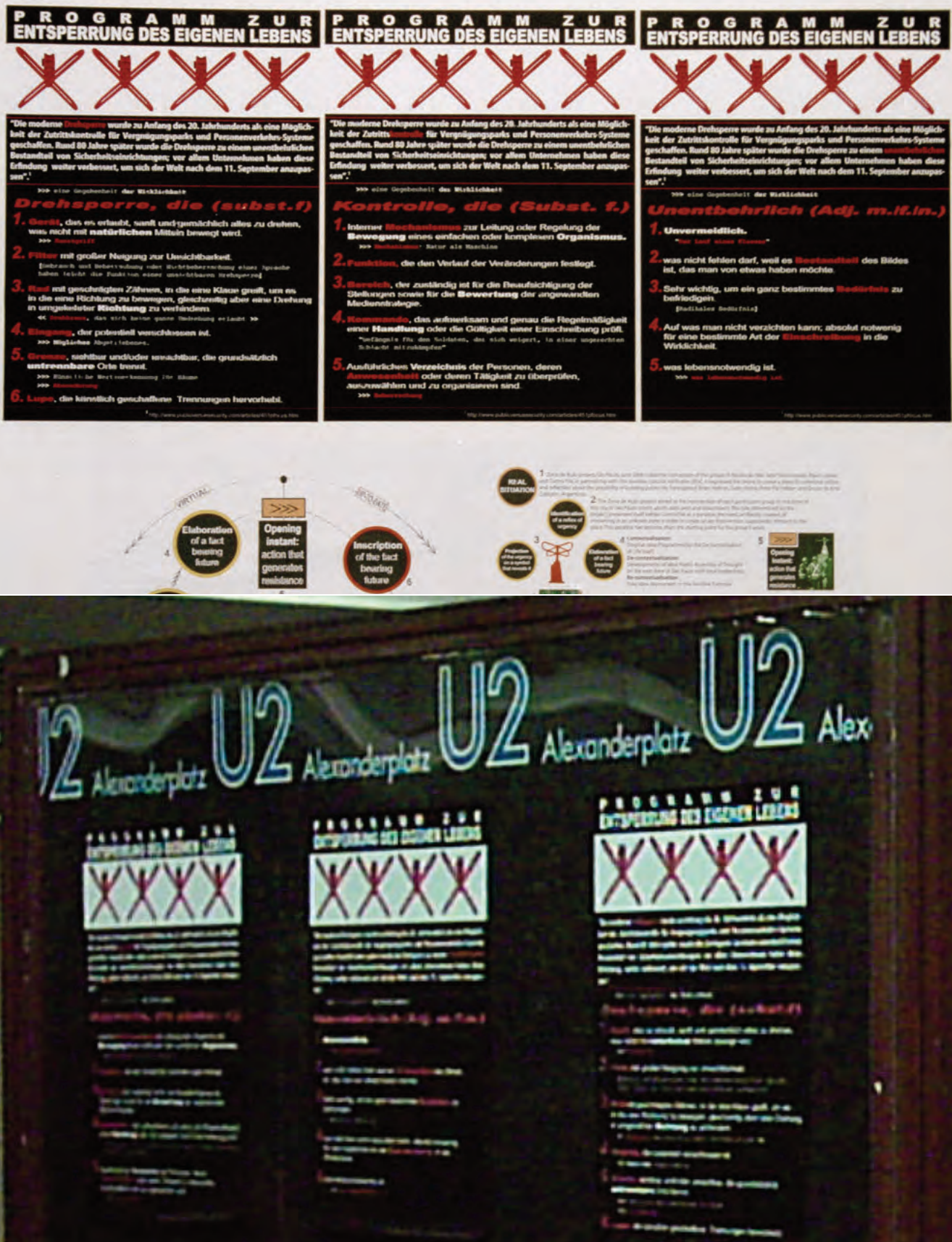

Cartazes do "Programa para Descatracalização da Própria Vida", realizados

pelo Contrafilé em ocasião de sua participação na exposição "Collective Criativity",

Fridericianum Museum, Kassel/Alemanha, 2005. 


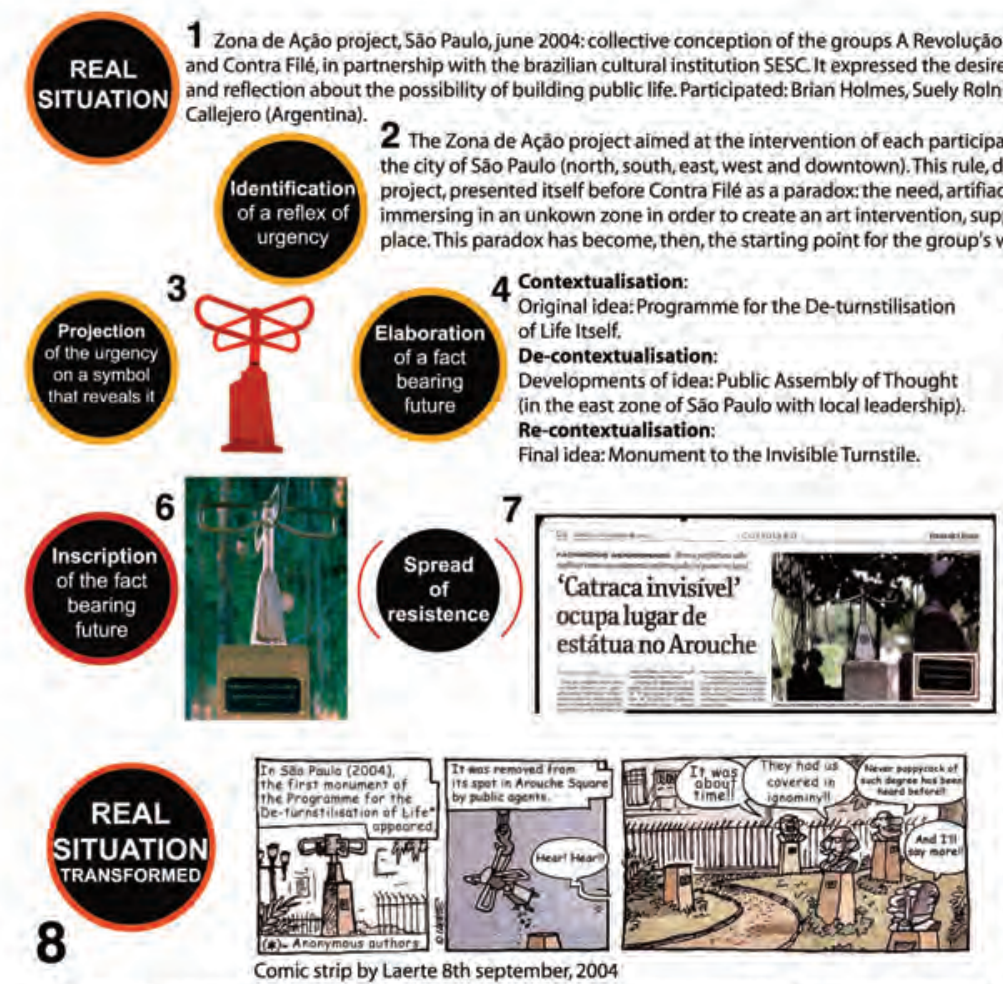

FUVEST(Sáo Paulo University Admission Examinations Board) uses Programme for the De-turnstilisation of Life Itself as theme for composition: "(...) Everything indicates, therefore, that the group responsible for this programme believes that there is an excess of control, of various types, exerted over the bodies and minds of people, submitting them to constant limitations and constraints, In view of the group's motivations, do you consider that the programme by them developed is justified?".9th january, 2005.

"Trick question in Fuvest" "This time the Fuvest examination board has exceeded itself. The day before yesterday, they imposed as the theme for the examination's composition a short essay around the theme of the "Programme for the De-turnstilisation of Life". (..) Nothing against the sympathetic anarchy of the group "Contra File", on the contrary. The problem is the reheated spirit of '68' that animates examiners at Sảo Paulo University (...) What did they intend, really, those examiners? That the applicants wrote on Marcuse's "one-dimensional man"? That they discussed Foucault's "Microphysics of Power"? That they produced an apologia of the Good Savage? Frankly... one feels like being a little rude: ask someone who lives in the distant peripheral neighbourhood of Guaianazes what he or she thinks of the de-turnstilisation of the packed bus..." Fernando Barros e Silva (journalist and critic of Folha de São Paulo newspaper). 11 th january, 2005.

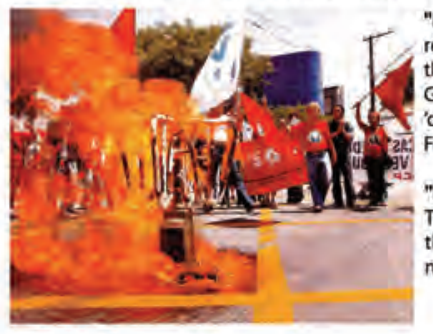

"FUVEST composition" "(..) What the examining board intended with the proposed theme? To receive well written texts, but devoid of any preciousness or academicjargon. Texts that would tackle a theme relevant to us all (...) differently from what the journalist has recorded in his text, applicants from Guainazes also think, reflect and go for it! They do not limit themselves to be solely concerned with the 'de-tunstilisation of the packed bus:" Maria Thereza Fraga Rocco, vice-director of USP Admission Board, Folha de Săo Paulo newspaper, 17 th january, 2005.

"FIRE ON THE TURNSTILE" "Demonstrators set a turnstile alight before invading the fuvest building. The theme for the admission examinations' composition was the 'de-turnstilisation of life'; they criticise the compulsory fee to be paid in order to take the examinations."Lead in Folha de Săo Paulo newspaper, 11th february, 2005.

Diagramas feitos pelo Contrafilé com o intuito de refletir sobre o que sucedeu no "Programa para Destracalização da Própria Vida". 


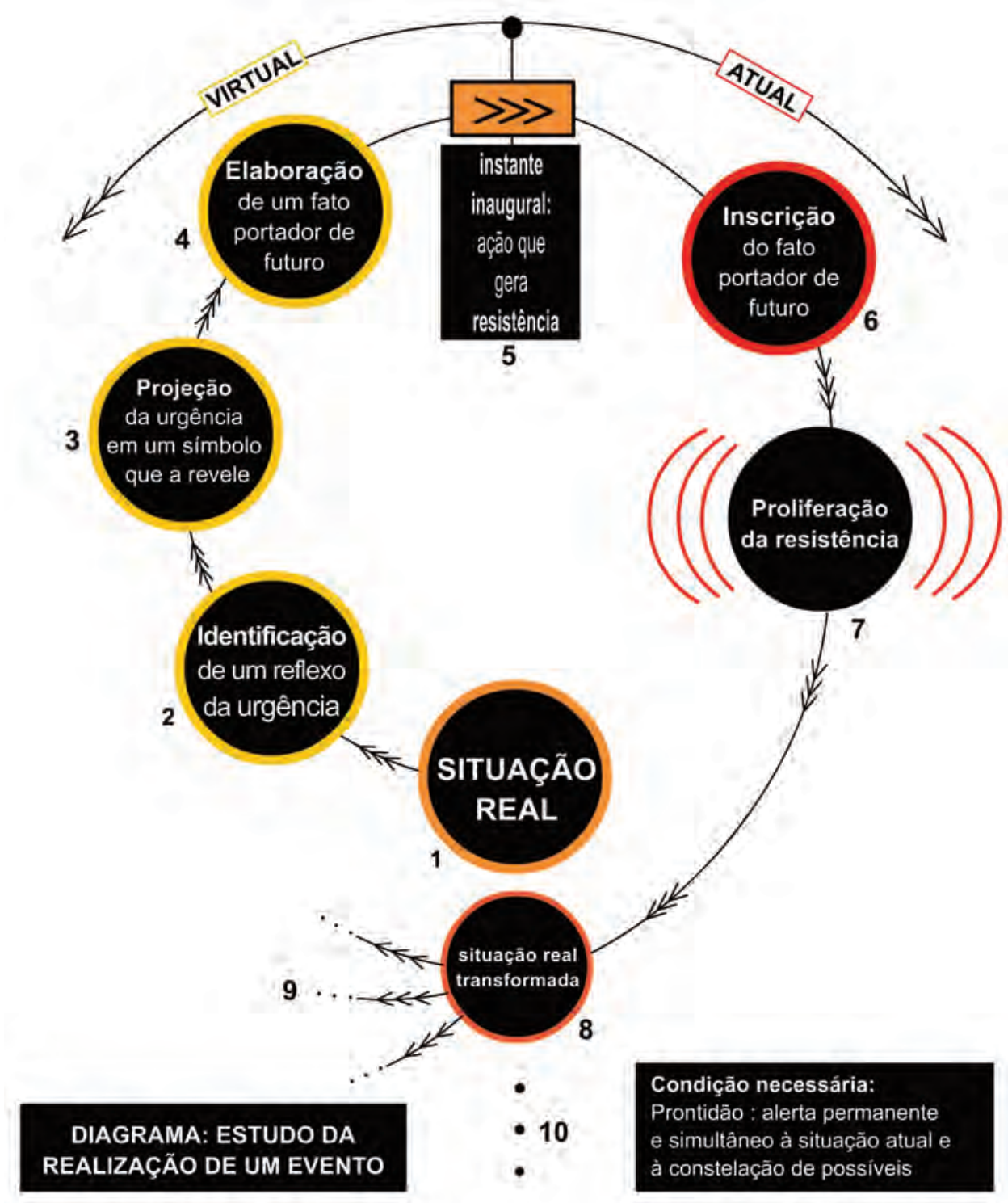



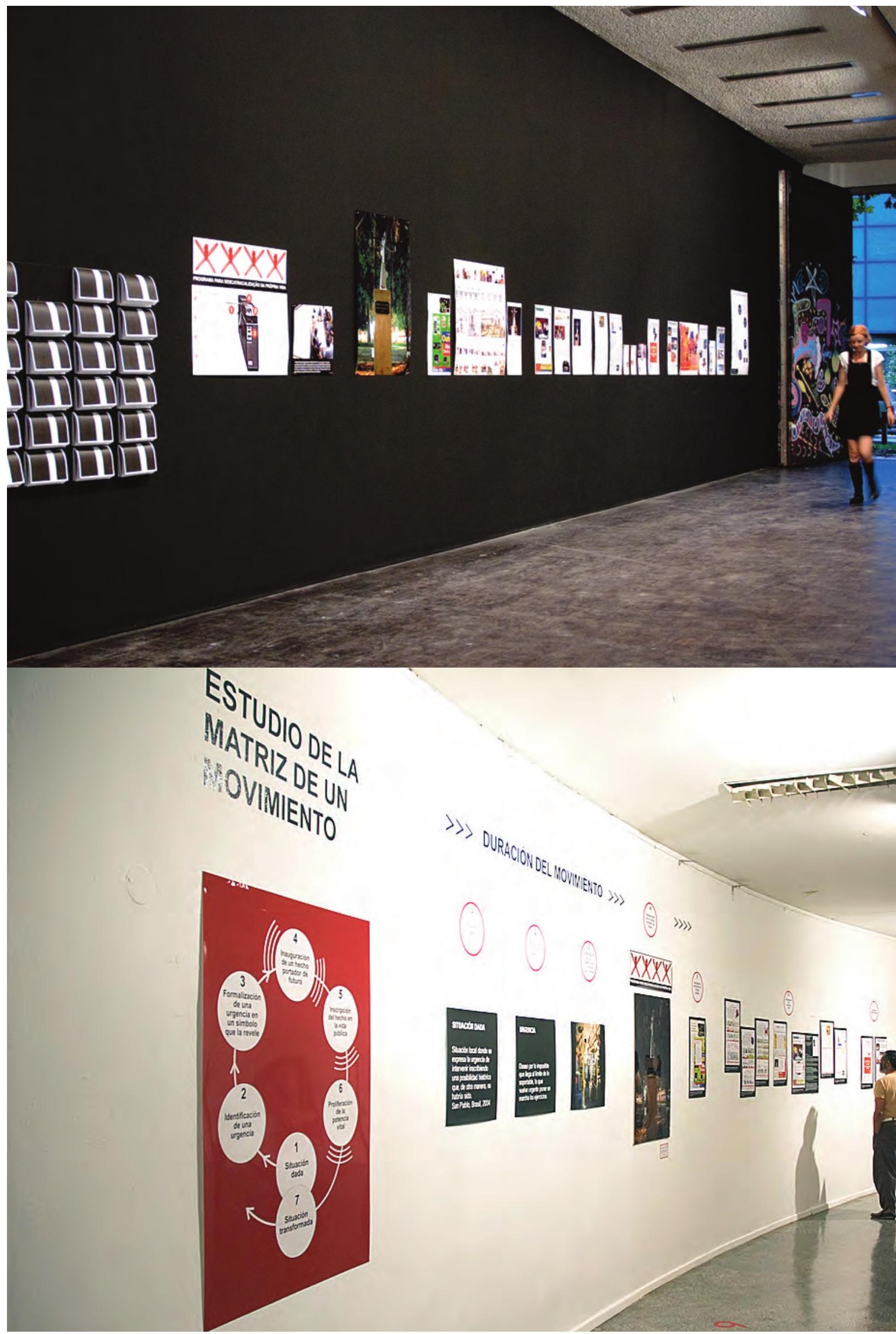


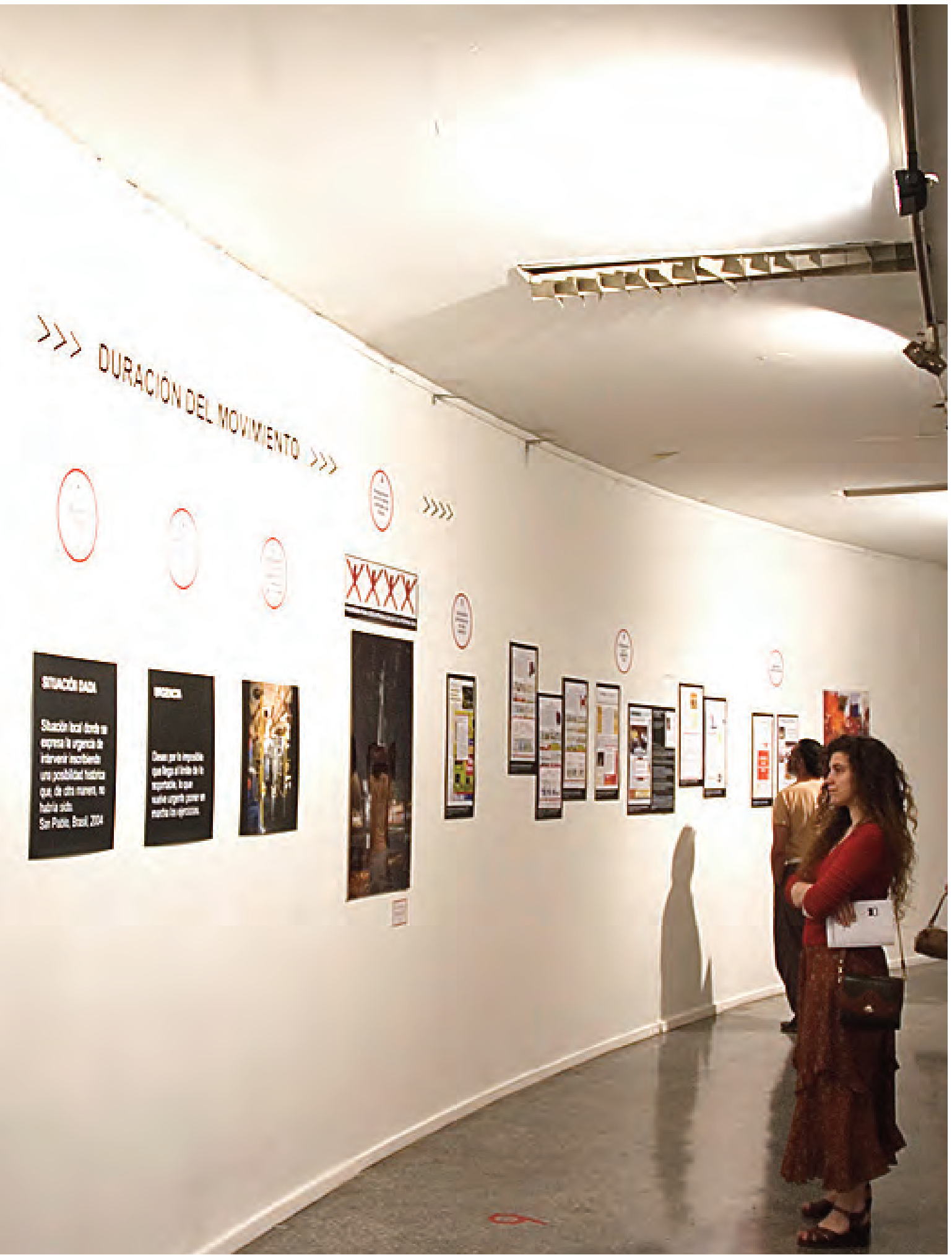

"Programa para Descatracalização da Própria Vida" apresentado como obra-sistematização de um processo em diferentes exposições ao redor do mundo: Collective Criativity (Alemanha/Kassel, 2005), La Normalidad (Buenos Aires/Argentina, 2006) e If you See Something, Say Something (Sidney/Austrália, 2007). 
em um acontecimento efetivo.

Há também diversos movimentos de abertura e síntese que perpassam o trabalho e nos levam a pensar em como uma inscrição inicial vai gerando outras inscriçôes e discursos: uma conversa inicial com referentes da Zona Leste que produziu uma primeira síntese (o Monumento), que foi inscrita na cidade e levou a um transbordamento e a uma agitação de sensibilidades gerando novos fatos, o que mobilizou uma nova síntese grupal (a sistematização pelo Contrafilé dos discursos decorrentes da instalação do "Monumento à Catraca..." e o diagrama feito pelo grupo).

Este movimento pode ser compreendido como a constituição da imagem de uma "microssociologia" que, como diz Tiago Seixas Themudo a respeito da forma de pensá-la, proposta por Gabriel Tarde, acontece nos "pequenos e praticamente impercep" tíveis formigamentos do social" e nos quais "está o germe de toda grande transformação, tal como uma pequena pedra atirada em um lago, cujas ondas produzidas a partir de um ponto singular podem se propagar por toda a extensão do lago, ou como uma epidemia mais ou menos intensa" (Themudo, 2002, p. 9). 
CAPÍTULO III

\section{Pensando a crítica}




\section{Justaposição e instituição}

A partir da tentativa de definir a cidade contemporânea como um lugar de disputa dos sentidos das leis e das normas, é possível entender as manifestações artísticas e as suas representações situadas, não fazendo um papel de simuladores no embate, mas sendo de fato peças fundamentais dele. Isso se dá em um contexto no qual, ao colocar a força de criação em constante produção de mundos virtuais e paradisíacos, como os veiculados pelo marketing, o capitalismo avançado gera um modo de subjetivação alienado em relação ao outro e ao espaço público.

\section{[...] No caso específico do neoliberalismo, a estratégia de subjeti- vação, de relação com o outro e de criação cultural adquire uma importância essencial, pois ganha um papel central no próprio princípio que rege o capitalismo em sua versão contemporânea. É que é, fundamentalmente, das forças subjetivas, especialmente as de conhecimento e criação, que este regime se alimenta, a ponto de ter sido qualificado mais recentemente como "capitalismo cogni- tivo" ou "cultural" (Rolnik, 2006, p.4).}

Face à urgência de enfrentar essa política de subjetivação instalada pelo neoliberalismo, que utiliza e celebra a criatividade como uma estratégia central para a concentração de poder (id. ibid.) e, portanto, de encolhimento do domínio do público, as manifestações artísticas coletivas aqui tratadas buscam criar novas formas de construir as representações, que partem da escala da cidade e voltam a ela.

No início, sem ter conhecimento uns dos outros, depois, aos poucos, criando redes virtuais e presenciais - o que de fato começa 
a acontecer quando os grupos passam a se encontrar em exposiçôes e seminários nacionais e internacionais ${ }^{84}$, os coletivos artísticos $\mathrm{de}^{-}$ senvolvem, a partir de conflitos concretos e múltiplos e de estratégias e lutas singulares, uma sensibilidade e uma forma de pensar a cidade e a realidade. É a partir da singularidade das lutas e do modo de compreendê-las que se torna possível vislumbrar a existência de uma luta comum.

Essa forma de produção do comum se dá pela invenção de estratégias de resistência que, apesar de baseadas em problemáticas locais, formam redes, ainda assim correndo o risco de se despotencializarem pela fragmentação. Estas redes, que levam e trazem informações, e hoje já estão instauradas, produzem uma contaminação mútua de conteúdos, conceitos, estratégias e métodos que desafiam tanto os discursos socialmente hegemônicos quanto os processos que levam à sua produção.

Nesse sentido, se estamos aqui entendendo a produção do comum por meio de lutas produzidas por e produtoras de singularidades, é interessante atentarmos, por outro lado, para a constante preocupação de Henri Lefebvre, já na década de I970, com a redefinição de referenciais, que se explica diante de uma história em que a fragmentação cada vez mais se aprofunda e expande por todas as dimensões da vida. Segundo Lefebvre, isso seria parte de uma estratégia do poder através da qual, para homogeneizar e hierarquizar

84. Alguns exemplos de eventos que tiveram participação de coletivos paulistas: "Seminário Máquinas" (intercâmbio com participantes de grupos de arte política, práticas artísticas colaborativas e cooperativas, coletivos políticos criativos de diversos lugares em dois continentes), a convite de Marcelo Expósito, do Museu d'Art Contemporani de Barcelona (Macba), Barcelona, Espanha, 2007; Exposição "La Normalidad/Ex-Argentina" (última etapa do projeto Ex-Argentina, iniciado em 2002, que reuniu coletivos artísticos de diferentes partes do mundo como Europa, América Latina, Leste Europeu para expor seus trabalhos e refletir coletivamente sobre o conjunto de tensões ocultas que transformam um sistema econômico em uma máquina de desigualdade), curadoria de Alice Creischer e Andreas Siekmann e coordenação do coletivo argentino Etcétera no Museu Palais de Glace, Buenos Aires, Argentina, 2006; exposição "Collective Creativity" no Kunsthalle Fridericianum Museum, curadoria do coletivo Croata WHW, Kassel, Alemanha, 2005. Em texto presente no catálogo da exposição, o coletivo-curador WHW dizia: "A exposição abrange diferentes aspectos emancipatórios do trabalho coletivo, onde a criatividade colaborativa não é apenas uma forma de resistência ao sistema dominante de arte e à convocação capitalista para a especialização, mas também uma crítica produtiva e performática". 
a vida, esta primeiro é fraturada, dividida, através da violência exercida pelo capitalismo de Estado, nos tempos e espaços cada vez mais instrumentalizados a seu favor.

Lefebvre, na época, identificava a necessidade de construção de sentidos comuns para a produção social, sem que para isso fosse necessário pressupor fins fixos e atualmente representados, o que levaria a cair em uma forma teológica ou teleológica de pensar e agir frente à história. Assim, o autor refletia sobre os possíveis caminhos para que o "comum" pudesse ser construído e se tornasse um referencial, sem se transformar numa camisa-de-força, no "fim" da história enquanto término, mas num "fim" enquanto construção de sentido, necessário, de acordo com ele.

Se a estratégia do poder, de fragmentar a vida, produz a falta de sentido sobre a qual se refere Lefebvre, este autor reconhece também que, na busca de novas referências que não são ou apontam para verdades absolutas, estão implicadas as categorias do devir e do possível-impossivel como análise das diferenças. Segundo ele, em meio à crise, seria necessário atentar para a noção de desenvolvimento desigual introduzida por Lênin, que distinguia crescimento econômico de desenvolvimento social, evidenciando o fato de que a crise gera diferentes processos e respostas nas diferentes sociedades. Conhecendo o que difere, é possível, para Lefebvre, compreender o virtual e não apenas o atual e, então, sair de uma lógica puramente racional e hegemônica.

No entanto, essas virtualidades contidas no processo de diferenciação não interessam ao sistema dominante. Por isso, muitas vezes são reduzidas aos particularismos, que não seriam ainda diferenças, segundo o autor, mas fatos naturais transformados em traços de distinção de uma classe ou grupo, não conseguindo superar a frag- 
mentação decorrente da fratura do real pelo poder. As particularidades só podem se tornar diferenças, na visão de Lefebvre, quando estão em relação e podem assim travar, a partir da luta de morte ${ }^{85}$, um embate para se afirmar enquanto qualidades irredutiveis. Assim, a naturalização da história e sua homogeneização podem vir a ser superadas através da luta pela construção de espaços diferenciais, nos quais o residual ganha força atuando para transformar a história.

A questão que, a partir daí, se coloca para o autor, é a de saber como essa dimensão residual ganha potência suficiente para se transformar em luta de morte, adquirindo a dimensão de projeto, na dialética entre denúncia e anúncio, sempre relembrada por ele. $\mathrm{E}$ também a de saber como as diferenças se reúnem, compondo "campos diferenciais" capazes, de fato, de intervir e se inscrever como realidade no espaço social.

A produção do espaço não seria 'dominante' no modo de produção, mas religaria os aspectos da prática coordenando-os, reunindoos numa prática, precisamente. [...] O conceito de espaço religa o mental e o cultural, o social e o bistórico. [...] Isso evolutivamente, geneticamente (com uma gênese), mas segundo uma lógica: a forma geral da simultaneidade; pois todo dispositivo espacial repousa sobre a justaposição, na inteligência e sobre a reuniāo material, de elementos sobre os quais se produz a simultaneidade (Lefebvre, I98I, p. 2).

A "justaposição" e "simultaneidade" características do dispositivo espacial, segundo Lefebvre, assim como o "jogo situado de escalas”, ideia desenvolvida por Ananya Roy, são conceitos que tentam expressar por que o espaço e, mais precisamente, o urbano, deve 
ser compreendido como uma forma transversal capaz de superar a fragmentação. E, por isso, como campo de forças apropriado para pensar o social e um lugar cada vez mais contundente para o enfrentamento político contemporâneo - o que nos leva a uma necessidade de aprofundamento da reflexão.

Se estamos entendendo a produção do espaço como uma disputa travada a partir de "situações de indeterminação" materializadas no urbano, nas quais diversas soberanias inscrevem uma multiplicidade de tempos, espaços, formas, etc., que acabam por compor uma "luta comum", e se já refletimos um pouco sobre como essa "comunidade" enfrenta a presença institucional no espaço urbano, seria também pertinente discutir como isso acontece em relação aos "espaços institucionalizados da cultura e da arte" e, por sua vez, que tipo de "crítica institucional" é gerada por essas práticas urbanas, a partir da relação entre o espaço diferencial e o vislumbre de instauração de um espaço compartilhado, mesmo no interior das Instituições. Ou seja, como as práticas e manifestações urbanas lidam com as divisões, fragmentações, fraturas, promovidas pelo "sistema da arte", encontrando caminhos no meio disso para a constituição de um corpo crítico que tenha alguma potência de inscrição sociocultural e de reverberação.

Não pretendo lançar aqui um falso problema ou cair na repetição de reflexôes que já têm sido feitas por diversos pensadores em relação à forma como a "crítica institucional" é exercida hoje; gostaria somente de tentar criar relaçôes entre a cidade como espaço de diversas soberanias em disputa e o espaço institucional artístico e cultural. Acredito que esse exercício possa ajudar a ampliar o olhar sobre o que seria o "marco do urbano" nas manifestaçôes artísticas aqui analisadas. 
Apesar dos espaços institucionalizados, dentre eles os ligados às artes e à cultura, tais como museus, galerias e espaços culturais, serem muitas vezes reconhecidos, no embate, como lugares privilegiados de "encenação de uma sociabilidade fictícia" (Arantes, I991, p. I67), de massificação e difusão da experiência como bem de consumo, a participação de diversos coletivos de diferentes nacionalidades em uma série de exposições ao redor do mundo, evidencia um movimento de idas e vindas no campo institucional da Arte (Rolnik, 2007). Isso demonstra que diversas práticas que se propõem uma construção crítica e têm a convicção de que a produção artística não existe fora de seu contexto social, encaram o campo institucional como um "espaço de disputa" e não como um "espaço apartado da vida".

Portanto, nessas práticas, estar em relação com a "instituição artística e cultural" é também poder entender que o "espaço e a vida pública" não são sinônimos de "estar fora", assim como "estar dentro" não significa a ausência da possibilidade do embate. Disputar todo e qualquer espaço permite discutir a escala institucional estando nela e não como negação a ela, problematizando assim as formas de representação no mundo contemporâneo, quem pode representar e quem é representado.

Mesmo com as transformações ocorridas na crítica institucional, ainda se faz necessário observar e refletir sobre os "porquês" dos momentos de deriva dos artistas e coletivos do circuito oficial para os interstícios mais tensos da cidade - já que este pode ser um sintoma da recusa em aceitarem a relação entre capital e cultura presente hoje no terreno da arte, sendo a vida urbana e a vida pública justamente o lugar onde deságua a força de criação instrumentalizada pelo mercado (Rolnik, 2007). 


\section{Repensando a crítica}

A partir desses questionamentos tanto em relação à cidade quanto ao espaço institucional como espaços de disputa por excelência, nos quais a produção de subjetividade e de vida pública se dá de forma totalmente imbricada, é interessante compreender como se atualizam algumas problemáticas colocadas desde a modernidade. Delinear brevemente o desenvolvimento de algumas questóes, como a "autonomia da arte" e sua relação crítica com a institucionalização, pode nos ajudar a tornar mais claro o que estamos entendendo efetivamente como uma prática crítica e como, quando e onde a arte como prática crítica acontece hoje - tendo em vista o processo de modernização capitalista radicalizado pelo neoliberalismo.

Antes de lançarmos o olhar mais profundamente sobre a situação contemporânea, esboçaremos uma tentativa de observar como a tensão entre a produção de subjetividade e de vida pública se configurou no modernismo e, depois, na passagem para o chamado "pósmodernismo", para refletirmos sobre o que, desta tensão, permanece como "devir" na contemporaneidade, impulsionando as práticas artísticas atuais.

Segundo Andreas Huyssen, que escreve sobre a passagem da modernidade para a pós-modernidade, a consciência das limitações do modernismo, que evidencia a impossibilidade de seguir acreditando na emancipação da vida através da cultura, teria levado algumas correntes pós-modernas a uma radicalização de proposições, conhecidas desde o modernismo, como o esteticismo e a idéia de "morte do sujeito", que desembocaria na perda de importância da autoria ${ }^{86}$.

Há aí o reconhecimento, no contexto a partir do qual escreve esse autor (Estados Unidos da década de 1980), de que muitas ope-

86. Já Fredric Jameson, para quem a "morte do sujeito" é antes um sintoma da pósmodernidade do que da modernidade, destaca sobretudo a sensação de que tudo já foi feito e de que, portanto, não seria possível ou relevante tentar encontrar formas de representação de uma experiência singular do presente (Jameson, 1985). 
rações antes consideradas como posições radicais, deixam de sê-lo na medida em que o capitalismo pós-industrial avança. $\mathrm{O}$ esteticismo, porque seria difícil sustentar a sua função contestadora numa era da estética da mercadoria. E a proclamação da morte do sujeito, porque ela meramente duplica, no nível da estética e da teoria, o que o capitalismo, como um sistema de relaçôes de troca, produz tendencialmente na vida cotidiana: a negação da subjetividade no próprio processo de sua construção (Huyssen, I99I). Portanto, é fundamental entender quando, nesse processo de constante embate entre constituição do sujeito e da vida pública, iniciado na modernidade, se afirmam posiçôes emancipadoras e críticas e quando, ao contrário, se afirmam posiçôes que, embora aparentemente progressistas, são conservadoras.

Analisando o catálogo da "Documenta 7 de Kassel" (realizada em I982), Huyssen nos dá um exemplo de como este esvaziamento crítico se manifesta no pensamento do curador Rudi Fuchs. Em trechos da introdução escrita por Fuchs, Huyssen diagnostica passagens nas quais o curador demonstra a preocupação em recuperar uma certa "pureza" da arte, para isso referindo-se tanto ao artista - "[...] afinal, o artista é um dos últimos praticantes da distinção individual” -, quanto ao Museu - "[...] um espaço além daquelas infelizes 'diversas pressões e perversóes sociais' que a arte tem tido de enfrentar". Neste caso, Huyssen atribui o abandono da consciência crítica do modernismo, ao próprio arranjo do espaço como "encenação de uma convicção", a da possibilidade de existência da contemplação pura (Huyssen, I991).

Ora, se invocamos o artigo "Museu, Valery, Proust" de Theodor Adorno (I997), podemos perceber o surgimento deste lugar de contemplação na modernidade como extremamente problemático. 
Se, por um lado, o Museu foi, então, fundamental para assegurar o lugar da contemplação na criação de uma heterotopia - diante da expansão de uma vida eminentemente burguesa, citadina, com os seus tempos e espaços permeados pelo consumo -, por outro, levou ao que o autor denomina de uma "neutralização da cultura". Esta aporia proclamada por Adorno é, para ele, absolutamente necessária para a produção de uma postura crítica diante da arte. Ou seja, se o Museu é, sim, um espaço que distancia a arte da vida, é, também, por instaurar a utopia do espaço público moderno por excelência, o que possibilita que a experiência solitária da obra encerre um impulso emancipatório de evidente consequência social (Arantes, I99I, p.I63).

Adorno constrói seu argumento trazendo à tona diferenças e semelhanças entre as concepções de Valery e Proust em relação à contemplação vivida nos Museus, com isso buscando mostrar como, na emergência de uma esfera pública burguesa, a crítica social efetivamente acontece no embate entre o sujeito e a obra de arte. Segundo Adorno, enquanto Proust dá ênfase à memória adormecida do observador, na qual a obra de arte perde a sua materialidade no contato com o fluir da subjetividade - que para ele é o que dá sobrevida à vida póstuma das obras, "naquilo que nas grandes obras é mais do que mera cultura" -; Valery desenvolve um olhar no qual a obra, sua autonomia, suas relaçóes internas, seriam o ponto de partida e chegada, sendo o sujeito diante da imanência da arte, uma mera contingência. Se para Proust, a morte das obras desperta-as para a vida - a partir da relação com o homem -, sendo o Museu o espaço público que possibilita a difusão desta relação -, para Valery, esse tipo de circulação, que acumula e sobrepõe obras, é um ato de barbárie contra o caráter sagrado da cultura.

Otília Arantes, em seu texto "Os Novos Museus” afirma que, 
para Adorno:

A neutralização da cultura transpareceria assim com maior intensidade nos museus. Mas não seria uma razão para fechá-losdiz Adorno. As ambiguidades do museu são as da própria arte moderna e da relação que ela mantém com o seu público. A alternativa oposta - repor as obras no seu lugar de origem - culminaria quando muito no kitsch e na mise en scène, sendo ainda mais prejudicial. Mas não é menos verdade, observa Adorno, que se renunciarmos à possibilidade de reinserir a obra numa tradição, cometeremos igualmente um ato de barbárie por excesso de fidelidade à cultura (I991, p. I62).

Walter Benjamin, segundo a autora, aborda a questão dos bens culturais e do processo de transmissão com que eles passam de uns a outros, como claramente originados em atos de barbárie e horror:

Como era de costume, a pilhagem é arrastada junto no cortejo triunfal. Costuma-se chamá-la de: bens culturais. No materialista histórico, eles terão de contar com um observador distanciado. Pois tudo o que ele consegue perceber em termos de bens culturais, tudo, sem exceção, tem uma origem que ele não pode rememorar sem horror. Eles devem a sua existência não só aos esforços dos grandes gênios que os produziram, mas também à anônima servidão dos seus contemporâneos [...] (Benjamin, I99I, p. I57).

Por isso, a "distração esclarecida" seria, para Benjamin, uma forma de não privar a coletividade de transformar-se em sujeito da cultura. Diminuir a distância entre obra e espectador e entre espec- 
tadores entre si - possibilidade primeiro dada pelo cinema, com o seu potencial de "recepção coletiva" -, libertaria a cognição dos "domínios confinados da cultura afirmativa" (Arantes, I99I, p. I63).

Retomando essa complexidade presente no debate moderno, sobre a relação entre a arte e sua institucionalização, talvez se torne mais clara a interpretação feita por Andreas Huyssen do pensamento curatorial de Fuchs na "Documenta 7 " como redutor da teoria crítica da/na modernidade ao privilegiar um dos termos do paradoxo (a possibilidade de uma contemplação livre das tensões sociais), como se isso representasse um retorno à tradição modernista. Trata-se de uma redução que evidencia que não é a modernidade e o modernismo que se tornam obsoletos. Ao contrário, este tipo de aplicação das codificações da crítica modernista de forma totalizante e domesticada, é uma estratégia destinada a enterrar críticas políticas e estéticas de certas formas de modernismo (Huyssen, 199I).

Poderíamos arriscar concluir que somente um movimento de compreensão crítica das dissincronias presentes no interior do modernismo, atualizaria a tarefa de encontrar possibilidades críticas mais interessantes na arte contemporânea ao criar um campo de forças mais amplo para tal discussão, avançando em relação às:

\section{[...] ideias familiares sobre o que constitui uma arte crítica (nega- tividade, vanguardismo, arte engajada, recusa da representação, realismo crítico, abstração) que tem perdido muito de sua força explicativa e normativa (id. ibid., p.2I).}

Sendo assim, se Huyssen considera legítima a preocupação de diversos pensadores ${ }^{87}$ de resguardar o caráter emancipatório do Projeto Moderno, discorda da visão de que à chamada pós-moder- 
nidade, como "conjunto", seria intrínseca uma postura neoconservadora já que, segundo ele, diversas linhas do pós-modernismo não abrem mão do pensamento crítico presente no modernismo, mas sim da visão heróica da cultura moderna. $\mathrm{O}$ que significa admitir uma mudança de condições históricas que tornou possível a emergência da problemática da alteridade de forma mais contundente na arte contemporânea, contrapondo-se ao caráter imperialista da cultura da modernidade (Huyssen, I99I).

Diante dessas questões, como pensar a relação entre arte, artista, públicos e sistema da arte no mundo contemporâneo, produzindo, a partir daí, uma atualização da complexidade do pensamento crítico após mais de vinte anos da queda do muro de Berlim, vinte e sete anos do fim da ditadura militar no Brasil, trinta anos de neoliberalismo mundial, agora plenamente instaurado? Pois, se vemos, por um lado, um processo de esvaziamento da noção do que vem a ser "público", de acirramento das diferenças socioeconômicas, de criminalização dos movimentos sociais; por outro, vemos o surgimento e desenvolvimento de práticas e manifestaçóes que buscam inscrever uma discussão sobre a possibilidade ou não de produção compartilhada de outros imaginários.

O fato de repensar e apropriar-se do espaço público, tanto material, quanto simbolicamente, criando outras possibilidades de vivenciar a cidade, a partir do momento em que as próprias repre-

87. Juergen Habermas, que prolonga as teses da escola de Frankfurt e um dos mais importantes defensores do modernismo, foi dos primeiros pensadores a colocar a relação entre pós-modernismo e neoconservadorismo de uma forma histórica e teoricamente complexa. Habermas (1992) contesta os argumentos que acusam o modernismo cultural de ser responsável pelos males da sociedade, afirmando que, na verdade, é a modernização econômica e social que causa a alienação, que ele entende como uma "colonização do mundo da vida" pela economia. A preocupação central deste pensador foi a de proteger o potencial emancipador da razão esclarecida que, para ele, seria o sine qua non da democracia política, em um momento de mudança de tendência em que havia um recrudescimento conservador em distintas partes do mundo. Neste sentido, interpreta a virada cultural à luz da virada de tendência política, compreendendo o pós-modernismo como evidência, sobretudo, de uma ruptura com o projeto moderno de emancipação. Ao conferir ao pós-modernismo o atributo de "neoconservador", a preocupação de Habermas era, sobretudo, a de que a revolta contra a razão iluminista se tornasse, em última instância, reacionária, uma visão politicamente perigosa e limitada - e relembra Aushwitz como resultado não de um excesso de razão iluminista, mas de um impulso anti-modernista e antiiluminista, que teria se valido cruelmente da modernidade para os seus propósitos. 
sentações são questionadas - de si, do outro e dos próprios espaços -, é o que define, para Vera Pallamin, uma prática que, hoje, tem um caráter crítico. Como diz ela, delimitando o que seria uma "prática crítica" no campo de análise de práticas artísticas urbanas:

\begin{abstract}
Destacamos a arte urbana como prática crítica exatamente nesse momento em que o borizonte não possui mais a carga utópica que já teve um dia. [...] potencializada pela idéia de tornar a cidade disponível para todos os grupos, essa prática crítica inclui dentre seus propósitos estéticos o desafio a certos códigos de representação dominantes, a introdução de novas falas e a redefinição de valores como abertura de outras possibilidades de apropriação e usufruto dos espaços urbanos físicos e simbólicos (2002, p.IO7).
\end{abstract}

$\mathrm{Na}$ medida em que diversas instituições de todo o mundo estão repensando a sua função social e política e como se relacionar com questôes contemporâneas, é interessante ler o site do Museo Reina Sofía, no qual fica bem claro este interesse de um gestor (o diretor Manuel J. Borja-Villel) em contribuir para que o fato de estar no museu se torne uma questão significativa e complexa. Borja-Villel faz isso ao introduzir no próprio espaço institucional o que antes eram questôes pensadas predominantemente por artistas e movimentos artísticos que afirmavam estar "fora" dele:

O programa do Museo Reina Sofía se baseia em uma redefinição da função do museu alternativa aos modelos históricos dessa instituição. Concebido como um lugar gerador de espaços intersticiais de sociabilidade e discussão na esfera pública, propõe modelos de resistência em uma sociedade na qual são primordiais o con- 
sumo e a mercadoria e em que a produção se fragmentou ocasionando um mapa geopolítico inédito assim como novas classes sociais, relações e subjetividades. A criação de narrativas alternativas, de novas formas de intermediação e a formação de um espectador ativo são linhas de força do Museu. O Museu contesta a dinâmica centro-periferia e a visão univoca da história da arte. Essa deixou de ser escrita como se estivesse constituída por grandes continentes para ser uma espécie de arquipélago no qual emergem diversas relaçôes em uma cartografia cambiante. As outras modernidades, antes subalternas, alcançam aqui a sua dimensão mais complexa e artistas antes considerados derivativos ou secundários cobram voz, desafiando, graças a novos vínculos de solidariedade entre o intelectual e os coletivos, as regras estabelecidas a partir do mundo europeu ocidental..$^{88}$

Neste processo constante e interminável de redefinição da relação entre arte e sociedade, o que diferentes pensadores e artistas parecem buscar são as transformaçôes qualitativas que se operam no potencial crítico da cultura. Potencial que hoje não estaria mais atrelado à uma noção de resistência como forma de superar sua simples oposição à afirmação, em termos de negatividade ou não-identidade, já que a própria resistência deve ser sempre pensada como "específica e contingente ao campo cultural em que opera" (Huyssen, I99I, p.79).

88. Trecho da Missão do Museo Reina Sofía, escrito por seu diretor, Manuel J. Borja-Villel. Texto presente no site deste museu, link: http://www.museoreinasofia.es/museo/mision.html. Acessado em maio de 2011. 


\section{Performatizar a crítica}

Pouco tempo depois de ter feito o trabalho "Não estamos em Rebeliáo...”, o coletivo MICO foi convidado pelos curadores do "Panorama da Arte Brasileira 20or", Ricardo Basbaum, Paulo Reis e Ricardo Resende, para realizar um trabalho no livro-obra que seria produzido como parte da exposição. A curadoria da mostra se centrava no "[...] mapeamento de espaços alternativos, cooperativas e colaborações entre artistas, organizações e trabalhos surgidos nas comunidades em paralelo à cena institucional - museus, centros culturais, galerias - existentes e ativos em diferentes regióes do país" (Mesquita, 200I, p.5).

Texto do MICO para o catálogo do "Panorama da Arte Brasileira 200I":

O grupo tem como objetivo criar um espaço para as pessoas vivenciarem a cidade de uma forma diferente da qual estão acostumadas, podendo, assim, se distanciar e refletir sobre ela. Às vezes, um instante faz com que repensemos todo o universo. Deslocando coisas na cidade e da cidade, buscamos produzir este efeito, minimo, ainda em construção, mas que pode se transformar em uma reflexão e talvez em uma nova ação. Vivemos na cidade e temos a certeza de que ela não precisaria ser encarada como um espaço inexoravelmente condenado à degradação. Isso não é real quando percebemos que depende de nós, de nossa ação, que ela se restabeleça enquanto um espaço para a vida. O trabalho em grupo, diferente da prática artística in- 
dividual, tem como principal característica a possibilidade da troca com outras pessoas, outras idéias, outros olhares. É incrivel que numa cidade tão dispersiva quanto a nossa consigamos nos encontrar sempre, não com uma finalidade utilitária, mas artística, política, reflexiva.

A reflexão sobre o nosso lugar - que se constitui a partir deste lugar - ajuda a construir o espaço público, o diálogo.Assim, também aparecem muitas questões que dizem respeito ao genérico, ao mundo, às indignações e esperanças que nos movem, aos fatos que nos aterrorizam. Uma coisa é refletir abstratamente sobre tudo isso. Outra é agir a partir daquilo que temos perto, dos fatos do nosso cotidiano, daquilo que está diante dos nossos olhos, para dai chegar às grandes questões. Mergulhando na localidade é que se chega aos grandes temas da atualidade - já que a localidade em suas múltiplas determinações é, em si, o atual. [...] 2uando estranhamos o nosso lugar, ele se evidencia e se torna novamente vivo, rico em questões. Assim, ele vai se tornando novamente nosso.

Em relação ao sistema de arte, acreditamos que não é necessário ser artista para se comunicar artisticamente. Depender de um sistema de arte para se comunicar com o mundo significa restringir a sua proposta a um grupo de pessoas determinado. Entendemos a arte fora daqueles espaços destinados e fixxos; a cidade participando organicamente da arte, mas näo como mais uma galeria. 


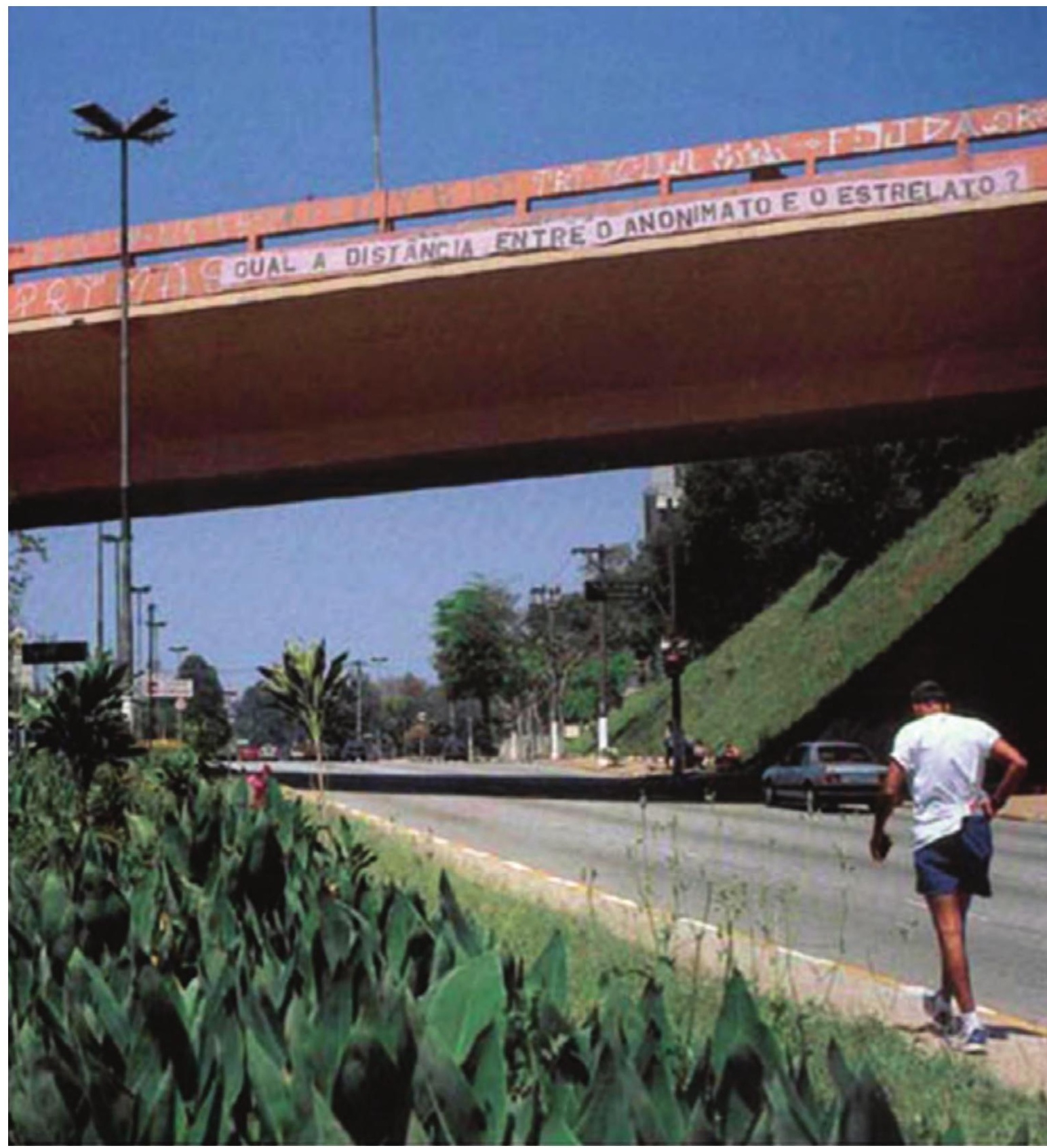

O grupo se apropriou de uma matéria de jornal sobre o Panorama, colocada ao lado do anúncio de um show de rock, com um slogan que dizia "Qual a distância entre o anonimato e o estrelato?". Usou o acaso a seu favor e só a partir disso, que parecia fazer algum sentido naquele contexto, decidiu aceitar o convite. Participou do livro-arte que acompanhou a exposição usando o jornal, exatamente como o havia encontrado, e também levou essa frase para a rua. 


\section{Panorama revela politizaçãona arte}

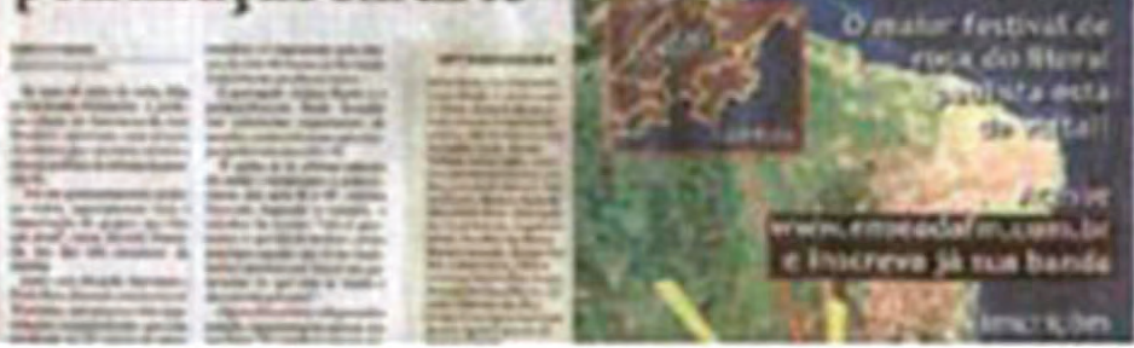

\section{entre 0}

anonimato e

0 estrelato ?

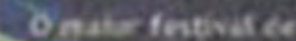

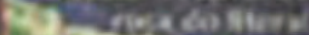

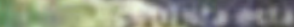
3ital

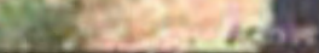

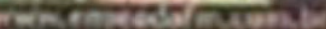

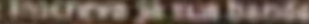
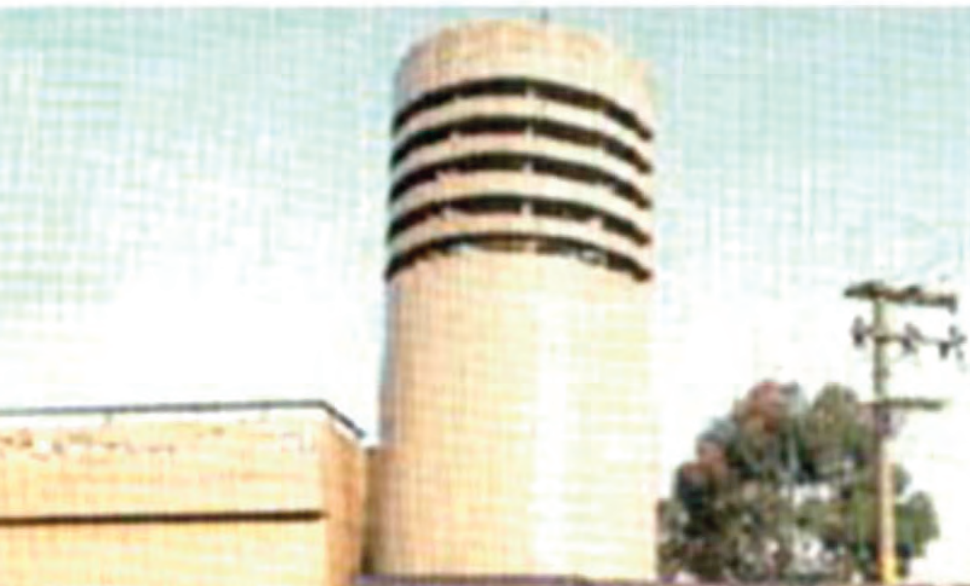

Y oet

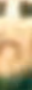
ANONIMATO E O ESTRELATO

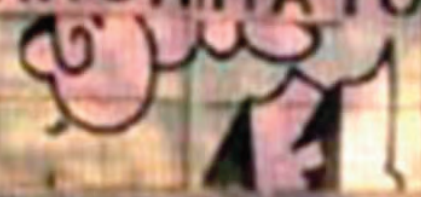
ors T. $\mathrm{H}$

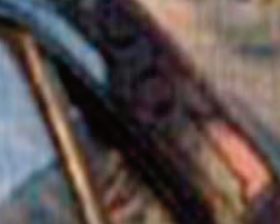




\section{Tentamos encontrar o 'nosso' lugar nessa metrópole, a partir daquilo que vamos construindo e acreditando. [...]}

O próprio trabalho apresentado foi uma metáfora da crise. $\mathrm{O}$ deslocamento da peça de jornal na qual a pergunta publicitária "Qual a distância entre o anonimato e o estrelato?" está ao lado de uma reportagem sobre o Panorama, ao mesmo tempo em que ironizava a situação na qual se encontrava o grupo (que, de totalmente anônimo e avesso às instituiçóes, agora se encontrava em uma grande exposição de arte), tentava mostrar a perspicácia necessária quando este aceitou entrar em um embate de representações. A frase colocada na rua, por sua vez, parecia insistir no anonimato.

Esse parece ser um caso típico da forma como a "crítica institucional" é vivida por essa geração de coletivos de arte. Se, por um lado, a perda do anonimato estava sendo questionada; por outro, isso foi feito a partir da participação na instituição. Se a experiência urbana e os vínculos com os movimentos sociais pareciam ser o lugar mais potente de invenção e resistência, o contato com o mundo dos museus e centros culturais estava também sendo considerado um lugar potente para a ampliação das discussões. Naquele momento, essas variações de perspectiva não foram compreendidas pelo grupo como mobilizadoras da criação de uma postura singular e coerente: a discussão mais parecia estar imersa em um mar de contradições. Isso fez com que as relações grupais se esgarçassem a ponto do MICO se desfazer, o que se deu principalmente porque a discussão sobre "estar ou não dentro da instituição artística" fez com que a vitalidade da rua fosse substituída quase por inteira por essa problemática.

Lendo alguns textos escritos por diferentes coletivos, inclusive 
o Contrafilé, interpretando o que aconteceu com o grupo MICO, a partir da participação no Panorama, podemos ver que se coloca em pauta a necessidade de prontidão e de um estado alerta do corpo em qualquer situação, inclusive na relação institucional, e não necessariamente a negação da instituição. Nesse sentido, se a instituição é entendida como um espaço de disputa, a crítica institucional deve ser a tentativa de encontrar clareiras para justamente anunciar essa situação.

Texto do Contrafilé sobre o fim do MICO, escrito na ocasião do io CIA (Congresso Internacional de $\operatorname{Ar}(\mathrm{r})$ ivismo) ${ }^{89}$ :

Então eu penso que no nosso tempo nós devemos desenvolver a nossa reflexão em torno deste problema do contra, quer dizer, meditar até que ponto nós devemos ser do contra, contra o quê devemos ser, para depois podermos ser, também, a favor. ${ }^{90}$

No 10 CIA (Congresso Internacional de $\operatorname{Ar}(r)$ ivismo) fomos questionadas - como integrantes do MICO - a respeito da participação deste grupo no Panorama da Arte Brasileira 2001 e de seu consequente "desaparecimento".

Até a participação no Panorama, não falávamos sobre as situações, agíamos. Os trabalhos surgiam de tensões, questionamentos comuns a todos os integrantes. A reflexão sobre a prática sempre servia para que déssemos - próximo passo. A transformação estava na experiência e não na discussão teórica mediada pela "Arte".

Depois do Panorama, não só perdemos o pé da experiência como ela se empobreceu, porque ser contra ou a favor do circuito da arte tornou-se (por termos nos inserido nele) praticamente a única situação sobre a qual discutíamos. Ser contra e/ou a favor deixou de ser algo intrínseco e diluído no processo de trabalho, para ser coisa separada e independente. Ficamos em xeque.

89. O CIA foi um momento de encontro de diversos coletivos de arte em outubro de 2003, para discutir as suas práticas de "arte ativista" e confrontar/problematizar o termo "arrivista", que começou a ser usado de forma irônica pela mídia na época para nomear esse tipo de prática. 90. Cândido, Antonio. Tempo do Contra. In: Textos de Intervenção. São Paulo: Duas Cidades; Ed. 34, 2002. 


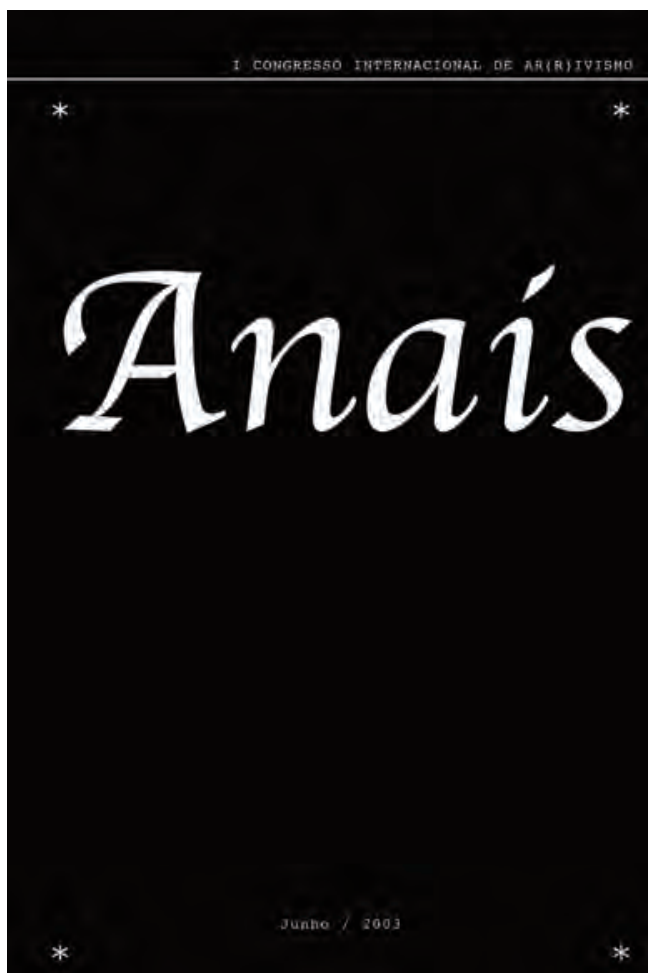

por agul a liberdade e total. mas so dentro do

pensamento.

alguns ainda carregam uma bola de forro atads aos pés.

outros mals solisticados ja subotituiran este sircens.

arcaico por chips ligados a suas orelhad e bocal a

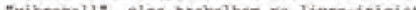

de tanto sereo diferentes, os diferentes yá ilcaram

iguais.

a müsica liberta mesmo quarido confinada em enpaçon restritos?

seja un completo marginal. mas bé ná for, mantenha of seus documentos em dia.

- amor e a comunicacáo poden mudar o mundo. mas peralz! de qual amor yocé esté̉ falando?

am sujeito con um caribso vale mais do que um milhao com cartazes na moso.

o bam-senso es algo tao bes distribuldo que acabors.

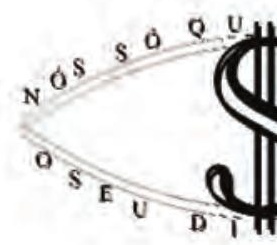

o primeiso alvo de mudanca sera voce.

... I projero telepatia 1 telepatia.tk / profana.com 1. -. ( dariel seda integra o Coletivo formiqueiro).

a Idesia è sair colando esta imagem do olno-cifráo sobre ol hos diversos an displays diversos de propagada, en pontos de ônibus, supermercados, etc cono umil micro antıstodo para a crencea na propaqanda.

.03

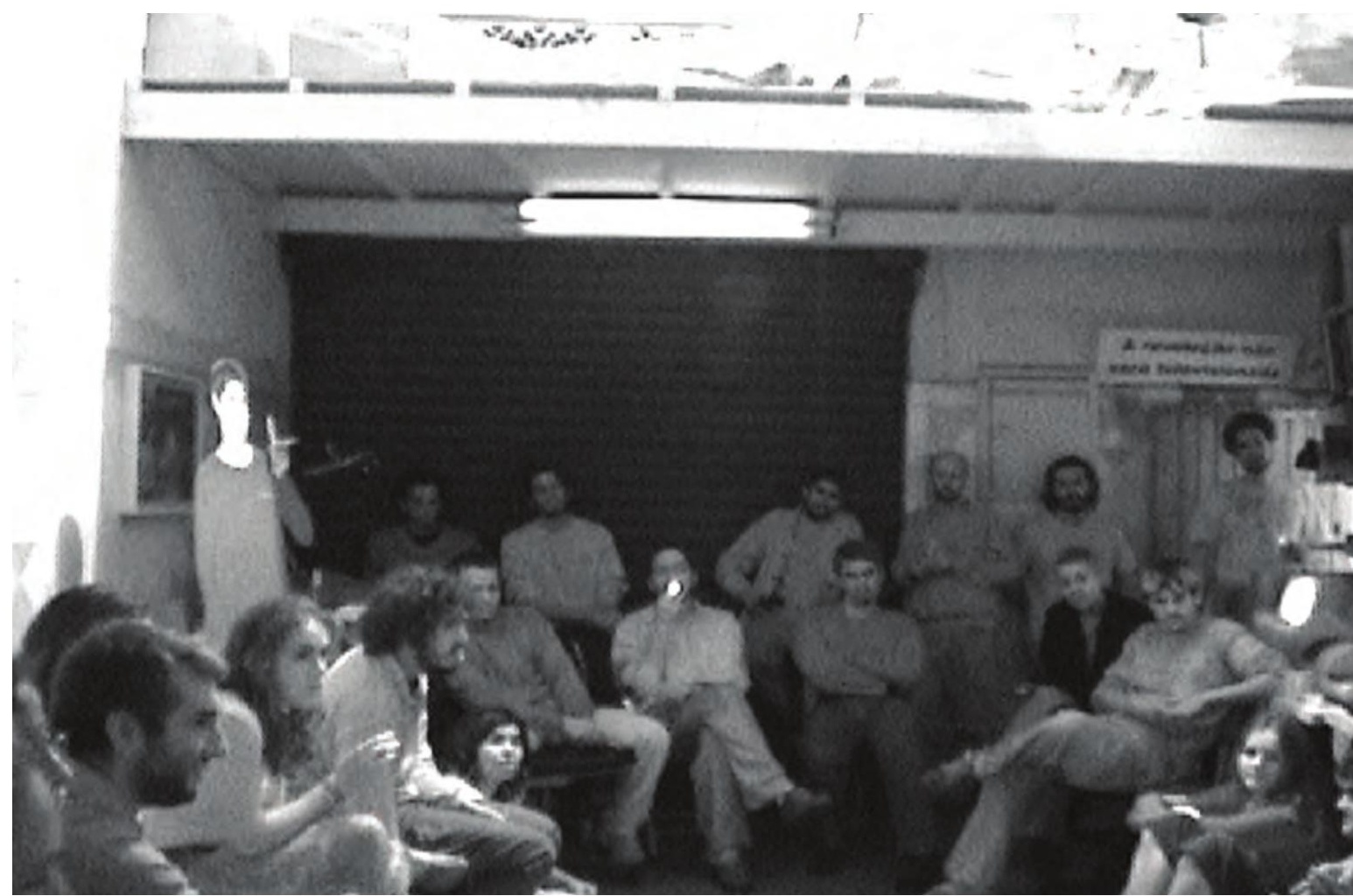

1o CIA (Congresso Internacional de Ar(r)ivismo, realizado em São Paulo em 2003. 
Ora, então a reflexão é esta: se nós estamos entrando efetivamente numa era de conservantismo, temos que ser contra, temos que afiar as nossas armas, temos que, culturalmente e politicamente, nos preparar para ser contra esta tendência das classes dominantes, que vêm forçar os controles de conservação. Nós temos que, a cada momento, manter o contra como a possibilidade de abertura democrática. Temos que manter o contra como única possibilidade de propor a questão da democracia, que é o caminho para a igualdade, que é o que realmente interessa. ${ }^{91}$

Contra e a favor andam sempre juntos e é preciso muita perspicácia para ter um pensamento e uma prática dialéticos. Ou seja, estudar cada momento e responder a ele não a partir de preconceitos e parâmetros exteriores, mas do entendimento de sua densidade. Tendo a clareza de que o sentido das ações é a conquista de uma sociedade realmente democrática, o jogo não precisa ter regras a priori, somente ser jogado.

"Ser do contra" deve ser, portanto, ao mesmo tempo, um desafio e uma conquista. Assim, aparece como tensão, algo que nos atormenta; e deve vir à tona não como discurso, mas como realidade, um possível que nos orienta em direção de um novo "a favor".

Trechos da discussão entre artistas-ativistas paulistas - que depois tornou-se um texto-diálogo na Revista Parachute no. II6 (2003), edição integralmente sobre São Paulo e que foi coordenada por Suely Rolnik:

\section{- Mas o museu não é em si um inimigo. Ele pode gerar, consolidar, disponibilizar e fazer circular conbeci- mento, ao invés de ser apenas um depósito de entulho cívico ou uma Disneylândia cultural. Inclusive, algu-}

91. Id. Ibid. 
maspessoas em museus e instituições culturais, públicas ou privadas, têm pensado nesta direção e acho que há uma aliança importante a ser feita com elas.

- A opção pela intervenção urbana não deve depender exclusivamente desse tipo de aliança... Por mais que se disponham a incorporar estas novas propostas de ação, museus e galerias ainda estão muito distantes de participar deste enfrentamento da violenta separação das práticas artísticas da complexidade da vida cotidiana que temos aqui em São Paulo.

- Por isso, trata-se de uma negociação estratégica desse tipo de arte com as várias instâncias administrativas da cultura, para que elas se constituam como produtoras de conbecimento e de realidade. $O$ desafio é exatamente criar modos de traduzir formalmente essa necessidade que surge do investimento no real, da relação com o outro, do encontro com a cidade. Então, o lugar da nossa ação não tem a ver com espaço público no sentido de espaço aberto, exterior ao espaço fechado, mas sim com vida pública que se produz tanto em espaços abertos como fechados, sejam eles estatais ou privados.

Trechos do livro do GAC (2009), nos quais refletem sobre as relações que estabeleceram ao longo do tempo e em diferentes ocasiōes e situaçóes, com os convites para participar de projetos expositivos e de interações com outros grupos mediadas por alguma instituição cultural ou artística: 
A lo largo de estos años fuimos viendo cómo todas las experiencias vividas en cuanto a las relaciones con instituiciones nos fueron moldeando, reconfigurando permanentemente en relación a los demás o, para decirlo de manera más clara, nos fuimos 'curtiendo'. A la par de lo que experimentaban otros grupos semejantes en Buenos Aires [...] descubriamos las diferentes posturas que existian y existen entre nosotras. Esta mutabilidad que se describe en los textos precedentes, esta movilidad de posiciones es la que nos permitió siempre continuar, buscar permanentemente la vuelta. Reformular todo el tiempo los contenidos, los formatos, los dispositivos, los destinatários: qué, cómo, para quiénes. Un ejercicio de pensamiento y producción del cual no siempre se sale ilesa [...] $\Upsilon$ también saber decir no, en algunas ocasiones. Una de las cosas que más rescato de todo este proceso, o quizá porque lo viví como una transformación positiva en el grupo, como un aprendizaje, es el pasaje de una posición 'dura', excesivamente intransigente y juzgadora a una actitud más permeable, menos prejuiciosa y moralizante con respecto a la vinculación con instituciones. Profundizando en esta transformación, podría decir que bubo un momento en el cual nuestra identidad grupal estaba muy impregnada de cierta visión 'purista' sobre el tema, como una espécie de desconfianza anticipada, alimentada por algunos dogmas éticos de la militancia más tradicional. Una especie de reglamento moral no escrito, pero compartido, 
aunque más no sea un estereotipo de cómo debe comportarse, pronunciarse, y por qué opción debe optar todo colectivo que se autodenomine militante. Esa mirada se puso en crisis en el momento en que nos convertimos en destinatárias de esa misma mirada jusgadora. Viendólo desde el presente pienso que quizás el núcleo de esa crisis se visibilizó más claramente durante nuestra participación en la Bienal de Venecia. A partir de abí comenzó un proceso muy largo, al tiempo que muy duro, de replanteamientos y reposicionamientos. Digo duro porque nunca es placentero reconocer actitudes tan condicionantes, tan limitantes en una misma y en el interior del grupo al que una pertenece. Y el trabajo que implica cambiar esto, superar estas barreras y transformar concepciones tan arraigadas no es algo que muchos grupos hayan logrado [...] Cuántos grupos se disolvieron intentando atravesar esa frontera? Cuántas experiencias interesantes en el campo de la producción simbólica cayeron en la trampa mortal de la supuesta 'cooptación'? Cuántos quedaron enredados en el juego epistemológico 'autonomia vs. institución', como se fuera más legítimo representar todo lo que se hace en términos de una polaridad irreconciliable?

A acepção de crítica institucional aqui utilizada é a desenvolvida por Brian Holmes, que entende que nessa geração a crítica se configura como uma deriva extradisciplinar (Holmes, 2007) - na qual as práticas se conectam com os movimentos e fatos sociais, mas não deixam de voltar 

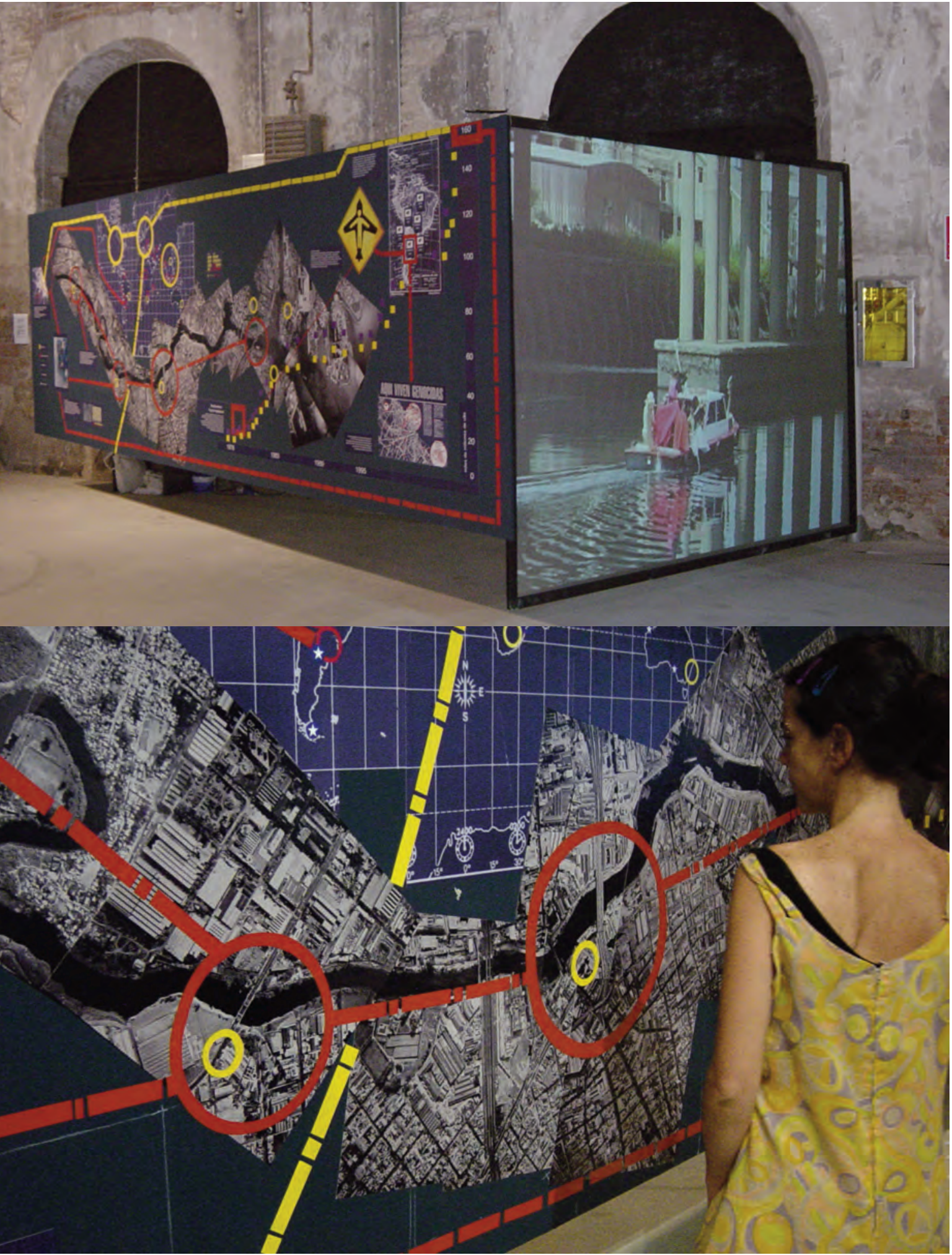

Trabalho do GAC na 50a Bienal de Veneza, Veneza, Itália, 2003. 
PROJETO JO 08B:Layout $1 \quad 7 / 25 / 12 \quad 11: 36$ AM page 254

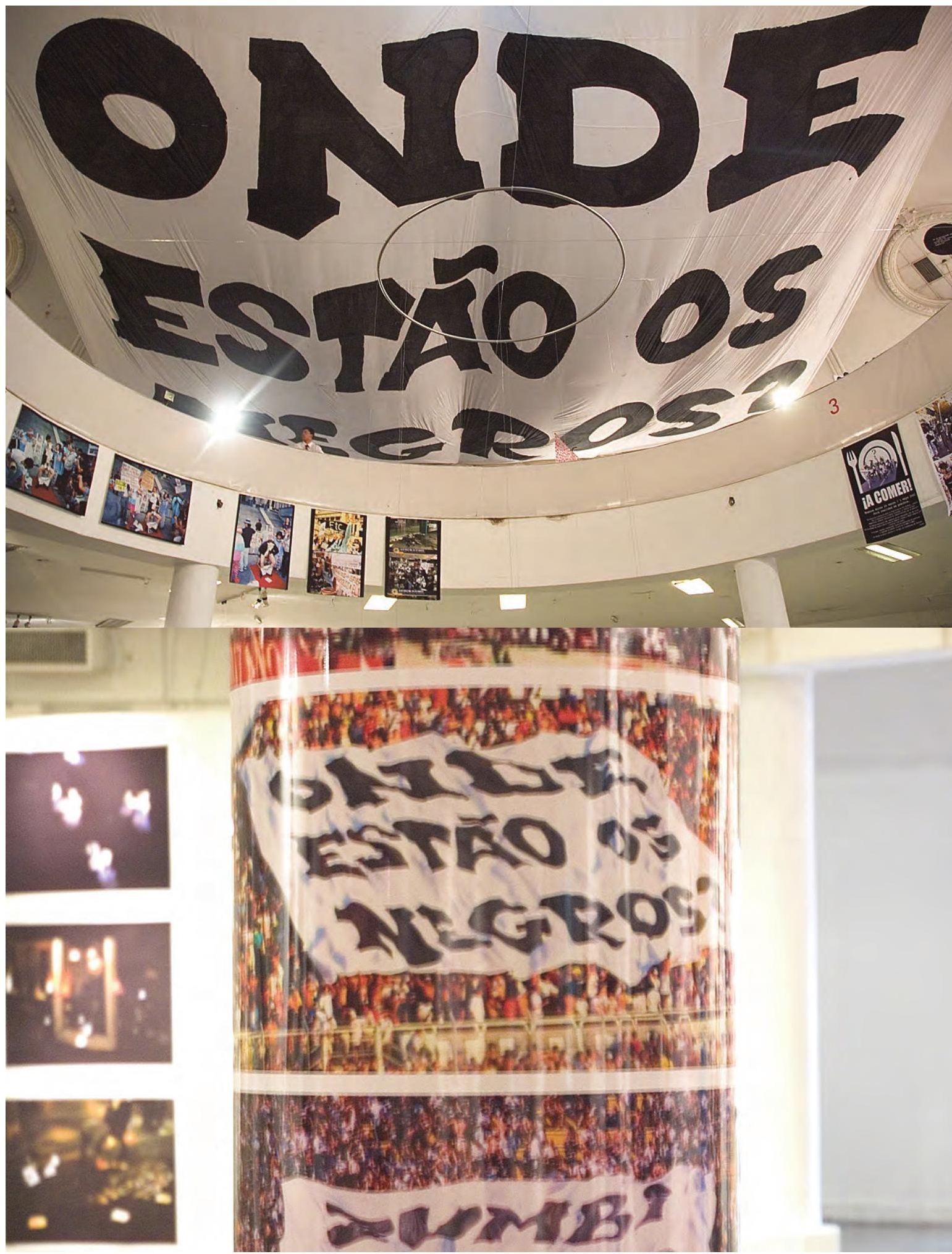

Trabalho da Frente 3 de Fevereiro na exposição La Normalidad, Buenos Aires, Argentina, 2006. 
ciclicamente ao campo institucional, com o intuito de aprofundar e politizar o grau do debate em tais espaços.

Como em práticas similares que se fazem hoje por toda parte, uma das caracteristicas das estratégias atuais é a deriva extraterritorial - que, no caso do Brasil e de muitos países da América Latina, privilegia a conexão com práticas sociais e políticas (por exemplo, $o$ Movimento Sem Teto do Centro na cidade de São Paulo). Isso não implica, no entanto, em desertar por completo da instituição artística, com a qual mantém-se uma relação despreconceituosa, num movimento fluido de idas e vindas, que a cada volta tende a injetar em seu corpo agonizante doses de força poética que promovem sua desterritorialização crítica. Esta é uma outra característica de tais práticas, que as diferencia das propostas marcadas pela crítica institucional dos anos 1960 e 70, como sugere Brian Holmes. O autor qualifica tal deriva como 'extradisciplinar', para designar o que ele circunscreve como a terceira geração da crítica institucional, de modo a distingui-la das geraçôes precedentes: a primeira, dos anos $1960 \mathrm{e}$ 7o, que ele caracteriza como 'anti-disciplinar'e, a segunda, dos anos 80 que, segundo Holmes, leva o movimento da década anterior ao seu limite, revelando o impasse ao qual a arte se vê confrontada ao manter a crítica no interior da própria instituiçāo artística. A tendência extradisciplinar que se afirma nos anos 1990 é uma resposta a este impasse, bem como as questôes colocadas no contexto do neoliberalismo, cuja hegemonia internacional coincide com o surgimento desta geração de artistas (Rolnik, 2007).

Ricardo Basbaum, em texto escrito para o catálogo do "Panorama da Arte Brasileira 20oı" (p. 35-40), apesar de não falar nos 


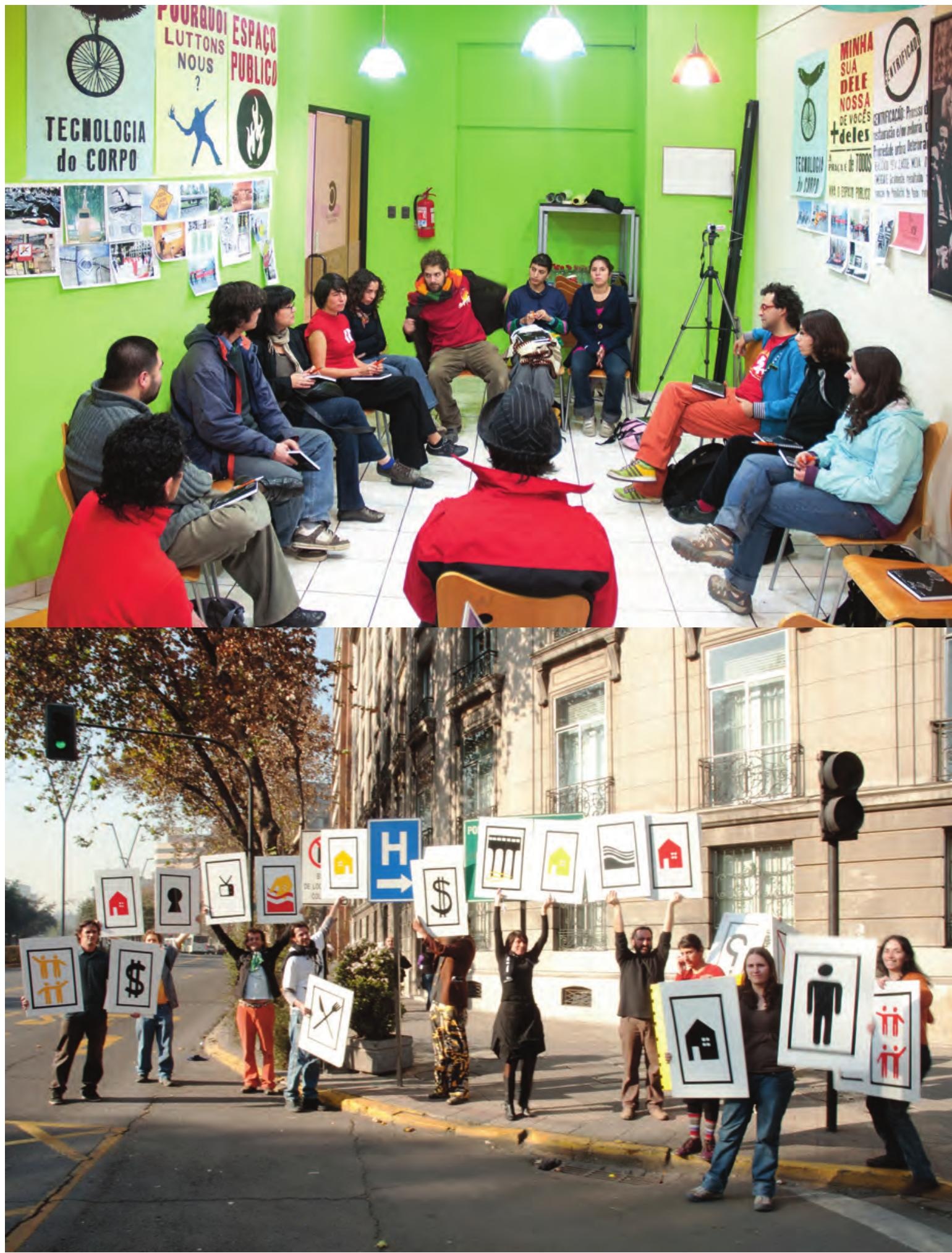

Contrafilé e Bijari no Seminário Arte, Estética e Política Urbana: Pensamentos e Práticas

Artísticas e Sociais no Espaço Público da América Latina, no Centro Cultural da Espanha,

Santiago, Chile, 2009. 
mesmos termos que Holmes, evoca a perda dos contornos claros do que pode ou não ser uma obra de arte a partir do pós-1945, associando o "ser artista" com um trânsito, um "certo deslocamento através das coisas combinado com a produção de um espaço particular de problemas"; portanto, ser artista não seria para ele uma identidade com limites rígidos e absolutos. Essa concepção de Basbaum sugere que a dinâmica que forma o "ser artista" envolve uma determinada configuração do sensível na qual certas situações, objetos e eventos são formulados, "deflagrando toda uma economia própria deste conjunto de operaçôes”.

Para podermos aprofundar a relação aqui sugerida entre a "deriva extraterritorial" e o "ser artista" como "um trânsito delimitador de uma certa configuração de problemas", lanço mão do conceito de performance, tal como apresentado pela antropóloga Florencia Ferrari (2OIO). Passando por autores como Victor Turner, que relaciona a performance com o ritual e com a restauração de situações de conflito para a constituição da comunalidade; e Judith Butler que, nos estudos de gênero, entende que alguns gêneros só existem na medida em que são performados, a autora constrói o argumento de que a "calonidade" (o estudo é sobre ciganos Calon) não é vivida ou entendida como uma identidade fixa ou uma essência, mas como um eterno processo de "fazer-se calon", um agenciamento que se configura a partir de certos "atos afetivos" que constituem a realidade. Sendo assim, para Ferrari, “a ideia mesma de 'essência calon' inexiste, na medida em que a calonidade é entendida como um processo de 'fazer-se', de 'fazer aparecer'. A performance das emoções é, nesse sentido, constitutiva do modo de 'fazer-se calon' que deve ser mostrado, compartilhado" (Ferrari, 20IO, p.174-175).

Aperformance compreendida como um processo de "fazer-se" a 
cada momento, a partir da delimitação de certos modos de agir, está sendo aqui utilizada como referência à forma como a "crítica" é vivida e se constitui nessa geração. Acredito que a falta de lugares e referências identitárias ou territoriais fixas do que seria uma prática ou um artista crítico, leva ao medo de deixar-se sucumbir no interior da instituição em um processo de "indiferenciação". A "deriva extraterritorial" é então acionada como uma estratégia fundamental para o restabelecimento de uma "linha de fuga", na qual acontece e toma corpo o processo de "(re)fazer-se" crítico, de mobilizar-se e mobilizar o espaço de modo a restaurar constantemente as situaçôes de conflito. É uma estratégia para relembrar o corpo, a todo instante, o "estado do mundo"; ou seja, as questões sociais, políticas, econômicas e culturais (entendidas macro e micropoliticamente) urgentes de serem acionadas e pensadas, estando dentro ou fora da instituição. A prática crítica para essa geração pode ser compreendida como real, portanto, apenas na medida em que é performada; em que se torna uma prática mais performativa do que reprodutiva, o que significa que não existe um espaço e certas concepçóes pré-determinadas para distingui-la, mas que ela pode ser ou não deflagrada a cada momento.

Marcelo Expósito, pensador espanhol que teve contato, em diferentes situações, com os coletivos de São Paulo e dialoga com coletivos do mundo todo, em seu texto "Entrar e salir de la instituición - autovaloración y montaje en el arte contemporáneo" (2006), demonstra essa necessidade de compreensão do que significa a crítica na atualidade:

Desde hace ya algunos años ha habido una continuidad de proyectos que se plantean una relación ni cínica ni instrumental con la institución, con el fin de generar prácticas críticas en su interior buscando 
su puesta en valor simultáneamente abi y en otro lugary momento, bajo otras formas. Se trataría de 'entrar' y 'salir' de la institución como un continuo en el que la puesta en forma institucional no se evite, e incluso se contemple, sin ser el objetivo central. Producir redes y flujos que no respetan demarcaciones previas y constituyen a cambio sus formas propias de esfera pública - un concepto que seguramente comienza a quedársenos algo estático - es con seguridad una de las invenciones más importantes de la creatividad política de este nuevo ciclo.

Me parece que são justamente essas redes e fluxos, que não respeitam demarcações prévias, essa forma de subjetivação que não entende o "ser crítico" como uma identidade ou a identificação com um lugar pré-definido e fixo, mas como um ato de "(re)fazer-se constantemente", o que cria as condições para que a potência do que é mostrado e compartilhado, portanto performatizado enquanto crítica social, aconteça justamente nesse ponto de tensão: a ação parte necessariamente de uma crise de sentido (daquilo que está sendo experienciado) que abre uma lacuna a partir da qual o projeto de espaço a ser construído fica em evidente negociação. Por sua vez, é essa negociação constante do espaço, gerada pela experiência singular e oblíqua do mesmo, que coloca em xeque as "identidades inamovibles que responden a modos de vivir que no cuestionan el lugar que se les ha otorgado en el mapa del poder" (GAC, 2009, p. 42).

$\mathrm{O}$ que esse tipo de estratégia artístico-urbana-crítica tenta fazer, é justamente criar a imagem do instante no qual essa ruptura crítica se espacializa de diferentes formas, não aceitando uma ideia préconcebida nem do que seria "a crítica", nem do que seria, a priori, o "certo e o errado" como atitude individual ou coletiva em relação à ex- 
periência e sua interpretação. Para definir essa recusa em estabelecer uma posição que anteceda a experiência, Expósito utiliza o conceito de espaço beterotópico ${ }^{92}$, de Foucault:

Parece-me muito oportuno que comece a reluzir o conceito de espaço heterotópico de Foucault. Acredito que chegamos a um ponto em que, a propósito dos processos politicos dentro/fora dos mecanismos instituídos, é conveniente discutir sobre a dicotomia dentro/fora das instituiçôes culturais. De que maneira podemos defender processos políticos transbordantes e um tipo de produção politica excedente que fortaleça áreas onde seja possível uma gestão autônoma da experiência social, evitando cair em uma simplificada tendência a 'trabalhar fora das instituiçôes?? Ou, como podemos ultrapassar posiçōes antiinstitucionais primárias e apriorísticas, ideológicas? $O$ espaço beterotópico foucaultiano não é dentro nem fora, é um outro espaço; e penso que se trata de produzir espaços de autonomia que sejam outros, operando em uma topografia que nos seja própria, que não respeite as demarcaçôes nem as fronteiras entre um dentro e um fora que impõe os mapas estabelecidos (Expósito, 2006, p. 355).

A possibilidade de espacializar, a cada momento, a negociação do espaço, ou seja, de criar formas de tornar visíveis e legíveis os processos compartilhados de produção e invenção concreta do social em sua multiplicidade e variação, está no desejo e na crença contidos na performatização da crítica. Por isso, o corpo é central: é nele e através dele que a experiência se torna um "agir" reconhecível e legítimo, fazendo o desejo circular.

92. Michel Foucault, no texto da conferência proferida em 1967 "De Outros Espaços", elabora o conceito de heterotopia para mostrar que "o espaço do outro" foi esquecido pela cultura ocidental. Grande parte do empreendimento filosófico de Foucault foi resgatar os espaços do outro, os quais o exercício do poder pela racionalidade ocidental buscou suprimir pela busca do "espaço do mesmo". Por isso, estudou espaços onde se exerciam relações de poder com vistas a objetivação do mesmo, como: as prisões, a escola, o corpo, a loucura, a sexualidade, etc. Segundo o autor: "A época atual seria talvez de preferência a época do espaço. [...] Estamos em um momento em que o mundo se experimenta, acredito, menos como uma grande via que se desenvolveria através dos tempos do que como uma rede que religa pontos e que entrecruza sua trama". 

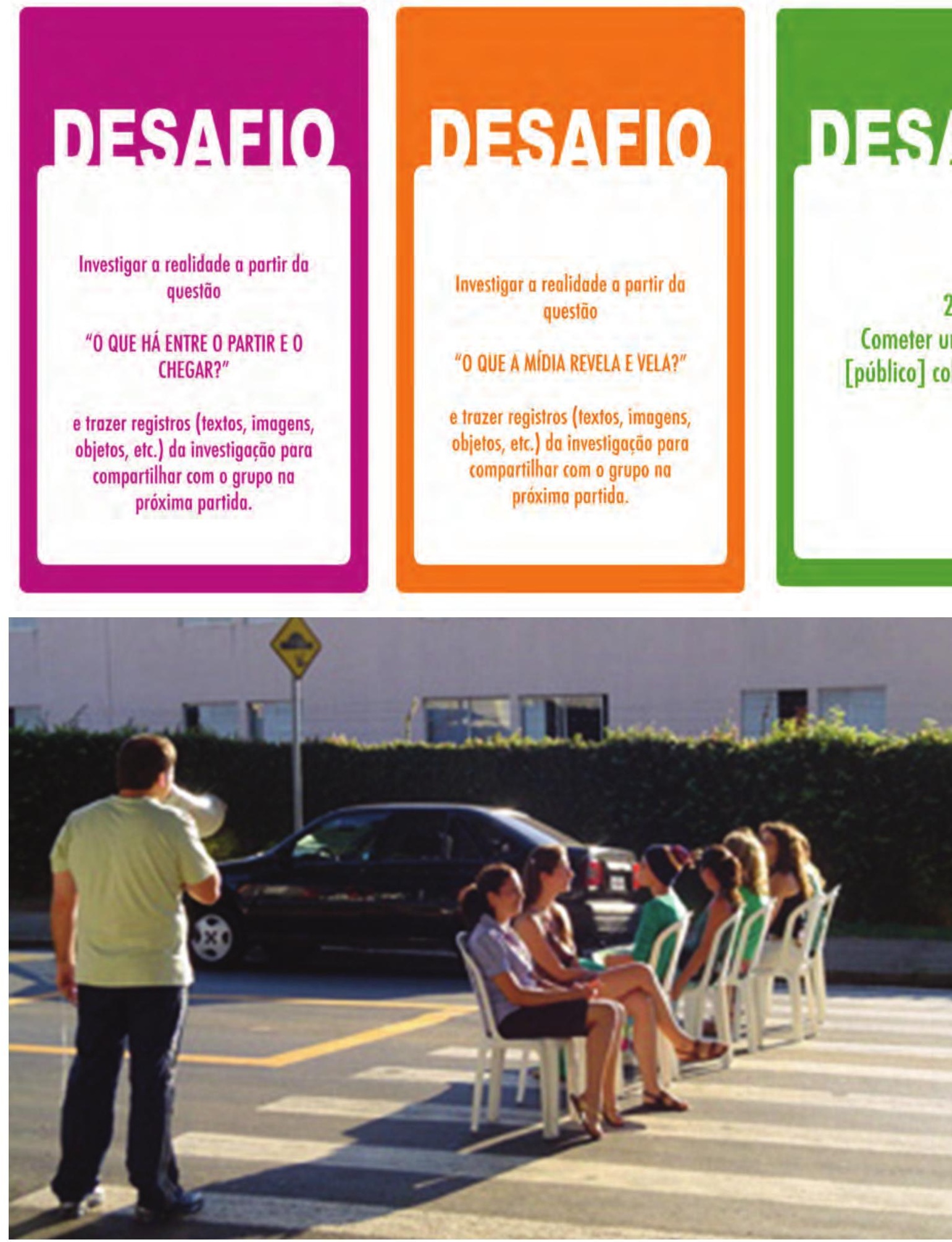

Jogo do Absurdo Público, Contrafilé e PI, entre 2005 e 2011. Imagens de trabalhos realizados pelo Contrafilé e pelo PI com comunidades ou em cursos livres, nos quais a ideia de "absurdo público" deu origem a uma série de experimentações. Campinas, 2006. 


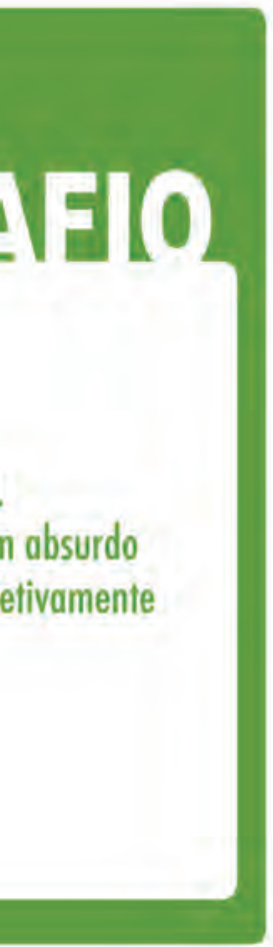

\section{DESAFIO

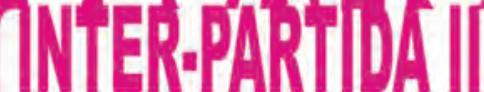

PROPOSTA:

Percurso Coletivo na cidade

Pegar o ônibus "bairro Bananal" no Mercadão. Ir até o ponto final no bairro. Registrar as diferencas percebidas ao longo do percurso. Ir em grupo e trazer registros, elementos da experiência.

\section{DFSAFIO}

Investigar a realidade a partir da questōes

"ATE QUE PONTO ESSES ESTADOS (INSTITUICĀO E ANIMICO) SE INTER. RELACIONAM E SĀO ALTERADOS ATRAVÉS DA COMUNICACĀO, PROVOCANDO TRANSFORMA CÃO, MUDANDO A ORDEM ESTABELECIDA? COMO CRIAR UM ESTADO ONDE NÄO HAJA SUBJUGACÄO, CONTROLE DESMEDIDO, ABUSO DO PODER?

COMO TIRÁ-LO DO PLANO UTÓPICO?"

e trazer registros (textos, imagens, objetos, etc.) da investigoção para compartilhar com o grupo na próxima partida.

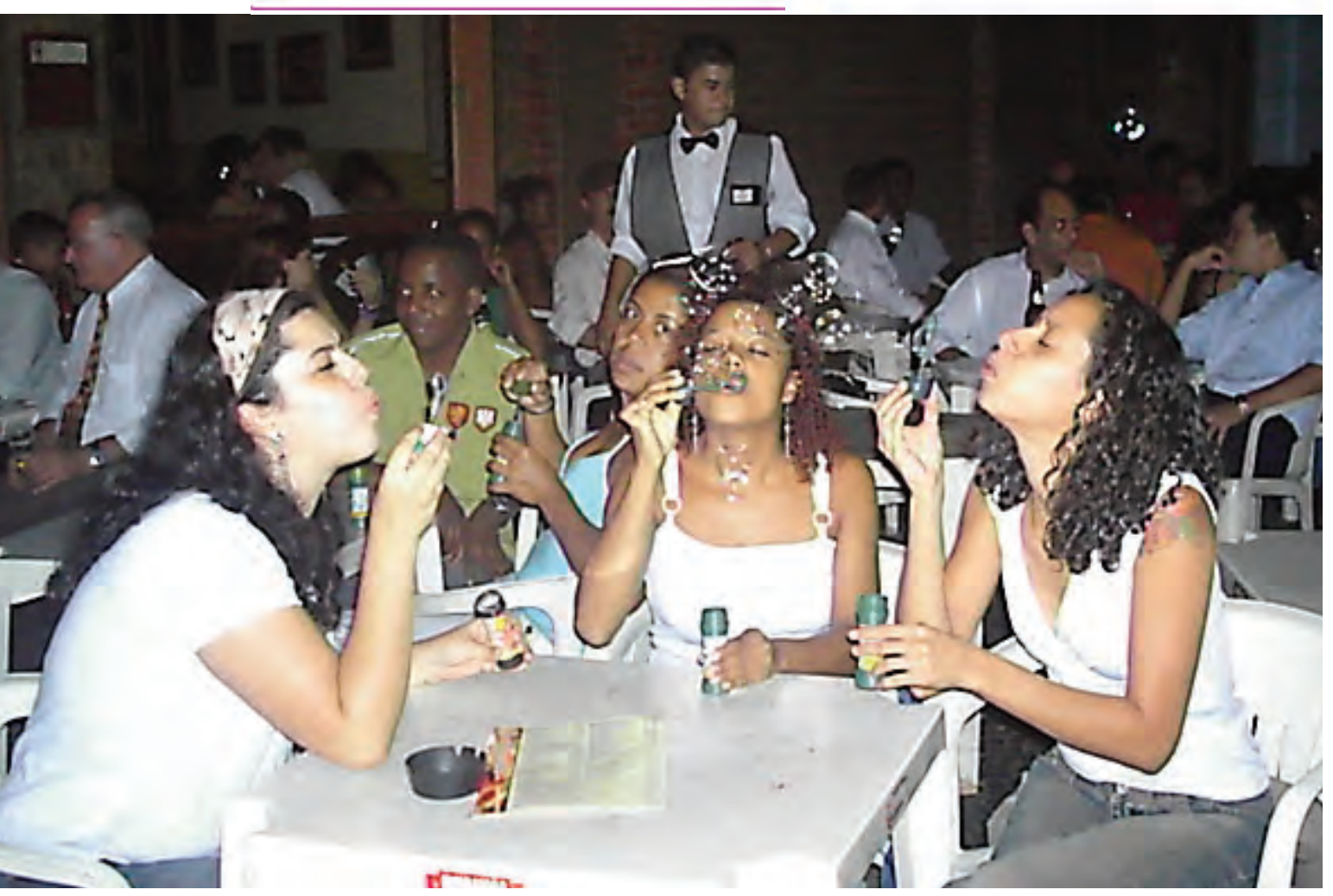




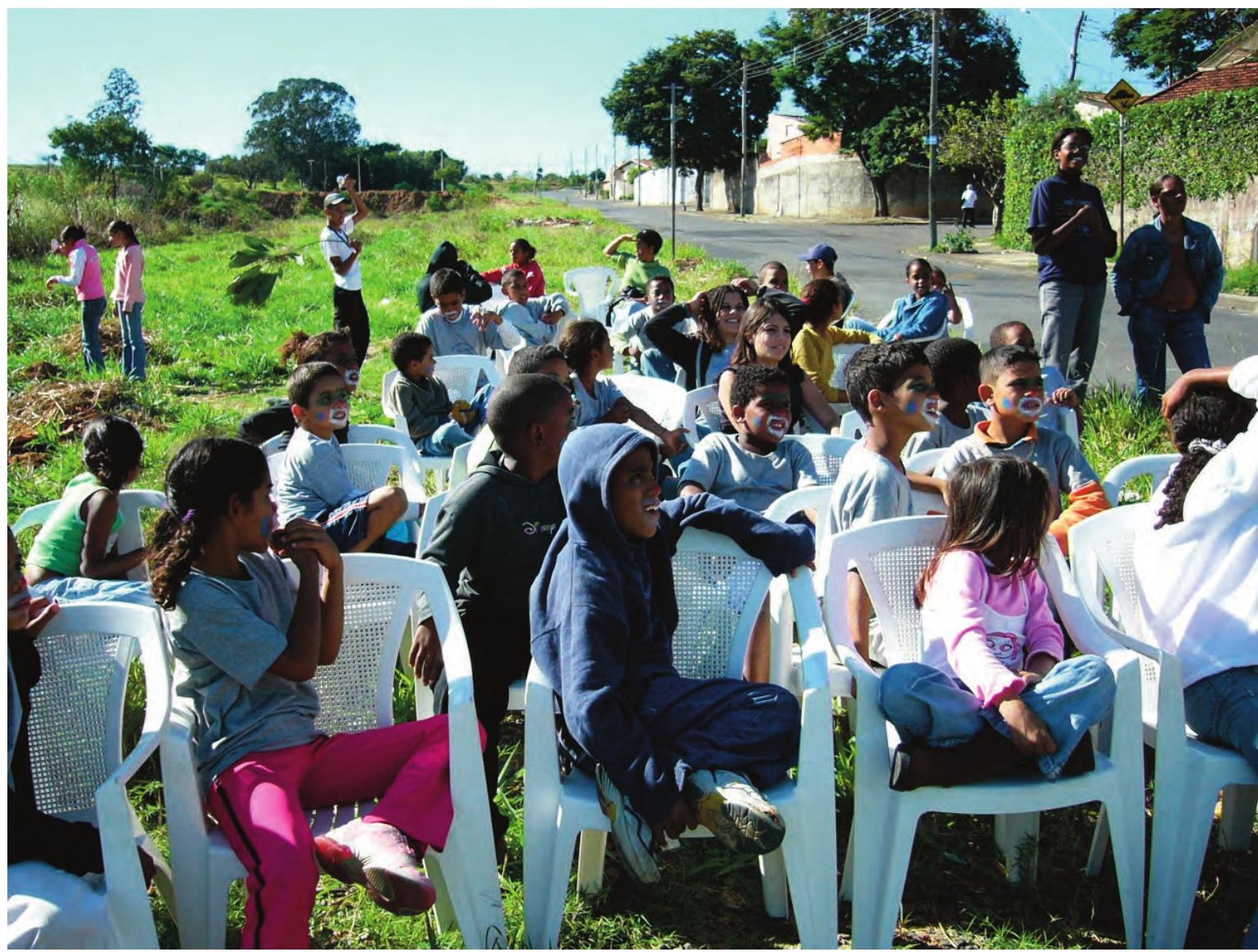

O "Jogo do Absurdo Público" convocava uma comunidade ou grupo a criar um absurdo e vivê-lo no espaço urbano como campo de experimentação, como forma de restaurar uma certa energia do corpo em confronto com a cidade. Isso era algo que os grupos viviam nas intervenções urbanas e que sentiam que restaurava uma situação na qual todos viviam um conflito de forma compartilhada, o que levava à experiência do comum. Era, de certa forma, uma tradução da performatização crítica que exerciam constantemente, seja dentro ou fora das instituições, e um desejo, enquanto educadores, de que outras pessoas pudessem viver isso com eles. Campinas, 2006. 

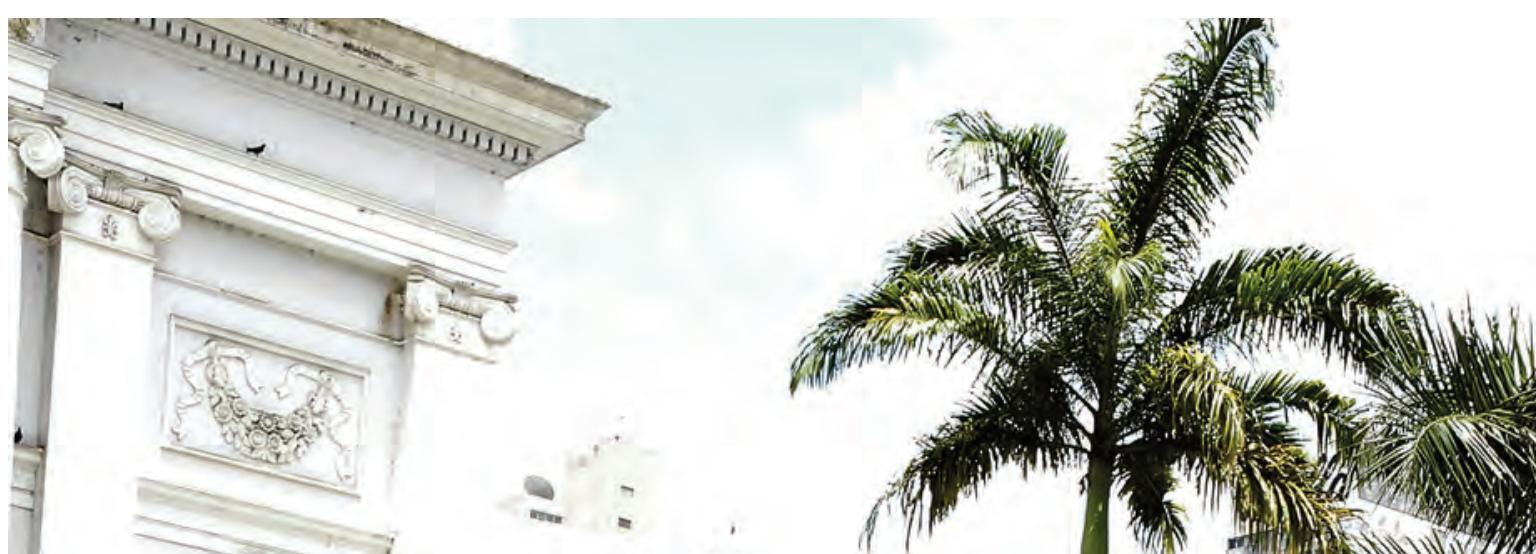

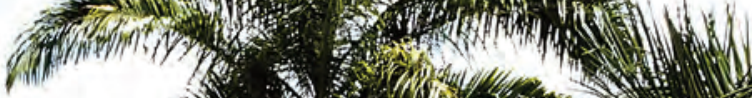
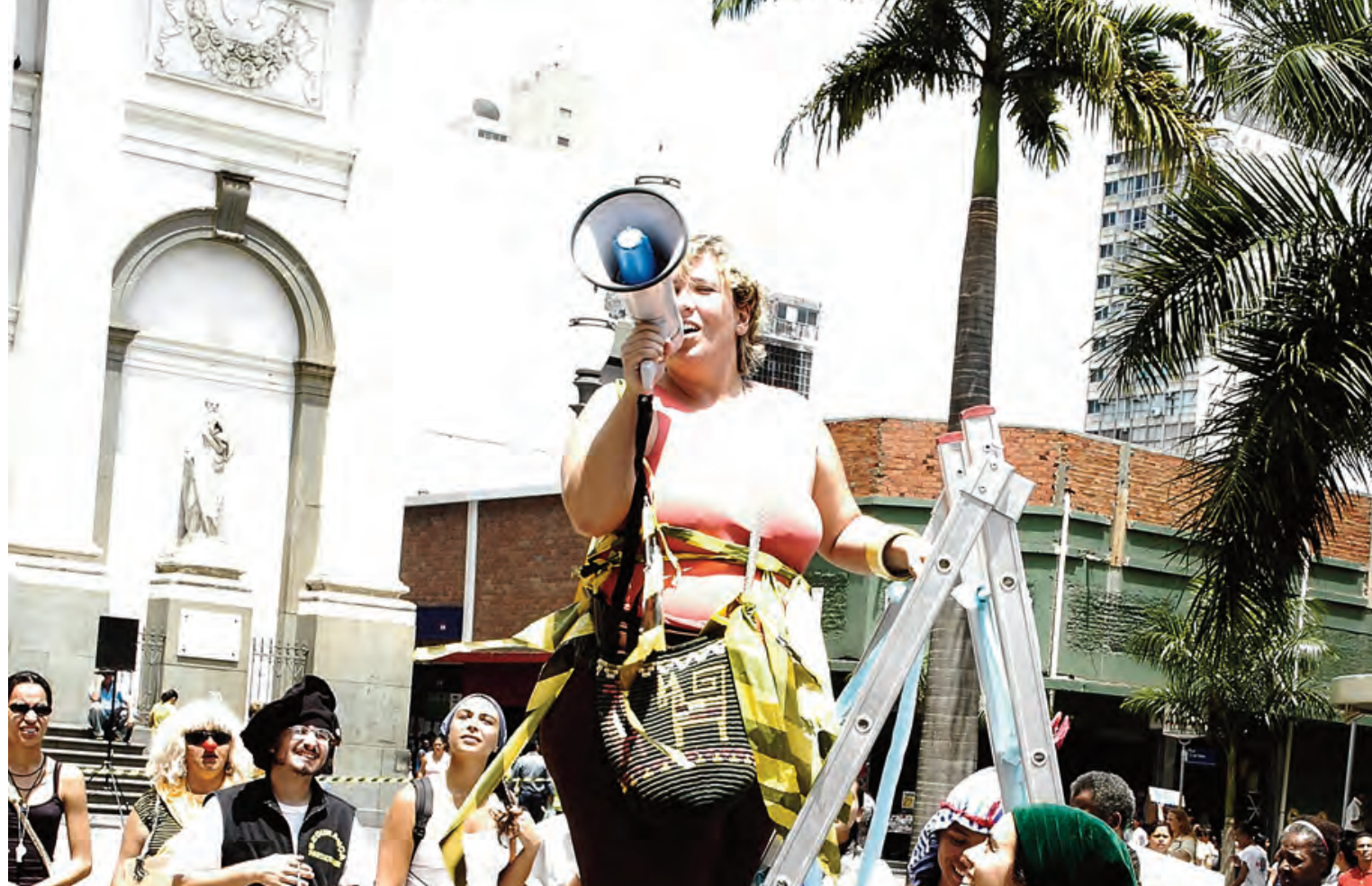

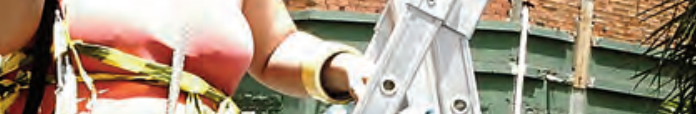
inition

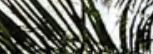
11N- - thing D.s. 12 in ind T) iv Mus $=$ in III) n'ti if (n) Nit
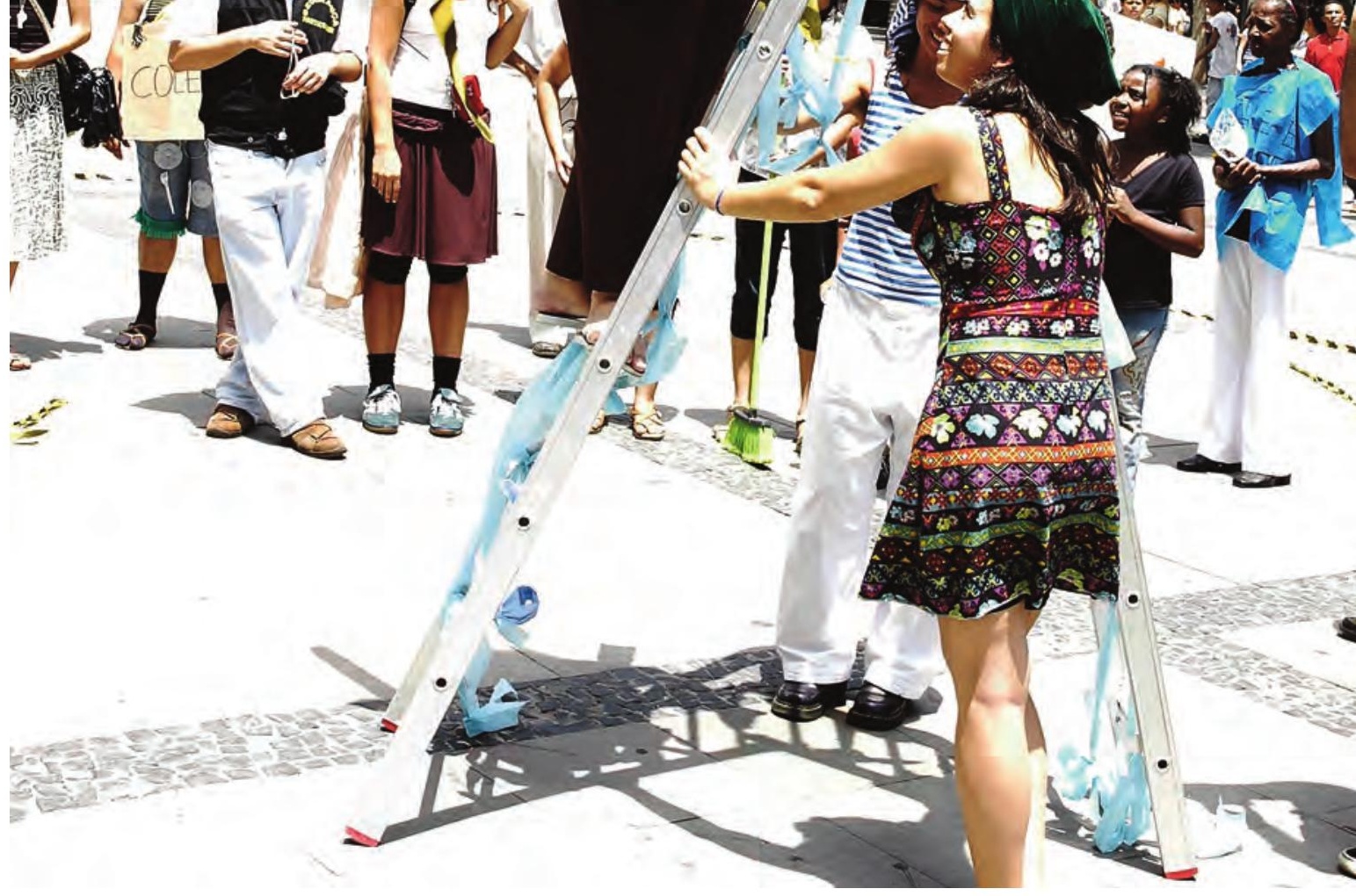
a $\rightarrow 10$ (a) (1) Q

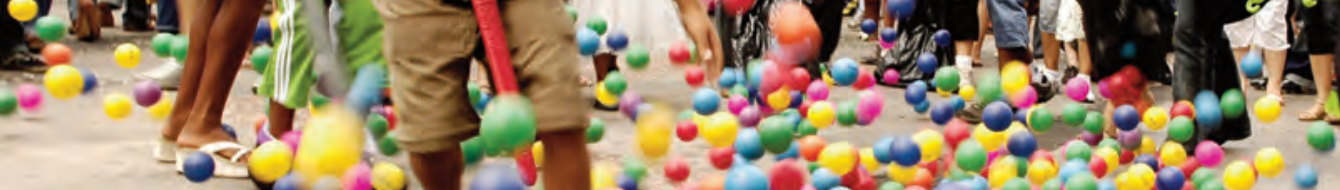

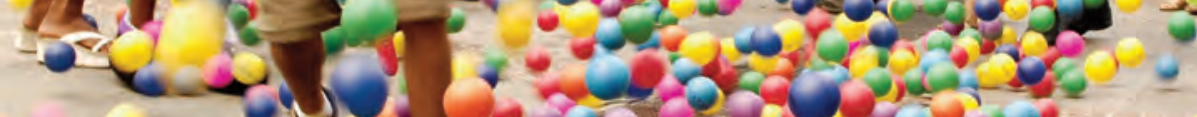

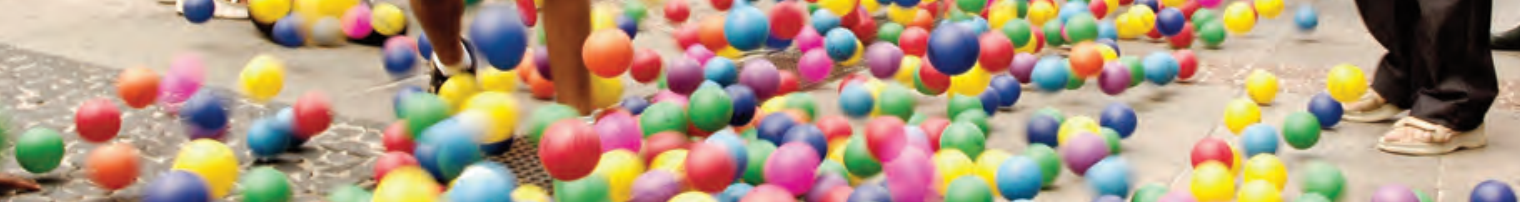

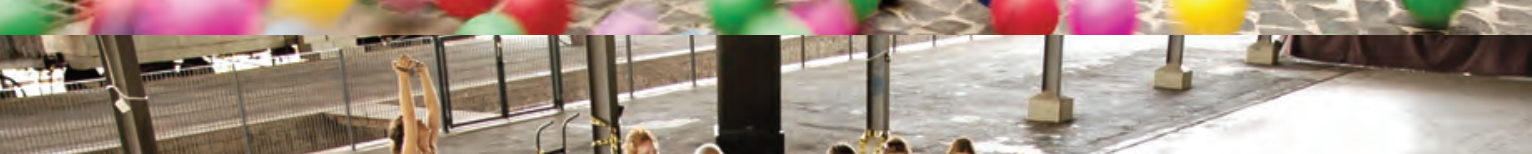

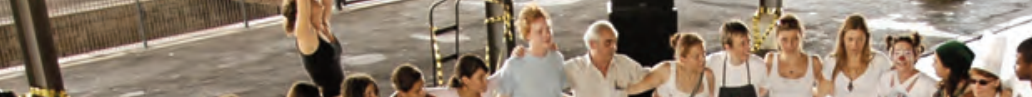

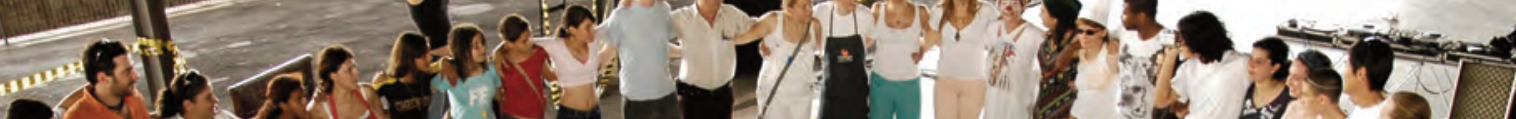

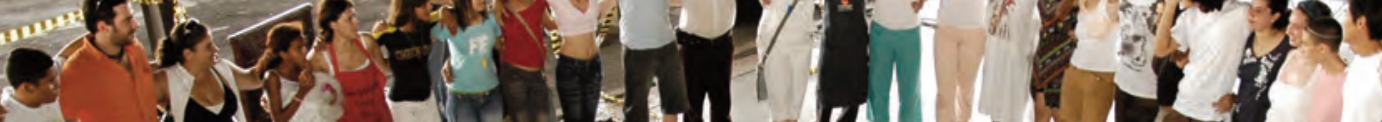
atrie:

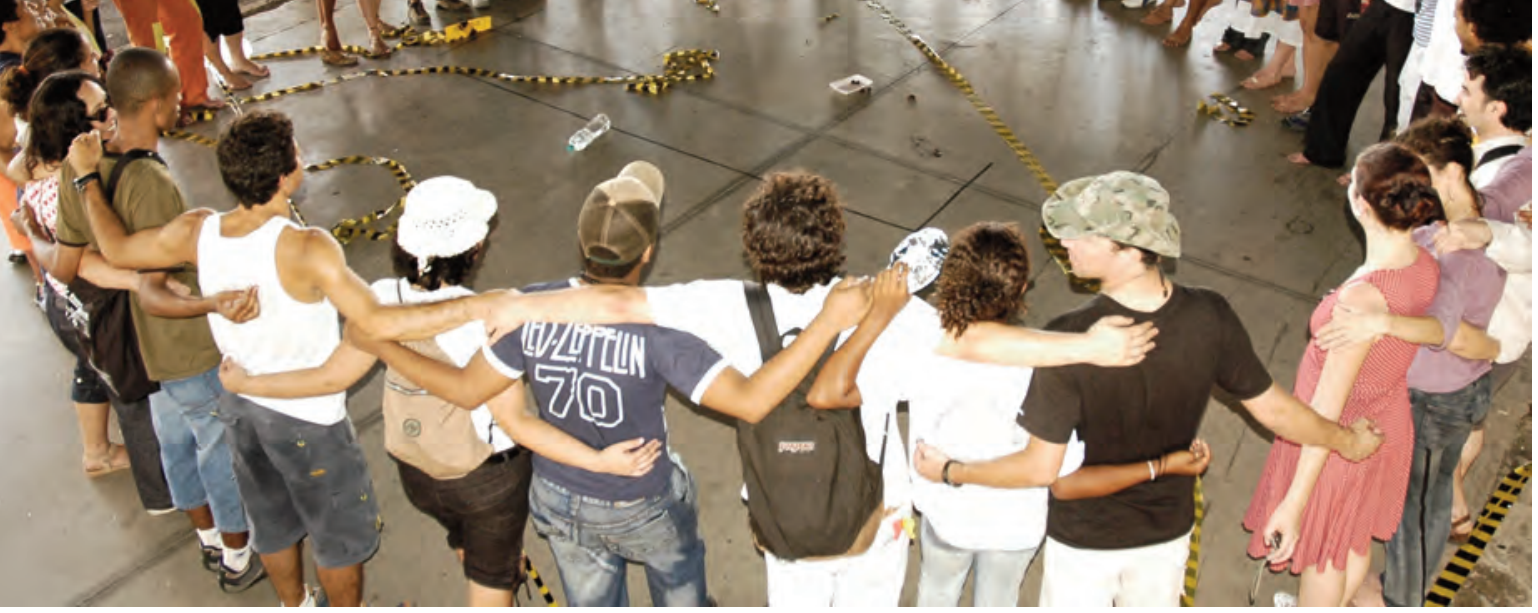


CAPÍTULO IV

Eles não podem partir sem nós 

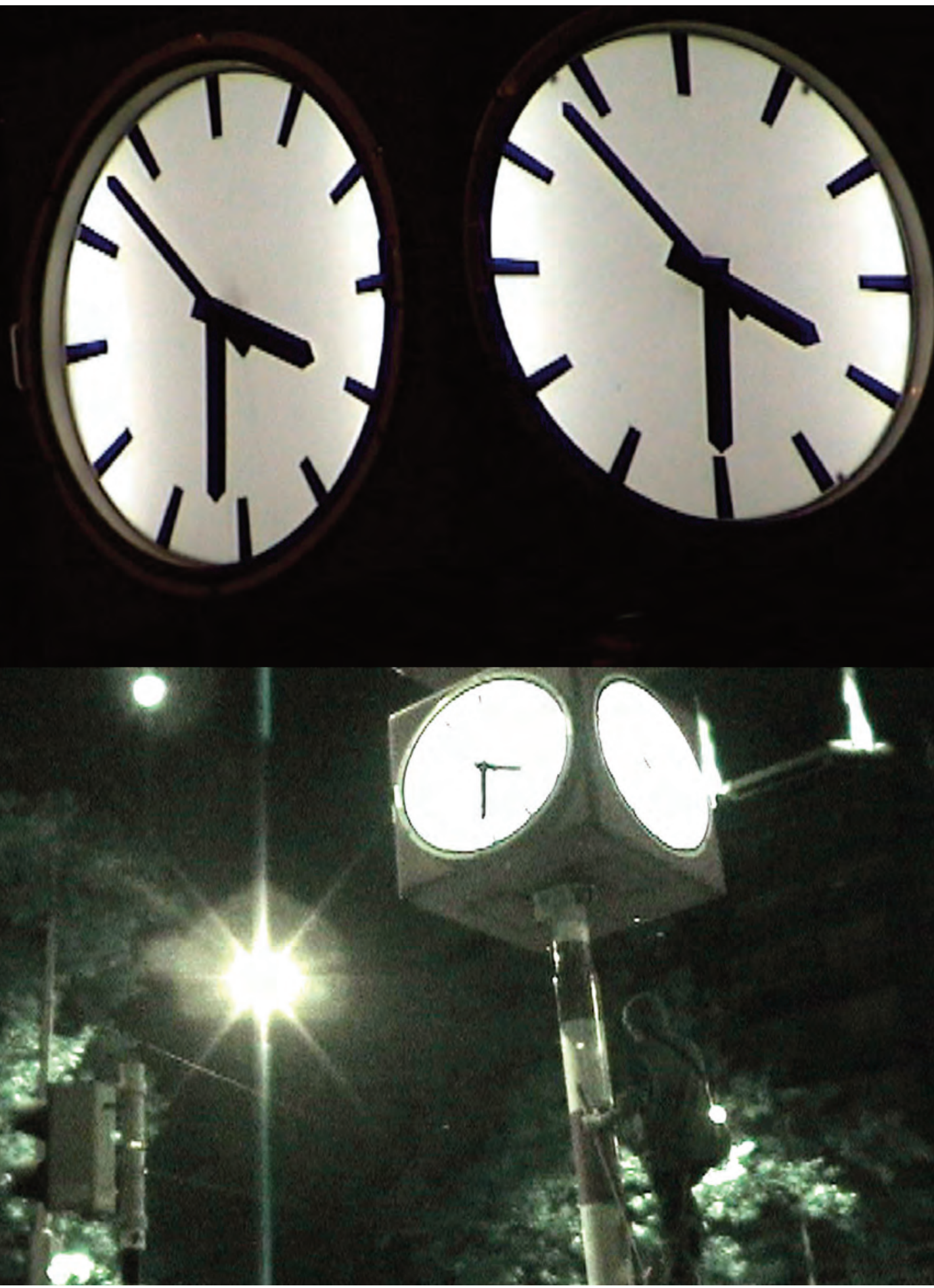

Instalação dos ponteiros de relógio em Rotterdam e a intervenção já realizada, Contrafilé, 2003. 


\title{
Local e Global: escala r:I em movimento
}

\author{
Contrafilé $\gg>$ ROTTERDAM ${ }^{93}$ \\ Em que medida é possível realizar uma intervenção em \\ espaço estrangeiro?
}

Olhar para o espaço com a noção de lugar é ponto fundamental do trabalho, porque é no lugar que encontramos material para a ação e para a sua própria transformação.

- lugar é a porção do espaço apropriável para a vida - apropriada através do corpo - dos sentidos - dos passos de seus moradores, é o bairro, é a praça, é a rua, e nesse sentido poderíamos afirmar que não seria jamais a metrópole ou mesmo a cidade latu sensu a menos que seja uma pequena vila ou cidade - vivida / conhecida / reconhecida em todos os cantos. ${ }^{94}$

A intervenção em um lugar requer a criação de um diálogo, situação que compreende a relação entre o conjunto de experiências prévias do artista e os elementos com potencial de ruptura que ele identifica no contexto - elementos que propõem um horizonte possível, um estranhamento revelador das contradições inerentes ao lugar, as quais evidenciam o artista, e qualquer sujeito, como agentes fundamentais da construção deste espaço.

Para tanto, o artista deve levar consigo nada além de seu corpo. O olhar atento e aberto, que se deixa atravessar pelo lugar, possibilita a percepção do que, dessa interação, se apresenta como tensão. A tensão identificada, passa a ser a problemática para a qual o artista criará uma proposição. Assim, ela sugere a intervenção.

93. Texto reflexivo escrito pelo Contrafilé ao voltar da Holanda, depois de ter participado do projeto Gear Inside (ver logo abaixo). Arquivo pessoal do grupo.

94. Carlos, Ana Fanni Alessandri. O Lugar no/do Mundo. São Paulo: Hucitec, 1996. 
No primeiro contato com Rotterdam encontramos uma sociedade extremamente organizada, que apresentava, oficialmente, diversas possibilidades de relação com - espaço, o que, nesse momento, parecia levar a uma vida mais democrática e livre.

Durante o diálogo com o lugar, tudo ○ que pensávamos como possibilidade de ação, de alteração dos elementos de seu espaço físico, esbarrava nos limites de seus mecanismos de controle. Aquela organização que se mostrava libertadora revelou-se opressora.

Estávamos chegando de São Paulo, onde vivemos a constante invenção de possibilidades na sua construção que pode ser compreendida como liberdade, mas que acreditamos servir, também, como forma de dominação.

o que é controle e o que é liberdade, afinal?

Se existe uma oposição entre o que pode significar liberdade e controle de acordo com os diferentes pontos de vista, é porque algo liga todos nós e faz com que seja possivel atuar em país estrangeiro.

Partindo dessa contradição, interviemos. Alteramos os relógios das estações de trem e das vias principais da cidade, acrescentando a eles um segundo ponteiro de hora. Ao dificultarmos a leitura de seus horários, propusemos a desordem temporal do cotidiano daquele lugar. Percebemos que a mais sutil interferência nos referenciais de comunicação de Rotterdam poderia causar um estranhamento revelador da sua própria condição.

Convidado, pouco tempo depois do "Festival Mídia Tática", para participar do projeto "Gear Inside" 95 , na Holanda, o Contrafilé aos poucos pôde ir aprofundando o seu entendimento desse processo de investigar um determinado contexto e responder às tensões pre- 
sentes nele. No texto escrito pelo grupo, como forma de refletir sobre a experiência, percebe-se um componente muitas vezes presente nas investigaçóes-ações propostas pelos coletivos analisados e que complexifica ainda mais a atuação a partir da escala I:I: a relação entre a dimensão local e global da luta.

A intervenção do Contrafilé foi sugerida por um holandês que acabou ficando amigo do grupo. Ele explicou que na Holanda tudo era tão controlado ${ }^{96} \mathrm{e}$ as pessoas eram, em geral, tão submissas ao controle que, se os relógios oficiais da cidade fossem mudados para uma hora absurda, certamente pensariam que eles estavam certos, e não elas. Esse mesmo "informante" e outros com os quais o grupo conversou, também explicaram que lá qualquer ideia transformadora é logo cooptada pelo Estado como, por exemplo, o empréstimo de bicicletas: você usa uma bicicleta, deixa ela em um determinado ponto da ciclovia, e outros podem pegá-la, assim como você pode pegar outra, e assim por diante; modelo que antes era vivido de forma orgânica e informal. Nessas conversas com diversos holandeses, o grupo percebeu que a relação direta entre "cooptação de ideias" e "controle", confunde as pessoas, a ponto de deixarem de acreditar que aquilo que sentem, fazem e inventam faz parte delas, para acreditar que thes foi "dado, cedido, designado, oferecido, doado, atribuído" por um "poder abstrato", principalmente pelo poder do Estado.

O contato com aquela realidade e o esboço de um pensamento crítico que tentava entender como uma sociedade aparentemente tão "perfeita e ordenada", fazia com que as pessoas ficassem tão perdidas, fez com que o Contrafilé trouxesse de volta para casa a apreensão de que "a realidade" é uma camada que precisa ser cons" tantemente desmistificada a partir daquilo que o corpo sente como 
tensão produtiva; e de que é possível intervir a partir desse princípio, mesmo nas situaçóes aparentemente mais "distantes" e mais adversas. Vejo nessa capacidade de desmistificação, o próprio exercício duplo de familiaridade-estranhamento. Esse exercício enquanto ato de aproximar-se e afastar-se, tendo o corpo e seus atravessamentos como referenciais, possibilita, por sua vez, que a experiência do comum se concretize.

\section{Estranhar o próximo, aproximar o distante}

A conexão profunda com o lugar, o "pé na experiência", é compreendida pelos coletivos como pré-requisitos fundamentais, na medida em que permitem uma criação que expande o espaço - seja ele mental ou material - para pensar e atuar sobre um determinado aspecto ou situação da vida social. Por que, então, atuar em "espaço estrangeiro" (entendendo estrangeiro não como um lugar que não é o seu de nascimento, mas como aquele com o qual não existe uma proximidade a priori)? O exercício cotidiano que leva ao tipo de subjetividade política que estamos tentando captar é justamente o de reafirmar para si e para o mundo, a cada momento, o estranhamento em relação ao "próprio lugar", assim como a proximidade com o "lugar outro". É essa espécie de treinamento corpóreo-sensível, o que leva a elaborar um tipo de comunicação urbana que, como diz o antropológo Massimo Canevacci, tem como condição:

[...] a de querer perder-se, de ter prazer nisso, de aceitar ser estrangeiro, desenraizado e isolado, antes de poder reconstruir uma nova identidade metropolitana. O desenraizamento e o estranhamento são momentos fundamentais que - mais sofridos do que 


\begin{abstract}
predeterminados - permitem atingir novas possibilidades cognitivas, através de um resultado "sujo", de misturas imprevisiveis e casuais, entre níveis racionais, perceptivos e emotivos, como unicamente a forma-cidade sabe conjugar (Canevacci, 2004, p.I5).
\end{abstract}

Walter Benjamin desenvolve bem essa ideia no ensaio "O Flâneur": a cidade seria um labirinto e o flâneur o sujeito que sai de casa, todos os dias, como se viesse de longe -, tentando descobrir o mundo no qual vive, olhando para tudo como se jamais tivesse visto, percebendo a humanidade "ao mesmo tempo presente e ignorada" (Benjamin, I989, p. 85-236). Para Roberto Da Matta, esse "perder-se na cidade" leva a "estranhar as regras sociais familiares e assim descobrir (ou recolocar, como fazem as crianças quando perguntam os 'porquês') o exótico no que está petrificado dentro de nós pela reificação e pelos mecanismos de legitimação" (I978, p. 23-35).

A viagem é como a do xamã: um movimento drástico onde, paradoxalmente, não se sai do lugar. E, de fato, as viagens xamanisticas são viagens verticais (para dentro ou para cima) muito mais do que horizontais, como acontece na viagem clássica dos heróis boméricos. Enão é por outra razão que todos aqueles que realizam tais viagens para dentro e para cima são xamãs, curadores, profetas, santos e loucos; ou seja, os que de algum modo se dispuseram a chegar ao fundo do poço de sua própria cultura. Como consequência [isso] conduz a um encontro com o outro e a um estranhamento (id. ibid., p. 23-35).

Portanto, a atuação em espaço estrangeiro no tipo de trabalho aqui analisado, só faz sentido se partirmos dessa compreensão de que, 
se o próximo é sempre matéria-prima de um estranhamento que liberta, o distante pode então ser matéria-prima de uma familiaridade que amplia. É provavelmente por uma crença nessa postura que o movimento cultural, chamado "movimento de movimentos" ${ }^{97}$ por alguns autores ${ }^{98}$, desembocou em inúmeros deslocamentos (inclusive dentro da própria cidade e, por que não dizer, de si mesmo), parcerias e na constituição de um corpo comum coletivo cujo princípio emerge da diferença, o que dá força a essa geração de lutas. Toni Negri e Michael Hardt, em seu livro "Multidão: Guerra e Democracia na Era do Império", descrevem esse movimento simultâneo no qual a subjetivação (distanciamento do outro e aproximação de si) e a produção do comum (distanciamento de si e aproximação com o outro) evidencia a forma de organização da multidão em sua busca de uma alternativa em relação ao "corpo político global do capital":

Nosso ponto de partida é o reconbecimento de que a produção de subjetividade e a produção do comum podem formar, juntas, uma relação simbiótica em forma de espiral. Em outras palavras, a subjetividade é produzida através da cooperação e da comunicação e, por sua vez, esta subjetividade produzida vem a produzir novas formas de cooperação e comunicação, que por sua vez produzem nova subjetividade, e assim por diante. Nessa espiral, cada movimento sucessivo de produção de subjetividade para produção do comum é uma inovação que resulta numa realidade mais rica. Talvez devamos identificar nesse processo de metamorfose e constituição, a formação do corpo da multidão, um tipo fundamentalmente novo de corpo, um corpo comum, um corpo democrático (Hardt e Negri, 2005, p. 247-248).

97. Justamente porque a dimensão "familiar", a "comunidade", se dá a partir da diferença e da multiplicidade. Não é um movimento em bloco, com uma ideologia, palavras de ordem, etc., como na lógica dos partidos e movimentos do século XX. Ao contrário, o que dá sentido ao "movimento de movimentos", é aprender com a riqueza das diversas estratégias locais inventadas no embate com o capitalismo contemporâneo, a desumanização do próprio homem, as desigualdades sociais, etc.

98. Como, por exemplo, Brian Holmes e Marcelo Expósito, amplamente citados nesta dissertação. 
O desenvolvimento de saberes locais e singulares, por um lado; e a criação de dispositivos para que as trocas ocorram a partir de uma "escala referencial comum", por outro, torna visível o pêndulo entre o local e o deslocado operando em uma territorialização e desterritorialização constante. Uma das questôes mais instigantes das práticas artísticas situadas é justamente o desenvolvimento de uma espécie de saber não excludente que parte de situações reais, nas quais a produção coletiva e compartilhada de dobras, que singularizam e marcam a diferença no espaço social, éo que efetivamente produz a experiência do comum.

\section{Um agir que conecta}

A própria visão de carreira está em cheque. Quer dizer, tal como foi visto até aqui, o que era uma carreira de um artista, em que ela se sustentava, em que ela se apoiava, como ela se desenvolvia, enfim, os vários processos. $\mathrm{A} \mathrm{im}^{-}$ portância do disco nisto, a importância dos meios de $\mathrm{co}^{-}$ municação nisto, da televisão, de tudo isso, a importância do show business de um modo geral, enfim, tinham estes clássicos, estas entidades clássicas da produção cultural, [...] era nisto que se sustentava a ideia, o conceito de uma carreira propriamente. Hoje não é só. Não é mais propriamente nessas colunas que uma carreira se sustenta. Portanto, não é mais propriamente uma carreira como era visto antes. É uma série de outras coisas. É um conjunto de fragmentos de várias coisas que vão constituindo o agir do artista (Gilberto Gil). 
Não à toa, inicio esse último movimento do trabalho com uma citação de Gilberto Gil a respeito da figura do artista mais como um "agir" do que como uma "entidade clássica". Assim como o fluxo de que fala Basbaum, esse agir do qual fala Gil, que articula fragmentos na diversidade, reverberou nos princípios e ações desenvolvidos pelo Ministério da Cultura de 2003 a 20ı, quando Gil era o titular da pasta. Apesar de ser necessária uma análise mais aprofundada sobre as relações existentes entre as práticas discutidas neste trabalho e o Ministério da Cultura, no período mencionado, o que não farei aqui, é certo que houve uma influência mútua entre eles.

$\mathrm{Na}$ década em que se difundiram práticas coletivas que repensam noções de identidade e autoria, e criam novas mídias e for mas de inscrição e circulação de seus trabalhos em rede, a esfera estatal, ao menos no que diz respeito à cultura, não só olhou para o que estava acontecendo e aprendeu com isso, como criou dispositivos no intuito de fomentar ainda mais esses debates e movimentos. Esses dispositivos mencionados, na forma de editais públicos de vários tipos (para repasse de recursos, residências artísticas, interaçóes estéticas entre artistas e comunidades, criação de redes, promoção de seminários, etc.), tiveram um eixo condutor transversal que perpassava as ações do Ministério e que pode ser percebido na imagem já mencionada e presente na fala de Gil, quando diz que a "utopia digital brasileira" estaria na compreensão de que "a cabaça do berimbau tem a ressonância da antena parabólica" ${ }^{9}$. Muitos poderiam ser os exemplos citados dos encontros que se tornaram possíveis a partir desse princípio de transversalidade espaço-temporal operando por trás de toda uma política pública de cultura.

O mais relevante a mencionar, no entanto, é que no período de 200 I a 20IO, uma efervescência cultural originada de conexôes

99. Ver capítulo 1. 
entre realidades diversas tornou-se possível, por muitos motivos, sendo o apresentado acima um deles. Esse processo desembocou em práticas e reflexôes que acionavam os "espaços do comum" na contemporaneidade, não apenas como resultado da "criatividade coletiva", mas também de um processo de qualificação dessa "coletividade" como "atualização de tudo aquilo que somos". Como diz o Colectivo Situaciones:

\begin{abstract}
A comunidade merece então uma nova atenção. Fá não como excentricidade de um passado que resiste a morrer, mas sim como uma dinâmica de associação e produção comum com muita vigência política e cheia de ambivalências... Uma comunidade percebida sem apriorismos nem folclorismos (que obstacularizariam a compreensão dos modos através dos quais o comunitário se reinventa). A comunidade é movimento, portanto, um esforço por atualizar o comum, e o comum é sempre o não absolutamente realizável, é uma universalidade aberta, não aferível em sua plenitude. A comunidade é sempre, por isso, um devir, uma tentativa, um avanço (Colectivo Situaciones, 2006, p. 213).
\end{abstract}

Quando temos a oportunidade de entrar em contato com, ao menos, um conjunto de discussões, imagens, textos, das práticas aqui apresentadas, o que vemos é a formação de um "território existencial" ${ }^{\prime \circ o}$ no qual cada fragmento carrega uma sobreposição inusitada de tempos e espaços, conectando-os e "explodindo", assim, o espaço liso do presente. Mais do que discutir as práticas como "arte", interessa, portanto, entender esse agir que conecta e o que acontece, a par-

100. Segundo Félix Guattari e Suely Rolnik, “Os seres existentes se organizam segundo territórios que os delimitam e os articulam aos outros existentes e aos fluxos cósmicos. 0 território pode ser relativo tanto a um espaço vivido, quanto a um sistema percebido no seio do qual um sujeito se sente 'em casa'. O território é sinônimo de apropriação, de subjetivação fechada sobre si mesma. Ele é o conjunto dos projetos e das representações nos quais vai desembocar, pragmaticamente, toda uma série de comportamentos, de investimentos, nos tempos e nos espaços sociais, culturais, estéticos, cognitivos" (Guattari e Rolnik, 2005, p. 388). 
tir disso, com a questão da "autoria". O GAC desenvolve essa questão em seu livro, no capítulo denominado "Metodologias" (2009, p. I82):

\section{La Cuestión del Autor}

- Sobre la idea de propiedad intelectual vs. creación colectiva y conocimiento compartido.

- El carácter anônimo de determinadas producciones.

- La autoría de una determinada acción-intervención o imagen se reconfigura según el contexto y según los agentes involucrados en construcción. No hay un autor, sino múltiples identidades enunciadoras seguin cada caso.

- La no-firma como estímulo para la reapropriación. [...]

As implicações do entendimento que o GAC tem de autoria, parecem claras em sua reflexão: a potência circulatória do anúncio acontece, sobretudo, em decorrência da insurgência de um corpo que se faz anônimo para tornar-se público e que estimula, assim, o aparecimento da multiplicidade. Vera Pallamin, em ensaio no qual analisa o trabalho da Frente 3 de Fevereiro, constrói a imagem de uma coletividade organizada, inscrevendo uma outra "espessura" no social. Segundo ela, a bandeira com a frase:

'Zumbi Somos Nós'tor, situada no estádio, mostra-se a partir das mãos de um corpo coletivo, de seus movimentos mutuamente compreensivos e coordenados que a estendem em posição de evidência. Ela se apóia nesta vontade. Assim posta, ela eclode, de modo silencioso e no meio do alvoroço do entretenimento, uma espessura

101. "Zumbi Somos Nós" é a frase estampada em uma das bandeiras feitas pela Frente 3 de Fevereiro para intervir em espaços da cidade, evidenciando de forma artística os conflitos gerados pelo racismo presente na sociedade brasileira. 
de ordem ética e política, sob incontornável contraste com aquela atmosfera geral de alheamento (Pallamin, 2007, p. 192).

Ofutebol é uma situação exemplar e potente, em que se expressa a ideia de igualdade social e racial e, ao mesmo tempo, se revelam os preconceitos mais arraigados da cultura ocidental e a naturalidade com que aceitamos, reproduzimos e perpetuamos estereótipos racistas (Frente 3 de Fevereiro, 2007, p. 65) (roz $^{\text {ro }}$ Em fevereiro de 2006 participamos de uma ação de resistência organizada pelo Movimento dos SemTeto do Centro (MSTC), em conjunto com grupos artísticos de São Paulo. Esta ação apoiava a ocupação do edifício Prestes Maia, com mais de 2400 famílias, a qual estava com sua reintegração de posse marcada. Neste contexto, instalamos a bandeira Zumbi Somos Nós na fachada do edifício (Frente 3 de Fevereiro, 2007, p. 107).

A “espessura que eclode", mencionada pela autora, parece ter a ver com a inscrição de uma imagem capaz de espacializar as transversalidades que nos constituem, já que "No interior da sociedade e no interior de cada um agita-se a efervescência dessa coexistência de modos, mundos, relações, concepções, que não são contemporâneos" (Martins, 1996, p. 26).

[...] quando inserida no topo do edifício, segundo uma duração mais longa [do que no estádio], 'Zumbi Somos Nós' torna-se um 'selo' a positivar a verificação em curso do princípio da igual-

102. Fragmento da peça Futebol, criada em 2005 pela Frente 3 de Fevereiro, baseada em entrevista com Noel Carvalho. 
dade, sendo operado por aqueles grupos sociais. Estampada na paisagem urbana, seu empenho incluiria o de ser um amplificador das açöes ali sendo travadas por reconbecimento moral e subsidios públicos. Nestes termos, vế-se como os modos de sua espacialização e entrecruzamentos sensiveis alteram sua tessitura político-estética (Pallamin, 2007, p. 192).

A autora se refere acima ao edifício Prestes Maia situado no centro de São Paulo e ocupado em 2002 por integrantes do Movimento dos Sem-Teto do Centro (MSTC). Abandonado há cerca de doze anos, passou a abrigar 468 famílias. Com o intuito de apoiar a luta para conversão definitiva do edifício em habitação social legalizada, vários coletivos artísticos passaram a criar intervenções simbólicas que, de alguma forma, trouxessem à tona o caráter "residual" presente naquela situação, ou seja, toda a dimensão inconclusiva, inacabada, o descompasso de tempos presente em nossa história social, cultural e política.

\section{[...] Enfim, tudo depende do nosso olhar e dos gestos individuais ou coletivos de todos. Zumbi Somos Nós, todos os que procuram converter a violência em uma resistência simbólica em prol da coletividade, rein- ventando as formas de convivência na nossa prática social (Frente 3 de Fevereiro, 2007, p. II).}

A bandeira da Frente 3 de Fevereiro, colocada no edifício Prestes Maia, no final de 2006, traz à tona essa convivência de tempos em um tempo-espaço muito preciso, tornando impossível ignorar o conflito ali existente. Instalando-a exatamente na noite anterior 

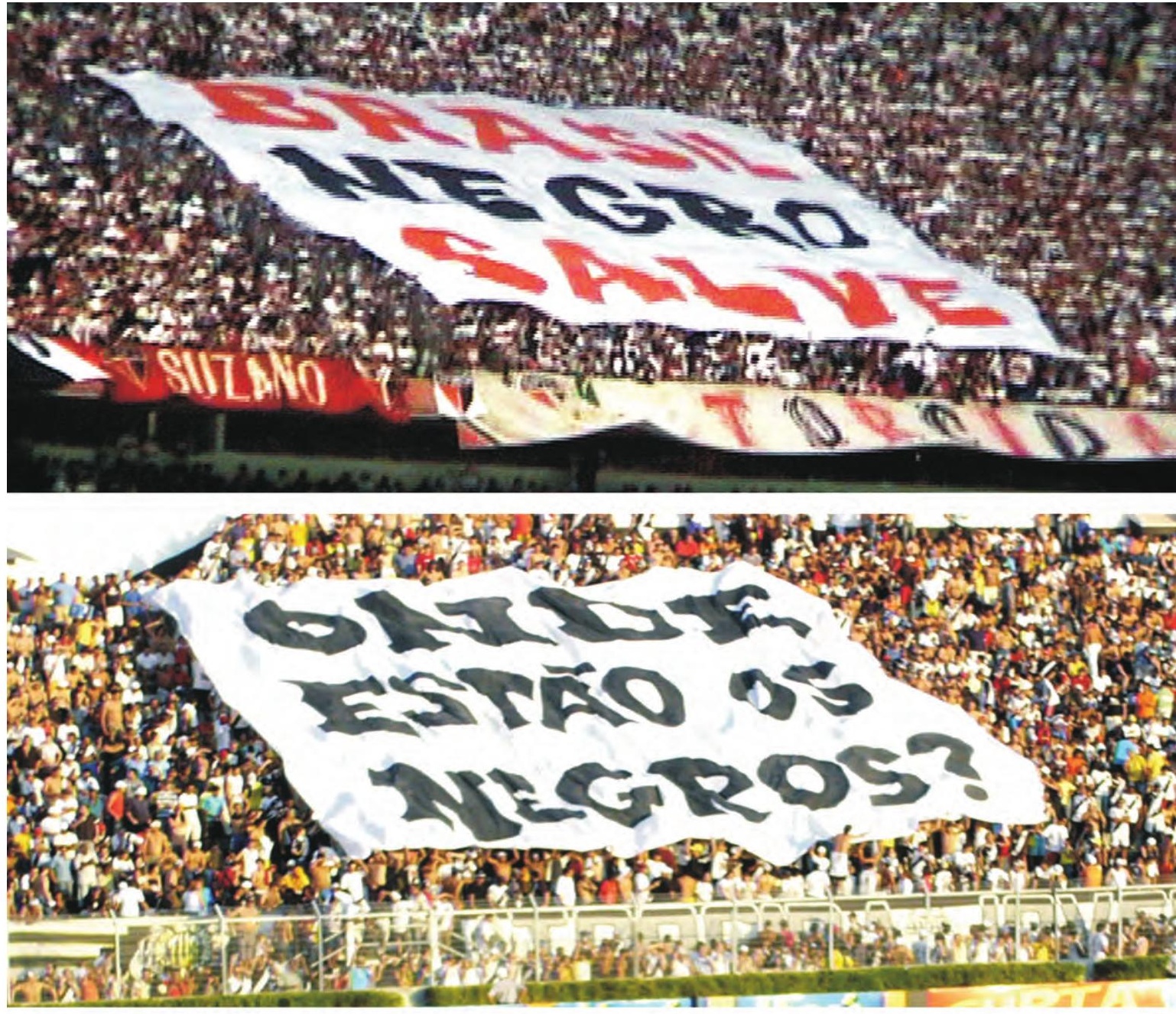

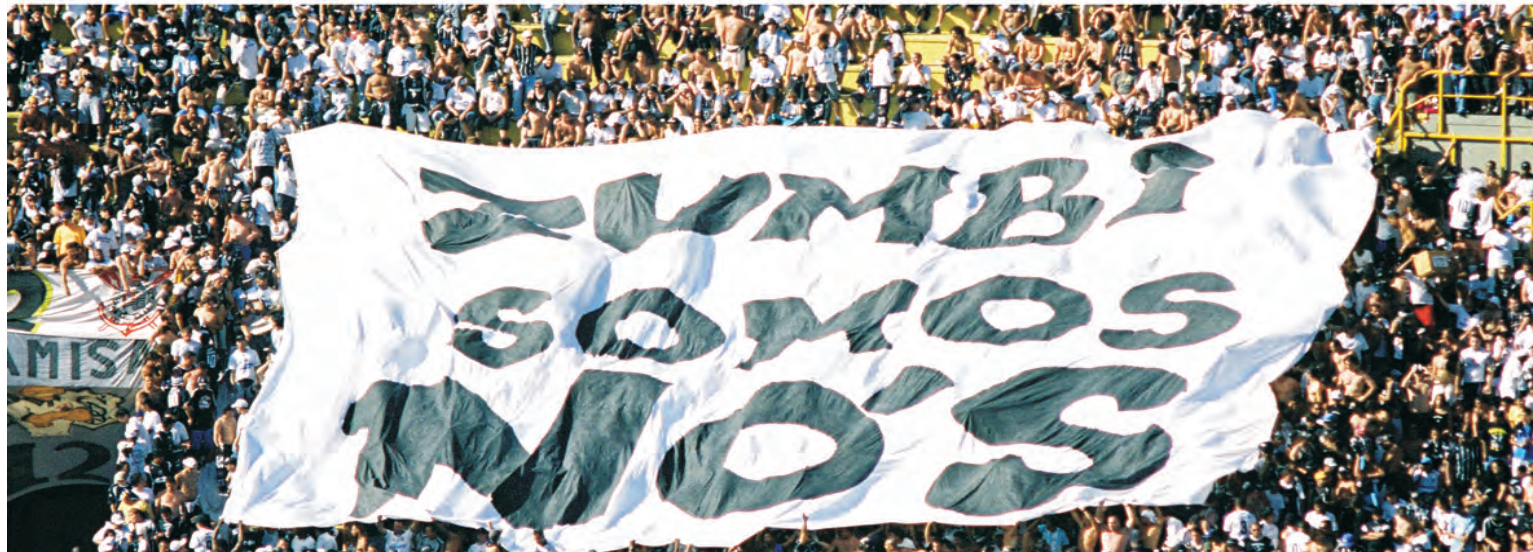
(3)

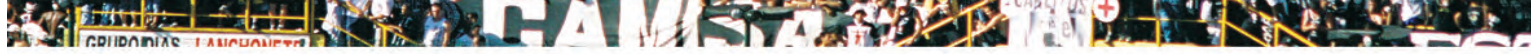

Bandeiras da Frente 3 de Fevereiro em diferentes estádios e na ocupação Prestes Maia

(2004-2006). As imagens produzidas pela Frente 3 de Fevereiro trazem, em geral, camadas sobrepostas e em disputa. 


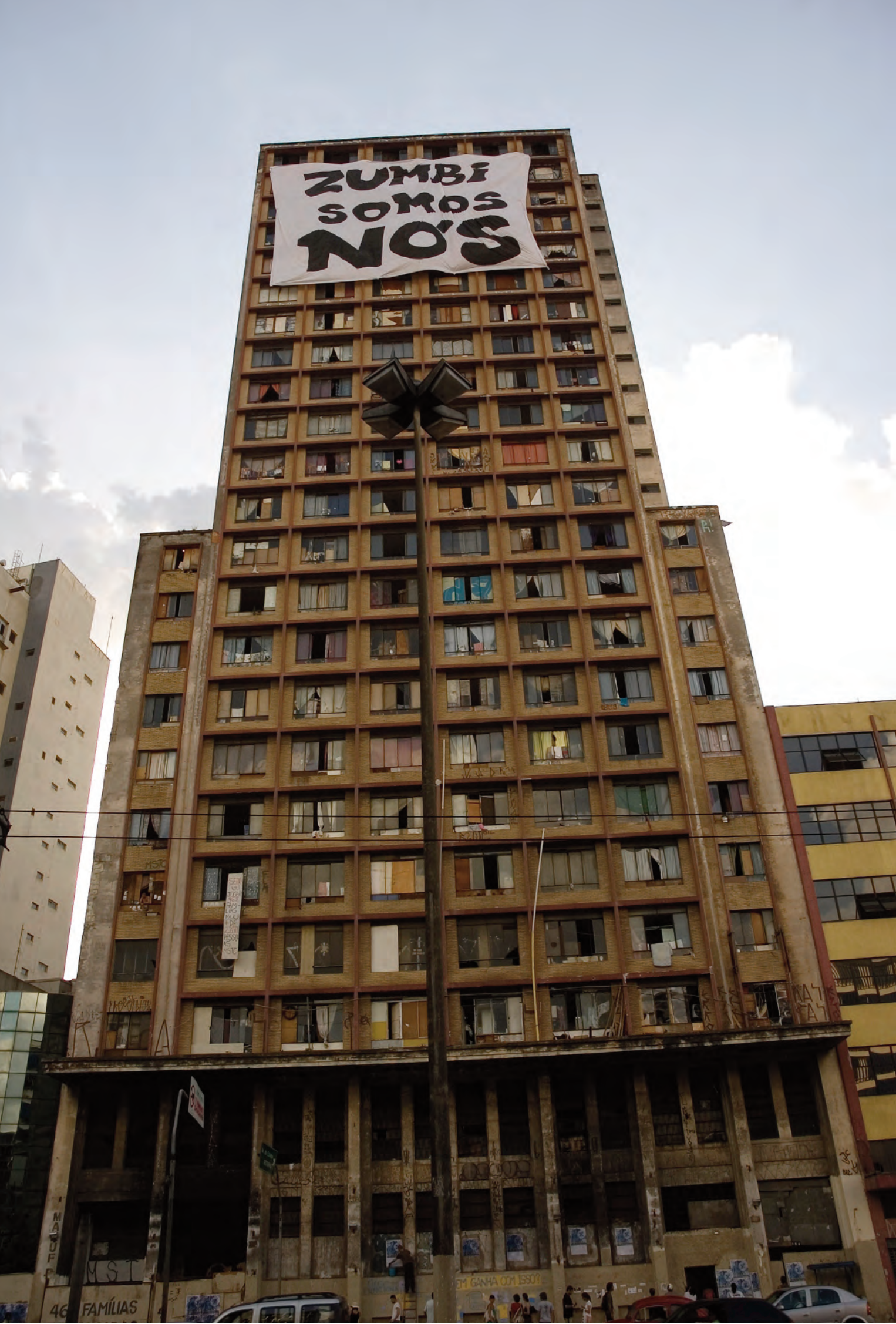

Y 
à iminente ordem de despejo dos moradores (que depois se mostrou apenas mais uma ameaça), a Frente sabia que, além de inscrever o gesto estético-político na própria cidade, seria possível inscrevê-lo na grande mídia, o que de fato ocorreu. Em diversos telejornais, em cadeia nacional, excedendo qualquer possibilidade de redução pelo discurso oficial, estava ali a bandeira com a sua mensagem, condensando como estratégia e como conteúdo muitas das discussões, reflexôes, dúvidas, idas e vindas que tiveram - e ainda têm - como foco a relação entre os coletivos artísticos e os movimentos sociais. A perspectiva étnica da "ancestralidade", que a reduziria a tempos e espaços específicos, folclóricos e distantes, dá lugar a uma situação muito mais complexa, na qual não é a identificação somente com “Zumbi”, e muito menos com um "Zumbi” estático, o que está em jogo, mas o auto-reconhecimento como "quilombola" e, assim, com todo um "território simbólico de existência".

No projeto "Quilombo Brasil" ${ }^{\circ 03}$, desenvolvido pelo coletivo Política do Impossível (PI) em parceria com a Casa de Cultura Taină ${ }^{104}$ entre 2009 e 2010 , também vemos a tentativa de construir uma compreensão aberta, mais uma indagação do que uma resposta, a respeito de "o que é ser quilombola hoje". Cabe ressaltar que dois integrantes da Frente 3 de Fevereiro fazem parte do PI e certamente isso influenciou e provocou o grupo a levar adiante essa "investigação-ação". Abaixo, em trechos do projeto, textos reflexivos escritos pelos integrantes do PI e conversas travadas entre o coletivo, quilombolas rurais e urbanos e integrantes da Frente, vemos essa complexidade aparecendo.

103. "Quilombo Brasil" (2009-2010) foi um projeto apoiado pelo Prêmio Interações Estéticas: Residências Artísticas em Pontos de Cultura (Minc/Funarte) que possibilitou a realização de seis viagens a diferentes regiões que concentram quilombos do Brasil.

104. O coletivo Política do Impossível trabalha com a Casa de Cultura Tainã desde o início de 2005 e, em parceria com os seus referentes, educadores e gestores, já idealizou e executou diversas ações: festas comunitárias; intervenções urbanas em espaços ligados à memória da escravidão - visando questionar o esquecimento da memória reiterado na sociedade brasileira; rodas de debate sobre intervenção urbana e a possibilidade de atualizar as estratégias do movimento negro através da arte; entrevistas com referentes da Casa de Cultura Tainã e da luta negra. Em todos estes momentos, utilizou diversas linguagens para dar forma aos desejos e potências comuns aos dois grupos. 
No projeto pretendemos expandir e aprofundar espaços de discussão e ação sobre a história e a cultura brasileira através de deslocamentos em diferentes comunidades que participam da luta e identidade quilombola na Rede Mocambos ${ }^{105}$. 2ue situações hoje constituem o marco de luta social e política que ontem foram corporificadas nos quilombos? 2ual a continuidade desta luta? 2uais os seus espaços de intervenção e criação simbólica? Estas são algumas das questões levantadas pelo projeto (PI) ${ }^{\text {ro6. }}$.

Este é um trabalho que tem como foco contribuir para o embate simbólico fundamental em um processo contemporâneo de auto-representação. Acreditamos ser nesta dimensão simbólica de um território possivel que diversas confïgurações de lutas e vidas podem se encontrar e se identifícar. $\boldsymbol{E}$ é assim, através do encontro entre a potência da arte e a da política, que toma corpo a nossa busca por compreender o que é ser quilombola boje (PI) ${ }^{107}$.

As expressões da cultura popular praticadas em espaços urbanos que se auto-denominam quilombos, são vividas a partir de uma referência tanto espiritual quanto política. Na ocupação popular Zumbi dos Palmares, em São Luís do Maranbão, encontramos ruas batizadas coletivamente com nomes de

105. "[A Rede Mocambos] É uma rede de negros e negras de âmbito nacional. Conectando através das tecnologias da informação e comunicação comunidades quilombolas rurais e urbanas. Para isso buscamos parcerias de diversos segmentos para que de forma colaborativa e coletiva possamos reunir diferentes programas, projetos e ações voltados para o desenvolvimento humano, social, econômico, cultural, ambiental e preservação do patrimônio histórico e memória dessas comunidades." Fonte: http://oca.idbrasil.org.br/wiki2/index.php/Rede_Mocambos.

106. Trecho do projeto que resultou no trabalho "Quilombo Brasil" do coletivo Política do Impossível em parceria com a Casa de Cultura Tainã e Rede Mocambos.

107. Trecho de texto reflexivo escrito pelo coletivo Política do Impossível sobre experiência desencadeada pelo projeto "Quilombo Brasil", 2010. Acervo pessoal. 


\section{QUILOMBO BRASIL}

A DISPUTA PELO TERRITÓRIO OULLOMBOLA MOBTLIZA O COLETIUO POLITICA DO IMPOSSIUEL E A REDE MOCAMBOS PARA UMA CRIACÁ̃O COMUM. MẢO APENAS GEOGRÁFICO DU FÍSICO, ESTE É UM TERRITÓRIO A SER IMUENTADO HO PASSADO, MO PRESEMTE E MO FUTURO.

DESTA BUSCA SURGIU UMA SÉRIE DE CINCO DOCUMENTÁRIOS

QUE INUESTIGAM O OULLOMBO BRASIL: BRIACADEIRAS DE TERREIRO

OCUPANDO A CIDADE: PRÁTICAS ANICESTRAIS RESISTIMDO Ả INSTALAÇÃO

DE UMA BASE DE LANCAMENTO DE FOGUETES: RUAS BATIZADAS

COM OS NOMES DE LUIZA MAHIN, NEGRO COSME, NELSOH MANDELA:

A ESCOLA DE ERISINAMENTOS DE MAE PRETA; UM GERADOR DE LUZ

OUILOMBOLA. UM OLHAR IMERSQ. AFETIUO E IMPLICADO

Realizaçăo

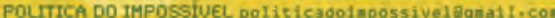

MOCAMBOS.MET nocanbos. net

CASA DE CULTURA TAIMÁ

leămin.COR - Documentário.Extras

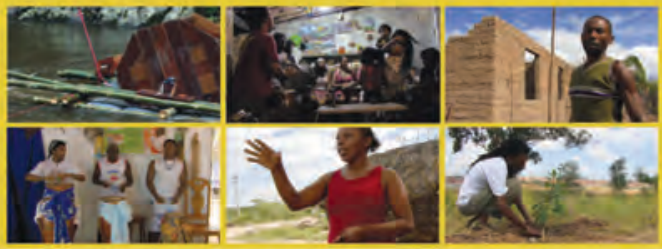

Hower Cultura funarte $=$

Esta iniciativa integra o Prémio Interaçóes Estéticas - Residéncias Artisticas em Pontos de Cultura

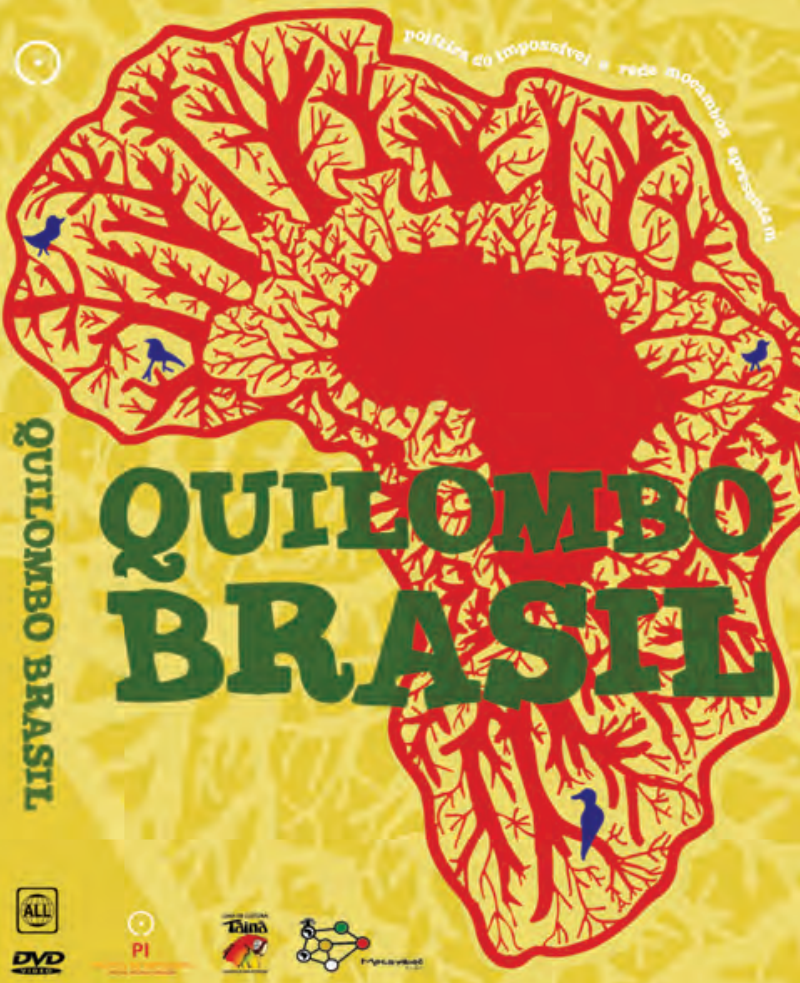

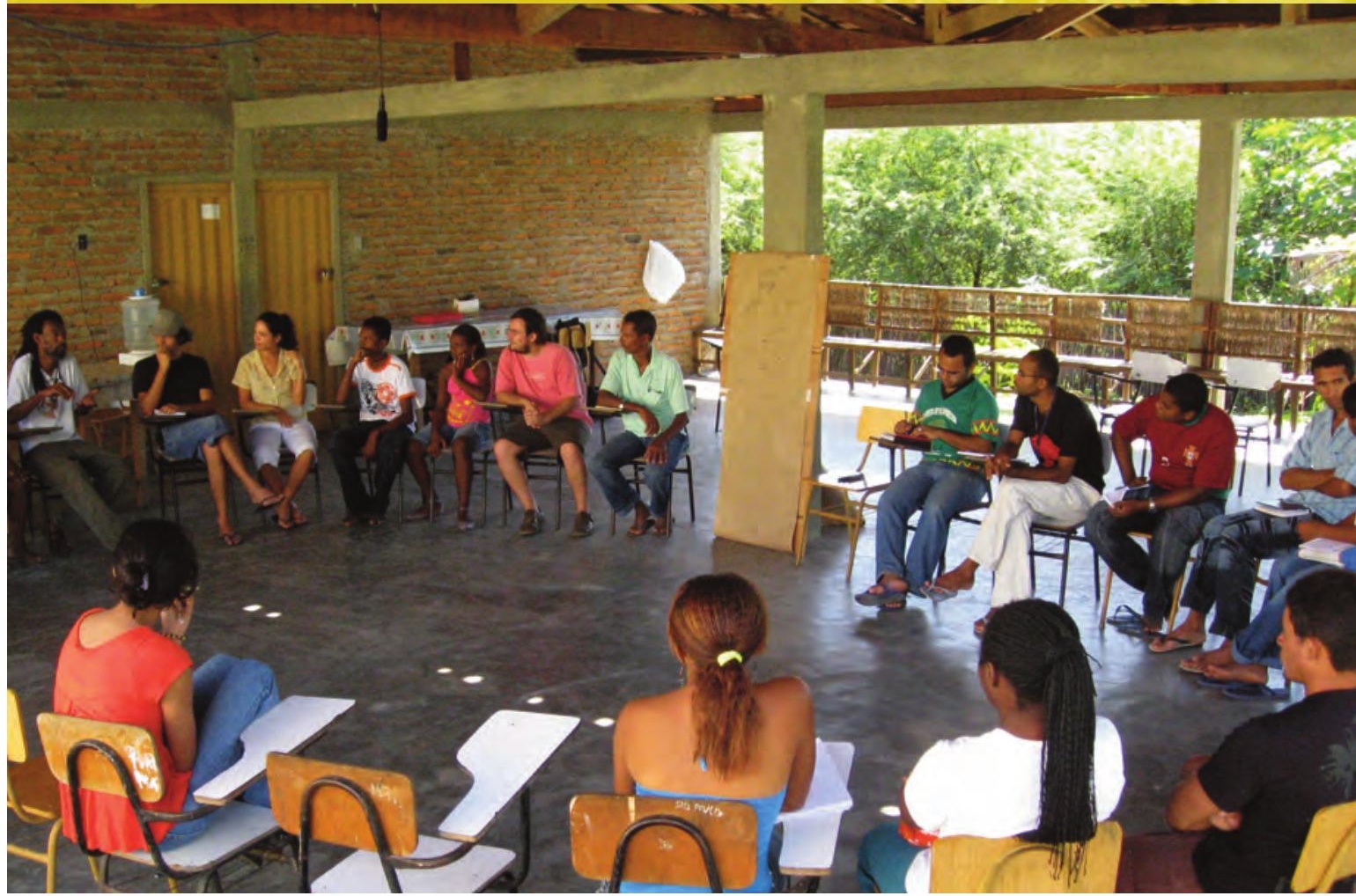

Projeto “Quilombo Brasil”, PI, 2009-2010 
lideranças negras (Rua Luiza Mabin, Av. Negro Cosme etc.). Assim, cotidianamente o bairro convoca uma tradição de resistência a valores e processos dominantes que ainda boje confinam muitas das práticas sociais numa ambiguidade e até mesmo em uma bipocrisia quanto a sua própria cultura. Por outro lado, como disse Cida, liderança do quilombo rural de Conceição das Crioulas, 'queremos uma educação que aproxime nossas crianças delas mesmas $e$ de sua cultura, não uma educação que as distancie de si mesmas.' Hoje, lideranças jovens como Cida [Maria Aparecida Mendes] e seu irmão Antônio [Mendes], estão interessados em re-aprender sobre os terreiros, os orixás, a religiosidade africana enquanto em Olinda, entre becos, ações de criminalização e racismo policial, a comunidade do Coco de Umbigada se depara com dilemas conbecidos por quem vive em grandes cidades, especialmente por aqueles que vivem de expressões culturais urbanas de resistência: autonomia $x$ dependência institucional; espaços físicos reduzidos, distanciamento em relação a uma vida auto-sustentável, potencialização da vida x precarização da vida. Quando olbamos sob o prisma de uma discussão quilombola atualizada, ficam evidentes algumas questóes: se no campo a terra é fundamento intrínseco da luta, na cidade a luta está nas dinâmicas culturais, nos embates sociais e na diversidade de situações e campos de forças com os quais é necessário lidar todos os dias. Por 
outro lado, mesmo no campo a questão da terra não é apenas física, mas também simbólica - a luta pela terra está intimamente ligada à auto-identifïcação com um território de vida tanto diacrônico quanto sincrônico. Isto aproxima o quilombo rural de um território de produção cultural, tal qual o é, como raiz, o quilombo urbano. Se ai a questão da terra como espaço físico no qual se produz uma economia conectada também à subsistência parece ter se perdido, éjustamente por isso que se cria um território de intersecção entre pessoas que se conectam pelo e através do simbólico. Assim, na dimensão simbólica de um território possivel, estas duas confỉgurações de lutas e vidas se encontram e se identifícam. E está nesta inquietação a nossa busca por compreender o que éser quilombola boje (PI) ${ }^{108}$.

A gente pretende formar o pessoal com uma consciência muito crítica do que é a matriz africana. Não é só a beleza, o esplendor das festas. Em uma sociedade como a nossa não é fácil ser mulher, não é fácil ser candomblecista. Isso leva o pessoal a um conflito muito grande. $E$ é preciso que a gente se fortaleça mesmo, espiritualmente, fisicamente, no poder da palavra, porque o enfrentamento é contínuo (Mãe Lúcia de Oiá) ${ }^{\text {rog. }}$

2ual o formato que a gente compreende? É a gente pensar o futuro que a África que está aqui com a gente pode nos ajudar a construir. Por isso que eu

108. Idem.

109. Depoimento ao PI de Mãe Lúcia de Oiá, Escola de Ensinamentos de Mãe Preta, RecifePE, 2009. In: Quilombo Brasil (DVD), PI, 2010. 
acho importante ter referências, como é o tambor, o Baobá, porque são simbologias que temos que ter para nos agarrar. Isso tem que ser a nossa escola. É aprender a aprender. $\dot{E}$ assim que se ensina (TC) ${ }^{\text {ro. }}$

$O$ decreto 4887 traz a perspectiva muito nova que é a idéia de território náo como terra, mas como um campo simbólico de representação, com a idéia de interdependência. Se a comunidade não existe, aquele território não existe. E aí entramos num problema a mais na atual legislação do INCRA, que remove do contexto o termo 'território' e passa a usar 'terras e áreas'. Ou seja, esse campo do simbólico se esvazia muito (Rosana Meneses) ${ }^{\mathrm{II}}$.

Com o acontecimento das coisas, algumas pessoas aprenderam que a gente tem que ser de paz, não pode procurar encrenca, tem que fic ar quietinbo, no canto, acomodado, por que Deus quer assim. Eu fui uma das que começou a procurar encrenca. E eu procurava vó... Ai vó: Pois é, meu pai já dizia que ia ser desse jeito, pois vão em frente! E ela transmitiu para a gente essa força de saber que não vai ser possível reconquistar o nosso território, fortalecer a nossa cultura, transformar esses meninos em criaturas criticas, sem conflito (Maria Aparecida Mendes) ${ }^{112}$. O nosso povo, eu digo pelo meu, é segurança, a maio-

110. Antonio Carlos Santos da Silva (TC) é um importante referente da luta negra contemporânea, criador da Casa de Cultura Tainã em Campinas, articulador da Rede Mocambos e parceiro contínuo, desde 2005, do PI e da Frente 3 de Fevereiro. Aqui, trechos de conversa realizada no projeto "Quilombo Brasil" com quilombolas de Conceição das Crioulas, Pernambuco, 2009. Estavam presentes também todos os integrantes do PI. 111. Rosana Menezes é historiadora, estuda quilombos e participou de várias conversas com quilombolas do Vale do Ribeira (SP), integrantes da Casa de Cultura Tainã e grupo PI no projeto "Quilombo Brasil", 2009.

112. Em conversa realizada com integrantes do PI e Casa de Cultura Tainã em viagem do projeto "Quilombo Brasil" ao quilombo Conceição das Crioulas, Recife, Pernambuco, em 2009. 
ria é segurança. Você vê em que nível miserável fïcou o nosso povo: corta o cabelo, tira os dreads, tira a roupa africana, coloca aquela roupinba azul e vai guardar os estabelecimentos dos bacanas para ter um salariozinho e a vida valendo quase nada (Beth de Oxum) ${ }^{113}$.

Você vaifïcar assim: fulano é branco, fulano é negro? Isso é para pirar. Eu sempre tive isso muito bem resolvido. Eu tenho quatro fillhos, um é mais claro, outro é mais escuro. Eu vou dizer o quê? Você é branco, você é preto, você é quase branco, você é quase preto. Isso fic a para intelectual, com todo o respeito. Na prática, a gente se reconbece, se percebe, se tem identidade e acabou-se, está tudo resolvido (Beth de Oxum, 2009).

2uilombos somos nós, o povo que resiste neste pais, que toca tambor, que faz Coco, Maracatu, Afoxé, são os terreiros, em essência são os terreiros, envolve preto, envolve o povo e acabou-se (Beth de Oxum, 2009).

Todos os quilombos que eu já fui, eles convivem com diferenças, eu não conbeço nenbum quilombo só de negros. Eu não vivo em um quilombo rural, mas me reconbeço quilombo urbano, pela nossa experiência, como acho que aqui é, mas agora qual a nossa compreensão disso? Chegando aqui, em uma ocupação urbana de São Paulo, 'nessa quase cidade, nessa quase favela, onde está todo mundo enlouquecido de cinza, cimento e pedra, loucos para viver um ro- 
mance de novela.' Então, ser quilombola boje acho que passa muito pela consciência de si mesmo, o que eu sou, por que estou aqui. É mais do que simplesmente estar aqui por alguma circunstância que me trouxe aqui. Eu tenbo que dizer: 'Estou aqui por que quero estar aqui, estou aqui logo este é meu lugar, se é meu lugar vai fícar do meu jeito, não importa o quanto me neguem'. Se eu tiver essa consciência, eu começo a fazer os outros pensarem que eu não estou aqui para ser negado. O quilombo traz um sentido de resistência, de liberdade, justamente a possibilidade de ter um mundo diferente do que está aí, onde não tem a negação, onde exista o reconbecimento, a identifícação de um com outro (TC). ${ }^{114}$

Murar as pessoas é não reconbecê-las, é negá-las, é negar o ir e vir, isso sim. Não é memória, a gente está vivendo isso. Isso aqui é o que? É gente de desassentados que foram sendo chutados, chutados, desagregados até parar nisso. Quilombos somos todos nós, então é mostrar isso, esse agora. Quilombo está associado com povoamento, com distribuição espacial e formas de convivência. Resistência são formas de convivência. Quando você bota um muro, você empobrece, você está dizendo que não báformas de convivência com aquele grupo da população, é impossível conviver, ou só na bala. E se eu estou mexendo com isso, eu estou mexendo com quilombos urbanos. A discussão toda é: 'Eu estou em risco'. E se eu estou em risco, eu afasto (Maurinete Lima). ${ }^{115}$

114. Roda de conversa proposta pelo PI a partir da pergunta "O que é ser quilombola hoje?" realizada na Ocupação Mauá, centro de São Paulo, em abril de 2009. Convidados: Maurinete Lima (Frente 3 de Fevereiro), TC Santos Silva (Casa de Cultura Tainã) e Conceição Paganele (AMAR - Associação de Mães e Amigos da Criança e Adolescente em Risco). In: Quilombo Brasil (DVD), 2010. 

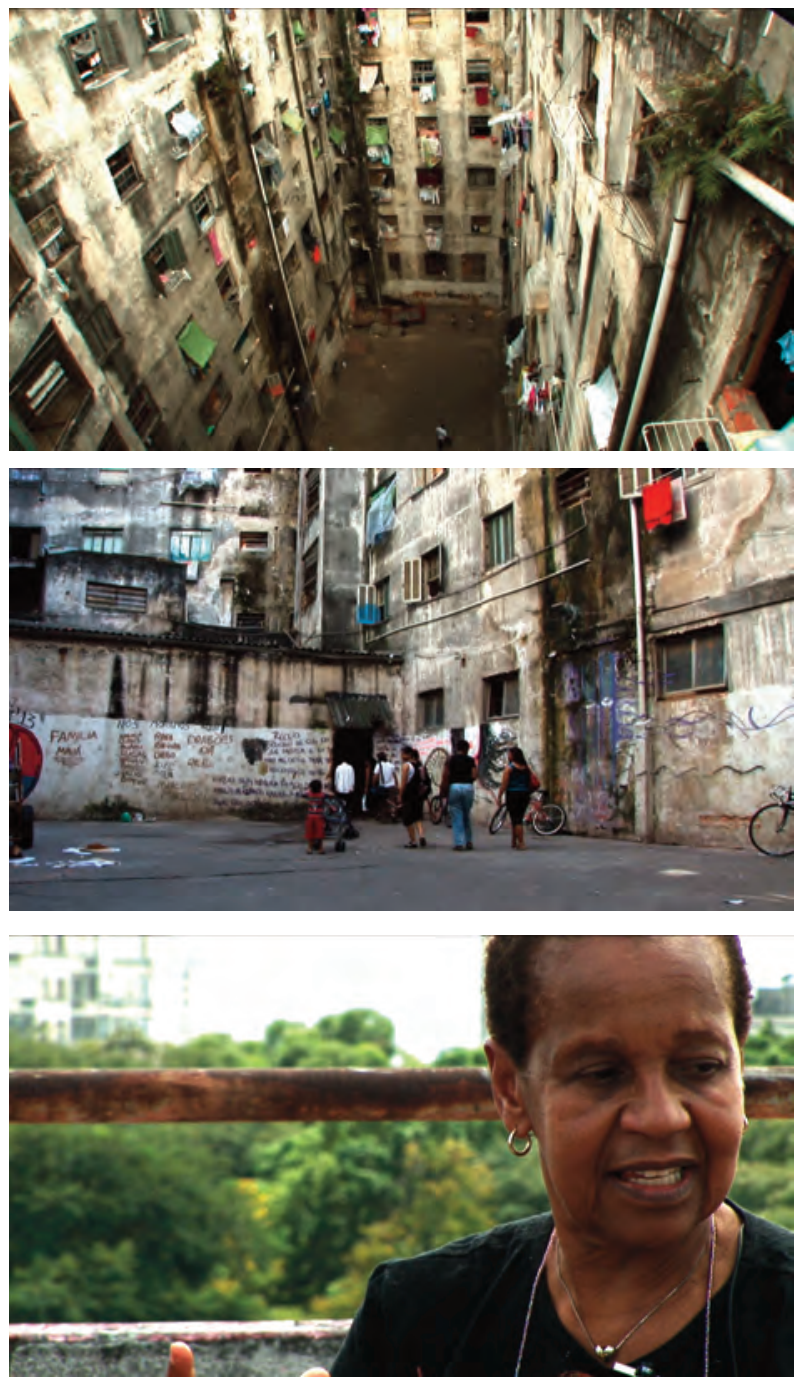

Conversa entre Maurinete Lima, Conceição Paganele e TC no alto da ocupação Mauá, a partir da pergunta disparadora proposta pelo PI: "O que é ser quilombola hoje?”, São Paulo, 2008.
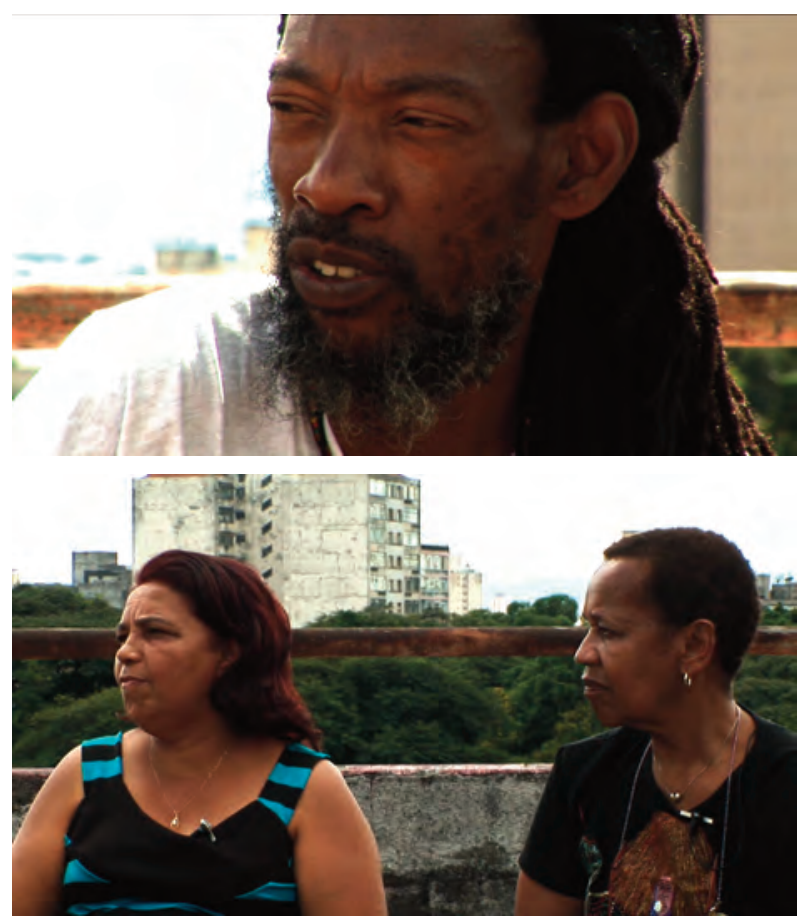
A situação criada a partir da consigna "Zumbi Somos Nós", espacializada no tecido urbano, soa como a imagem do "atlântico negro" (I993), do sociólogo inglês Paul Gilroy, termo inspirado na diáspora negra que se "refere metaforicamente às estruturas transnacionais criadas na modernidade que se desenvolveram e deram origem a um sistema de comunicações globais marcado por fluxos e trocas culturais" (Santos, 2002, p. 273).

Segundo Hermano Vianna:

\begin{abstract}
Inspirado na desterritorialização deleuziana e na não-linearidade da física contemporânea, Paul Gilroy define o 'Black Atlantic' como uma formação rizomática e fractal, colocandose em luta contra a 'trágica popularidade das idéias sobre a integridade e a pureza das culturas' e também contra aquilo que chama de absolutismo étnico (1999).
\end{abstract}

Nesse sentido, existe uma questão que sempre permeia as discussóes da Frente 3 de Fevereiro e que diz respeito a uma produção política que transita entre a afirmação da "identidade" e a experiência da singularidade.

Se, por um lado, muitas vezes aparece pelas vozes dos integrantes a importância de se afirmar como "negro", por outro, a composição do grupo (composto também por japoneses, "brancos", judeus... ou seja, pessoas de "diversas origens"), assim como as imagens produzidas, levam imediatamente a nos questionarmos o que é exatamente "ser negro": é apenas a cor da pele? Eu posso ser negra, mesmo sendo uma "judárabe"?

116. Música presente no CD “O Silêncio”, Arnaldo Antunes, BMG, 1996. 
Inclassificáveis ${ }^{16}$

ArnaldoAntunes - 1996

que preto, que branco, que índio o quê??

que branco, que indio, que preto o quê?

que índio, que preto, que branco o quê?

que preto branco indio o quê??

branco indio preto o quê?

indio preto branco o quê?

aqui somos mestiços mulatos

cafuzos pardos mamelucos sararás

crilouros guaranisseis e judárabes

orientupis orientupis

ameriquítalos luso nipo caboclos

orientupis orientupis

iberibárbaros indo ciganagôs

somos o que somos

inclassifícáveis

não tem um, tem dois,

não tem dois, tem três,

não tem lei, tem leis,

não tem vez, tem vezes,

não tem deus, tem deuses, 
não bá sol a sós

aqui somos mestiços mulatos cafuzos pardos tapuias tupinamboclos americarataís yorubárbaros.

somos o que somos

inclassificáveis

que preto, que branco, que índio o quê? que branco, que índio, que preto o quê? que indio, que preto, que branco o quê?

não tem um, tem dois, não tem dois, tem três, não tem lei, tem leis, não tem vez, tem vezes, não tem deus, tem deuses, não tem cor, tem cores,

não há sol a sós

egipciganos tupinamboclos yorubárbaros carataís caribocarijós orientapuias mamemulatos tropicaburés chibarrosados mesticigenados oxigenados debaixo do sol 
Para o antropólogo Osmundo de Araujo Pinho (2003), a associação entre o "Movimento Negro Moderno" e os chamados "Novos Movimentos Sociais", foi o que abriu a possibilidade de redefinição das problemáticas do movimento negro como questóes públicas comuns a toda a sociedade:

Um processo marcado pelo redirecionamento de questôes da esfera privada - a cor da pele, o racismo operando no plano das relaçôes interpessoais, a religiāo Afro-Brasileira, o cotidiano imediato e periférico dos bairros negros, etc. - para a arena pública, através da inclusão de discursividades negras, como um novo sujeito, como um pólo ou eixo de articulação de miríades de vozes que se encontram e se cristalizam neste processo de enunciação coletiva.

Assim, se a Frente 3 de Fevereiro parte claramente do discurso racial, no meio do caminho ele é subvertido por essa situação na qual um sujeito múltiplo se apresenta. Porque o principal nas estratégias estéticas e comunicativas criadas pelo grupo, parece ser a criação de legibilidade para o fato de que é essa potência de um corpo pré-colonial que está sendo ativada para a reinvenção do social. Existe, portanto, no uso do Zumbi como metáfora, não apenas uma ideia abstrata, mas uma atualização corporal e espacial da sabedoria dos terreiros, do candomblé, dos orixás. Segundo Araújo Pinho (2003):

O quilombo passa a representar um modelo alternativo de organização da sociedade que desafiou os poderes coloniais e reinventou um mundo africano - no caso de Palmares, banto baseado no trabalho livre, na propriedade comum da terra, em valores tradicionais, holisticos etc. 


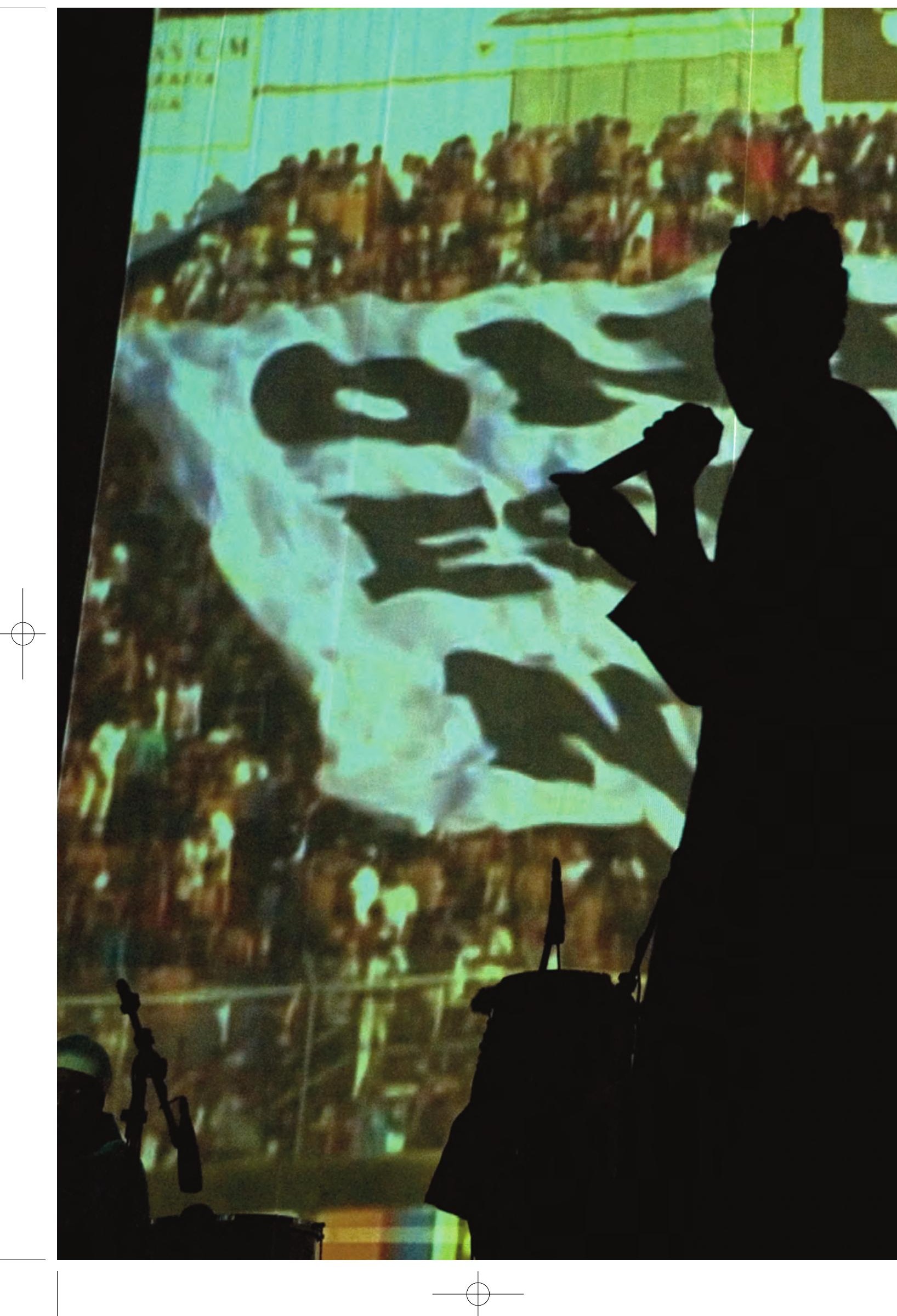




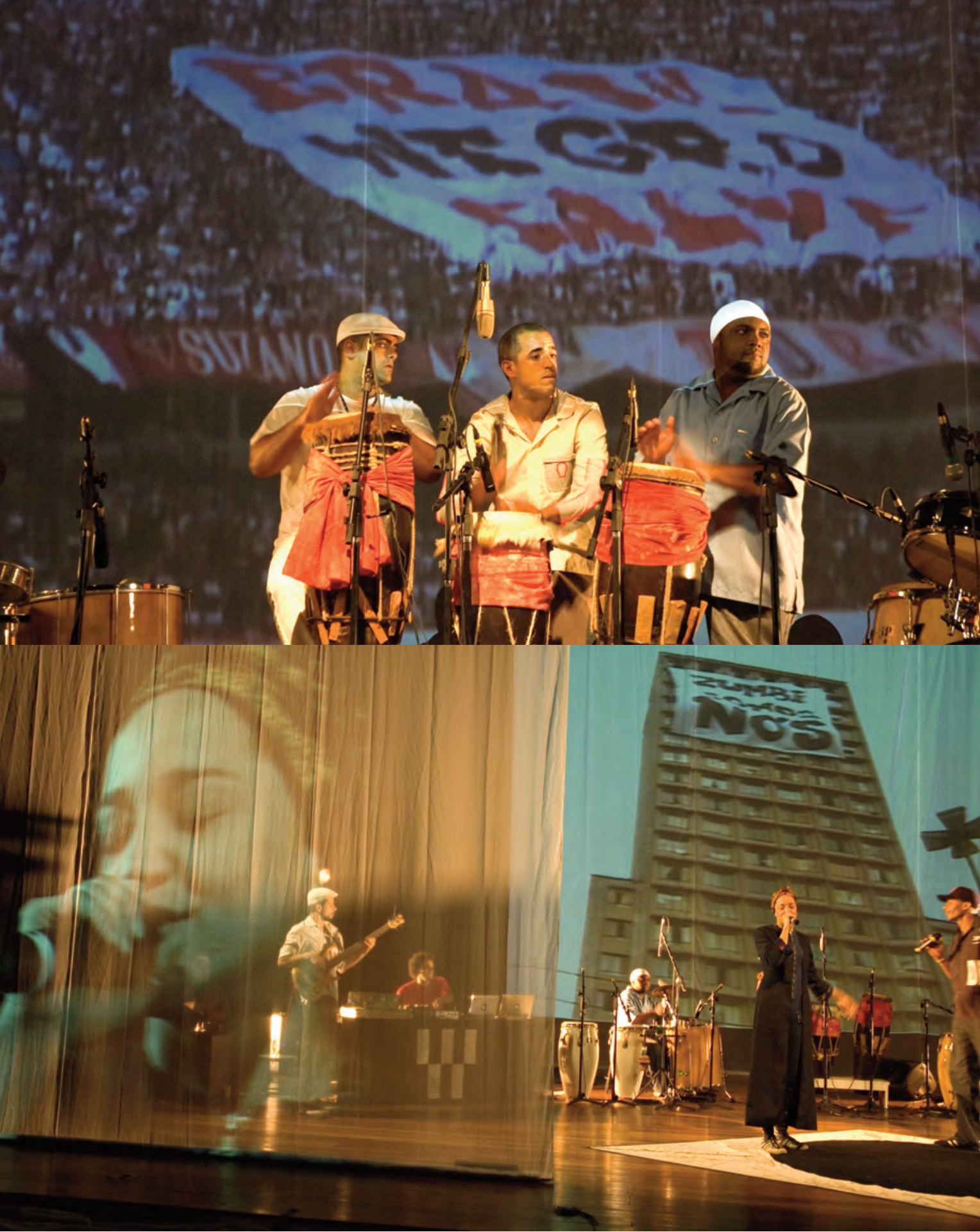

Show da Frente 3 de Fevereiro no qual vemos uma mãe de santo com um rapper e por trás a imagem de uma intervenção urbana. Discutindo com Daniel Lima, integrante da Frente e que fez comigo o projeto gráfico desta dissertação, entendemos que nos shows do grupo existe sempre uma tentativa de re-criar o território urbano com toda a sua transversalidade.

A "colagem" de linguagens artísticas, o apelo ao mesmo tempo ao ancestral e ao contemporâneo, são estratégias que permitem, no palco, vislumbrar a "espessura" presente nos trabalhos realizados na cidade. São Paulo, 2006. 


\begin{abstract}
A Frente 3 de Fevereiro, formada por artistas plásticos, cineasta, designer gráfïco, músicos, bistoriador, socióloga, dançarina, advogada, cenógrafo e atores, nasceu da mobilização desse grupo com um dado de realidade: no dia 3 de fevereiro de 2004, o jovem negro Flávio Sant'Ana, confundido com ladrão, foi assassinado pela polícia militar de São Paulo. [...] Dois meses depois do assassinato [...] nós da Frente 3 de Fevereiro realizamos um ATO simbólico no local do crime - zona norte da cidade de São Paulo-junto com a família do jovem (Frente 3 de Fevereiro, 2007, p. 8-20).
\end{abstract}

Hamilton Cardoso, um dos mais notáveis intelectuais negros do periodo [década de I980], procurou explorar todas as conseqüências políticas do reconbecimento de Zumbi como berói nacional em novembro de 1985 , principalmente aquelas que sinalizam para o aspecto trans-étnico da luta de libertação quilombola, nesse sentido 'resgatar' Zumbi: 'É um fato cultural porque é um fato politico; é um fato político porque rompe com a politica cultural dominante. Reflete, na verdade, outra forma de engajamento político do militante negro nos processo sociais. Revela um ponto de vista bumano, capaz de romper as fronteiras da raça. Arrebentando a geografia da pele e da cor' (Araújo Pinho, 2003) ${ }^{117}$.

É interessante pensar que nestas práticas urbanas criam-se estratégias para inscrever na cidade uma sabedoria ancestral. No

117. Hamilton Cardoso. O Resgate de Zumbi, Cultura e Política.vol.2, no. 4. Lua Nova, 1986, p. 63-67. 
Monumento Horizontal à Flávio Sant'Ana, podemos entender o questionamento da "verticalidade" dos monumentos como uma forma de marcar com o corpo um território autônomo de ação e representação, função cumprida também pelos quilombos como modo de vida e invenção de espaço de resistência política. O que está em jogo é essa subjetividade que se rebela contra a arbitrariedade do "Poder" e inventa - transformando em indício aquilo que poderia ficar eternamente na informalidade ${ }^{\mathrm{II} 8}$-, um contra-espaço, afim de evidenciar onde/como/por que/para que/para quem tal "Poder" é fundado e espacializado.

Em outros trabalhos da Frente, vemos como a discussão que nasce do enraizamento se desloca no sentido da multiplicidade. Convidados em 2006 para ir a Berlim, onde estava acontecendo a Copa do Mundo, para apresentar o espetáculo "Futebol" (no qual trazem à tona diversas situações de disputa pela produção da cidade, vividas nos estádios como potente campo de análise social), a Frente se conectou com grupos locais ${ }^{119}$ no intuito de discutir questões migratórias. Juntos, demarcaram no mapa de Berlim os estatutos diferenciais de circulação dos migrantes pela cidade. Denominaram as áreas da seguinte forma: "áreas onde podem ir", "áreas onde correm perigo", “áreas onde correm perigo de vida", estas chamadas "no go areas" - paradoxalmente, o próprio Estado, oficialmente, reconhece e informa aos imigrantes para não irem em tais áreas, denominando-as desta forma.

\section{Workshop HAU}

No contexto de nacionalismo e euforia que pairava sobre a Alemanba na Copa do Mundo 20o6, desenvolvemos um projeto de intervenção em Berlim tendo 


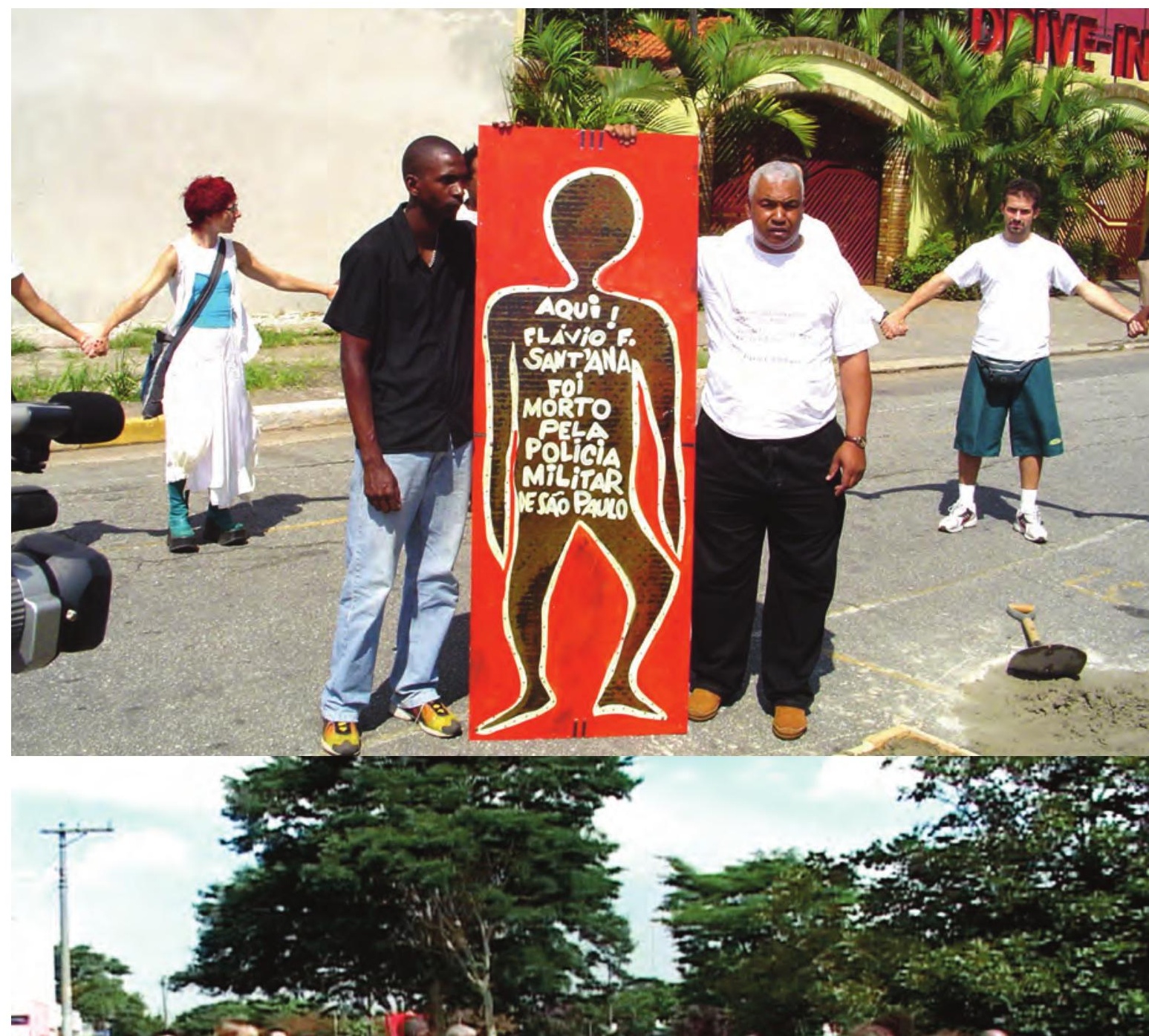

$=0$

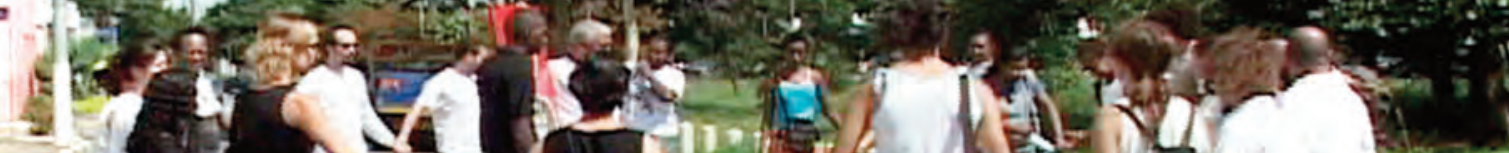
$212^{2}$

Em volta do Monumento Horizontal à Flávio Sant'Ana, a Frente

e colaboradores, em roda, como num ritual de morte, São Paulo, 2004. 


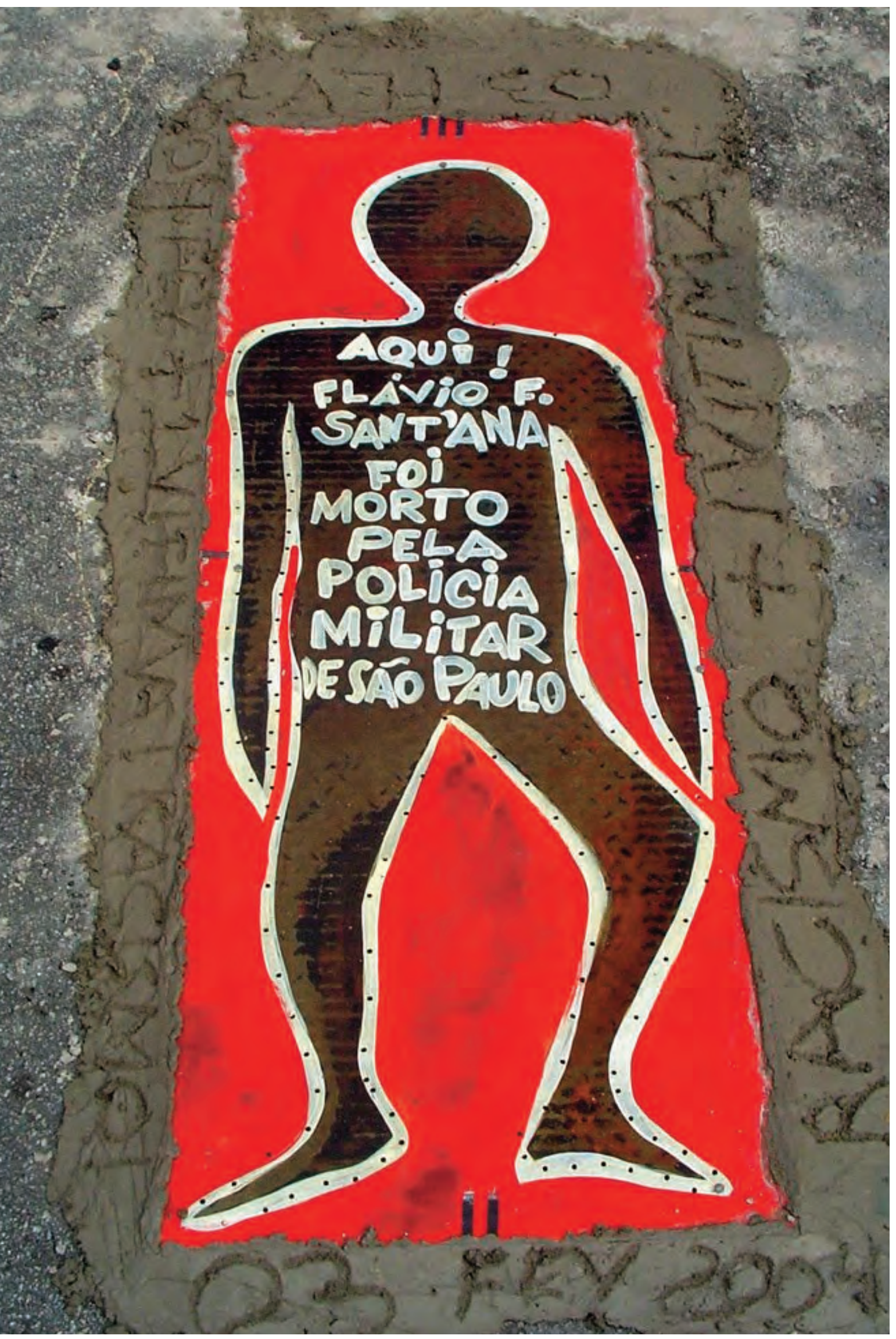

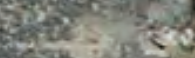

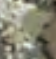

6.:

3. $x$ 

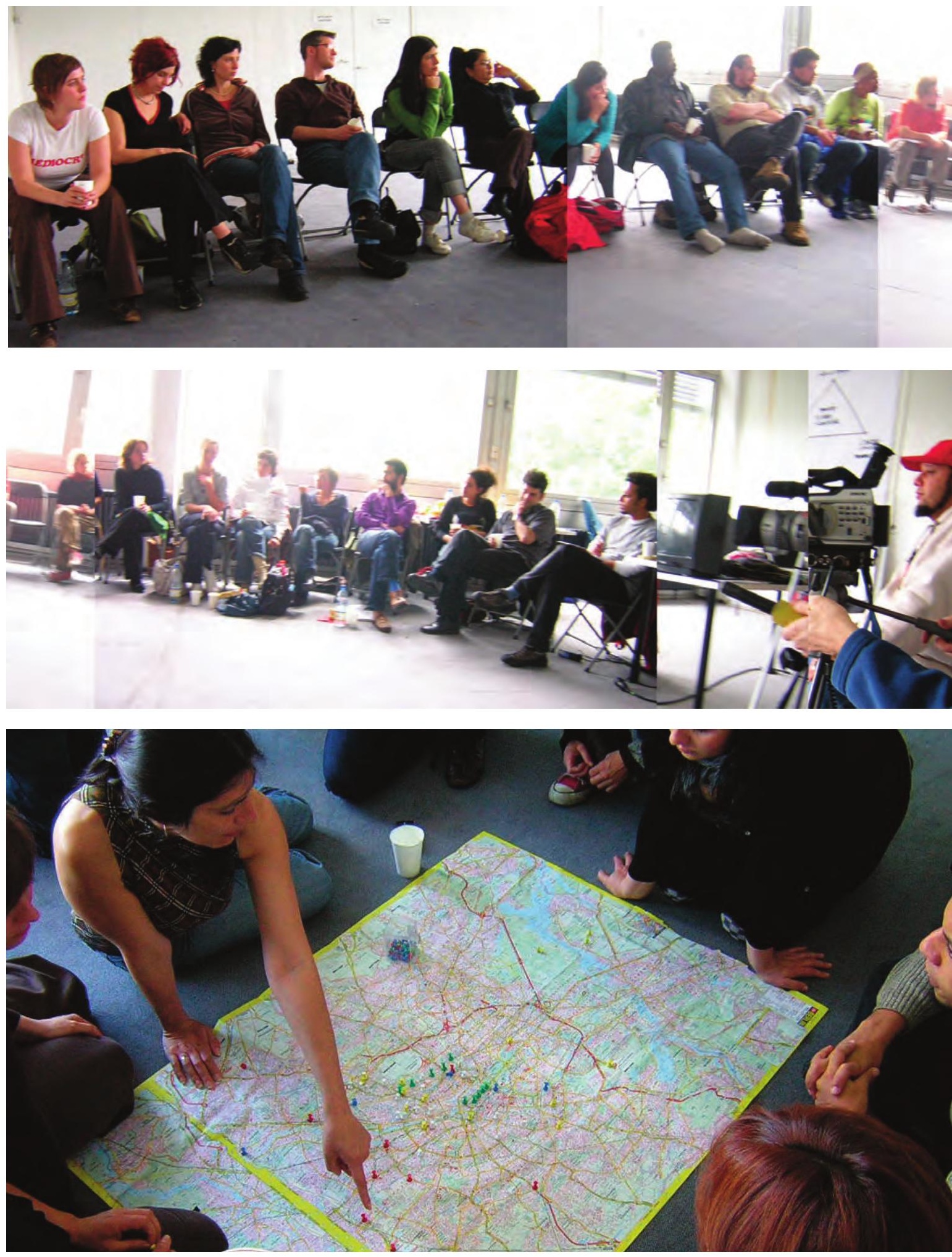

Imagens do workshop proposto pela Frente

para outros coletivos de Berlim, Alemanha, 2006. 


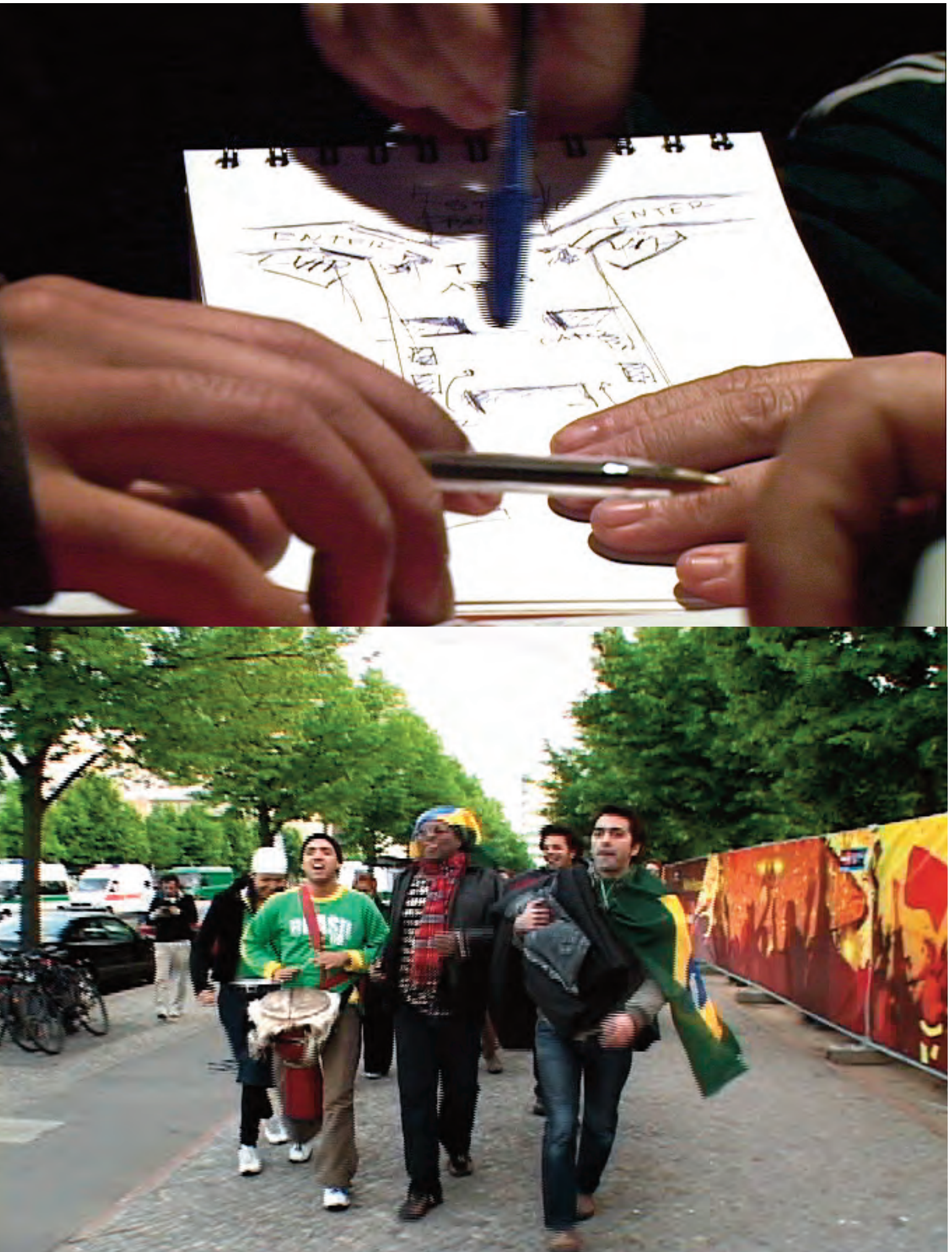

Frente 3 de Fevereiro discutindo qual estratégia usariam para entrar na festa de abertura da Copa do Mundo com uma bandeira gigante e imagem do grupo passando pela barreira de segurança do evento, tocando um samba, Berlim, 2006. 


\begin{abstract}
como foco a situação do imigrante na Europa. Desenvolvemos um workshop junto com grupos de arte e ativismo da Alemanha, no qual a relação do imigrante com a comunidade européia funcionou como ponto-chave para a discussão do racismo em contraposição à imagem construída por eventos como a Copa do Mundo, nos quais diferenças políticas, socioeconômicas e culturais parecem ser superadas sem conflito (Frente 3 de Fevereiro, 2007, p. 94).
\end{abstract}

Espalharam placas pela cidade, iguais às placas oficiais, com a frase "Know go areas" Go Area", demarcando as fronteiras invisíveis e, ao mesmo tempo, questionando a aceitação pela população nativa, migrante e pelo próprio Estado desta forma de compreensão do espaço. A partir desta ação, decidiram fazer uma bandeira com essa mesma frase e desenrolá-la, com câmeras ao vivo de redes de televisão do mundo todo, na festa de abertura da Copa do Mundo, a "Fan Party".

Criaram toda uma estratégia de passagem pela barreira de segurança que dava acesso ao local da festa (vemos aqui um evidente saber circulatório): entraram tocando um "sambinha", "disfarçados de brasileiros". A polícia alemã simpatizou com eles. Pediu, em inglês, que abrissem a bandeira - que de tão grande era carregada por mais de cinco pessoas. Um dos integrantes do grupo respondeu, também em inglês: "É que depois fica muito difícil para fechar". O policial, no clima do samba, autorizou a passagem. No momento em que a festa começou, com toda sua pompa e glamour, televisionada para todos os cantos do mundo, eis que vemos a bandeira com a frase "Know go Area" sendo aberta. Fica no ar por alguns segundos, chegando a bilhōes

120. Que mudava o sentido de "áreas proibidas" para algo como "conheça as áreas proibidas". 


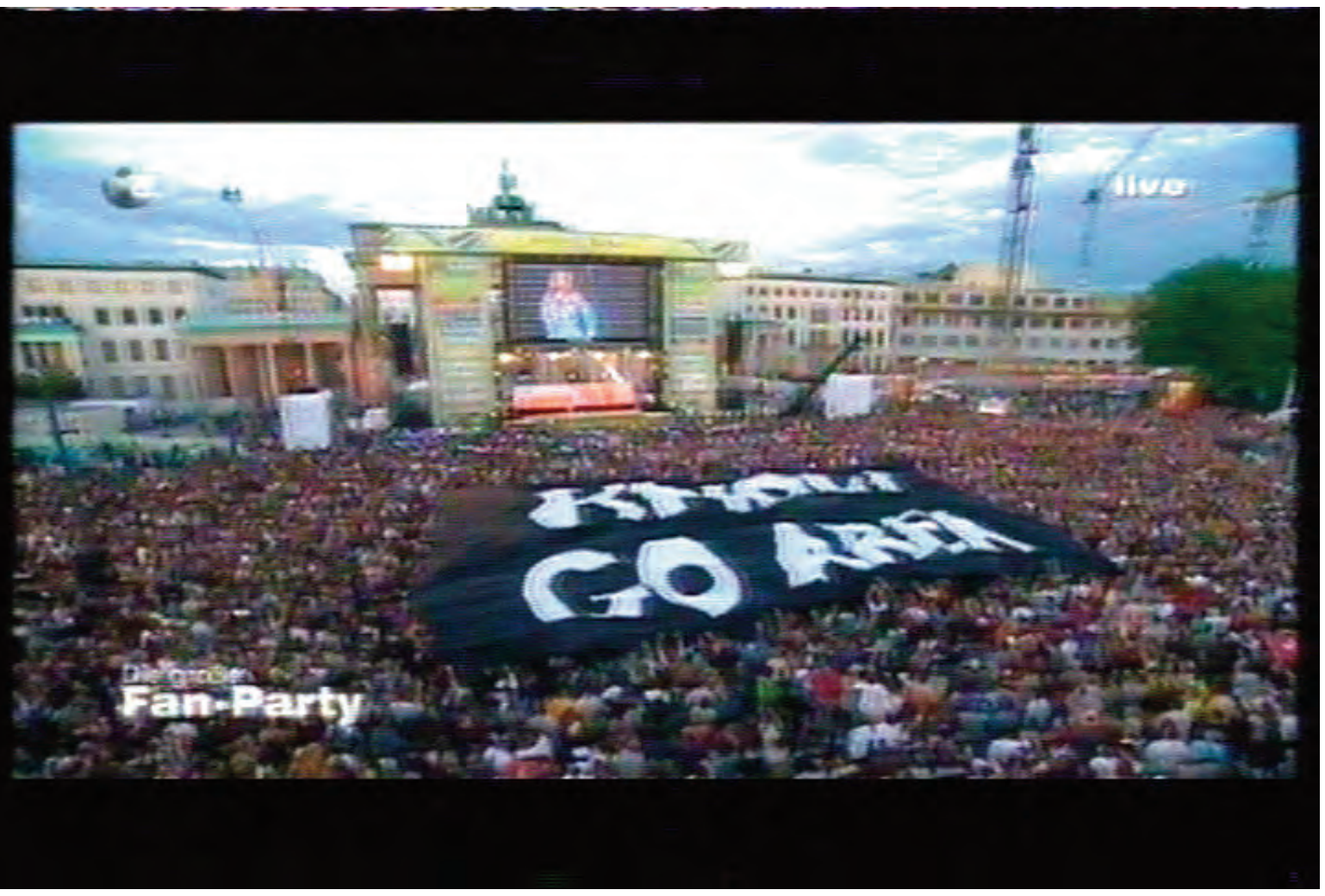

Bandeira feita pela Frente 3 de Fevereiro e coletivos de Berlim na festa de abertura da Copa do Mundo de 2006, Berlim, Alemanha. 

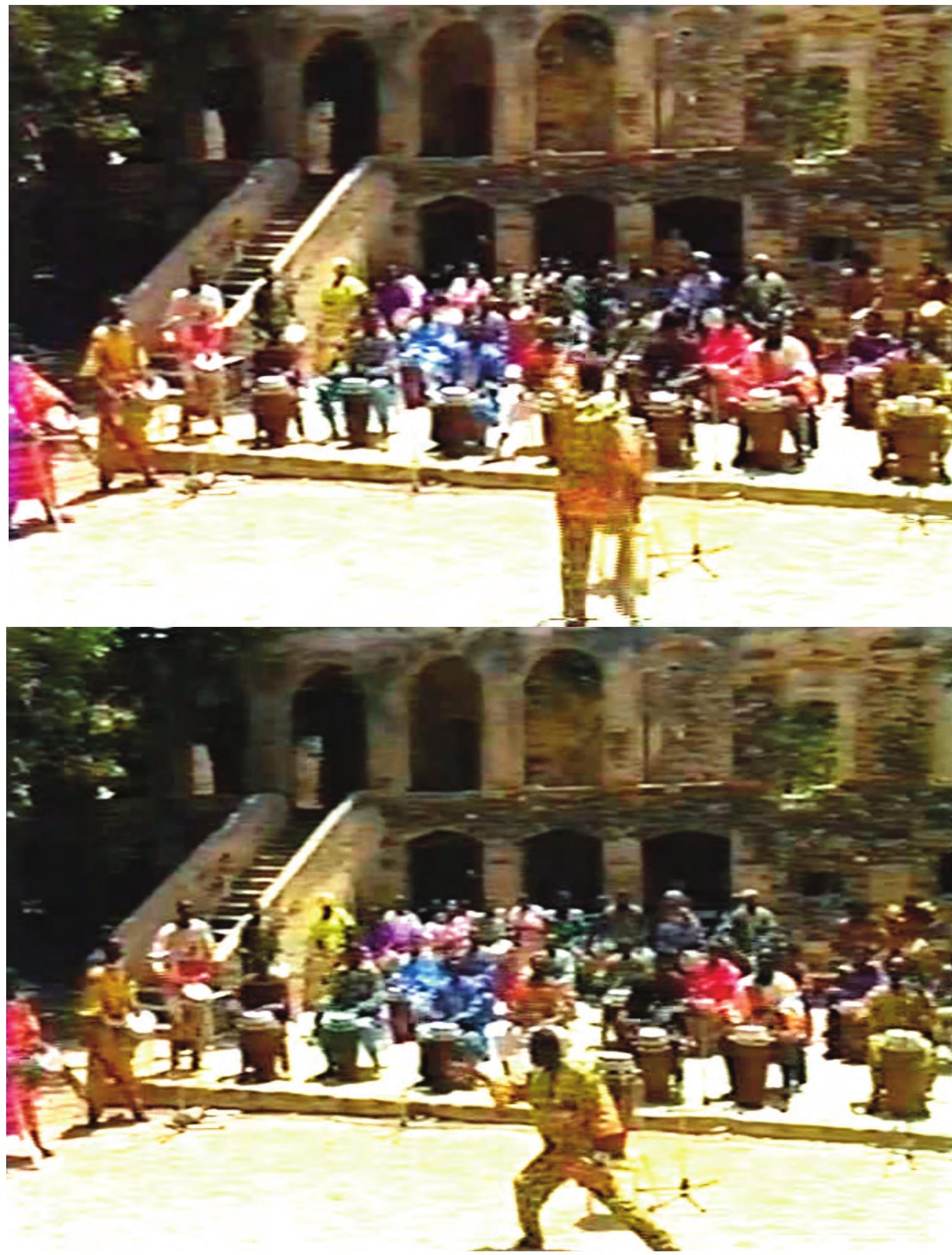

Intervenção através do som de tambores do músico DouDou N'diaye Rose e sua orquestra na llha de Goré, um dos lugares que mais mandou negros escravizados para o mundo. 
de pessoas. Nessa imagem, fica clara a simultaneidade de tempos presente em uma situação que deveria ser prioritariamente asséptica: o tempo do grande espetáculo sofre a intervenção do tempo das pessoas invisíveis e de sua desobediência que "suja" a imagem televisiva ao dar carne a ela.

Termino com uma sequência de acontecimentos que evidenciam o desejo de agenciamento e atualização de saberes pré-coloniais. Em 2007, integrantes do coletivo Política do Impossível e Casa de Cultura Tainã, viajaram ao Festival de Arte Negra (FAN), realizado em Belo Horizonte, com o intuito de conversar com DouDou $\mathrm{N}^{\prime}$ diaye Rose, músico, percussionista e mestre griot africano ${ }^{121}$. $\mathrm{O}$ que motivou o encontro foi um vídeo documentário de uma ocupação musical orquestrada pelo maestro DouDou na "Casa dos Escravos" da Ilha de Goré - porto de onde partiram milhares de negros escravizados para as Américas. A imagem de uma ocupação física e simbólica feita através dos tambores, ativando aquele espaço, reverberou nos integrantes dos dois grupos. O vídeo da ocupação em Goré foi também um dos trabalhos - além dos escraches do GAC - que inspirou a ocupação simbólica realizada na Fazenda Jambeiro (Campinas), organizada pela Casa de Cultura Tainã, o coletivo Política do Impossível, Jongo Dito Ribeiro e outros grupos artísticos. Jambeiro foi uma fazenda colonial escravocrata e hoje é um espaço público abandonado.

Trechos da conversa com DouDou N'diaye Rose ${ }^{122}$ :

TC: Aquele momento na casa dos escravos, na Ilha de Goré, para a gente foi muito importante, uma referência muito forte. Como foi 
isso para os que participaram? O que os levou a tocar na Ilha de Goré?

DouDou: Comecei a tocar o "tam tam" quando tinha 9 anos. E por que eu fui a Goré? Pois quando aprendi a tocar o "tam tam" queria marcar a passagem da casa dos escravos. Eu poderia fazer esse regis' tro em vários lugares, na beira do mar, na minha região, ou ainda em outras regiōes, mas eu preferi Goré. Se há a Martinica, a Ilha da Reunião, outros continentes, é porque eles passaram pela casa dos escravos. [...] É por isso que eu queria mostrar que tudo se passou lá, em Goré.

TC: Esse lugar é um lugar forte, que marca a história do negro em diáspora. Goré é importante para nós também, como símbolo. E ver o tambor tocar ali, pulsar vivo, nos motiva a lutar com a música, com o tambor.

DouDou: Foi para mostrar o primeiro ritmo que tocamos, o ritmo que anuncia a partida dos escravos. O primeiro que eu toquei em Goré foi o ritmo da partida dos escravos. O ritmo se chama "vocês partem, mas não retornam”. Meus parentes estão lá ou acolá. Eles partiram. E não retornaram mais. Mas um dia pode acontecer [...] A gente encontra nossos parentes, mas não somos capazes de reconhecê-los.

TC: A gente se reencontra nos sons dos tambores...

[...]

Tenka: Uma pergunta que tem a ver com todo o processo do Jambeiro, que é sobre a escravidão. As lacunas que o processo de escravidão deixou na África, porque a gente conhece os resultados da escravidão no Brasil, mas a gente não sabe qual é a lacuna que ficou lá... E eu acho que isso é uma ponte interessante.

DouDou: Os africanos, todos os africanos, não estão contentes com 
o que ocorreu no passado. Os colonizadores, eles tinham a força, eles nos colonizaram, nos mostraram sua força, mas ninguém ficou contente com aquilo que fizeram. E felizmente, os africanos sabem perdoar. Se não fosse por isso, em um curto período, muito sangue ia rolar. Porém eles os perdoaram e nós estamos trabalhando para refazer... para plantar a nossa cultura. Eles queriam que nós fossemos escravos, eles queriam que nós perdêssemos nossa cultura. Mas eles não podiam, pois agora, vejam, nossa cultura retorna. Eles não podem partir sem nós. 


\section{BIBLIOGRAFIA GERAL}

Adorno, Theodor. Museu, Valéry, Proust. In: Prismas - Crítica Cultural e Sociedade. Tradução Augustin Wernet e Jorge Mattos Brito de Almeida. São Paulo, Editora Ática, 1997.

Amaral, Rita de Cássia. A alternativa da festa à brasileira. In: Revista Sexta Feira (Antropologia, Artes e Humanidades) $n^{\circ}$. 2. São Paulo, Concepção e realização Pletora Ltda., 1998.

Appadurai, Arjun. Soberania sem territorialidade. Notas para uma geografia pósnacional. Tradução Heloísa Buarque de Almeida. In: Novos Estudos nº 49. São Paulo, 1997.

Arantes, B.F, Otília. Os Novos Museus. In: Novos Estudos CEBRAP n. 31. São Paulo, 1991.

Araújo Pinho, Osmundo. "O Sol da Liberdade": Movimento Negro e a Crítica das Representações Raciais, 2003. In: Revista Rizoma.net/Afrofuturismo, link http://pt.scribd.com/doc/46875356/Afrofuturismo-Rizoma-net, acessado em abril de 2012.

Argan, Giulio Carlo. História da Arte como História da Cidade. Tradução Pier Luigi Cabra. São Paulo, Martins Fontes, 2005.

Basbaum, Ricardo. Perspectivas para o museu no século XXI, 2005. In: Fórum Permanente (on-line). Link:

http://www.forumpermanente.org/.painel/artigos/rb_museus, acessado em abril de 2011.

. O artista como curador. In: Catálogo do Panorama 2001. São Paulo, Museu de Arte Moderna, 2001.

Benjamin, Walter. O Flâneur. In: Obras Escolhidas III. Tradução Hemerson Alves Baptista. São Paulo: Brasiliense, 1989.

Teses Sobre Filosofia da História. In: Walter Benjamin, Coleção Grandes Cientistas Sociais (org. Flávio R. Kothe, coord. Florestan Fernandes). São Paulo, Editora Ática, 1991.

Brandão, Carlos R. A Cultura na rua. Campinas, Papirus Editores, 1989.

Holmes, Brian e Expósito, Marcelo. Brian Holmes entrevistado por Marcelo Expósito, Estéticas de la igualdad, Jeroglífos del futuro. In: Revista Brumaria 5. Madrid, Associacion Cultural Brumaria, 2006.

Brito, Ronaldo. Neoconcretismo - Vértice e Ruptura do Projeto Construtivo Brasileiro. Rio de Janeiro, Funarte, 1985. 
Burger, Peter. Teoria da Vanguarda. Tradução José Pedro Antunes. São Paulo, Cosac Naify, 2008.

Butler, Judith. Que es la critica? Un ensayo sobre la virtud de Foucault. Tradução Marcelo Expósito. In: Revista Brumaria 7. Espanha, Associacion Cultural Brumaria, 2006.

Caldeira, Teresa Pires do Rio. Cidade de Muros: crime, segregação e cidadania em São Paulo. São Paulo, Editora 34/Edusp, 2000.

Canevacci, Massimo. A cidade polifônica: ensaio sobre a antropologia da comunicação urbana. Tradução Cecília Prada. São Paulo, Studio Nobel, 2004.

Carlos, Ana Fanni Alessandri. A mundialidade do espaço. In: Henri Lefebvre e o retorno à dialética (org. José de Souza Martins). São Paulo, Hucitec, 1996.

Carlos, Ana Fanni Alessandri. O Lugar no/do Mundo. São Paulo, Hucitec, 1996.

Colectivo Situaciones. Inquietudes en el Impasse. In: Conversaciones en el Impasse: Dilemas Políticos del Presente. Buenos Aires, Tinta Limón Ediciones, 2009.

Epílogo. In: GAC: Pensamientos, Practicas, Acciones. Buenos Aires, Tinta Limón Ediciones, 2009 b.

Epílogo/Notas sobre la noción de "comunidad" a proposito de Dispersar el Poder. Los movimientos como poderes antiestatales. In: Zibechi, Raúl. Dispersar el poder. Los movimientos como poderes antiestatales. Buenos Aires, Tinta Limón Ediciones, 2006.

19 y 20: Apuntes para el nueno protagonismo social. Buenos Aires, Ediciones de Mano en Mano, 2002.

Colectivo Situaciones e MTD Solano. Hipóteses 891. Buenos Aires, Ediciones de Mano en Mano, 2002.

Das, Veena e Poole, Debora. El estado y sus márgenes. Etnografias Comparadas. Cuadernos de Antropología Social $n^{\circ} 27,2008$. Santa Fe, SAR Press, 2004 (on line).

Da Matta, Roberto. A mensagem das festas: reflexões em torno do sistema ritual e da identidade brasileira. In: Revista Sexta Feira (Antropologia, Artes e Humanidades), nº 2, São Paulo, 1998.

O ofício do etnólogo ou como ter antropological blues. In:

Nunes, Edson (org). A aventura sociológica. Rio de Janeiro, Zahar, 1978.

Debord, Guy. A Sociedade do Espetáculo: comentários sobre a sociedade 
do espetáculo. Tradução Estela dos Santos Abreu. Rio de Janeiro, Contraponto, 2005.

Deleuze, Gilles \& Guattari, Félix. Mil platôs: capitalismo e esquizofrenia, Vol. 1. Tradução Ana Lúcia de Oliveira, Aurélio Guerra Neto e Célia Pinto Costa. São Paulo, Ed. 34, 2004.

Deleuze, Gilles \& Guattari, Félix. Mil Platôs: capitalismo e esquizofrenia, Vol. 5. Tradução de Peter Pál Pelbart e Janice Caiafa. São Paulo: Ed. 34, 2005.

Deleuze, Gilles. En Medio de Spinoza. Tradução equipe editorial Cactus. Buenos Aires, Editoral Cactus, 2004.

Deutshe, Rosalyn. Art and Spatial Politics. Cambridge/Londres, MIT Press, 1996.

Domingues da Silva, Telma. A catraca, o pedestal e a praça: no espaço urbano, entre a realização do sentido artístico e a mídia. In: Revista Rua. Campinas, LabeUrb Unicamp, 2006.

Expósito, Marcelo. Entrar y salir de la institución: autovalorización y montaje en el arte contemporáneo, 2006. In: http://eipcp.net/transversal/0407/exposito/es, acessado em junho de 2012.

Ferguson, James e Gupta, Akhil. Spatializing states: toward an ethnography of neoliberal governmentality. In: American Ethnologist vol. 29 (4). American Anthropological Association, 2002.

Ferrari, Florencia O mundo passa. Uma etnografia dos calon e suas relações com os brasileiros. Tese de Doutorado em Antropologia Social. Faculdade de Filosofia, Letras e Ciências Humanas, Programa de Pós-graduação em Antropologia Social, Universidade de São Paulo, 2010.

Ferreira, Edemar Cid. Um feito único. In: Brasil +500: Mostra do Redescobrimento. Fundação Bienal de São Paulo - São Paulo e Associação Brasil 500 Anos Artes Visuais, 2000.

Fonseca, Felipe. Um Resumo do Brasil Profundo In: http://culturadigital.br/redelabs/2010/06/um-resumo-do-brasil-profundo, acessado em abril de 2012.

Foucault, Michel. De Outros Espaços. Conferência proferida pelo autor no Cercle d'Études Architecturales em 14 de março de 1967 e publicada em Architecture, Movement, Continuité 5, em 1984. Tradução Pedro Moura. Disponível em http://www.virose.pt/vector/periferia/foucault_pt.html, acessado em maio de 2012.

Foucault, Michel. Vigiar e Punir: História da Violência nas Prisões. Tradução Raquel Ramalhete. Petrópolis, Vozes, 1997. 
GAC. GAC (Pensamientos, Practicas, Acciones). Buenos Aires, Tinta Limón Ediciones, 2009.

. Pensamientos Cartográficos. In: Catálogo da exposição ExArgentina: Pasos para Huír del Trabajo al Hacer (Alice Creischer, Andreas Siekmann e Gabriela Massuh - eds.). Colonia/Buenos Aires, Interzona/Goethe Institut, 2004.

Galindo, Maria e Sánchez, Sonia. Ninguna Mujer Nace para Puta. Buenos Aires, Lavaca Editora, 2007.

Geertz, Clifford. A Interpretação das Culturas. Rio de Janeiro, Editora Guanabara Koogan, 1989.

Gil, Gilberto. Entrevista cedida à Gegê Produções. Rio de Janeiro, 2010. Link para assistir vídeo em http://www.producaocultural.org.br/slider/gilberto-gil/ acessado em abril de 2012.

Grossmann, Martin. Museu como Interface, 2011. In: Fórum Permanente (online). Link: http://www.forumpermanente.org/.event_pres/simp_sem/padped0/documentacao-f/mesa_03/mesa3_martin/, acessado em junho de 2012.

Guattari, Felix e Rolnik, Suely. Cartografias do Desejo. Petrópolis, Editora Vozes, 2005.

Habermas, Juergen. Arquitetura Moderna e Pós-Moderna. In: Um Ponto Cego no Projeto Estético de Juergen Habermas: Arquitetura e Dimensão Estética depois das Vanguardas (org. Otilia Beatriz Fiori Arantes e Paulo Eduardo Arantes). Tradução Bento Itamar Borges. São Paulo, Brasiliense, 1992.

Habermas, Juergen. Mudança Estrutural da Esfera Pública. Tradução Flávio R. Kothe. Rio de Janeiro, Tempo Brasileiro, 2003.

Hardt, Michael e Negri, Antonio. Multidão: Guerra e Democracia na Era do Império. Tradução: Clóvis Marques. São Paulo, Editora Record, 2005.

Harvey, David. A liberdade da cidade. Tradução Gavin Adams. In: Urbânia 3. São Paulo, Editora Pressa, 2008.

Heller, Agnes. O cotidiano e a história. Tradução Carlos Nelson Coutinho e Leandro Konder. Rio de Janeiro, Editora Paz e Terra, 2004.

Holmes, Brian. L'extradisciplinaire. Vers une nouvelle critique Institutionnelle, Multitude $\mathbf{n}^{\circ}$ 28. Paris, 2007.

Huyssen, Andreas. Mapeando o Pós-Moderno. In: Pós-Modernismo e Política (org. Heloisa Buarque de Holanda). Rio de Janeiro, Rocco, 1991.

Jameson, Fredric. Pós-Modernidade e Sociedade de Consumo. Tradução Vini- 
cius Dantas. In: Novos Estudos CEBRAP n 12, São Paulo, 1985.

José, Beatriz Kara. Políticas Culturais e Negócios Urbanos: a instrumentalização da cultura na revalorização do centro de São Paulo (1975-2000). São Paulo, Annablume/ Fapesp, 2007.

Lazzarato, Maurizio. Politicas del acontecimiento. Tradução Pablo Esteban Rodríguez. Buenos Aires, Tinta Limón Ediciones, 2006.

Lefebvre, Henri. A Revolução Urbana. Tradução Sérgio Martins. Belo Horizonte, Editora UFMG, 1999.

. La Production de L’Espace. Paris, Éditions Antropos, 1981. (Leitura da tradução livre em português).

Moraes, 1991.

O direito à cidade. Tradução Rubens Frias. São Paulo, Ed.

O Fim da História. Tradução Antonio Reis. Lisboa, Publicações Dom Quixote, 1971.

Levitt, Peggy e Glick Schiller, Nina. Conceptualizing Simultaneity: A Transnational Social Field Perspective on Society. International Migration Review, Volume 38 Number 3, 2004.

Martins, José de Souza. As temporalidades da história na dialética de Lefebvre. In: Henri Lefebvre e o retorno à dialética. São Paulo, Hucitec, 1996.

O senso comum e a vida cotidiana. In: A Sociabilidade do Homem Simples. São Paulo, Hucitec, 2000.

Henri Lefebvre e o retorno à dialética. São Paulo,

Hucitec, 1996.

Marx \& Engels, Coleção Grandes Cientistas Sociais (org. Florestan Fernandes). São Paulo, Editora Ática, 1989.

Mesquita, André. Insurgências Poéticas: Arte Ativista e Ação Coletiva. São Paulo, Annablume/Fapesp, 2011.

Mesquita, Ivo. Apresentação. In: Catálogo do Panorama 2001. São Paulo, Museu de Arte Moderna, 2001.

Misse, Michel. O Rio como bazar: a conversão da ilegalidade em mercadoria politica. In: Insight Inteligência, v. 3, n. 5, 2002. On line: http://www.insightinteligencia.com.br/56/, acessado em junho de 2012.

As ligações perigosas: mercado informal ilegal, narcotráfico e violência no Rio. In: Contemporaneidade e Educação, v. 1, n. 2, Rio de Janeiro, 1997. 
Mujeres Creando. La Virgen de los Deseos. Buenos Aires, Tinta Limón Ediciones, 2005.

Negri, Toni; Mattini, Luis; Benasayag, Miguel; Colectivo Situaciones; Gonzalez, Horacio; Holloway, John e Brand, Ulrich. Contrapoder: una introduccion. Buenos Aires, Ediciones de Mano en Mano, 2001.

Oseki, Hajime Jorge. O único e o homogêneo na produção do espaço. In: Henri Lefebvre e o Retorno à Dialética (org. José de Souza Martins). São Paulo, Hucitec, 1996.

Pallamin, Vera M. Invertendo Expectativas, texto apresentado no I Simpósio de Estética - Temas em torno da arte contemporânea na Pontifícia Universidade Católica de São Paulo, 2010.

Do lugar-comum ao espaço incisivo: dobras do gesto estético no espaço urbano. In: Espaço e Performance (org. Maria Beatriz Medeiros e Marianna Monteiro). Brasília, Editora da pós-graduação em Arte da Universidade de Brasília, 2007.

Arte Pública como Prática Crítica. In: Cidade e Cultura: esfera pública e transformação urbana (org. Vera M. Pallamin). São Paulo, Editora Estação Liberdade, 2002.

Arte Urbana: São Paulo: Região Central (1945-1988): obras de caráter temporária e permanente. São Paulo, Annablume/Fapesp, 2000.

Park, Robert. On Social Control and Collective Behavior. Chicago University Press, 1967.

Ranciére, Jacques. O Espectador Emancipado. Tradução José Miranda Justo. Lisboa, Orfeu Negro, 2010.

Será que arte resiste a alguma coisa? Tradução de Mônica Costa Neto. Disponível em: http://www.rizoma.net/interna.php?id=316\&secao=artefato, acessado em março de 2011.

A partilha do sensível: estética e política. Tradução Mônica Costa Netto. São Paulo, ED.34/EXO, 2005.

ROY, Ananya. The 21st Century Metropolis. New geographies of theory. Regional Studies, v.43, 2009.

ROY, Ananya. Urban informality: toward an epistemology of planning. Journal of the American Planning Association, 2005.

Rolnik, Suely. Cartografia Sentimental: Transformações Contemporâneas 
do Desejo. São Paulo, Estação Liberdade, 1989.

Geopolítica da Cafetinagem, 2006. Publicado em http://www.pucsp.br/nucleodesubjetividade/Textos/SUELY/Geopolitica.pdf, acessado em junho de 2012.

Memória do Corpo Contamina Museu, 2007. Publicado em http://eipcp.net/transversal/0507/rolnik/pt, acessado em junho de 2012.

Santos, Eufrázia Cristina Menezes. Gilroy, Paul. O Atlântico Negro: modernidade e dupla consciência. Rev. Antropol. [online], vol.45, n.1, 2002.

Schiller, Nina Glick e Wimmer, Andreas. Methodological Nationalism and Beyond. Nation-State Building, Migration and the Social Sciences. Global Networks, 2-4, 2003.

Simmel, Georg. A metrópole e a Vida Mental. In: O Fenômeno Urbano (org. Otávio Velho). Rio de Janeiro, Zahar Editores, 1967.

Tarrius, Alain. La mondialisation par le bas: les nouveaux nomades de l'economie souterraine. Paris, Balland, 2002.

Telles, Vera. Ilegalismos urbanos e a Cidade. In: Novos Estudos, Cebrap, n 84, 2009.

Telles, Vera. Nas dobras do legal e ilegal: ilegalismos e jogos de poder. Revista Dilemas, $n^{\circ}$ 5-6, 2009.

Themudo, Tiago Seixas. Gabriel Tarde - Sociologia e Subjetividade. Rio de Janeiro, Relume Dumará, 2002.

Topalov, Cristian. Os saberes da cidade em crise. Revista Espaço e Debates,

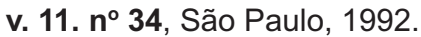

Vianna, Hermano. O Atlântico Negro, 1999. Rizoma.net/Afrofuturismo (on line). Link: http://pt.scribd.com/doc/46875356/Afrofuturismo-Rizoma-net, acessado em abril de 2012.

Virno, Paolo. Ambivalecia de la multitud: entre la innovación y la negatividad. Tradução Emilio Sadier e Diego Picotto. Buenos Aires, Tinta Limón Ediciones, 2006

O cérebro social como interação direta entre sujeitos de carne e osso. In: IHU ON-LINE. São Leopoldo, 2005, ano IV, n. 161.

Zourabichvili, François. O Vocabulário de Deleuze. Tradução André Telles. Rio de Janeiro, digitalização e disponibilização da versão eletrônica: IFCH-UNICAMP, 2004. 


\section{Catálogos, Periódicos, Publicações autônomas dos Coleti- vos, Sites, Materiais não publicados}

Blog do $\quad$ Grupo de $\quad$ Arte Callejero. Link:
http://grupodeartecallejero.blogspot.com.br, acessado em junho de 2012.

Catálogo da Exposição Colletive Creativity. Kunsthalle Fridericianum Museum, Kassel, Alemanha, 2005.

Catálogo-jornal da exposição If You See Something, Say Something. Mori Gallery, Gallery 4A, Chrissie Cotter Galery, Sydney, Austrália, 2007.

Catálogo da Exposição La Normalidad/Ex-Argentina. Museu Palais de Glace, Buenos Aires, Argentina, 2006.

Catálogo da exposição: Lygia Clark: da obra ao acontecimento. Nós somos o molde. A você cabe o sopro. Pinacoteca do Estado de São Paulo e Musée des Beaux-Arts de Nantes, São Paulo, 2005-2006.

Catálogo-jornal da exposição Strategies of Self Education. Centro Nacional de Arte Contemporânea de Moscou, Rússia, 2006.

Catálogo do Panorama da Arte Brasileira 2001. Museu de Arte Moderna de São Paulo, São Paulo, 2001.

Conversa entre Franco Berardi e diversos coletivos na rádio autônoma La Tribu de Buenos Aires, Argentina, dia 9 de novembro de 2007.

Contrafilé. A Rebelião das Crianças. Publicação fomentada pelo Programa de Valorização de Iniciativas Culturais (VAI), São Paulo, 2007.

Espai en Blan. Materiales para la subversión de la vida. Barcelona, Ediciones Bellterra, 2007.

Frente 3 de Fevereiro. Cartografia do Racismo para o Jovem Urbano. São Paulo, Programa de Valorização de Iniciativas Culturais (VAI), São Paulo, 2007.

Livro-obra do Panorama da Arte Brasileira 2001. Museu de Arte Moderna de São Paulo, São Paulo, 2001.

Política do Impossível. Cidade dos Cartógrafos. São Paulo, Oficina Cultural Oswald de Andrade, 2006. 
Política do Impossível. Cidade Luz: uma investigação-ação no centro de São Paulo. Edital Conexão Artes Visuais, 2008.

Revista Brumaria. Editores: Darío Corbeira e Marcelo Expósito, Associon Cultural Brumaria, Madrid, Espanha. Todos os números (1 a 8).

Fórum Permanente. Link: http://www.forumpermanente.org, acessado em junho de 2012.

Portal do SESC. Link: http://www.sescsp.org.br/sesc/, acessado em junho de 2012.

Revista Urbânia, Editora Responsável: Graziela Kunsh, Editora Pressa, São Paulo, 2008.

Revista Parachute 116 (São Paulo). Editora: Suely Rolnik, Montreal, Canadá, 2003.

Site do Museo Reina Sofía. Link: http://www.museoreinasofia.es/index.html

Rizoma.net, publicação virtual, editores Ricardo Rosas e Marcus Salgado. Link: http://www.intervencaourbana.org/rizoma/rizoma_afrofuturismo.pdf 


\section{LISTA DE IMAGENS}

CAPA:

Monumento à Catraca Invisível, Contrafilé, São Paulo, 2004.

EPIGRAFE:

p. 18: Egito, 2011. Khaled Elfiqi/European Pressphoto Agency.

INTRODUÇÃO:

p. 35: Imagens cedidas por Suely Rolnik, parte de sua apresentação "Para além do inconsciente colonial”, concepção Suely Rolnik, execução Bijari.

CAPITULO 1:

p. 53: Imagens do MICO das frases na rua "Chega de Mickey, 500 anos de Mico" e "Chega de Bananalização, 500 anos de Mico" e do Monumento às Bandeiras coberto com cobertores, MICO, 2000. Foto: acervo MICO.

p. 59: Imagem do MICO em ação no Vale do Anhangabaú, MICO, 2001. Foto: acervo MICO.

p. 61: Notas de dinheiro carimbadas pelo MICO, 2000. Fotos: Peetssa.

p. 63: Docentes Ayunando, GAC, 1997. Fotos: acervo GAC.

p. 65-71: Ação Direta. Homenagem aos Assassinados pela Repressão Policial na Rebelião Popular de 20 de dezembro de 2001, GAC. Fotos: acervo GAC.

p. 74-77: Jornais que mostram imagens de rebeliões em presídios de São Paulo, 2001. Fotos: Peetssa.

p. 80: Imagem dos integrantes do MICO pintando a frase "Não Estamos em Rebelião..", 2001. Foto: acervo MICO.

p. 81-83: Imagens de jornais que mostram repercussão do deslocamento da frase pelo MICO, 2001. Foto: Peetssa.

p. 84-85: Faixa com a frase “Não Estamos em Rebelião..." pintada de preto, 2001. Foto: acervo MICO.

p. 86: Trabalho apresentado na exposição "If You See Something, Say Something", que aconteceu na Austrália em fevereiro de 2007. Foto: Peetssa.

p. 87: Trabalho do Contrafilé na Skuc Galerija. Ljubljana, Eslovênia, 2008. Foto: Peetssa.

p. 88: Imagem da sistematização feita pelo Contrafilé do trabalho do MICO utilizando a frase "Não estamos em Rebelião". Foto: Peetssa.

p. 94-95: Imagens do trabalho Corda do Contrafilé e de sua instalação, Festival Mídia Tática Brasil, São Paulo, 2003. Foto: acervo Contrafilé. 
p. 100-101: Cartografias feitas pelos coletivos Política do Impossível, Frente 3 de Fevereiro, Bureau d'études e Bijari.

p. 106-109: Imagem da cartografia Aquí Viven Genocidas, 2001, GAC. Fotos: acervo GAC.

p. 111-113: Seqüências de jornais sobre as rebeliões na FEBEM. Fotos: acervo Contrafilé.

p. 114-115: Imagens do trabalho A Rebelião das Crianças, Contrafilé, 2005. Fotos: Peetssa.

p. 116-119: Parque para Brincar e Pensar, realizado pelo Contrafilé, Comunidade Brás de Abreu e Jardim Miriam Arte Clube (JAMAC, atelier-escola da artista Mônica Nador localizado no Jardim Miriam), São Paulo, 2011. Fotos: acervo Contrafilé.

p. 134-137: Imagens da publicação “Cidade Luz", PI, 2008. Fotos: acervo PI.

p. 145-151: Imagens do trabalho Blancos Móviles, GAC. Fotos: acervo GAC.

\section{CAPITULO 2}

p.166-167: Placa feita pelo PI mudando o nome da Av. Bandeirantes para Av. dos Quilombolas, São Paulo, 2008. Fotos: acervo PI.

p. 168-169: Trabalhos que usam códigos oficiais, modificando-os. Fotos: respectivamente Centro de Mídia Independente, acervo Jerusa Messina e acervo PI.

p. 172-175: Imagens do trabalho Invasion do GAC, 2001. Fotos: acervo GAC.

p. 178-183: Imagens dos Escraches e dos trabalhos do GAC feitos nessa situação. Fotos: acervo GAC.

p. 199: Imagem slogan prefeitura Marta Suplicy, 2004.

p. 199: Slogan “Programa para Descatracalização da Própria Vida”, Contrafilé, 2004.

p. 200: Assembléia de Olhares sobre o "Programa para Descatracalização da Própria Vida" com lideranças locais da zona leste de São Paulo, junho de 2004. Foto: Peetssa.

p. 202: Imagem anatomia exterior de uma catraca, Contrafilé, 2004.

p. 204: Imagem da instalação da catraca pelo Contrafilé. Largo do Arouche, São Paulo, junho de 2004. Foto: acervo Contrafilé.

p. 205: Monumento à Catraca Invisível. Largo do Arouche, São Paulo, junho de 2004. Foto: acervo Contrafilé.

p. 208: Folha de São Paulo, Caderno Cotidiano, 4 de setembro de 2004.

p. 211: Imagens tiras Laerte, Folha de São Paulo, setembro de 2004 a fevereiro de 2005.

p. 212: O Estado de São Paulo, 10 de janeiro de 2005.

p. 212: Folha de São Paulo, 10 de janeiro de 2005.

p. 215: Folha de São Paulo, 10 de janeiro de 2005. 
p. 216: Folha de São Paulo, 11 de fevereiro de 2005.

p. 217: Imagem produzida pelo Movimento pelo Passe Livre, 2006.

p. 218: 40. Folha de São Paulo, 11 de janeiro de 2005.

p. 219: Folha de São Paulo, 17 de janeiro de 2005.

p. 220-221: Cartazes do "Programa para Descatracalização da Própria Vida", Contrafilé, 2005. Fotos: acervo Contrafilé.

p. 222: Sistematização feita pelo Contrafilé com o intuito de refletir sobre o que sucedeu no "Programa para Destracalização da Própria Vida", apresentada na Collective Criativity, Friedericianum Museum, 2005.

p. 223-225: "Programa para Descatracalização da Própria Vida" apresentado como obrasistematização de um processo em diferentes exposições ao redor do mundo: Collective Criativity (Alemanha/Kassel, 2005), La Normalidad (Buenos Aires/Argentina, 2006) e If you See Something, Say Something (Sidney/Austrália, 2007).

\section{CAPITULO 3}

p. 244-245: Imagens do trabalho do grupo MICO para o Panorama, 2001. Fotos: acervo MICO.

p. 248: 1o CIA (Congresso Internacional de Ar(r)ivismo, realizado em São Paulo em 2003. Foto: acervo Daniel Lima.

p. 253: Trabalho do GAC na 50o Bienal de Veneza, Veneza, Itália, 2003. Foto: acervo GAC.

p. 254: Trabalho da Frente 3 de Fevereiro na exposição La Normalidad, Buenos Aires, Argentina, 2006. Foto: Peetssa.

p. 256-257: Contrafilé e Bijari no Seminário Arte, Estética e Política Urbana: Pensamentos e Práticas Artísticas e Sociais no Espaço Público da América Latina, no Centro Cultural da Espanha, Santiago, Chile, 2009. Fotos: Peetssa.

p. 262-267: Jogo do Absurdo Público, PI, entre 2005 e 2011. Fotos: acervo PI.

CAPITULO 4

p. 268: Instalação dos ponteiros de relógio em Rotterdam e a intervenção já realizada, Contrafilé, 2003. Foto: Peetssa.

p. 282-283: Imagens: Brasil Negro Salva, Onde Estão os Negros? e Zumbi Somos Nós em Estádios e no Edifício Prestes Maia, 2004-2006. Fotos: Frente 3 de Fevereiro e Peetssa.

p. 286-287: Projeto “Quilombo Brasil”, PI, 2008-2010. Fotos: acervo PI.

p. 293: Conversa entre Conceição Paganele, Maurinete Lima e TC no alto da ocupação Mauá, São Paulo, 2008. Fotos: acervo PI.

p. 298-299: Show da Frente 3 de Fevereiro, CEU Casablanca, 2006. Fotos: Peetssa.

p. 302-303: Monumento Horizontal à Flávio Sant'Ana, Frente 3 de Fevereiro, São Paulo, 2004. Fotos: acervo Frente. 
p. 304: Imagens do workshop proposto pela Frente para outros coletivos de Berlim, Alemanha, 2006. Fotos: acervo Frente.

p. 305: Frente 3 de Fevereiro em Berlim, 2006. Fotos: acervo Frente.

p. 307: Bandeira feita pela Frente 3 de Fevereiro e coletivos de Berlim e aberta na festa de abertura da Copa do Mundo de 2006, Berlim, Alemanha. Foto: acervo Frente.

p. 308: Intervenção através do som de tambores do músico DouDou N'diaye Rose e sua orquestra na llha de Gore. Frame do vídeo

p. 311: Intervenção do PI, Casa de Cultura Tainá, Jongo Dito Ribeiro entre outros, na Fazenda Jambeiro, Campinas, 2007. Fotos: acervo PI.

p. 313: Conversa entre diversos grupos e o músico africano DouDou N’diaye Rose, 2007, Belo Horizonte. Fotos: Cássio Martins. 


\section{Revisão:}

Lia Zatz

Pesquisa de Imagens:

Daniel Lima / Joana Zatz

\section{Projeto Gráfico:}

Daniel Lima

2012 